\title{
OCEAN RESEARCH AND THE
}

GREAT FISHERIES 



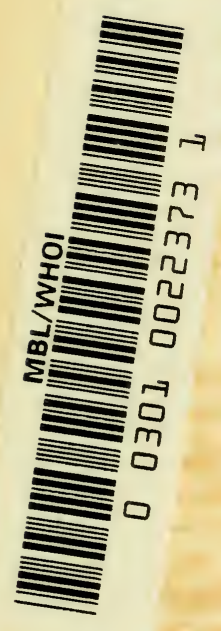





\section{OCEAN RESEARCH}

AND THE GREAT FISHERIES 


\section{OXFORD UNIVERSITY PRESS}

London Edinburgh Glasgow Copenhagen

New York Toronto Melbourne Cape Town

Bombay Calcutta Madras Shanghai

HUMPHREY MILFORD

Publisher to the University 


\section{OCEAN}

\section{RESEARCH}

\section{AND}

\section{THE GREAT FISHERIES}

BY

G. C. L. HOWELL, M.A.

INDIAN CIVIL SEHVICE (RETIRED)

ACTING SECRETARY BRITISH FISHERIES SOCIETY

FORMERLY DIRECTOR OF FISHERIES, PaNJáb

O X F O R D

A'T THE CLARENDON PRESS

1921 

DEDICATED TO ALL

WHO OCCUPY THEIR BUSINESS

IN GREAT WATERS 



\section{PREFACE}

I could not have attempted to write this book for the British Fisheries Society if I had not had Dr. 'Travis Jenkins' The Sea Fisheries, Dr. Meek's Migrations of Fish, Dr. McIntosh and Dr. Masterman's British Marine Food Fishes, Dr. James Johnstone's British Fisheries, and Dr. Fowler's Science of the Sea on my table. To their authors I owe more than I can express. But above all I am indebted to Dr. Hjort, whose chapters in The Depths of the Ocean are an inexhaustible mine of information. This book, such as it is, is chiefly an expansion of many notebooks - the sort. of notes which every District Officer in the India which has passed was wont to make about the things which were his business, all through his service. They taught him, unless he metamorphosed into an habitual Secretary to Government, that he knew nothing.

Let me thank the civil servants who prepared the Annual Fishery Reports of the Board of Agriculture and Fisheries, and the Fishery Board for Scotland and the Irish Department of Agriculture. My copies of their statistical tables have been thumbed to the point of disintegration-a happy fate which seldom overtakes blue books. Professor James Johnstone has acted not only as illustratur but as editor, and Dr. Hjort has kindly allowed me to use several illustrations from his works.

Finally my thanks are due to Dr. M. V. Lebour, Mr. E. H. Havelock, Dr. E. J. Allen, Professor Garstang, Professor J. Stanley Gardiner, Professor Meek, Mr. G. Moody, Mr. B. 
Storrow, Mr. C. A. IV. Burgoyne, Mr. A. E. Hefford, Mr. A. J. Brander, Mr. R. B. Marston, Mr. J. A. Robertson, and my friend and colleague Mr. R. Jackson, who have each read all or part of the MS. and given me much advice, encouragement, and assistance. If I have anywhere appeared to borrow or steal ideas without acknowledgement I apologize here and now, and renounce all claim to the property. What is good in the book is the work of other people. The mistakes are my own.

G. C. L. HOWELI.

GADESPRINGS,

Hemel Hempstead.

August 1921. 


\section{CON'TEN'TS}

CHAPTER

PAGE

I. Introductory . . . . . . 13

II. The Great Fisheries . . . . . 17

III. The Organization of Ocean Research . . 21

IV. Statistics . . . . . . . 26

V. The Plaice Question . . . . . . 31

VI. The Life-History of the Plaice . . . 34

VII. The Stock of Plaice . . . . . 40

VIII. The Transplantation of Plaice . . . . 46

IX. Comparative Productivity of the Plaice Grounds . . . . . . . 51

X. Shrimping and Plaice . . . . . . 54

XI. Size Limits, \&c. $\quad$. $\quad$. $\quad$. $\quad$. $\quad$. 56

XII. The Apparent Effect of the War on Plaice . 62

XIII. The Turbot and 'I'urbot C'ulture . . . 65

XIV. The Soles . . . . . . . 71

XV. The Haddock Problem . . . . 76

XVI. Norwegian Haddock Investigation . . 84

XVII. The Corl . . . . . . 87

XVIII. The Coalfish or Saithe. . . . . 99

XIX. The Halibut . . . . . . 102

XX. The Hake Fisheries . . . . . 108

XXI. Business men on Hake Problems . . . . 116

XXII. Dr. Le Danois on the Hake . . . 122

XXIII. The Skates and Rays . . . . . 128

XXIV. The Ling . . . . . . 134

XXV. The Whiting . . . . . . 138

XXVI. Lemon Soles . . . . . . 143 
XXVII. The Herring Fisheries . . . . 151

XXVIII. Eggs and Fry of the Herring • • • 156

XXIX. Adult Herrings (Races and Scale Reading) . 163

XXX. International Herring Researches. • . 178

XXXI. The Mackerel . . . . . . 180

XXXII. The Small Game of the Sea . . . 186

Appendix I. 'The Position in 1920 . . . 198

Appendix II. Fluctuations 1906-20 . . . . 202

Appendix III Measurement of Fish Eggs . . . 207

Bibliography . . . . . . . . 208

INDEX $\quad . \quad . \quad . \quad . \quad . \quad . \quad 213$ 


\section{LIST OF ILLUSTRATIONS}

FIG

PAGE

1. Scales of coalfish of different ages and lengths . . . . . 2:3

2. Baby plaice . . . . . . . . . . 35

3. Marking experiments from Iceland showing that in the spring the mature plaice wander from colder waters (Vopnafiord and Skjalfandi Bay) to the southern and western shores in order to find suitable spawning conditions . . . . . . 42

4. The small-plaice grounds . . . . . . . . 57

5. Apparatus for hatching turbot . . . . . . 67

6. Development of the cod . . . . . . . . 91

7. Relative numbers of coalfish and cod at the stage when the fish cease to float at the surface with the current, and take to the bottom . . . . . . . . 101

8. Baby halibut $\frac{9}{10}$ inch long . . . . . . . 105

9. Newly hatched hake $\frac{1}{10}$ inch long . . . . . . . 125

10. Baby hake $0 \cdot 17$ inch $(4.5 \mathrm{~mm}$.) long . . . . . . 125

11. Hake fry, $\frac{5}{8}$ inch long . . . . . . . . $\quad$. 125

12. Development of the ray . . . . . . . 131

13. Egg of ling . . . . . . . . . . . . 136

14. Ling fry $\frac{9}{10}$ inch long . . . . . . . . . 136

15. Baby whiting $0 \cdot 16(4.3 \mathrm{~mm}$.) long . . . . . . . 141

16. Baby lemon sole 0.25 inch $(6.5 \mathrm{~mm}$.) long _ . . . . 146

17. Lemon soles . . . . . . . . 148

18. Baby herrings . . . . . . . . 161

19. Scales of herring . . . . . . . . . 168

20. Temperature of the North Atlantic at a depth of 55 fathoms . 187

21. Currents of the North Atlantic . . . • . . 188

22. Surface temperature of the North Atlantic, February and August 189

23. Surface temperature of the North Sea in August . . 190

24. Surface temperature of the North Sea in February . . . 190

25. Cladocera or water fleas $\quad . \quad . \quad . \quad . \quad . \quad . \quad . \quad 194$

26. Sunshine and mackerel . . . . . . . . . 197 


\section{LIST OF PLATES}

PLATE

I. Steam trawling: (1) The net slung up; (2) Shooting the gear

II. Steam trawling: (1) The net alongside in rough weather :

(2) The eatch on reck . . . . . . 201

III. Common Sole . . . . . . . . . 72

[V. 'Temora . . . . . . . . . 74

V. Haddock . . . . . . . . . 80

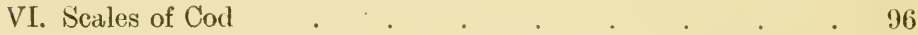

VII. Coalfish . . . . . . . . . 100

VIII. Halibut Otolith . . . . . . . . 104

IX. Hake . . . . . . . . . . 120

X. Skate . . . . . . . . . . . . 128

XI. Ling . . . . . . . . . 136

XII. Young Fish . . . . . . . . . 140

XIII. Lemon Sole . . . . . . . . . 144

XIV. Scales of Lemon Soles . . . . . . . . 148

XV. Herring Eggs on Seaweed . . . . . . 1.56

XVI. Scales of Herring . . . . . . . . 168

XVII. Podon (Water Flea) . . . . . . . 182

XVIII. Plankton containing Fish Eggs . . . . . . 192

XIX. Barnacles . . . . . . . . 194

XX. (1) Schizopods or 'Splitfoot'Shrimps; (2) Copepods (C'alunus);

(3) Amphipods or Sand-hoppers . . . . . 196

\section{LIST OF MAPS}

(at end of book)

No. I. General Map of the Great Fisheries.

No. II. Sketch Map of the North Sea.

No. III. Sketch Map of the Northern Herring Grounds. 


\section{CHAPTER I}

\section{INTRODUCTORY}

\section{OCEAN RESEARCH AND THE GREAT FISHERIES}

Two years ago the writer had very vague ideas indeed about research work as applied to the fisheries. A kind fortune has, since that time, brought him to some extent into contact with marine investigators and also with the fishing brotherhood. He has had nothing but pleasure out of this intercourse, but it taught him that some naturalists in this country are not fully in touch with the economics of fishing; and that the industry is, in its turn, not generally acquainted with the men to whose researches it is more deeply indebted than it knows. For his own education he has delved, laboriously and unhandily as an amateur will, into the biology and economics of fishery. The notes which follow were originally compiled as part of a course of self-instruction. With all diffidence they are now published for the expert criticism of Science on the one hand and Business on the other. If they induce Business and Science to talk things over with each other they will have served their purpose. Science is, sometimes, apt to regard the business man as a person 'who does not try to understand us' : Business may retort that Science 'never finds out anything useful', and so forth. The real fact is that there are two circles of extremely able and energetic men; each is intent on the work which lies to its hand; each, generally speaking, is too preoccupied with that work to spare time to explain its ideas and difficulties to comparative strangers ; and each uses a technical language of its own. The Great Fisheries are a young Industry ; Ocean Research is a young Science; and Youth is generally reticent about its enthusiasms until it is assured of sympathy. There are, however, signs that advancing age is producing (as always) a mutual desire for the exchange of ideas with people outside the immediate circle of the initiated.

In the pages which follow, the writer has attempted to give a picture of the fisheries as they were in 1913 - the last year for which normal statistics are available.

As he has studied-especially the works of Hjort-it has been borne in upon him more and more vividly that oceanic 
conditions - and particularly (it may be) the advance and retreat of the polar ice-may have very much more influence on the fluctuations in the catch of fishes of all kinds than any other factor ; and that fishery research is fundamentally an 'ocean' investigation. He has tried also to show that the Industry has been (and is) alive to the need for continuous and systematic inquiry into these conditions.

He started with the intention of confining his notes to the more 'important' species caught by British deep-sea vessels. To that end he made the following table. In his view the 'importance' of a fish-especially at this juncture-should be gauged by the amount of food which it provides. But it is of course arguable that the species should be ranged in order of the money which they bring to the producer, and in the table he has thus listed them. Well-to-do readers will find that their personal acquaintanceship with 'British' fishes is confined largely to species which bulk small, but sell well. Few of them, for instance, would recognize a ling or a coalfish, yet these two fishes are -as the figures show - of real 'importance' to the consumer. Very few people indeed have any idea of the interest attached to the founding of the great deep sea hake ${ }^{1}$ fishery in 1903 and its subsequent development.

The Comparative Talue of British Food Fishes (1913).

\begin{tabular}{lrrrrr} 
& \multicolumn{1}{c}{$\begin{array}{c}\text { Value. } \\
£\end{array}$} & $\begin{array}{c}\text { Quantity. } \\
\text { Tons. }\end{array}$ & & $\begin{array}{c}\text { Vulue. } \\
£\end{array}$ & $\begin{array}{c}\text { Quantity. } \\
\text { Tons. }\end{array}$ \\
1. Herring & $4,572,957$ & 611,000 & 14. Coalfish & 196,616 & 39,000 \\
2. Cod & $2,300,119$ & 200,000 & 15. Dabs & 104,473 & 5,800 \\
3. Haddock & $1,891,005$ & 115,000 & 16. Megrims & 86,002 & 4,600 \\
4. Plaice & $1,095,384$ & 37,000 & 17. Witches & 76,714 & 3,300 \\
5. Hake & 678,981 & 32,000 & 18. Brill & 73,237 & 1,000 \\
6. Soles & 480,254 & 3,400 & 19. Catfish & 68,828 & 9,500 \\
7. Halibut & 450,722 & 7,700 & 20. Conger & 53,752 & 4,000 \\
8. Whiting & 390,980 & 33,000 & 21. Gurnard & 35,097 & 5,500 \\
9. Turbot & 303,735 & 3,400 & 22. Bream & 28,527 & 5,000 \\
10. Skates & 292,972 & 25,000 & 23. Monks & 22,413 & 3,000 \\
11. Mackerel & 256,285 & 28,000 & 24. Pilehard & 21,865 & 2,500 \\
12. Lemon & & & 25. Dogfish & 20,242 & 3,200 \\
Soles & 245,912 & 4,800 & 26. Sprats & 19,721 & 5,400 \\
13. Ling & 198,405 & 21,000 & 27. Torsk & 18,418 & 2,400
\end{tabular}

To make this little book comprehensive it would be necessary to include notes upon the catches and the habits of all these commercial food fishes. But it lays no claim to be compre-

1 A redoubtable skipper, who had never before fished much below 80 fathoms, was blown out beyond the 100 fathom line one night by a north-easterly gale in July. Next morning, after going about, he found himself in 120 fathoms about 35 miles off the Kerry eoast. In desperation he shot his trawl, eaught quantities of hake, and continued to eatch them (in depths hitherto regarded as inaccessible) till (etober, all round the south of Ireland. 
hensive. Perhaps enough has been written to show the men who 'occupy their business in great waters '-trawlermen and drifter men alike - that men of science have already unravelled many of the secrets of the sea, and are in a fair way to unravel many more.

To indicate the immeasurable patience and endurance and self-sacrifice which these labours have involved, a quotation from the log of the Norwegian research vessel Michael Sars, off Jan Meyen on 16th February 1903, will suffice ${ }^{1}$ "The whole of the afternoon we were pretty well cased with ice-hull, spars, and standing rigging-and on running suddenly into the middle of an ice floe about nine o clock that erening we had a hard job to get the ship round against the wind, her sails being so stiff with ice that it was impossible to take them in.' It was practically night all the time and they were short of coal, but the work in hand was carried through, although " the stations we took up during the severe frosts were the reverse of easy, as the metre-wheels froze up, and we had to keep them warm with thick red-hot iron bars that were brought from the engineroom and held close to the wheel axles.'

Every Iceland trawlerman knows that that sort of thing is not 'yachting'. Aretic fishing is grim work. And these men had no comfort from hopes of good 'winter markets'. They were just investigating the habits of cod and haddock and coalfish. All honour to them. The Norsemen first showed us the way across the surface of the Atlantic before ever the mariner's compass was made, and it is fitting that they should lead us in the exploration of its depths. But it behoves ussurely-as our means admit-to follow that lead? The men and the spirit are ready to hand, but will the ships and the money be fortheoming?

In writing of the fishes the writer has used the word 'important', and, having done so, is doubtful whether the word has much meaning in connexion with Ocean Research. If this book fails to indicate a conviction that the study of diatomic plants so small as to pass through the meshes of the finest silk net, or of the larvae of such humble animals as the oar-footed copepods, the barnacles, the water fleas, the sandhoppers, and the sea-snails, is every bit as 'important' as observations on the halibut, or the herring, then it has been written in vain.

The future of fishery is probably bound up in an accurate knowledge of the needs and dangers of baby fish in the earliest and tenderest stages of their existence, and their world is a world which men can explore only with the aid of the microscope. ${ }^{2}$

${ }^{1}$ Hjort, Depths of Ocean, p. 54.

2 See Chapter xxxii. 
That belief is not at present shared by all the author's many friends in the fisheries. But is that not simply because Science, absorbed in its researches, and loathing 'advertisement', has not hitherto explained the situation in simple language'? No Fabre has, as yet, turned his attention to the ocean.

To the writer it seems that Science was in a position, years ago, to explode several old fallacies. For generations, for instance, driftermen have 'known' their 'interests' to be diametrically opposed to those of trawlermen; and that researches into the herring must be something quite distinct from those into trawl fish. Modern investigations have shattered this creed by showing that herrings, cod, and haddock are governed largely by the same influences in the-same year, and that these influences should all be studied as a single group. Has Science, again, ever explained that cod and haddock and ling and hake are among the herrings' most formidable enemies, so that every cod trawled may mean a few more thousand herrings in the gill nets ?

These two propositions properly stated and reiterated br naturalists in plain terms could, perhaps, have stopped much futile dissension in a house which cannot afford to be divided against itself. 


\section{CHAPTER II}

\section{THE GREAT FISHERIES}

Every one by this time knows that the country's supply of fish comes mainly from the high seas, and is brought to land by the deep-sea fishing fleets. Some few Britons now, at length, understand that there are two main fleets-the Drifter Fleet, which circumnavigates the coast, basing itself on different ports in succession, almost from year's end to year's end, in search of herrings; and the Trawler Fleet, which exploits the sea-bed for the 'white fish' who feed on the bottom. So much is understood. What is not, as a rule, made clear is that the Trawler Fleet is divided into several squadrons. Let us take them in order of seniority.

1. The South-Eastern Squadron. This is the lineal descendant of the old sailing fleet, and it fishes historic grounds developed in the middle of the last century by smacksmen under pioneer skippers and 'admirals'-more than one of whom has subsequently been the owner of a fleet of steam trawlers. A line between the Tees and the Skaw across the North Sea forms, roughly, the northern boundary of this squadron's 'sector'; the southern boundary is a line from the North Foreland to Grisnez; and east and west the squadron can fish up to the three-mile limit. It covers, therefore, the southern shallows of the North Sea, where the soundings run from 10 to 40 fathoms. These grounds were originally explored by men 'in sail' looking for soles, and they still produce nearly half the sole catch. But the squadron now depends mainly on haddock, cod, and plaice. Its English vessels caught some 98,000 tons in 1913. An average 'voyage' in April is somewhere in the neighbourhood of 14 tons.

2. The North-Eastern Squadron fishes that portion of the North Sea which lies to the north of the Tees-Skaw line inside the 100 -fathom limit, and its ground lies chiefly between the 30 and the 60-fathom line. The big haddock, cod, and plaice from the deeper banks form a large proportion of its catch. In 1913 the English catch was about 61,000 tons.

3. The Northern Deep-Sea Squadron is made up of the big powerful vessels who first found, and then worked, in 1891, the Iceland, Shetland, and Faeroe Banks for cod, haddock, coalfish, 
plaice, catfish, and halibut; raided the cod off Trondjhem; rounded North Cape, and raided the plaice and haddock and cod of the Barents Sea; felt out westward and fished the Rockall Bank and other banks between Iceland and Scotland, for haddock, ling, and cod. Their catch was about $134,000^{1}$ tons in 1913. An Iceland voyage averages about 68 tons in April.

4. The South-Western Deep-Sea Squadron. These men first learnt at the beginning of this century to trawl for the hake at 200 fathoms and over on the very edge of the coast banks. To haul their gear meant to wind up two miles of stout wire cable on their great winches. Thus equipped, they pioneered the hake and bream and skate fisheries right away (along the slopes running down to the abyss) from the south coast of Ireland through the Bay of Biscay to the southward. They only stopped their southward exploration because coral on the bottom makes trawling impossible south of the Canaries. They have clamoured to know whether marketable fish lived at 300 fathoms and lower on the slopes of the abyss. ${ }^{2}$ "If they are there,' they say, 'we will catch them.' They feel up to Rockall and the westward of Scotland also, where they overlap the Northern Squadron. In 1913, English ${ }^{1}$ vessels caught 75,000 tons.

5. The Western Squadron consists of smaller vessels who catch the soles, skates, and cod and plaice on the shallows between Ireland and the west coast of Wales and England, as their 'opposite numbers' on the south-east work the shallows of the North Sea. In 1913 English vessels caught 14,000 tons.

It is true that there is much overlapping of function among the 'staff officers '- the owners who direct these squadrons-and (to a lesser extent) among the executive officers who command their ships. But fishing, like most other crafts worth knowing, is a specialist's job. The first-class trawl skipper is a self-trained marine topographer who must know the sea-bed and the waters which cover it, and a great deal about the animals and plants which have their being on his hunting grounds. So most men specialize. A captain bound for Iceland, for instance, from the Humber will seldom shoot a trawl in the North Sea. And there leaps to the mind the case of an aged skipper who had asked for a ship and had been given a little North Sea trawler to fish during the war. He was told to take her into the North Sea, and refused-' I'm an Iceland man, I am.' So he went to

1 The Seottish statisties do not show the distribution of the Scottish trawlers orer these areas, so, for comparative purposes, the English eatehes only can be entered.

2 Hjort has answered this question. See p. 112. 


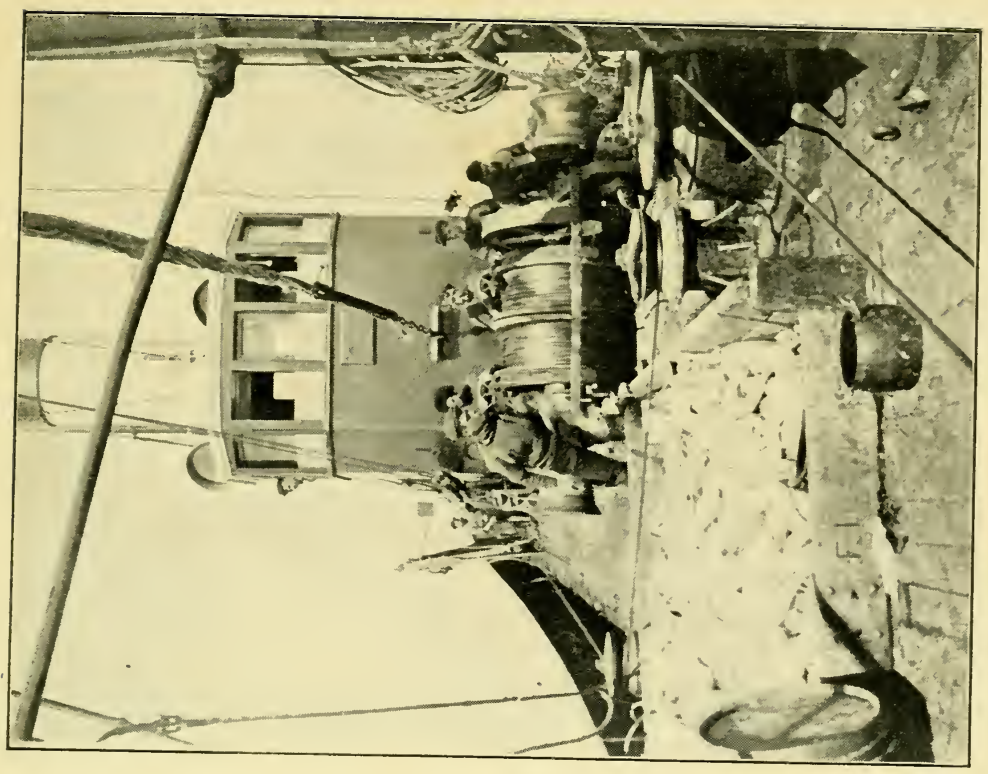

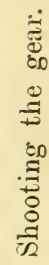

3
3
3
3
3

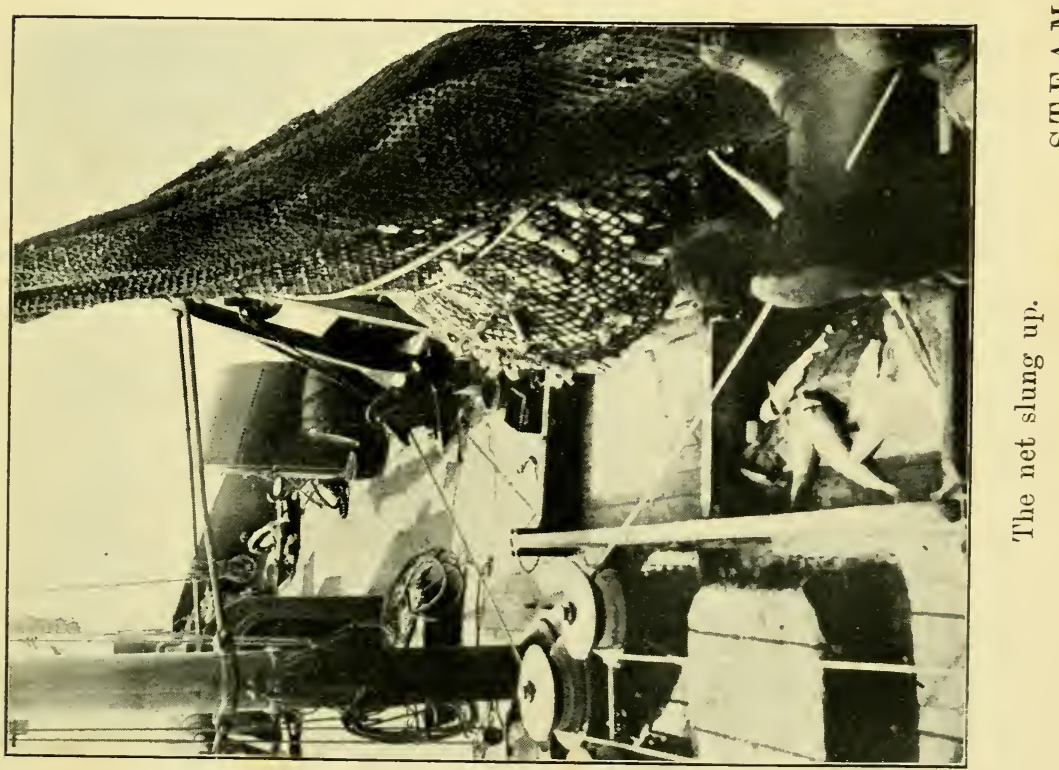



Iceland in very dirty weather and filled her with fish till her decks were awash. Incidentally he sank a U-boat, and (also incidentally) was badly holed and himself hit with shrapnel. He landed his fish, and won the D.S.C.

In the same way it is not as a rule sound business to transfer a ship from one squadron to another. North Sea work is quite a different proposition, financially as well as in other ways, from Iceland work or 'Hake' work. Under present conditions, a small trawler on the southern sole and plaice grounds, for instance, will just clear her expenses if she lands $£ 11,000$ worth of fish a year; but a deep-sea vessel will be in debt if she - grosses' less than $£ 22,000$. A ship is, in fact, the best machine for the work for which her class was designed. To put her on to other work would be no less injudicious than to order the Aquitania into the Bombay trade.

All this is laboured to show that each class of fishing is faced with problems which appear to fishermen to be; and are to some extent, distinct. A drifter man, who lands every day, a short voyage trawler who lands once every week or ten days ${ }^{1}$ or oftener, and the deep-sea man, all have questions to ask from naturalists, and all have sea lore to impart. Their main trouble is that they do not know how the work of exploring the ocean has been parcelled out, or the results which have already been achieved.

\section{Productivity of the Grounds}

The catch landed by the English fleets from the various regions demarcated in the chart in 1913 compared roughly as follows, and the species which prevailed in each region over the five years ending in 1912 are noted in the column of Remarks :

Tons in 1913.

Remarks

1. South of the North Sea 98,000

61,000

2. North of the North Sea

3. Iceland

Barents Sea $\quad 6,000$

Faeroe . . 32,000

North of Scotland $\quad$ - $\quad 3,800$

4. South of Ireland (1) . $\quad 31,000$

Westward of Ireland (3) $\quad 7,400$

Westward of Scotland (2) $\quad 30,900$

Rockall . . . 2,800

Bay of Biscay . $\quad$. 700

Portugal and Moroceo . 2,700

5. Irish Sea $\quad$. $\quad$ - 8,700

Bristol Channel . . 5,100

Haddock, Cod, Plaice, Soles, Turbot. Cod, Haddock.

Cod, Haddock, Halibut, Plaice.

Plaice, Haddock, Cod.

Cod, Haddock, Halibut, Coalfish.

Cod, Coalfish, Haddock.

Hake, Bream, Rays.

Hake, Bream, Haddock.

Cod, Coalfish, Hake, Ling, Halibut.

Haddock, Ling, Cod, Halibut

Hake, Skate, Monks, Soles.

Hake, Skate, Bream, Soles.

Skate, Cod, Plaice, Soles.

1 For average duration of a trawling voyage on each of the various grounds, see below, p. 200. 
These regions for the most part are easily recognizable on the chart, ${ }^{1}$ but the following need a fer words of explanation:

1. 'South of Ireland' is an area 50,500 square miles separated on the east by the 50 -fathom line from the English Channel and Bristol Channel. It is generally known as the "South-West Bank'. The northern boundary is the coast of Ireland as far as a line west from Loop Head.

2. 'Westward of Scotland' is an area 32,100 square miles, bounded on the east by the meridian $5^{\circ} \mathrm{W}$. and the west coast of Scotland; on the south by the northern limits of the Irish Sea and the north and west coast of Ireland as far as a line due west of Eagle Island.

3. 'Westward of Ireland' is the area between the lines west of Eagle Island and Loop Head. The area is 9,066 square miles only.

These western grounds in the Atlantic are of immense interest as they form the meeting place of 'Northern' fish like coalfish and halibut, and 'Southern' fish like hake and skate and bream.

1 See General Map of the Great Fisheries. 


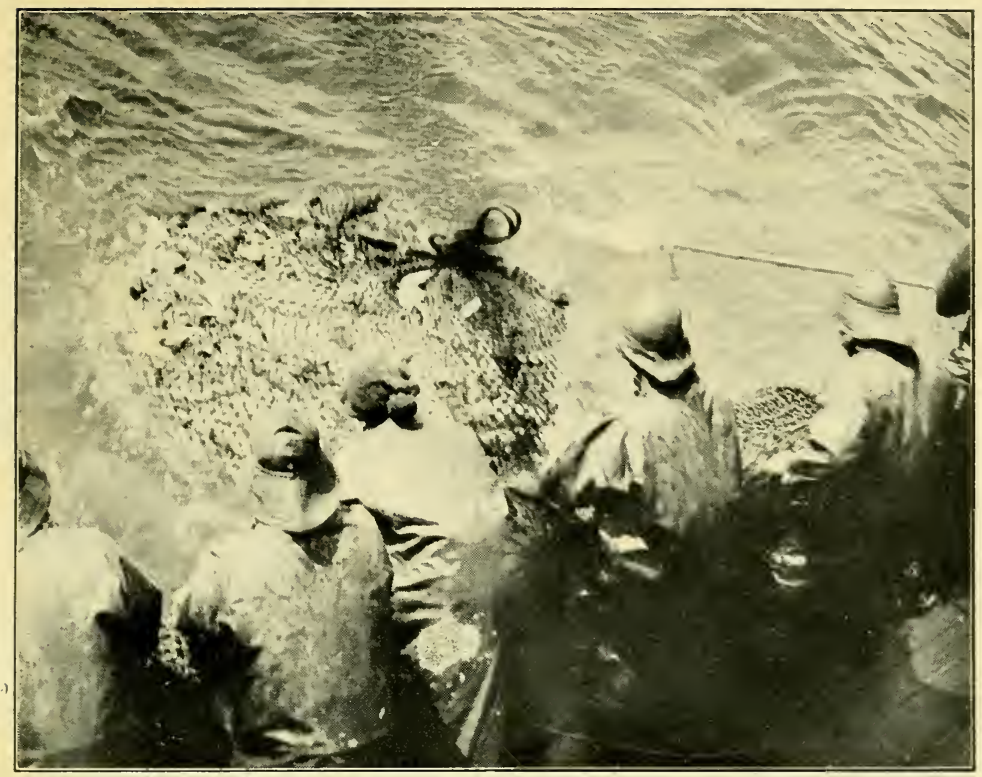

The nct alongside in rough weather.

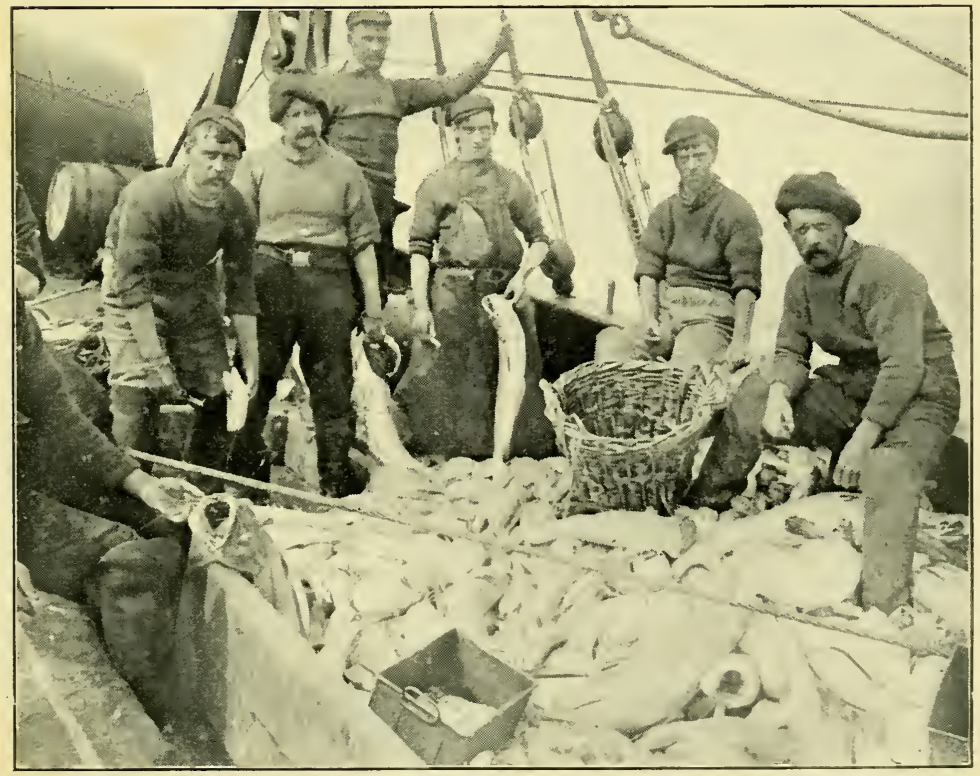

The catch on deck.

STEAMTRA W I N 



\section{CHAPTER III}

\section{THE ORGANIZATION OF OCEAN RESEARCH}

OCEAN investigations are, most wisely, divided up among the nations by the permanent International Council for the Exploration of the Sea. The chairman for 1920 is the Head of the Fisheries Division of the English Ministry of Agriculture, and the Council met in London in 1920. The investigations into the life history of the chief staple fishes landed in this country are at present apportioned as follows :

Herrings to Norway.

Cod, Haddock, and Coalfish to Norway.

Plaice to Great Britain, Belgium, Denmark, Sweden, and Holland.

Hake to France, with some assistance from British and Irish research vessels.

In succeeding chapters the writer has collected as much information as possible about researches into the habits of fish which have actually been undertaken. He will here indicate what he believes personally to be the key to the position, and then comment on the work as a whole. As will appear in the chapters on cod and haddock and herrings which follow, the Norwegians have discovered that in certain years-notably in 1904 and 1912-very abnormal numbers of these fishes survived their babyhood and 'grew up'. So much so that in 1919 people were eating one lot of Norwegian herrings which were fifteen years old, and another lot which were seven. In last year's catches very few fish appeared which had been hatched in the intervening years. The latter were 'bad (or perhaps normal) spawning years', and 1904 and 1912 were 'good (or perhaps abnormal) spawning years'. These terms will be explained in future chapters. ${ }^{1}$ But it is necessary at the outset to know that the discoveries are based on 'scale reading'. Quite briefly this science ${ }^{2}$ starts with the knowledge that fish grow more slowly in winter than they do in summer ; the scales grow as the fish grows; they (like trees) make a good growth in the summer which appears on the scale as a transparent zone ; this is bounded by a narrow opaque ring which is (again as in the case of a tree) formed in winter. A zone and a ring

1 See below, pp. 85, 86, 94-96, and 167.

2 See Depths of Ocean, pp. 759-65. 
therefore show a year's growth, and by counting them it is possible to ascertain the age of the fish from which they were taken. This theory is not as yet universally accepted; but the Norwegian and most other naturalists believe it to be correct. A similar record is known to be engraved on the 'otoliths' or ear-stones and the gill-covers of some fishes-plaice for instance. The scales and the otoliths are in fact fishes' 'identity dises', and to some extent a record of their wanderings. The import of this discovery will appear again and again in the chapters which follow. Meanwhile two or three points emerge with especial clearness.

We know that some cod and haddock and herrings live to fifteen or eighteen years ; that some of them breed for at least fifteen years in succession; but, above all, that the stock of fishes does not (like the stock of civilized men) receive an approximately even accretion each year. There are almost incredible differences between the herring and cod populations of one year and the succeeding year; and these variations are due, apparently, to an infant mortality which in a normal year is, by human standards, cataclysmic.

On the international work this much comment is permissible. In the first place very little effort has hitherto been made to explain it to owners and officers of fishing vessels as it proceeds. 'Popular' lectures and 'popular' publications (like Hjort's ${ }^{1}$ Some Results of the International Ocean Researches) might easily change the attitude of the industry towards Science from one of puzzled tolerance to one of enthusiastic collaboration, for which, the writer is convinced, the time is now ripe.

In the second place this desirable result will be hastened eyery time an investigator boards a trawler at sea for a yarnas is Dr. Hjort's custom, and every time a naturalist is told off for a voyage, or, still better, a series of voyages, on a regular trawler. Men who are to dedicate themselves to fishery research should, some time in their novitiate, from a trawler's deck see a whole year's fishing (winter as well as summer) on some of the deep-sea grounds. This contact between naturalists and fishing skippers is particularly necessary in the case of the ships who are still 'feeling outwards' for new grounds to fish, more especially in the case of the southern hake grounds. The French inquiries on the South-West Banks will no doubt bo most valuable, but the industry wants to see British naturalists aboard of ressels who go south 'to meet the hake'.

1 Published by the Scottish Oceanographical Laboratory, 21 Rutland Street, Edinburgh. 


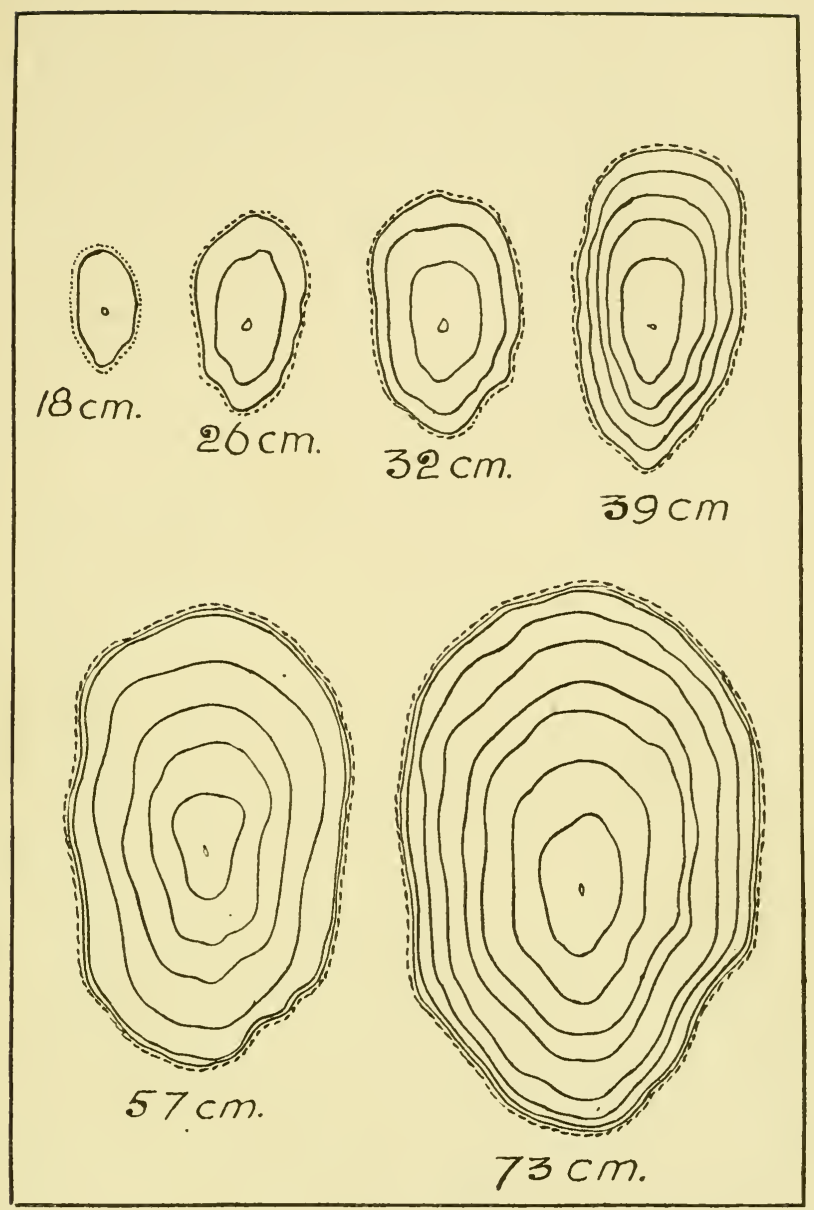

Fig. 1.-SCALES OF COALFISH OF DIFFERENT AGES AND LENGTHS. (After Hjort.)

N.B. : $\quad 38 \mathrm{~cm} .=7$ inches at the end of first year.

$\begin{array}{llll}26 \mathrm{~cm} .=11 & , & & \text { second year } \\ 32 \mathrm{~cm} .=12 \frac{1}{2} & , & & \text { third year. } \\ 39 \mathrm{~cm} .=15 & \text { fifth year. } \\ 57 \mathrm{~cm} .=23 & , & & \text { sixth year. } \\ 73 \mathrm{~cm} .=28 \frac{1}{2} & \text {.. } & \text { ", } & \text { eighth year. }\end{array}$


Again Britons need not lament that so much of the work is handed over to Norsemen, Danes, Swedes, and Frenchmen. There are not nearly enough trained men in Britain to do the work, and, as ocean research means the exploration of the high seas which are free to all, it must be based on international co-operation. There is no room on the high seas for parochialism. The Scandinavians and Danes are not only naturalists but seamen, who speak and understand the language of British seamen better than most Englishmen. They had, moreover, grasped the truth that fishery was an 'ocean' problem while this country still thought in terms of the territorial waters, and bays, and beaches, and county boundaries. All that is true. But each of the fishing 'squadrons' must be in touch with the men-whatever their nationality-who are working out their problems for them; and this means continuous and lucid explanation of the work, not in blue books which appear (sometimes) once a year, but in some form in which it will really reach owners and men as the work proceeds. 'Iceland men', and ' hake men', even men who fish the north of the North Sea-all the 'deep-sea' people, in fact-are wont sometimes to complain that Science has no interest in fish other than herrings and plaice. Nothing could be farther from the fact, though the comparative bulk of English plaice literature and the literature of other species is reflected in these pages. But the deep-sea squadrons who never fish the North Sea shallows cannot at this stage be expected to take much personal interest in the South-Eastern plaice problem, and few, if any, of them know of the work which Hjort, and Schmidt, and Dahl, and others have done on cod, and haddock, and saithe, and hake. They ought to have been told. In $1908 \mathrm{Mr}$. F. Barrett, ${ }^{1}$ on behalf of the Grimsby trawler owners, asked that they should be told. And they should never again be left in ignorance.

Finally, a word-or two to the industry. The wonderful thing-as it will realize when science finds time to explainis not that so little but that so much has been accomplished. Save in Norway, where a distinguished ocean investigator ${ }^{2}$ has been Premier, politicians have not hitherto very enthusiastically encouraged this science, on which, in Hjort's words, the ' life of the industry' depends.

In the 'sixties' men were still wondering whether fish-eggs floated. In a few short years men have by patient, dogged perseverance learnt, amongst many other things, to recognize nearly all the commercial species at every stage of their growth from less than one-tenth of an inch upwards. That alone in-

$$
{ }^{1} \text { Cd. } 4304 \text { (1908), p. } 408 .
$$

2 Dr. Nansen. 
volves more work than most of us laymen would care to contemplate.

As to the 'use of it all'-there is no need to preach to the converted. The industry has for years clamoured for knowledge about the spawning habits and growth and wanderings of food-fishes, not because knowledge will give authority excuses for forbidding something or other, but because without exact knowledge of this kind no one can decide the age at which, from a business point of view, it is best to kill and market the fish. In like manner the sister science of Forestry alone can teach men the proper time at which to fell each kind of tree.

What is not always understood is that the life history of the 'small game' (shellfish, and water-lice, and starfish, and snails) on which young fish feed, and the growth and reproduction of the minute plants on which they, in their turn, browse, are of no less interest than the habits of the fishes themselves. It may seem at first sight to be of little 'practical use ' to discover that barnacles go through a stage of development during which they swim about freely. When one knows the young wandering barnacle (disguised as Balanus nauplius) to be an important item in the dietary of baby turbot one-tenth of an inch long, it at once becomes evident that the weal or woe of barnacles may affect the livelihood of fishermen. But the fishermen cannot realize that by the light of nature. Has Science ever explained? 


\section{CHAPTER IV}

\section{STATISTICS}

Business and Science have this much in common that each must base future policy on sound statistical information. It is commonly believed that the fish on many of our grounds have been profoundly affected by the immunity which they enjoyed during the war. Vessel-owners and naturalists alike are engaged in comparing pre-war and post-war conditions. Can it be said that our statistics give an accurate and easily read picture of the condition of the great fisheries down to 1913 ? It is -generally admitted that they do not. Unfortunately, the figures for ships landing in England and Wales and those for Scottish ports were recorded by separate authorities. This would not matter had they been prepared on a uniform system. But they were not.

The writer has, for instance, attempted to compare the productivity of the northern portion of the North Sea with that of the southern portion in 1913. It is quite impossible, because the northern waters were trawled very heavily by vessels landing their 'voyages' in Scottish ports, and the Scottish authorities make no attempt to indicate the banks from which the catch came. Similarly the English authorities did not separate the work of the 'South-Eastern' vessels from that of the 'North-Eastern'. The figures can, of course, with great labour, be separated; but busy men will not ' dig' in blue books.

A plea is therefore here entered, that British statistics should in future be kept on a uniform basis, and that they should be so arranged as to show at a glance the results achieved by each class of vessel on the grounds which they exploit. They should also show clearly the allocation of the vessels of each port to the various fisheries. It is, for instance, not possible to state from the old reports how many steam-trawlers were fishing out of Grimsby in any given year ; still less to say how many voyages were made from that port to the grounds south of the T'ees-Skaw line, how many north of it, how many to Faeroe, how many to Iceland, and so forth. Yet without such information it.is impossible to judge whether a port is developing or deteriorating, and whether the fisheries are or are not flourishing. 
The Pan-Pacific-Scientific Conference held in Honolulu in August 1920 recommended to the several Governments, ${ }^{1}$ " that systematic statistics of the fisheries be collected and published annually, and that such statisties be, as far as possible, uniform in character and in such detail as to methods of fishing and geographical distribution as to make them useful in fisheries administration and conservation. It is further recommended that the several Governments provide for a joint commission for the arrangement of the details of such statistical compilation.'

That resolution puts the case for the reform of the North Atlantic fishery statistics very concisely.

\section{Compulsory Statistics}

But commercial statistics will never be really efficiently compiled until every Government is invested with the right to demand information from the persons who possess it. At one time a feeling prevailed in the fishing industry that to invest authority with such powers would be to give away one's trade secrets-and it may be that at some ports this idea still lingers, though the writer has never met it. Giving evidence before Mr. Tennant's Committee in 1908, Mr. C. Hellyer spoke as follows : "We think that the time has come when these returns might be made compulsory by the Government giving some fee to the owners for the collection of statistics, and handing them in to a central authority in London, because these matters are considered by the fishermen very private.' He explained 'it would mean clerical work for which they, the owners or salesmen, should be recouped. .If we work sixty steamers, to reckon up those returns for all the week would mean keeping a clerk.' Asked whether it would not still be necessary for the Government to have an officer at the port to see that the thing was properly done, he replied: 'I cannot see that, if you will excuse me for saying so. Here you have a steamer landing 100 tons of fish, and these fish are being placed out at two o'clock in the morning for sale. You cannot conceive what a large business Hull and Grimsby fishing is. There is no fishery officer with regulated hours who would come at that time when the vessel was discharging to ascertain by his own knowledge what those fish consisted of. He must rely on somebody to give the information to him at second-hand; therefore it is better to rely upon a responsible person or authority like the owner or salesman to give accurate information, they feeling all the time that that would be sacred, and that no other

\footnotetext{
1 Japan, Philippines, Australia, New Zealand, Canada, the U.S.A., and Hawaii.
} 
competitor would have the least opportunity of arriving at what they were doing.'

Mr. J. Vivian, who supported Mr. Hellyer, told the Committee: 'I think the fishery officer, in collecting this evidence, will not in two cases out of three get to know where the fish are caught; the fishermen will not tell him-in fact they will not tell the owner sometimes. Some of the owners have the utmost difficulty in getting to know where the fish are caught.' Asked whether the fisherman would not have the same reluctance in giving information under a scheme of compulsion and still prefer to keep his information to himself, the witness replied: 'He might do it, but I do not think he would do it to the same extent as by giving it direct to a local officer at the time of landing the fish.'

Mr. F. Donnison, of Boston, was also in favour of compulsory statistics, and Mr. G. Alward repeated the opinion which he had given to the Committee on Statistics in 1900 to the same effect. Asked whether owners might not object he replied : - They may urge the inconvenience and the cost of making the returns, and that would be a difficulty with which you would have to contend. I have always thought that if you paid a small fee you could command the returns.'

Mr. Bloomfield, of Yarmouth, said: "If this information is to be sought and kept locally, I am afraid there will be so much local prejudice and jealousy that it would militate against getting any reliable data. But if the trawler owners and steam-drifter owners generally were afforded some small recompense for furnishing this information, and if it were sent to a Government Office-say in London-on prescribed forms, I do not think there would be any difficulty.'

Mr. R. C. Ward, of Fleetwood, speaking of the Collector of Statistics, stated: "We do not give him any information; we decline to: we are afraid of his giving information to our neighbours. We are prepared to have forms made out, and a small sum granted to us to send them direct to the officer at Preston who has charge of the district.' These returns he considered would be accurate ; but it would be necessary to refund owners for the expense involved and pay a small fee. "We should have to pay our clerks a little to do it; we do not want the money ourselves.'

Mr. Frank Barrett was also in favour of getting statistical information from owners and salesmen-preferably the latter. Questioned as to the difficulty of discovering the locality from which the fish came, he said: "If a man gets a good voyage of fish he does not want his noighbour to know where he got it. 
It would probably be sufficient for all scientific purposes to know within a little the area he got it from.'

Mr. J. L. M'Naughton, of the Moray Firth Fisheries Association, was of opinion that " trawl skippers ought to be compelled to keep a regular log showing from day to day the catch, and the place where it was obtained.' Only the Scottish fishery officers ought to have access to this log. This suggestion would probably not have covered the objection that skippers were disinclined to give away information which might leak out locally and be used by their local competitors.

So in 1908 it was clear that the Deep-Sea Fleet ownerstrawlers and drifters alike-were alive to two facts: the necessity for getting accurate figures, and the fact that the figures as supplied casually to subordinate officials on the dock side tended to be very far from accurate. They offered to cooperate in securing reliable information, and, in England at any rate, their offer was rejected.

Their opinions have not changed. Mr. G. J. Moody has given evidence on behalf of the British Trawlers Federation to another Committee this year. He reiterated practically all that was said in 1908. The information given to the collectors of statistics had, he said, "depended entirely upon voluntary acts on the part of skippers and mates and other people, and I should say it has been unreliable.' Trawler owners were quite prepared to give figures which would be accurate ' to a few stones'. If firms were provided with printed postcards 'On His Majesty's Service', addressed to London, to be filled in every day from the books, and if they were recompensed for the extra work which it would entail for a clerk-say half an hour's work a day-it would be possible to cut down the staff of collectors at the big ports, who provided inaccurate information, and ensure perfectly accurate returns. He was asked whether it would be possible to get at the place of capture by this means ; he replied that it would be impossible to trace the position within twonty miles, but 'you could get the locality'. There would be no objection, he considered, to an occasional check of the figures thus furnished by periodical inspection of the books. "It is of no interest to anybody. If a vessel lands 1,500 levels of fish, with 5 stones of various kinds, what interest is it to anybody in the world? It does not make any difference to the trawler owner, who knows it.'

\section{The Future}

So there are two possible methods of collecting the statistics of the great fisheries. The present method, which means getting 
figures through subordinate officials from subordinates; and the method suggested by the industry, which is to collaborate with the big firms, and make them responsible for imparting the knowledge which they already possess (and which in their own interests they must make as accurate and complete as possible) direct to central authorities, who are not in the least likely to publish it until its value as a 'trade secret' has long since disappeared. To Business it seems as though there could be no choice in the matter. The writer confesses that, speaking as an onlooker who perhaps sees a good deal of the game, he has long since been converted to the view of the business men. Meanwhile it must be remembered that the figures with which this book is overloaded are accurate only to the extent that the deep-sea fisherman has resisted the temptation to "pull the leg' of a landsman. 


\section{CHAPTER V}

\section{THE PLAICE QUESTION}

\section{The European Catch}

In 1913, the last year for which ' normal' figures are available, the comparative catch of European plaice was approximately as follows :

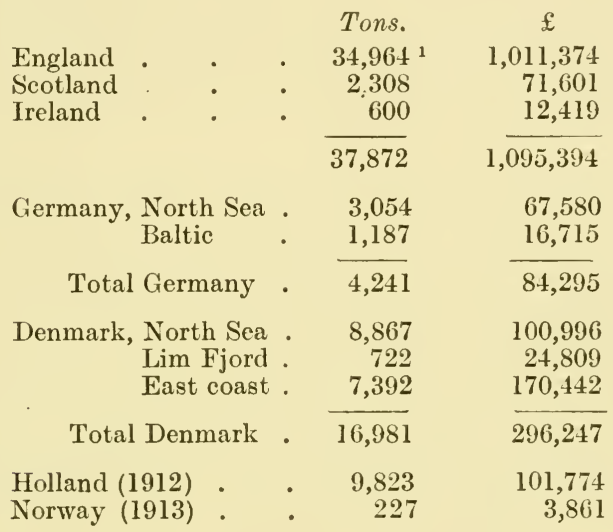

About 73 per cent. of plaice came from the North Sea, ${ }^{2}$ and they formed nearly 12 per cent. of the North Sea catch in 1906.

\section{The British Catch}

British fishermen landed more plaice than the rest of their fishing neighbours put together. Moreover, six ports on the east coast of England produced 90 per cent. of the whole

1 Of which there were landed, on east coast, 32,145 tons ; on south coast, 1,085 tons; on west coast, 1,734 tons. v. Table $1(a)$, Ann. Rep. S. F., 1913. In 1920 the landings were :

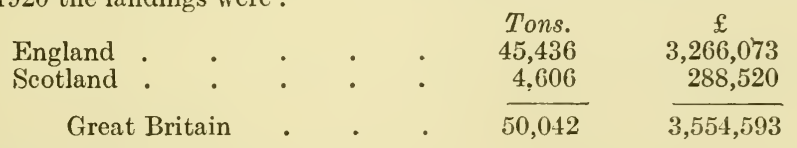

${ }^{2}$ Hjort, Depths of Occan, p. 440. 
English catch. These ports were, working from north to south :

\begin{tabular}{|c|c|c|c|c|c|c|c|}
\hline Hull & • & • & & catching & $6,234 t$ & $\mathrm{~ns}$ & plaice \\
\hline Grimsby & & & • & , & 14,966 & ,. & ,. \\
\hline Boston & & & & ,, & 1,134 &. & ,, \\
\hline Lowestoft & & & • & ,., & 5,549 & ,, & $\therefore$ \\
\hline London & & - & $\cdot$ & , & $2,073^{1}$ & , & , \\
\hline Ramsgate & & • & • & ,, & 1,252 & ,. & ., \\
\hline
\end{tabular}

Total, six east coast ports, 31,208 tons, of which 80 per cent. was caught by steam trawlers.

The remaining fishing ports of England landed between them 6,564 tons, and not one of them as much as a thousand tons in the year.

Of the English catch, steam trawlers landed, in round numbers, 26,300 tons, or 75 per cent.; big deep-sea sailing smacks 7,300 tons, or 21 per cent. ; and inshore fishermen 1,200 tons, or 4 per cent. Quite 70 per cent. of the fish came out of the North Sea, and of this Grimsby probably landed 45 to 50 per cent.

Something like the same proportion holds good of Scotland. The steam trawlers of Leith, Montrose, Aberdeen, and other districts caught 1,540 out of 2,300 tons, or 67 per cent. of the Scottish catch; and the plaice fisheries outside the North Sea are of altogether minor importance.

It is fair to say, therefore, that the Englishman owes the fact that he can obtain plaice all the year round mainly to the exploitation of the North Sea-and especially the southern ${ }^{2}$ portions of that sea-by British steam trawlers based on the east coast.

If all other vessels ceased catching plaice there would be rather fewer fish, and they would cost rather more, but the inconvenience to the public would not be serious, and the fishermen would not be faced with anything like a disaster, though their losses would be quite considerable.

The plaice problem then is, in the main, an English problem, a North Sea problem, and a steam-trawler problem. Before the conversion of the main fishing-fleet into fleets of steam trawlers (between 1893 and 1900) there were, according to Bertram, ${ }^{3}$ at least three times as many soles eaten in London as there were plaice. The British catch of plaice was in 1913 more than ten times as great as that of soles. The latter was,

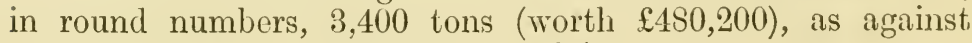
37,800 tons (worth $£ 1,095,300$ ) of plaice.

1 Mostly in Hull vessels

3 Hariest of the Sea, p. 97.

2. Sec below, p. 33. 
The distribution of plaice among the deep-sea fishing-grounds was as follows (the figures being for first-class English vessels only) :

Tons. Tons.

1. South of North Sea * 20,269 20,269

2. North of North Sea $\quad$ - $\quad 1,459 \quad 1,459$

3. Iceland • • • • 4,812

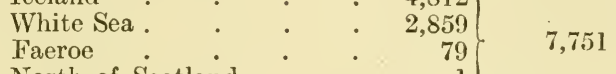

North of Scotland : $\quad 1$.

$\left.\begin{array}{lll}\text { 4. Southward of Ireland . } & \text {. } & 73 \\ \text { Westward of Scotland . } & \text {. } & 37\end{array}\right\} \quad 110$

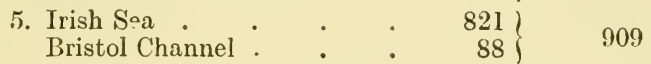

Note on the Statement. 2,382 tons of North Sea plaice came from 'areas' which were not distinguishable. 


\section{CHAPTER VI}

\section{LIFE-HISTORY OF THE PLAICE}

The discussion of the plaice problem has been immensely obscured by a tendency to confuse two totally different thingssymptoms and remedies.

It is proposed here to try to keep the two quite distinct.

\section{Spawning}

Plaice in the North Sea are believed to spawn chiefly in water between 20 and 30 fathoms in depth. Spawning areas have been located at those depths (in areas which marine biologists classify as ' $\mathrm{C}$ ' areas) off the Firth of Forth, the Moray Firth, outside Flamborough Head, in the middle of the Flemish Bight, and in the 'Clay Deeps' between the Dogger and the eastern shore of the North Sea.

Spawning takes place chiefly in January, February, and March. ${ }^{1}$ The eggs measure about one-twelfth inch in diameter ; ${ }^{2}$ they float at the surface so long as they remain in sea water of normal buoyancy. They hatch out in a period said to vary from a fortnight to a month, according as the temperature is comparatively high or low (about $50^{\circ} \mathrm{F}$. to about $41^{\circ} \mathrm{F}$.). During this period the eggs naturally drift 'downstream' of any current in which they find themselves. From the eggs emerge the larvae-about two-sevenths of an inch long.

\section{The Larval Period}

To each of these larval fish is attached a 'yolk-sac', which contains a supply of food. The little creatures live, at first entirely, and afterwards partially, on the contents of this yolk-sac until it is absorbed. All this time they are perfectly helpless; they can make spasmodic and uncontrolled movements, but have little controlled 'poise' in the water, and apparently no sense of direction. It follows that they, like the eggs, will move downstream. They have no power to avoid a predaceous attack, and are more likely than the eggs to be destroyed by enemies, for in the sea, as ashore, immobility is the best form of protection, and the larvae, by their

1 The extreme limits are December to May. Journ. M.B.A., vol. xii, No. 2, p. 194.

${ }^{2}$ I. e. about $206,000 \mathrm{eggs}$ to the fluid quart. 

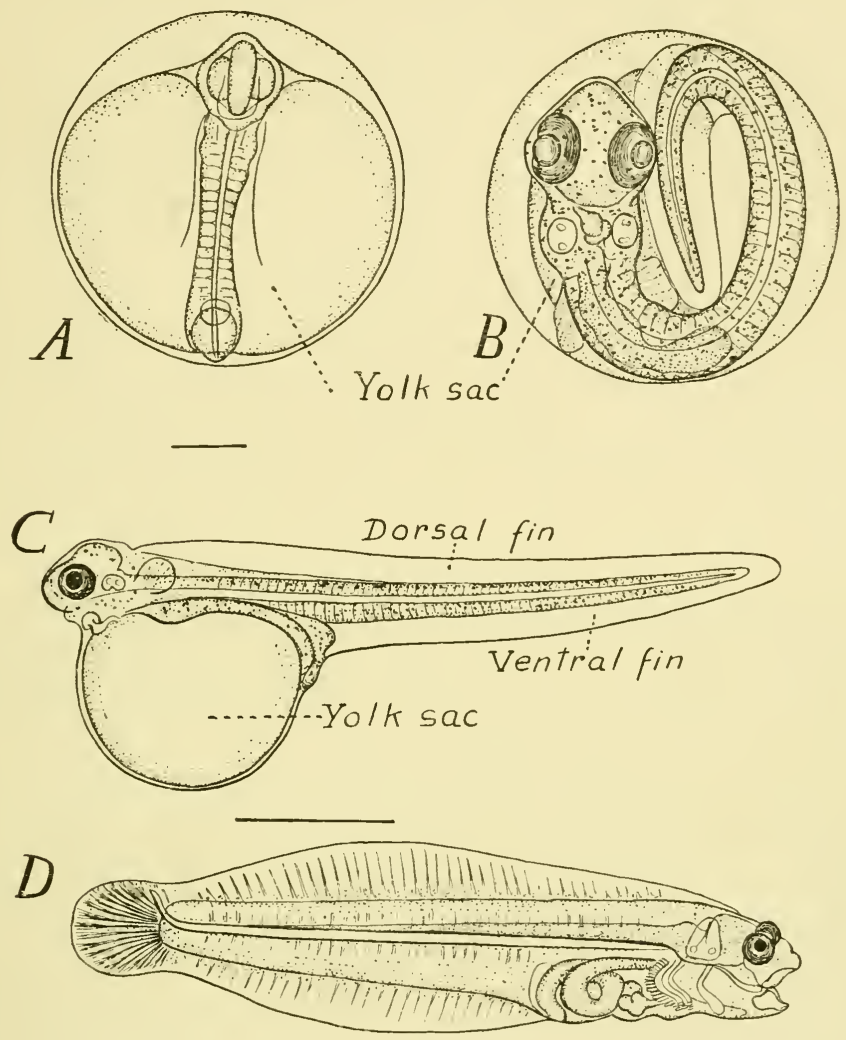

[Drain by Dr. James Jolinstone

Fig. 2.-BABY PLAICE.

A. Embryo plaice, five days old, $2 \mathrm{~mm}$. diameter

B. Embryo plaice ready to hatch, $2 \mathrm{~mm}$. diameter.

C. Larval plaice just hatched, $7 \mathrm{~mm}$. long.

D. Larval plaice beginning to flatten out and beginning to feed greelily, $15 \mathrm{~mm}$. long. 
unconscious wrigglings, must attract very much more notice to themselves than the floating eggs. Fortunately in temperate waters like the North Sea this period of extreme danger is believed to last for about one week only.

\section{Post-Larval Period}

Before the food in the yolk-sac is all consumed, i.e. generally about the fourth day, the larvae begin to feed themselves; they must from this time on be more or less capable of steering a course and breasting a current. Their food consists of diatoms, the larvae of molluses, \&c. About the twelfth day the yolk-sac is completely absorbed and the postlarval stage is completed. It lasts about one week. This period is accepted as the critical period by fish culturists all over the world. It starts with the time when the mouth first begins to function, and ends with the first absorption of the yolk-sac, though the evils produced by infantile troubles may not manifest themselves till the next stage is reached.

\section{The Fry Stage}

(a) The plaice is now a fish, not a 'flat fish' but a round fish, poised and swimming like any young cod or mackerel or haddock. At the end of twenty-one days from hatching it is only three-eighths of an inch long. Its food now includes the young of various crustaceans.

(b) After the thirtieth day the fish take to eating small copepods as well as larval molluses and crustaceans. The left eye begins to move over the top of the head, and by the fortyfifth day it is on the same side of the head as the right eye. Meanwhile the fish has taken to swimming on what was originally its left side, ${ }^{1}$ and is now a 'flat fish fry'. At this stage it is about three-fifths of an inch long. What naturalists call the 'metamorphosis' is now complete, i.e. the fry sink to the bottom and take to feeding on small worms, shrimp larvae, and other crustaceans which live on the bottom. It is often said that the whole life of the plaice is one of danger up to the end of the metamorphosis. This is no doubt true, but it is clear that the danger is extreme in the larval week and in the three or four weeks during which the eggs float about in the sea. Comparative security is reached (and must increase progressively) as the fish gradually attain volition in their search for food. The climax of risk is probably reached when

1 Plaice, soles, lemon soles, dabs, flounders, witehes, halibuts, and the long rough dab swim on their left sides; turbot, brill, and megrims on their right sides. The flat fishes swim on that side which is the heavier. 
the larvae first require a supplementary diet of diatomic plants, not in the period preceding the end of the metamorphosis, but before the absorption of the yolk-sac. It is almost certain that with plaice, as with other small fish, the heaviest mortality occurs when the yolk has all been consumed, and the fish is for the first time wholly dependent on the food it can find for itself. If the larvae have been unable to obtain floating food to eke out the contents of the yolk from about the fourth day of their lives, they are likely to be too weak to survive the critical period when they must learn to forage successfully or die.

\section{The Early Migrations}

On its first 'journey' the plaice turns from a surface fish to a bottom fish. According to Meek ${ }^{1}$ it may, if it finds water deficient in salinity, take to the bottom even in the egg stage, or at any stage up to the time it becomes a flat fish.

Another movement in babyhood is inshore from the spawninggrounds to the 'nurseries'. Not very much is, as yet, known about the stages on this journey. Clearly the eggs and larval fish merely follow the currents. But once a plaice begins to ' swim 'it is possible that instinct teaches it to swim towards the nurseries. At any rate the normal surface drift is towards one or other of these nurseries, and it is there that we next find the fry-on the bottom.

\section{The Nurseries}

Plaice fry are found (about two-fifths of an inch long) gradually moving inshore to the nurseries towards the end of April. Their goal is 'the region between tide marks' (Meek); and nurseries are found in the North Sea all down the east coast of Great Britain in depths down to 10 fathoms, where shallow water and fine sandy bottom are found. The largest accumulations naturally occur in areas where these shallows are comparatively broad, i.e. roughly within lines drawn from Flamborough Head to Cromer across the Wash, and from Lowestoft to the North Foreland across the Thames Estuary. Still greater congregations are found off the Belgian and Dutch grounds, but, owing to the set of the drift southwards down our coast as far as the north coast of Norfolk, and (still more) from Dover Straits northwards over the main spawning grounds and along the Dutch coast, more young plaice find themselves on the shallows off the coasts of Denmark, Sleswig, and Holstein from the Horn Reefs into the Heligoland Bight than in any other region. Here are collected plaice from every portion of the North Sea.

$$
1 \text { Migrations of Fish, p. } 264 .
$$


'These ' nursery grounds ' inside the 10 -fathom line are known to scientists as the $\mathrm{A} 1, \mathrm{~A} 2$, and $\mathrm{A} 3$ areas; and fishermen call the latter, and grounds immediately west of it, as far as the 20 -fathom line, the 'Small Plaice Grounds'. Young plaice at the end of their first summer average $3 \frac{1}{2}$ inches in length, and run twelve to the ounce in weight; a year later they average $5 \frac{3}{4}$ inches and weigh about one ounce; and in the third autumn they are $8 \frac{1}{2}$ inches long and weigh about three ounces. During this period the tendency seems to be to spend the summer inshore, and to move out into deeper and warmer water up to 20 fathoms in the winter; and as the fish grow they naturally come a little less close inshore each summer. Meanwhile the food is gradually changing from the 'fry food worms and small crustacea-to the adult food, chiefly cockles and young mussels, which live respectively buried under about half an inch of sand and in more or less brackish water on clean bottoms.

\section{Maturity}

Generally speaking, male plaice are mature at the end of the fourth summer, and females at the end of the fifth. The size of the fish will by this time vary enormously according as it has frequented grounds where food is more or less plentiful, and according as it has lived in deep or shallow water.

'Range' has been shown by Borley to be a most important feature in determining the growth of fish, as it is in the case of mammals; and the rule 'Big Waters-Big Fish' seems to be as generally true as the mountain shooter's rule 'Big HillsBig Heads', provided always that the deep-sea valleys or the big mountain ranges are not barren of the food of the speciesas is the case in the Barents Sea.

The minimum sizes at which plaice have been found to be mature by Hefford in the southern North Sea in 1910-11 were :

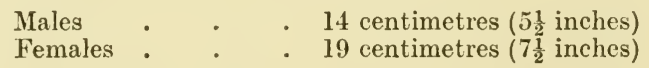

But most of his ' milters ' were $7 \cdot 8$ inches to $9 \cdot 4$ inches in length, and, while there was a considerable number of mature females between $9 \frac{1}{2}$ inches and $12 \frac{1}{2}$ inches in length, it was apparent that a comparatively small percentage spawned before they reached $10 \frac{1}{2}$ inches.

On the Dutch and German coasts, it is believed, most males are four, and most females five years old before they spawn. In the north of the North Sea maturity in each sex is probably a year later.

A very large female plaice may contain as many as half 
a million eggs. What percentage of these are actually fertilized in nature and what are the losses in the egg stage and early larval stages are not known. The losses are certainly heavy. At the Trondjhem Plaice Hatchery an average of 298 females produced an average of 99,000 post-larval fry per female over a period of five years. ${ }^{1}$ The annual averages varied from 13,000 in 1910 , to $91,000,209,000,89,000$, and 132,000 in the succeeding years. The figures show that some factors not yet discovered produce enormous fluctuations in the output of fry bred in captivity. It is not improbable that similar factors ${ }^{2}-$ to which must be added actual attacks by enemies-affect the output year by year on the spawning grounds, and during the early drift from the spawning grounds to the nurseries.

Dr. C. G. J. Petersen, the Danish biologist, has invented an instrument by which he can take up one square foot of the sea bottom. By means of this he has proved that the 'broods' of molluses, and other bottom animals on which plaice feed, fluctuate from year to year as do the 'broods' of herring, cod, and haddock. It is clear that if a large number of baby plaice are hatched out at a time when the free swimming larvae of these molluses are scarce, many of them will die of starvation (or indigestion ?) as soon as the yolk-sac is absorbed. And the same result will follow if there is a shortage of the minute plants we call diatoms. To what extent does the success of a 'hatch' of plaice depend on the presence or absence of these organisms?

\section{Movements of Plaice}

The main feeding-grounds are anywhere south of a line from the Tees to the Skaw. Marking experiments have proved that plaice roam freely over these great feeding-grounds, the four most prolific of which are in the 36,000 square miles between the 10 and 30 -fathom lines in the southern bight of the North Sea. ${ }^{3}$ The general movements of these big fish are summed up by Garstang as a general deployment northwards and off shore in summer, and concentration (generally southward) to the various spawning-grounds in winter. The causes which impel big plaice to move about among the feeding-grounds are not known; but fishermen say that fish will be on certain banks at some states of the tides and not at others. Where they disappear to or why they go is not yet known.

1 Fxperiments along these lines in English and Scotch hatcheries might throw light on the subject.

${ }^{2}$ e. g. prevalence of easterly (unfavourable) or south-westerly (favourable) winds during the fry-stage period. 


\section{CHAPTER VII}

\section{I'HE STOCK OF PLAICE}

The steam-trawler catch on the three chief grounds has fluctuated as follows:

\begin{tabular}{|c|c|c|c|c|c|c|}
\hline & Tons. & $\begin{array}{l}\text { North SEA. } \\
\text { Cwt. per Day } \\
\text { per Trawler. }\end{array}$ & Tons. & $\begin{array}{l}\text { ICELAND. } \\
\text { Cwt. per Day } \\
\text { per Trawler. }\end{array}$ & $\begin{array}{l}\text { (3) BA } \\
\text { Tons. }\end{array}$ & $\begin{array}{l}\text { RENTS SEA. } \\
\text { Cut. per Day } \\
\text { per Trauler. }\end{array}$ \\
\hline 1906 & 22,046 & $2 \cdot 15$ & 9,319 & $5 \cdot 32$ & 1,958 & $34 \cdot 70$ \\
\hline 1907 & 25,731 & $2 \cdot 41$ & 8,617 & $5 \cdot 08$ & 4,063 & $38 \cdot 42$ \\
\hline 1908 & 22,658 & $2 \cdot 36$ & 6,226 & $3 \cdot 92$ & 6,047 & $40 \cdot 45$ \\
\hline 1909 & 22,369 & $2 \cdot 80$ & 5,013 & $3 \cdot 71$ & 14,448 & $50 \cdot 39$ \\
\hline 1910 & 19,475 & $2 \cdot 38$ & 4,536 & $3 \cdot 08$ & 12,799 & $46 \cdot 32$ \\
\hline 1911 & 19,875 & $2 \cdot 57$ & $\tilde{5}, 057$ & $3 \cdot 35$ & 12,785 & $33 \cdot 72$ \\
\hline 1912 & 19,834 & $2 \cdot 84$ & 6,063 & $3 \cdot 92$ & 5,542 & $20 \cdot 15$ \\
\hline 1913 & 17,483 & $2 \cdot 09$ & 4,812 & $2 \cdot 60$ & 2,859 & $20 \cdot 95$ \\
\hline
\end{tabular}

And the total catches were:

$\begin{array}{cccc} & \text { England and Wales. } & \text { Scotland. } & \text { Total Britain. } \\ 1906 & 42,657 & 2,941 & 45,598 \\ 1907 & 48,315 & 2,735 & 51,050 \\ 1908 & 46,180 & 2,470 & 48,650 \\ 1909 & 52,583 & 2,948 & 55,532 \\ 1910 & 47,083 & 2,564 & 49,637 \\ 1911 & 49,308 & 2,668 & 51,976 \\ 1912 & 41,713 & 2,511 & 44,224 \\ 1913 & 34,964 & 2,308 & 37,2771\end{array}$

The English statisties, therefore, such as they are, grive little indication of a continuous diminution of the actual stock in the North Sea. Nor do the statisties from the other main plaice-grounds give anything like an unbroken curve. From a statistical point of view the period is overshort, and continuous observations will now need to start de novo owing to the 'break' between 1914 and 1919 .

The life-history of the plaice, so far as it is known, has been discovered by naturalists, more particularly those working ivith the International Council for the Exploration of the Sea since 1902. Statistical investigations, trawling experiments, and experiments with marked plaice down to 1911 are meanwhile admitted generally to have indicated that the stock of

' The 1920 catch was:

ENGLAND AND WaLes. $45,4: 36$

SCOTLAND. 4,606

Total Britain. $50,0+2$ 
larger and older plaice had been reduced heavily (and especially the stock of larger and older males), and that the proportion of undersized fish in the landings was increasing.

The term 'small fish' is in this sense taken to mean an immature fish which has had no opportunity of reproducing its species. From what has been written about 'maturity" it will be seen that it is impossible to fix any hard and fast size-limit below which all fish are 'immature'. 1 But, roughly spealing, a fish less than $11 \frac{1}{2}$ inches in length is a 'small fish'.

The proportion of small fish in the landings from the North Sea was :

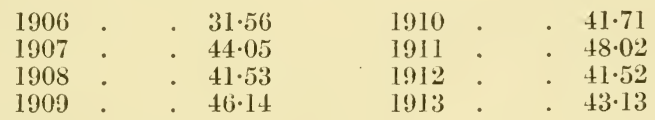

The small fish landed from the different regions in 1913 were roughly :

From the Southern Grounds:

From the B 3 area . . . . 3,700 tons.

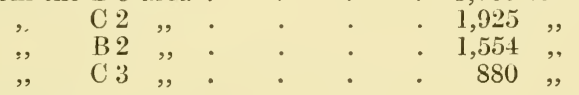

From the Small Plaice Grounds:

From the A 3 area. $\quad . \quad+\quad . \quad 880$ tons.
, B $4, \quad . \quad 645,$,

So the small plaice were nearly all from the south of the North Sea. From all other grounds the landings of 'small' plaice were negligible in quantity, though the percentages look high.

For the explanation of this 'lettering' the reader should study the chart of the North Sea [Map i]. The letters are affixed as follows:

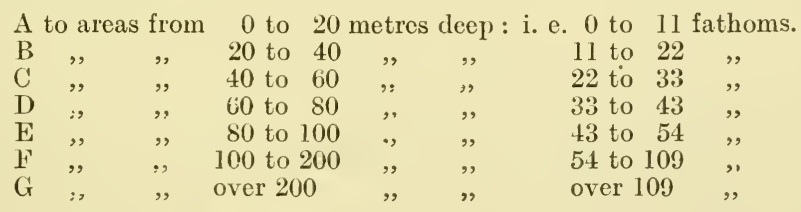

It must always be remembered that these statistics take no account at all of 'small' fish thrown overboard (many of which must be dead), but only of 'small' fish landed. In

1 The 'Trade ' categories ' large ', 'medium', and 'small' do not help much. Analysis shows that in Grimsby 'large' fish mean anything between 9 and 28 inches. 'Medium' fish are 9 to 13 inches; and 'small' fish from $5 \frac{1}{2}$ to $11 \frac{3}{4}$ inches. 
deciding whether or not to bring his 'small' plaice to shore a skipper will always be guided by two considerations: (1) Is there a fair chance of filling up with bigger fish? (2) Is there a demand ashore for fish of that size? If a big demand for smaller sizes of plaice has grown up since 1906 the statistics may mean little more than that plaice which were once thrown away are now eaten, particularly in the fried-fish shops.

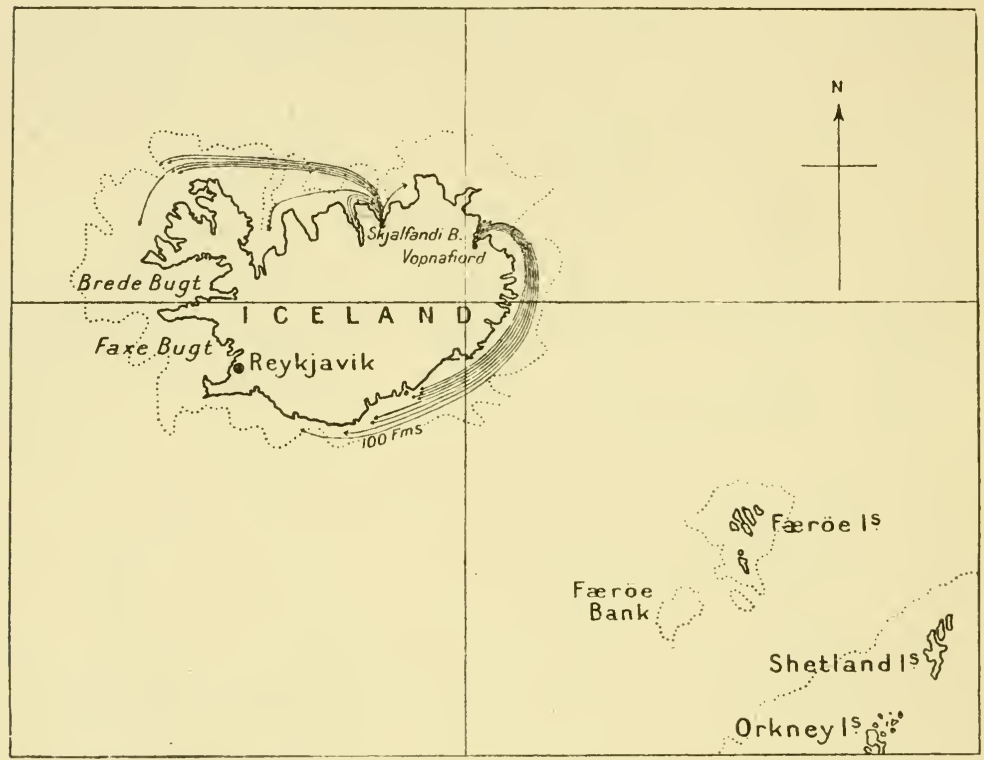

FI: 3.-Marking Experiments from Iceland showing that in the spring the mature plaice wander from colder waters (Vopnatiord and Skjalfandi Bay) to the southern and western shores in order to find suitable spawning conditions. (Dr. Hjort after Dr. Schmidt.) The plaice in the North Sea do not appear to migrate. to such an extent as in Icelandic waters.

\section{Marking Experiments}

Many experiments have been made with marked plaice in order to discover what percentage of the plaice population is caught in the trawls every year. A certain number of fish, say one hundred or one thousand, are marked with labels and liberated on a particular ground. In the year after they are cast adrift a certain number of these marked plaice (say 10 to 40 per cent.) will be recaptured in a certain area. If it is assumed that the marked fish have distributed themselves uniformly amongst the unmarked fish, the inference is drawn (and is perhaps to some extent legitimate) that approximately 
the same percentage (10 to 40 per cent.) of all the plaice in the area are captured. But there are so many hundreds of millions of plaice in the sea that inferences drawn from experiments with a few hundreds of fish must obviously be received with extreme caution. They are in fact subject to a very heavy "margin of statistical error", more especially as the plaice population has never been satisfactorily computed. Will any one ever be able to prove that there are so many millions of plaice in the sea? It is hardly probable. For fish, unlike men or cattle, do not receive an approximately even accretion to their population every year. On the contrary, it will almost certainly be found that in most years a huge but very variable proportion of infants is destroyed. It has been computed from experiments that 20 to 40 per cent. of all the plaice on the grounds are captured every year. But such computations will not perhaps convince a really sceptical mind.

\section{The Causes of Diminution of Large Plaice Landings}

Erer since they began to be conscious that plaice were being ' fished out' - which was at least thirty years before naturalists were in a position to confirm their belief-trawlermen have ascribed the trouble to the operations of the trawl. At the outset the fishermen were told that the supplies of fish were 'inexhaustible', and that the destruction wrought by man could never spoil the supply. The fishermen ' knew better'.

\section{Trawling on Small Plaice Grounds}

Skippers and owners up to the outbreak of war were agreed that the exact process was just this. The trawlers found that from the middle of April to the middle of August profitable catches could be made on the nursery grounds between the Horn Reefs and the Heligoland Bight. Competition drove them against their better judgment to catch these fish. As Skipper R. Douglas, of Grimsby, put it to Mr. Tennant's Committee in 1908: "While one can do it, another thinks he ought to do it, though he knows it is not right. Three captains that I have spoken to this week have said the same thingthat it will ruin the grounds if something is not done.' That was the view of the trawler owners and fishermen in the plaice ports in 1908-and long before it. Too many immature fish were caught on the nurseries before they could get into deep water to grow and spawn. It would be "better business" for the catcher and for the nation to allow these small fish to 
grow to a larger size before eatching them. That, after years of inquiry, was the finding of the International Council in 1913 as expressed by Heincke.

\section{Trawling in the Large Plaice Grounds}

The Council went further and attributed the reduction in the number of older and larger plaice landed in part to intensive trawling, especially to trawling on the spawning grounds.

\section{Shrimp Trawlers on the Nurseries}

It was left to the trawlermen, and to certain English naturalists, to point out the immense damage done to the plaice fry by the shrimp trawlers off the Wash, the Norfolk and Essex coasts, and the Thames Estuary, a question which will be discussed more fully later.

\section{The Effect of Catching immature Fish on the Stock}

There was then a very large consensus of scientific and business opinion that the large catch of immature fish actually reduced the stock of plaice. But on this point opinion is not unanimous. A school, of which Garstang is the protagonist, holds that there was no proof that the falling-off in the catch of large fish was due to the increased catches of small fish. They admit that there were before the war fewer large plaice, in the North Sea generally. Garstang thinks that the trawlers catch (a) numbers of young plaice as they are migrating, and $(b)$ numbers of mature fish on the spawning-grounds. So the central grounds, which are the finest feeding-grounds, do not get their natural supply of fish to graze on them; and half the large plaice are caught just as they are 'ripe' for the first time. Hence the increased proportion of small plaice in the trawler's catches. Probably there were before the war actually more small plaice in the sea just because the big ones were killed so extensively that they left more space and more food for the small fish, and so the infant mortality among the small plaice had diminished.

'Their opponents maintain that there is no roason to think that young plaice do die to any great extent for want of food or for want of space. 'That, on the contrary, they are extremely hardy ; that they do not eat the same food as adult plaice ${ }^{1}$

\footnotetext{
1 Professor Garstang's point is that the big fish destroy the parent cockles which would have produced numbers of small cockles on which the small plaice feed. Petersen's investigations seem to show that the 'broods' of young cockles vary very much from year to year, exac: 'y like those of cod and herrings.
} 
at all ; and that the shortage of young fish, which undoubtedly occurs periodically, as Garstang was the first to demonstrate, is due to catastrophes to the eggs at and after spawning, and to the larvae, especially during the first critical week or so after hatching. If Garstang is right, measures to protect young fish would be useless, and the old fishermen's adage, 'You that wish to live and thrive, save a little dab alive', is nonsense, for protection of young fish will never produce more big fish. As will be seen below, it is now probably possible to discover whether Garstang or the other school is right.

\section{Principles underlying Remedies}

In devising remedies the legislator must keep before him two questions :

1. Would the remedy, if applied with reasonable efficiency, have the desired effect?

2. Is it possible to apply it with reasonable efficiency? He must remember that no remedial measure is likely to be effective unless the people whose operations will be affected by it believe in it on the whole; that no remedy will be perfectly efficient; that any remedy will raise a certain amount of opposition and press hardly on some individuals. In fact, biologists are undoubtedly well qualified to judge whether the stock of plaice does or does not require protection. Protection will always mean some degree of restriction, which will succeed or fail according as it has or has not the goodwill of the persons whose operations are to be restricted. At this stage, therefore, it is obviously desirable that naturalists should collaborate with the managers and skippers of fishing-vessels. Science has been defined as 'the systematic classification of experience'. And the scientist will be well advised if, before prescribing remedies, he thinks out all difficulties in the way of carrying them out with the men best capable of judging their practicability. 


\section{CHAPTER VIII}

\section{TRANSPLANTATION AS A REMEDY}

\section{First Suggestion published by the Industry, 1894}

On the 22nd May 1894 Mr. R. Douglas, a Grimsby steamtrawl skipper, read a paper before the National Sea Fisheries Protection Association. His argument was as follows. Large quantities of plaice, 8 to 10 inches long, were to be had on the Dutch, German, and Danish coasts in the summer months. $\mathrm{He}$ had observed that plaice caught fifteen to twenty-five miles off shore from these grounds were, on the average, much larger, and, in many instances, had arrived at maturity, i. e. were 15 to 17 inches long. He advocated the building of a special steamer with 'wells' to contain 30,000 live plaice of 8 to 10 inches. She would fish the small fish-grounds with light gear, hauling her trawl once every hour so as to avoid killing the young plaice, and would fill her wells with live fish in two or three days. She could make six trips a month, which would give her 1,080,000 small plaice in a season of six months. She would turn her young fish adrift on the Dogger Bank, the Leman Banks, and on other grounds 'close in to our own shores'. In choosing grounds to which to transplant his fish he gave preference to places in which steam-trawling was not so intensive as to destroy them before they had grown. Thus on the Dogger " there is plenty of ground that is not worth working, because it has been fished clean long ago'. On the Leman, ' in the winter months, as a general rule, we have not many vessels that fish there, and when these fish are set adrift near some parts of our shores, they will have to go, in some cases, twenty miles before they are likely to be caught, as there is not much trawling done within this distance.'

He assumed that one-third of the fish thus transplanted would be caught during the first summer, one-third in the second year, and one-third in the third year. Allowing for growth, he calculated that the effect would be as follows :

First year : 360,000 plaice at 150 to the $b^{1}=2,400$ boxes sold at 10s. per box

Second year : 360,000 plaice at $7 \dot{5}$ to the box $=4, \dot{s u 0}$ boxes sold at

El per box
Third year : 360,000 plaice at 50 to the box $=7,200$ boxes sold at

£l 5s. 0d. per box.

Final value of transplanted fish

9,000

' A box is approximately $80 \mathrm{lb}$. 
The cost of the first year's operations he estimated as follows:

Cost of steamer . . . . . . . . . 5,000

Six months' working expenses at $£ 65$ per week $\quad . \quad$. $\quad . \quad 1,560$

Gross expenses . . $\overline{6,560}$

Less earnings by sale of marketable soles, turbot, and plaice caught incidentally during operations at $£ 30$ per week . . . . 720

Nett expenses . . $\overline{5,840}$

If the experiments were continued over a period of five years, he argued, "it would give us 5,400,000 fishes, and as we should be putting in fish in the second year when only one-third had been taken out, and when some had started to spawn, the increase would be enormous. As 5,400,000 have been transplanted, we might well believe they would in this time have increased to $10,000,000$, and taking into consideration that a great many would be full grown, then I believe we may assume that 100 of these will fill a box; if so, that gives us 100,000 boxes, and at $£ 1$ per box shows a net return of $£ 100,000$.'

Against this he sets :

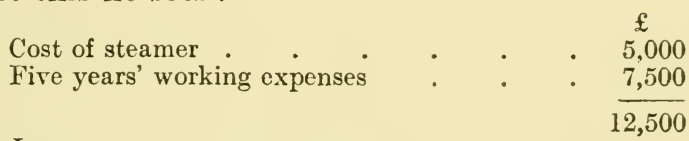

Less

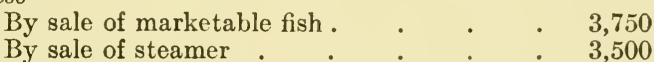

By sale of steamer . . . . . 3,500

7,250

Nett expenses . . . . . . 5,250

For a return of $£ 100,000$.

Mr. Douglas realized that Germany, Holland, Denmark, Norway, Belgium, and France might well be invited to do their part in the carrying out of his experiment. But he remarked (sagely enough), "it is probable that this would not be accomplished for the next ten years', and concluded that as we owned 80 per cent. of the trawling power in the North Sea we might get to work at once on our own account.

Mr. Douglas also advocated the transplantation of large Iceland and Faeroe and Irish Channel plaice to the North Sea grounds to secure 'fresh blood' ; the transplantation of small 1 North Sea plaice to the Irish Channel feeding-grounds, and the transplantation of small soles (4 to 6 inches long) and turbot to the North Sea from the Bay of Biscay.

1 In 1908 Atkinson actually transplanted plaice from the Barents Sea to the North Sea, and found that they grew more quickly there than in their native waters, 
He was examined as a witness in 1908 by Mr. Tennant's Committee on Fishery Investigations, which printed his original paper as an Appendix to its report. ${ }^{1}$

\section{Professor Garstang's Experiments}

Scientific experiments in transplantation were reported from Denmark by Petersen in 1896, and from 1904 to 1908 the Marine Biological Association ${ }^{2}$ carried through an admirable series of experiments. Science had already discovered that the Dogger Bank produced very few plaice below 12 inches in length; and that 'the absence of small plaice there was probably due, not to any unsuitability of the conditions, but to the fact that this region is surrounded by a barrier of deep water across which, for some reason, young plaice could not move from the inshore nurseries'.

The experiments were carried out by Messrs. Garstang, Borley, Atkinson, and Potter. Three transplantations were made in the first year :

(1) 441 plaice from Bridlington Bay to the Easternmost Shoal of the Dogger (14th April).

(2) 362 plaice from the Horn Reef Grounds to the Tail of the Dogger (25th and 26th May).

(3) 344 plaice from the Horn Reef to the Easternmost Shoal (25th and 26th May).

All transplanted fish were marked with brass labels.

Mr. Douglas had conjectured (he said in 1908) that plaice thus transplanted would grow nearly twice as fast as on the small-plaice grounds; and that one-third of them might be caught in the first year, and two-thirds left to grow. The fact appears to be that the Dogger is a submerged island. Between it and the eastern grounds is a belt of deep water with a muddr bottom, which the little plaice, for some reason still to be discovered, ${ }^{\mathbf{3}}$ find difficulty in crossing. Transplantation is, in effect, merely helping them to cross this barrier. Transplanted fish of $8 \frac{3}{4}$ inches in length put on a growth of $5 \frac{1}{4}$ inches in the first year on the Dogger, as against 2 inches on the Small Plaice Grounds. In weight they increased 382 per cent. on the Dogger as against 100 per cent. on the eastern grounds.

1 Cd. 4304 (1908). Price $4 s .6 d$.

2 Walter Garstang, Experiments in the Transplantation of Small Plaice to the Dogger Bank, C'd. 2670 (1905). Cf. also Borley's Memboir, Cd. 6125 (1912).

3 Probably the little fish do not find the food they want during the frequent. halts which would be necessary for them. 
The experiments showed that the rate of recapture would depend upon the date at which transplantation took place. In April and May the Bank was heavily fished; from June to September there was little trawling.

\section{First Scientific Proposals, 190:}

Professor Garstang worked out an invaluable 'Forecast of the Commercial Results of Transplantation'. He prepared a table to show the estimated yield and value within the first year of a stock of one million small plaice transplanted to the Dogger Bank (A) in the middle of April, and (B) at the end of May, as follows:

A. Number available for capture.

Average.

Length. Weight. Value. Per

Inches. Oz. Percut. cent.

Apr.-May $1,000,000$

June-Sept. $\quad 750,000$

Oct.-Feb. $\quad 660,000$

Total yield

Remainder

uncaught 554,000

$B$.

June-Sept. 1,000,000

Oct.-Feb. $\quad 880,000$

Total yield -

Remainder

uncaught 739,200

\section{$8 \cdot 5$}

$10 \cdot 2$

$13 \cdot 7$

$$
3 \cdot 38
$$

$$
5 \cdot 75
$$

$15 \cdot 00$

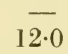

22.6

\section{5}

12

16

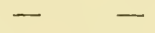

14

15

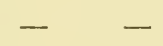

$9 \cdot 5$

$13 \cdot 3$

\section{$4 \cdot 6$}

$13 \cdot 75$

$10 \cdot 0$

$22 \cdot 6$

12

140,800

Probable total Catch.

Number. Weight. Value.

\begin{tabular}{rrc}
250,000 & 471 & - \\
90,000 & 284 & 173 \\
105,000 & 884 & 994 \\
195,600 & 1.173 & 1,167 \\
\hline & & \\
- & 4,950 & -
\end{tabular}

The conclusion was that transplantation on a commercial scale should be carried out in June after the close of the spring fishing on the Dogger. 1,000,000 fish thus transplanted would give a yield of 1,388 cwt., or 11,104 stones, valued in 1905 at $£ 1,369$ (as this is written in September 1920 they would be worth $£ 5,000$ at Billingsgate); and this would leave nearly 750,000 plaice in the North Sea, all of the best marketable size and weight, to be caught the following year. This represents at least 55,000 stones (a 'box' is about $5 \frac{1}{2}$ stone) of large plaice, which even on a glutted market should fetch $£ 29,000$ on the quayside in September 1920.

Garstang considers that the figures show that the proceeds of transplantation would cover all expenses within a year from each undertaking. In order roughly to test this assertion in 1920 it would perhaps be legitimate to treble Mr. Douglas's estimate of the cost of five years' successive transplantations. If this cost were approximately $£ 30,000$, and if it produced an 
annual addition to the stock of North Sea plaice worth $£ 34,000$ and left the experimenters in possession of a vessel saleable at $£ 10,000$ at the end of five years, it is clear that Garstang's position was unassailable. And in point of fact no one has ever challenged his conclusions.

\section{No Action Taken}

But no one did anything! In 1905 Garstang had shown how to improve the plaice fisheries. But for a variety of reasons, ranging from universal fear of Germany to the fact that fisheries did not interest politicians, no attempt was made to apply his remedy, and up till 1914 the plaice landed seem gradually to have become smaller.

\section{The Present Position (1920)}

Then came the cyclone in 1914. As a result perhaps of more or less complete closure of the feeding-grounds against fishing in war-time, they are, at present, well stocked with large fish. Science and Industry and Officialdom have time to look round. All are agreed that the resuscitation of the stock is only temporary, and that the big fish will soon be 'fished out' again. Meanwhile Science is determined to discover whether young transplanted plaice grow as quickly on crowded grounds as they did in the previous period of depletion. And meanwhile Experience in the shape of Mr. Neal Green (trawler owner, fish-curer, and author of Fisheries of the North Sea) has revived a suggestion originally made by Garstang in 1906.

Is it possible for the nations-or our nation-to pay the Danish fishermen with their ' well smacks' to transplant small fish to the Dogger instead of putting them on the market? There are 'difficulties' in the way of course, and difficulties quite likely to baulk official action. Provisional arrangements made by Garstang to this end in 1906 might easily have succeeded, but failed, apparently, for lack of official support in this country.

The writer is inclined to think that this idea might be worked as a commercial transaction by the (now) organized trawling trade of Great Britain. At any rate, when the large plaice begin once more to be scarce on the feeding-grounds, the British Deep Sea Fishing Fleet, thanks to Science, knows one potential remedy. If that is not tried in time the fleet will have only itself to blame. It prides itself on its position as the premier fleet in the world. So it must lead, and, if necessary, leave other fleets (and statesmen) to follow. 


\section{CHAPTER IX}

\section{THE COMPARATIVE PRODUCTIVITY OF THE PLAICE GROUNDS (ENGLISH PLAICE FISHERY)}

THe following figures are extracted from Statements V'II and VIII of the Annual Report on Sea Fisheries, 1913: ${ }^{1}$

I. South of Tees-Skaw Line (catch by First-Class Vessels)

\begin{tabular}{|c|c|c|c|c|c|c|c|}
\hline \multirow[b]{2}{*}{$\begin{array}{c}\text { Area. } \\
\text { B } 3\end{array}$} & \multirow{2}{*}{$\begin{array}{l}\text { Square } \\
\text { miles. }\end{array}$} & \multirow{2}{*}{$\begin{array}{c}\text { Plaice } \\
\text { caught. } \\
\text { Tons. } \\
6.598\end{array}$} & \multirow{2}{*}{$\begin{array}{l}\text { Tons per } \\
\text { square } \\
\text { mile. } \\
0.6\end{array}$} & \multicolumn{2}{|c|}{$\begin{array}{c}\text { Trawler catch in } \\
\text { cwt. per day's } \\
\text { absence. }\end{array}$} & \multirow{2}{*}{$\begin{array}{c}\text { Plaice } \\
\text { formed } \% \\
\text { of catch. } \\
55.46\end{array}$} & \multirow{2}{*}{$\begin{array}{c}\text { Of which trade } \\
\text { sorted as } \\
\text { 'small' \%. } \\
56.51\end{array}$} \\
\hline & & & & $\begin{array}{l}\text { Steamb. } \\
5 \cdot 17\end{array}$ & $\begin{array}{l}\text { Sait. } \\
1 \cdot 91\end{array}$ & & \\
\hline $\mathrm{C} 2$ & 17,716 & 5,536 & 0.3 & $2 \cdot 45$ & $1 \cdot 77$ & 12.90 & $34 \cdot 36$ \\
\hline B 2 & 5,897 & 3,680 & 0.6 & 3.01 & $0 \cdot 90$ & $29 \cdot 21$ & $42 \cdot 18$ \\
\hline C 3 & 1,864 & 2,165 & $1 \cdot 1$ & $4 \cdot 78$ & $1 \cdot 22$ & $44 \cdot 57$ & $39 \cdot 46$ \\
\hline A 3 & 4,761 & 992 & 0.2 & $8 \cdot 89$ & - & 59.97 & $80 \cdot 54^{2}$ \\
\hline B 1 & 6,846 & 686 & $0 \cdot 1$ & $0 \cdot 76$ & - & $4 \cdot 22$ & $6 \cdot 88$ \\
\hline B 4 & 6,365 & 463 & 0.07 & 5.07 & - & $20 \cdot 60$ & $75 \cdot 45^{2}$ \\
\hline B 5 & 2,828 & 97 & 0.03 & $2 \cdot 89$ & - & 13.73 & $80 \cdot 57$ \\
\hline A 1 & 3,098 & 49 & 0.01 & 0.98 & 0.44 & $21 \cdot 50$ & 33.93 \\
\hline Total & $\overline{60,080}$ & $\overline{20,266}$ & & & & & \\
\hline
\end{tabular}

II. North of Tees-Skaw Line (catch by First-Class Vessels)

$\begin{array}{crrlllrr}\text { C 1 } & 5,729 & 686 & 0 \cdot 1 & 1 \cdot 63 & - & 10 \cdot 61 & 13 \cdot 23 \\ \text { D 1 } & 10,223 & 433 & 0 \cdot 04 & 0 \cdot 44 & - & 2 \cdot 88 & 9 \cdot 75 \\ \text { D 2 } & 12,131 & 192 & 0 \cdot 01 & 0 \cdot 75 & - & 2 \cdot 68 & 2 \cdot 86 \\ \text { E } & 16,483 & 110 & 0 \cdot 006 & 0 \cdot 28 & - & 1 \cdot 38 & 15 \cdot 59 \\ \text { F } & 28,803 & 30 & 0 \cdot 001 & 0 \cdot 07 & - & 0 \cdot 22 & 7 \cdot 48 \\ \text { Total } & 73,369 & 1,451 & & & & & \end{array}$

III. Undistinguished, But Chiefly from Southery Grounds

$$
\begin{array}{llllll}
2,382 & - & 2.21 & 1.28 & 10.74 & 38.40
\end{array}
$$

1 The 1920 figures were (for a greatly increased fleet) :
I. South of Tees-Skaw line
Tons.
II. North of Tees-Skaw line 3,360
III. Undistinguished . . . . . . 665

The catch from all ' $\mathrm{A}$ ' areas fell from 1,041 tons in 1913 to 241 tons in 1920 owing to the reduction of fishing off the Danish coast. The total increase was 8,455 tons.

2 The Small Plaice Grounds. 
It must be remembered that these figures reflect only the condition of the main plaice fishery in a single year ; that about 8 per cent. of the catch was landed from North Sea grounds which were not specified; that the collectors of statistics are not always told 'the whole truth, and nothing but the truth' by trawler skippers; and that the trade sorts its fish into ' large,' 'medium,' and 'small' on no uniform or exact system. The table, in fact, makes possible only a very rough comparison of the various areas.

With this proviso it can be noted :

1. That the southern portion of the North Sea (the 'belly' and ' cod end' in fact of a sea which is shaped very much like a trawl-net !) produced 17,979 tons out of 21,731 , or 82 per cent. of the catch by the big vessels. ${ }^{1}$ The whole area (of 36,183 square miles) lies roughly between the 10 and 30 -fathom lines. It is bounded to the south by a line between Cape Grisnez and the South Foreland; on the north (roughly) by the Dogger and the Great Fisher Banks ; on the north-west by the "small-plaice grounds' ; and elsewhere by the 10 -fathom line. It is probably true that some 70 per cent. of the plaice landed from this area were mature fish.

2. That the 'small-plaice grounds' off the Danish, German, and Dutch coasts (the A 3 and B 4 areas) produced between them 1,455 tons, or 6 per cent. of the North Sea catch.

If these small-plaice grounds had been closed altogether to trawling by English vessels, therefore, there would have been just 1,455 tons less plaice on the English market, of which 32 tons would have been 'large ' fish, 256 tons ' medium' fish, and 1,149 tons ' small' fish. Allowing 4,200 'small' fish to the ton, it is clear that complete closure of these grounds would have saved some 4,800,000 small plaice. These represented 32,000 'boxes', of $5 \frac{1}{2}$ stone each, in 1913. They sold at about $£ 18$ per ton, i.e.over $£ 20,600$. If $4,000,000$ of those small fish had been transplanted to the Dogger when they were 9 inches long and just over 4 ounces in weight in June and September 1913, some 2,956,800 fish, averaging 14 inches in length and $1 \mathrm{lb}$. in weight, and weighing 1,320 tons, would have been available for capture in April 1914. They would then have been worth $£ 39$ a ton, or $£ 51,480$. In addition to this, about 277 tons would have been caught on the Dogger and sold as 'small' fish at about $£ 5,000$, in the summer and autumn of 1913.

1 The fish from ' $\mathrm{C} 3$ ' are eaught practically exclusively in the winter when the plaice have congregated for spawning. 
The Effect of Closure accompanied by Transplantation

So that by closing the small-plaice grounds and transplanting $4,000,000$ small plaice from these grounds to the Dogger, the net gain in value and weight to the plaice fishery could have been thus expressed:

By 277 tons small plaice caught on Dogger $1913 \quad$. $\quad . \quad$. $\quad \begin{gathered}\mathfrak{5}, 000 \\ 5,000\end{gathered}$ By 1,320 tons large plaice available $1914 \quad \cdot \quad \cdot \quad \cdot \quad \cdot 51,000$

56,000

Less potential price of same if all marketed in 1913 from small-plaice grounds

Gross gain by closure and transplantation . . $\quad . \quad \overline{35,400}$

And from this, of course, it would be necessary to deduct the cost of transplantation.

If, on the other hand, 4,800,000 small plaice, averaging $9 \frac{1}{2}$ inches and $4 \mathrm{oz}$., had been left to grow on the small-plaice grounds in 1913 they would have averaged about $11 \frac{1}{2}$ inches by May of 1914, and the increase to the stock of fish in the North Sea would have been, though much less than the growth on the Dogger, still considerable.

3. The remaining considerable plaice grounds produced fish as follows :

The Dogger Bank (B 1) . . . . . . . $\begin{gathered}\text { Tons. } \\ 686\end{gathered}$

The 20 to 30 -fathom grounds ${ }^{1}$ west of the Dogger (C I) . . 686

The huge $30-40$-fathom grounds ${ }^{1}$ between the Dogger and the "Long

Forties' (including the latter) (D 1) . . . . . 433

Only a very small proportion of the landings in this region consisted of 'small' fish. It was this area (and particularly the adjacent ports of Aberdeen, Hull, and Grimsby) which stood to gain by the closure of the small plaice grounds (and still more by the stocking of the Dogger Bank with transplanted fish), no less than the grounds in the 'Southern Bight'.

4. No other ground produced 200 tons of plaice, and the table shows that in the rest of the North Sea plaice formed for the most part an incidental and unimportant proportion of a catch of other fish.

1 These grounds are in the northern portion of the North Sea; and to these figures it would be necessary to add the catch of Scottish trawlers, which is not ascertainable. 


\section{CHAPTER $\times \mathrm{X}$}

\section{SHBIMPING AND PLAICE}

The 'shrimpers' on the east coast sail about the nursery grounds towing a beam-trawl or shank-net ${ }^{1}$ with a mesh which will catch a shrimp. It follows that they haul up on deck any flat fish met with of approximately the same length as a shrimp. They actually catch great numbers of 'baby' plaice, for wherever there are shrimps there will plaice fry be found. Jenkins (The Sea Fisheries, p. 196) recounts that as many as 10,400 young plaice have been taken on the Lancashire coast in a single two-hours' haul of the shrimp-trawl, which produced 32 quarts of shrimps (that is to say about $32 \mathrm{lb}$. weight) in September. And 'the average of some hundreds of experimental trawls extending over a period of seven years gave an average of 567 plaice caught per haul.' 2

These fish were $1 \frac{1}{2}$ to $4 \frac{1}{2}$ inches in length-that is to say, they were in their first and second summers. They were perfectly useless for human food. And though a certain number of them survived when they were returned to the sea if the trawl was hauled at half-hour intervals, and if the weather was not too hot, Johnstone ${ }^{3}$ was convinced that the destruction of young must be 'enormous' and was 'probably to be measured by the hundred million annually on the Lancashire coast'.

The writer is not aware that any exact scientific experiments have been made to test the destruction by shrimp trawlers inside the 10 -fathom line on our east coast. There is, however, little question that the destruction by shrimpers at Lynn, Boston, Leigh, Harwich, Grimsby, Gravesend, Whitstable, Yarmouth, Margate, East Swale, and other minor ports is great. The King's Lynn men, for instance, landed 665 tons of shrimps in 1913. King's Lynn shrimpers may, therefore, have caught over $19,000,000$ plaice fry, or even $400,000,000$ (of which the majority were killed) in a year. Now the national shrimp catch in 1913 was 3,662 tons, valued at $£ 67,060$. Allowing for underestimation it certainly cannot be said that the fishery compares in importance, from the point of view of food production, with the 35,000 tons of plaice, worth upwards of $£ 1,000,000$.

1 The shank-net has a wooden base instead of a foot-rope (Jenkins).

2 .Johnstone, British Fisheries. 3 Ibid. 
Do the operations of shrimp trawlers in the North Sea, either on the British or the Continental littoral, seriously diminish the stock of plaice? The question remains unanswered. Assuming it to be probable that the less valuable fishery damages another (and infinitely more valuable) fishery, what remedies can be applied ?

1. Since any mesh which will catch a shrimp will catch a young plaice, mesh regulation is obviously useless, though sometimes attempted-in Essex, for instance.

2. In the 'North Eastern' and 'Eastern' Sea Fishery Districts the net must be raised and cleaned at least once in half an hour. This regulation, if enforced, would certainly save many plaice fry. But enforcement is probably not easy. ${ }^{1}$

3. It has been suggested that shrimping should be prohibited altogether during seasons in which plaice (and other valuable) fry are most abundant on the shrimp-grounds. This might conceivably amount to stopping shrimping altogether. But as far as the North Sea is concerned it does not appear that the shrimp-trawling question has really been investigated systematically, and the proceedings of the last meeting of the International Council contain no reference to it.

Shrimp-trawling produces a hardy, handy race of open boat sailormen. Officials are rightly solicitous that their livelihood should not be interfered with. But the effect of shrimpcatching in the North Sea on the stock of plaice is a factor which is probably ascertaunable, and which should be ascertained.

Note.-Since this was written Professor Garstang has suggested to the writer that we should not only transplant plaice, but attempt to rear the plaice to be transplanted. If that idea materialized, the shrimp-trawls would be the obvious source of supply. Their plaice fry would be purchased from them alive, and the interest of the shrimpers in keeping " a little dab alive" would be maintained by the most effectual stimulus in the world.

1 A journalist who went out shrimping this summer (1920) and recounted his adventure in the Manchester Guardian said that the trawl was hauled about once an hour. 


\section{CHAP'TER XI}

\section{SIZE LIMITS AND OTHER REMEDIES FOR THE DEPLETION OF YOUNG MARKETABLE FISH}

To deal with the minority view first. If Garstang is correct; if the catching of fewer small plaice is to result only in overcrowding and shortage of food and degeneration, then, it is claimed, restrictions on catching fish will not improve the stock. The process would be less fish in the nets, more fish on the ground, less food to go round, more deaths from starvation. In that case the remedy for a depleted stock would be easy. The nations - or the premier fishing nation-would proceed with transplantation on a big scale, and all idea of international 'restrictions ' would be scrapped. As restrictions involve intrigues, delays, shuffles, ill-feeling, evasions, and very great expense, the nations may well hope that Garstang will prove his case.

Most people, however, have believed hitherto that it was not desirable to kill too many young fish on the nursery grounds ; and Atkinson, one of the most practical of our naturalists, has suggested that it could be prevented by making it illegal to land plaice ' ungutted', for no one will go to the trouble of gutting very small fish. As late as 1908 the trawler owners who gave evidence before Mr. Tennant's Committee suggested the advisability of closing the young plaice grounds to all trawlfishing during the time when the young fish predominated there. Messrs. C. Hellyer, Vivian, Bloomfield, Ward, Donnison, and Alward wished to effect this purpose by forbidding the landing or sale of plaice below 8 inches in length. 'They insisted, as did Sir G. Doughty, that to be of the least use this limit must apply to fish landed by all classes of vessels landing in Great Britain during the whole of the year. If exceptions were made, they said, the law would be impossible to enforce ashore, because it would be impossible to prove the previous history of under-sized fish offered for sale. Sir George Doughty told the Committee how he had helped to kill Lord Onslow's Bill in 1904, because it exempted sailing craft from the operation of the size limit, and thus practically ' nullified itself'. What the industry asked for was a size limit which should make it unprofitable to trawl the 'small-plaice grounds' during the four months of the year when fish below $S$ inches predominated in 
the catch-i.e. from mid-April to mid-August. It would not pay to send a ship out to catch only the one or two boxes of soles which could in these months be picked up on the grounds

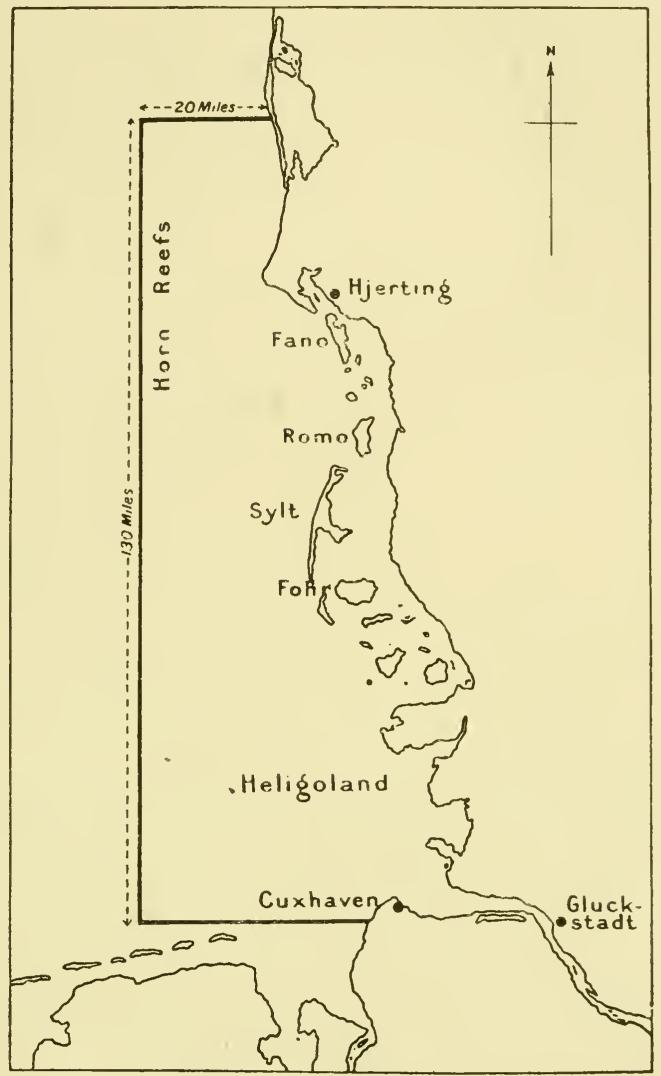

Fig. 4.-THE SIIALL PLAICE GROUNDS

Sketch-map showing the area which the trawler-owners hoped to close during the months of April to August by the imposition of a size limit in 1908 It is from the middle of April to the middle of August that small plaice predominate on these grounds.

south of the Horn Reef. It did pay to go for these soles if the skipper was sure of eight or ten boxes of small plaice to add as a makeweight. But if the small plaice were unsaleable-as they would be with a universal S-inch limit-no trawlers would work the ground. The result would be an automatic and almost complete closure of the small-plaice grounds during the period 
of maximum destruction, when they held hardly any fish other than these small plaice. For the rest of the year, when larger fish frequented them (or at any rate their offshore portions), they would not be closed.

The owners were agreed that, as scientific investigations were in progress, action should wait upon the report of the scientists; and in 1913 the scientists produced their report. They advised that no plaice under $20 \mathrm{~cm}$. ( 18 inches) should be landed between 1st October and 31st March, or under $22 \mathrm{~cm}$. ( $8 \frac{1}{2}$ inches) between 1 st April and 30th September. The halfinch of difference would never have survived the criticism of men experienced in landing plaice in bulk. Certain naturalistsnotably Masterman-have arrived at the conclusion that whereas a 9-inch limit would not make it unremunerative for a trawler to fish the small-plaice grounds, a 10-inch limit would do so. This is probably a point on which owners and skippers are much better able to decide correctly than research workers.

However, the war came. Fishing on the small-plaice grounds was restricted, if not extinguished; and it should now be possible (if it is not too late in 1920) to come to a definite conclusion as to the result of this closure.

\section{The International Council of 1920}

The International Council in 1920 published $^{1}$ two papers put in by foreign nations :

1. The Danes (Commodore G. F. Drechsel, Secretary to the Council, and Dr. A. C. Johansen) laid down this proposition : the large steam and sailing trawlers destroy great quantities of young plaice. For their protection it would be necessary to introduce an international size limit of $25-26 \mathrm{~cm}$. (say 10 to $10 \frac{1}{2}$ inches) and an endeavour should be made to introduce it. But inasmuch as a size limit so high as this would threaten "the very existence upon present lines ' of German and Dutch plaice fisheries, and as these deserving fishermen bring ' a great part of ' their plaice to market alive, they would fix the limit for a live plaice at 22 or $23 \mathrm{~cm}$. (say $8 \frac{1}{2}$ inches). (The reply ${ }^{2}$ of the British industry can be anticipated. Who is to say, when once it is dead, whether a fish of $8 \frac{1}{2}$ inches was or was not alive when it was landed?) With this reservation they recommend the

1 It failed to publish much valuable evidence submitted by the English Ministry of Agriculture. See p. 63.

${ }^{2}$ It is probably true that a size limit can be more cheaply and effectually enforced 'on the slab' than on the quayside. But the smallest fish are sold not to fishmongers but to fish friers, interference with whose trade is a matter to be undertaken only for the most unassailable reasons. 'They are the poor man's caterers par excellence in Great Britain. 
immediate imposition of a 10 or $10 \frac{1}{2}$-inch size limit to apply to all vessels. In addition to this the Danes wished to close the chief nursery grounds to steam trawlers only.

2. The Dutch, represented by their Inspector General of Fisheries, took a slightly different line. They calculated somehow that an 8 or $8 \frac{1}{2}$-inch limit would reduce the steam trawler catch by 1.2 per cent. only. Trawlers will go, they said, to the small-plaice grounds even if that limit is imposed, catch the small plaice, and throw them overboard. The Dutch are therefore in direct disagreement with the trawler owners most concerned, who were in 1908 unanimous that nothing of the kind would occur. And they are also in disagreement with that great authority Heincke, ${ }^{1}$ who stated, with the owners, that a size limit would make small-plaice catching an unprofitable enterprise not worth undertaking. The Dutch suggestion was that the whole European coast-line within the 10 -fathom line from the Skagerrak to Cape Grisnez-an area of 9,833 square miles nautical-should be closed to steam trawlers. "Of this area the portion south of the Borkum Flats (sày 265 square miles) is comparatively little fished by British vessels. That between the Skagerrak and Horn Reef produced plenty of large fish, both round and flat, right in to within five or six miles of the shore ; and the rest consisted of the 'small-plaice grounds'. In order to enforce this closure a blockade was to be made effectual by the use of the destroyer flotillas of the Powers. This closure was to apply to all'steam trawlers, but not to sailing trawlers; for whom the introduction of a size limit was suggested.

The Dutch think, curiously enough, that their suggestion may not be accepted. In that case they would substitute the imposition of the following size limits :

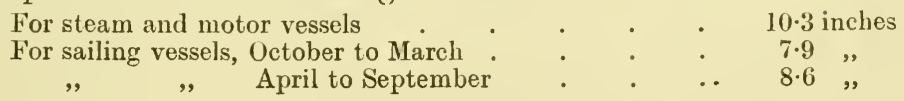

In Dutch territorial waters all trawling is to be forbidden except to sailing trawlers fitted with ' wells' -in which fish may be kept alive.

\section{The International Council's Plaice Committee}

The Danish and Dutch proposals went before the Plaice Committee of the International Council in London. It was composed as follows:

Chairman, Dr. Redeke (Holland).

Mr. Borley $\{$ (England).

Dr. Wemyss Fulton (Scotland).

Mr. Holt (Ireland).

M. Hamman (Belgium).

Dr. Johansen (Denmark).

Professor Joubin (France).

1 In his Report to the International Council, 1913. 
The English representatives proposed that before action was taken certain questions required to be settled, viz.:

1. What proportion of the stock is caught? What is the density of fishing? To answer these questions they proposed an experiment with 1,000 marked fish.

2. Do fish transplanted to the Dogger now grow as quickly as they did before the war?

3. What would be the loss of catch to English vessels if the area inside the 10-fathom line from the Skagerrak to Grisnez were closed? To answer this a naturalist should study the catch month by month.

4. What will be the actual effect of any size limit? To obtain an answer an accurate record should be kept of the plaice caught on all the principal North Sea grounds.

5 . What is the average size of plaice landed at " the smaller inshore ports', especially on the south and west coasts? And what would be the effect on their catch (about 1,200 tons) of (say) a $9 \frac{1}{2}$-inch limit? To answer this question, it was suggested, a special staff of fish measurers might well be employed at selected minor ports-a suggestion which is not likely to appeal to many students of fishery economics.

The Council of 1920 definitely decided that the proposals of their predecessors in 1913 needed to be reconsidered in view of the war. With this decision no one can quarrel. Before 1914 no one could have foreseen that the main problem-the effect of stopping men from catching plaice in particular areas-would ever pass from the region of conjecture to the region of fact. But by the war the grounds have actually been closed. On the assumption that the conditions before the war were fairly well known-as they were-it is obvious that it is possible to discover the conditions which now exist, and to assess the extent to which any change in conditions is due to the four years' closure. Never has Marine Science had such an opportunity. This the Council has recognized. It is quite correctly insisting that the effect of the war-i.e. the effect of the closure-on the stock of plaice should be ascertained.

It has decided that the old contention of the trawling industry is supported by the evidence available. That it is, in fact, desirable, whether directly or indirectly, to close the smallplaice grounds. It differs from the pre-war opinion of trawler owners and skippers in one respect. It has committed itself to the reservation that closures should probably be operative only as against steam trawlers and high-power motor vessels. On this point-if 'Science' maintains its position-the naturalist is likely to come into somewhat violent collision with the 
man of experience, who has always insisted that all fishing ships should be treated alike. ${ }^{1}$ British trawlers, however, can congratulate themselves that the executive head of the Fisheries Division of the Ministry of Agriculture will, as Chairman, have much to say to the decisions to be arrived at in March 1921 . Neither he nor his French and Norwegian colleagues are in the least likely to forget the main considerations.

These may be summed up as follows:

1. The Council exists to maintain and protect the supply of fish to the nations.

2. The supply of fish food will depend, in the main, on the operations of steam and motor vessels.

3. No restrictions on the operations of these (or other) vessels will be justifiable unless it can be shown definitely that they are likely to prevent depletion of the stock.

4. They will not be beneficial unless they can in practice be enforced."

5. They will not be properly enforced unless the people whose operations will be restricted can be induced to believe in them.

On questions of scientific fact the opinion of biologists-if checked in the light of experience-should be final. On questions of practicability experience must decide after weighing the data provided by Science. Practice can seldom sanction the absolutely desirable course. Good practice is, and always will be, a compromise between the best conceivable course, and that course which is attainable by an imperfect humanity.

The Council will fail or succeed in its ultimate object, accord. ing as it does or does not welcome and cultivate the collabora. tion of the men whose livelihood will immediately depend upon the soundness of its recommendations.

They may, if necessary, be converted. They will never be coerced.

1 Some people have suggested that lining should be allowed inside prohibited areas. But as a liner which is 'gutting' her fish fouls the bottom by . throwing offal overboard, she probably does as much harm as any trawler. 


\section{CHAPTER XII}

\section{THE APPARENT EFFECT OF THE WAR ON THE PLAICE FISHERY}

The Ministry of Agriculture in an 'inspired' communiqué published in the Fish Trades Gazette of 8th May 1920, claims that its statistics have established two facts :

1. That plaice are now more numerous than they were before the war.

2. That the average size has increased.

They base the first allegation on the fact that the average daily eatch per day's absence from poit compared as follows:

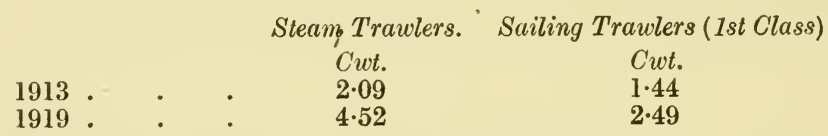

It is certain that the numbers of vessels fishing were smaller in 1919 than in 1913. Yet the catch was (in round numbers) :

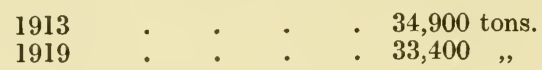

And these figures, ${ }^{1}$ so far as they go, support the contention that there are more plaice in the sea than there were in 1913. As to the alleged increase in the average size of fish, the trade categories-which are only very roughly reliable-compare as follows :

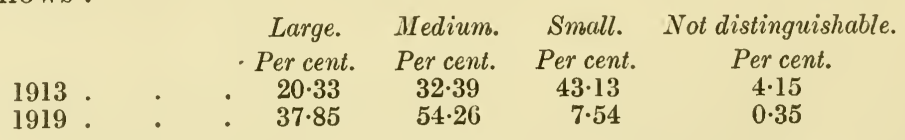

So that the trade has classified as 'small' very few of the plaice landed in 1919.

The Ministry draws attention to the fact that the smallplaice grounds off Holland and Dennark were not fished in 1919, and that their closure has affected the table. But they are convinced-and all North Sea fishermen are convinced with them-that the proportion of small plaice now landed is much less than it used to be.

1 But we do not know what grounds the 1919 plaice came from. 
In 1907 , for instance, 69 per cent. of the plaice landed ${ }^{1}$ at Lowestoft from the deep water midway between England and Holland (the C 3 area) were less than $11 \frac{1}{2}$ inches in length. In 1919 the corresponding percentage was about 3. "The small plaice which made up such a large percentage of the catch in 1907 simply were not on the grounds in 1919, their place being taken by larger fish. The probability is that the small plaice are crowded closer inshore. In general, it was found that the 1919 plaice were on the arerage over 4 inches longer than the pre-war plaice.'

All this the Ministry explained, we are told, to the International Council. But none of the 'direct and detailed evidence' thus submitted finds any place in the Council's Report for $1918-20 .^{2}$

Of the experiments which the Ministry is carrying out, by far the most interesting is a repetition of Garstang's transplantation of young fish to the Dogger Bank. The Dogger is now densely populated with plaice. Young fish turned adrift on it will find less room on the bottom, and less food. What effect will this have on their growth?

The answer will be most interesting. But, even if their growth on the Dogger is for the time being retarded, it will still be quicker than on the small-plaice grounds, and the careful planting of five million young fish every year would have results which would easily be assessed by simultaneous marking experiments.

For the rest, money is to be spent on measuring fish at several of the smaller ports on the south and west coasts in order to ascertain the effect of a size limit on the small catch of plaice landed there $;^{3}$ to find out whether migrant plaice make longer or shorter journeys now that their feeding-grounds are comparatively crowded; and whether overcrowding has affected their rate of growth, and their condition generally. It is further proposed to calculate the number of eggs produced in the main spawning area; it is hoped thus to be able in the future to

1 But the small plaice from the area were only $39 \cdot 46$ per cent. of the 2,163 tons landed from this area at all ports.

2 For the comparative interests of Great Britain, Denmark, and Holland in the plaice fishery, see p. 31, The European Catch.

3 The English plaice catch (including steam trawlers' catch) was:

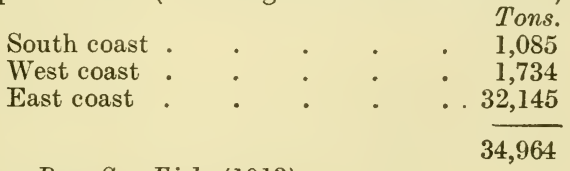

v. Table I (a), Ann. Rep. Sea Fish. (1913). 
predict 'good years' and 'bad years'. If, as is likely, the principal destruction of a brood takes place after the eggs have been cast adrift, the object may not be attained by this means, though the investigation will doubtless be useful.

In a second communiqué, published in the Fishing News of 17th July 1920, the Ministry of Agriculture further discusses its investigations, and the first two cruises of its research vessel, the J. and S. Miles. The first of these cruises was a trawling expedition along the line from the Leman Banks to the Haaks Lightship, followed by a search for small plaice on the Dutch coast. The second was a transplantation experiment.

The Ministry asks the question: Why are the plaice caught now bigger than they used to be before the war?

Is it because the fish have had time to grow? The Ministry hesitates to accept this explanation. A quite moderate-sized plaice, they say, before the war was five or six years old. And there are now very few small plaice among the marketable fish. It is in the official opinion not probable ${ }^{1}$ that the plaice have grown to a larger size in a shorter time, because there are more plaice, and so there must also have been increased competition for food. Moreover, the Danish investigator Johansen has found that plaice of a given size are now older than formerly-and that their growth is actually slower than it was before the war. As a possible but not very helpful alternative, the Ministry suggests that on some grounds the distribution has changed' large plaice replacing smaller and younger ones'.

The mine-fields have protected medium and large plaice from capture. Vessels have been unable to fish among the mines. The grounds have been closed. Have the surplus full-grown plaice from these closed grounds migrated to the other feedinggrounds and so re-stocked the North Sea? The question remains unanswered, as does the question: Where are the small fish?

The J. and S. Miles is seeking for answers to both questions.

1 But it is at least possible that a number of fish have, in the words of Hérubel, 'peacefully grown old,' and that this 'first reserve' will rapidly be exhausted, as has been the universal experienee on virgin grounds. Moreover it is not safe to draw definite conclusions, on the data available, as to the supply of food for the fish. The food supplies vary enormously from year to year, and their fluctuations are governed by conditions other than the inter-tribal bickerings of mankind! 


\section{CHAPTER XIII}

\section{THE TURBOT AND TURBOT CULTURE}

\section{The European Catch, 1913}

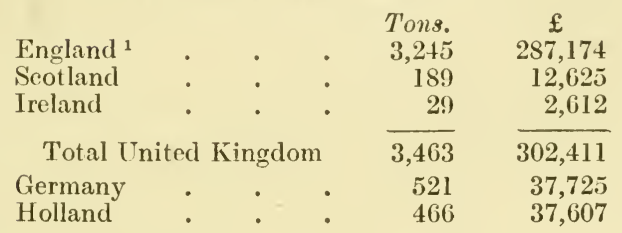

\section{The British Catch (Analysed)}

The main catches were landed at the following ports :

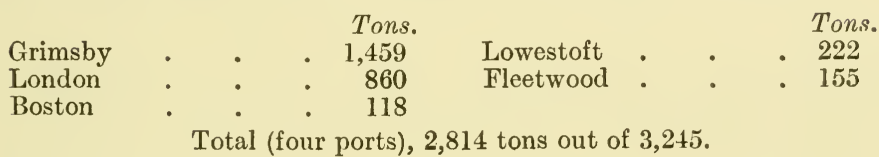

The London landings (860 tons) were made chiefiy by Hull vessels. The remaining ports of England landed about 431 tons between them.

\section{Distribution among the Chief Fishing Grounds}

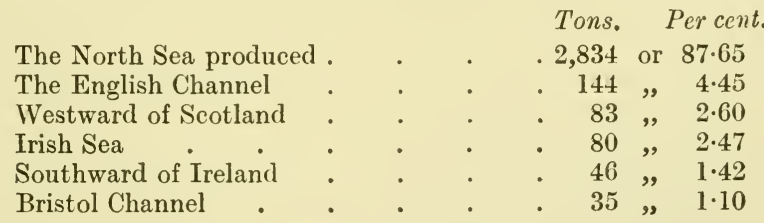

No figures available give the details of distribution in the North Sea, but most of the turbot certainly comes from south of the Tees-Skaw line.

1 In 1920 the landings were :

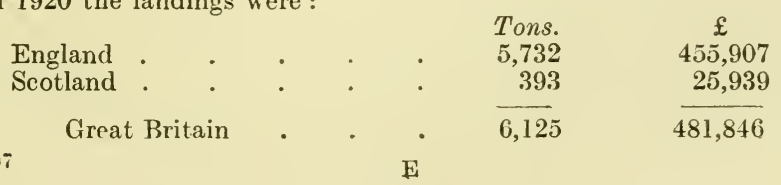




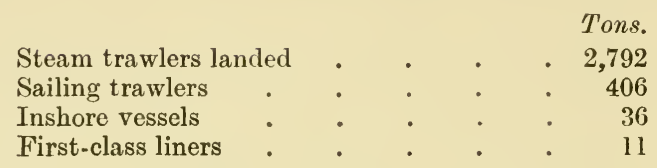

The turbot is, therefore, mainly a steam-trawler fish, and has failed to interest some 'longshore' naturalists. Yet 88 per cent. of the catch in the North Sea is estimated by Hjort (Depths of Ocean, p. 451) to come from comparatively shallow banks at depths between 10 and 30 fathoms, though they are caught also at what he calls the "medium depths' (25-50 fathoms).

\section{Fluctuations in the Catch in the North Sea}

East coast landings by first-class English vessels in the North Sea have varied as follows:

\begin{tabular}{|c|c|c|c|c|c|c|c|}
\hline Steam trawlers & - & $\begin{array}{l}1908 . \\
\text { Tons. } \\
2,527\end{array}$ & $\begin{array}{l}1909 . \\
\text { Tons. } \\
2,079\end{array}$ & $\begin{array}{l}1910 . \\
\text { Tons. } \\
1,824\end{array}$ & $\begin{array}{l}1911 . \\
\text { Tons. } \\
1,937 \\
225\end{array}$ & $\begin{array}{l}1912 . \\
\text { Tons. } \\
2,396 \\
292\end{array}$ & $\begin{array}{r}1913 . \\
\text { Tons. } \\
2,552 \\
276\end{array}$ \\
\hline \multirow{2}{*}{ Sailing vessels . } & . & 289 & 262 & 232 & 225 & 292 & 276 \\
\hline & & 2,816 & 2,341 & 2,056 & 2,162 & 2,688 & 828 \\
\hline
\end{tabular}

So that the turbot, which is the trawlerman's most valuable prize, and which is, presumably, hunted as indefatigably as any fish which swims in the North Sea, showed no sign at all, in this short cycle of six years, that it was being ' fished out'.

\section{Life-History}

Holt (Journ. M.B.A., 1891-2, p. 399) hatched the eggs ${ }^{1}$ in 1892, and first described the larvae, which, however, died within a few days. And Fulton and Dannevig carried the larvae through the post-larval stage at Dunbar to the disappearance of the yolk-sac on the seventh day. They remarked on the great hardiness of the fish, and were hopeful that it might eventually be reared right through the critical period. The spawning grounds were, however, far distant from Dunbar. Those discovered in the North Sea are situated in the extreme south-west at 5 to 20 fathoms; and others have been located to the south and west of Britain, and in the Mediterranean, in relatively shallow water. In the Mediterranean (Marseille) larvae have been caught on the 2nd March.

It was left to French scientists to carry on the investigations in laboratories nearer to the big spawning grounds. FabreDomergue and Biétrix tried, and failed, to hatch the eggs at

1 Turbot eggs measure about $\cdot 0.4$ inch in diameter, i. e. $1,057,000$ to the fluid quart. 
Concarneau in Brittany. Then in 1905 Malard and Dantan at St Vaast-la-Hougue succeeded in hatching turbot, but failed, like Fulton, to carry the fry through the critical period immediately following the disappearance of the yolk-sac. Finally, in 1907, Dr.R.Anthony, Assistant Director at St. Vaast, triumphed, and he described his method to the Fourth International

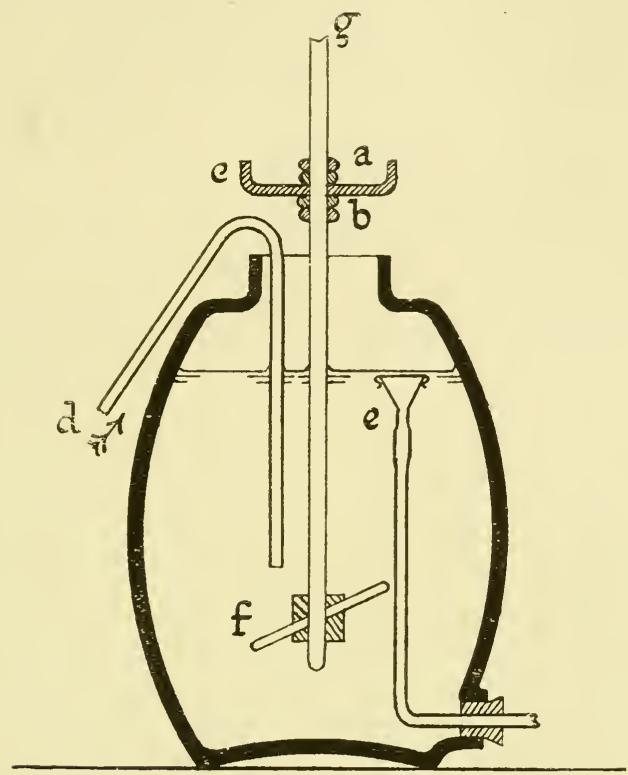

Fig. 5. APPARATUS FOR HATCHING TURBOT. (Modification of apparatus of Fabre-Domergue and Biétrix.)

$a$ and $b$, wads of cotton to prevent oil entering barrel along vertical glass rod $g ; c$, upturned cover which serves as dust shield; $d$, inlet pipe ; $e$, outlet pipe with screened funnel entrance; $f$, revolving disk; $g$, vertical glass rod carrying disk.

Note. - The capacity of the glass barrel is $\mathbf{4 4}$ quarts. The disk is driven by a small hot-air motor of $\frac{1}{40}$ horse-power. The top of the funnel at $e$ is covered with very fine silk, which allows the passage of water but not of larvae. The opening of the funnel is the size of a five-shilling piece, and the 'flare' decreases intensity of the current, which, if it were too violent, would carry the larvae out of the barrel.

Fishery Congress ${ }^{1}$ in 1908 . In February he procured ten adult turbots and confined them in the large hatching basins at St. Vaast. He notes that it is at present impossible to distinguish between males and females-while they are alive-and that turbot may be immature if they measure less than 15 or

1 The 'Cultivation of the Tur bot,'Bull. U.S.B.F., vol. xx viii, part 2, p. 861. 
16 inches. At the end of a few weeks the wild fish began to feed. They were then given very short rations-i.e. a bit of plaice about as big as the hand once a week to each fish. Anthony noted that overfeeding of the fish in previous experiments had probably been one reason why turbot had so often refused to spawn in captivity. To keep the basins clean a conger eel and a dogfish were kept in the basins as scavengers.

The first eggs were found on the 18th July; and the fish spawned again on the 18th, 21st, 28th, 29th July, and on 3rd August. There were 'thousands and thousands' of eggs, all normal and normally fertilized. A certain number of eggs were transplanted to 10-gallon glass barrels (Fig. 5) in which the water was kept in motion by a revolving disk driven by a small one-fortieth horse-power hot-air motor. This was a modification introduced by Biétrix and Fabre Domergue into an apparatus invented by Browne of Plymouth, who agitated his water by means of the rise and fall of a plunging disk. Part of the water was renewed for ten minutes several times a dayand dead eggs and other matter were cleared out from the bottom. The best temperature was found to be $59^{\circ} \mathrm{F}$. to $68^{\circ} \mathrm{F}$., the latter being the highest limit of safety. The eggs hatched out between the sixth and eighth day after spawning-the same period which was observed in this country by Holt, and by Fulton and Harold Dannevig at Dunbar.

Two or three days after hatching the larvae were fed with live 'plankton' collected at sea, and carefully sifted in the laboratory. Plankton was placed in the barrels once a day and in great abundance; the revolving disk of course maintained a constant current in the barrel, and kept the plankton alive, so the young fry always had their natural food at hand directly they began to feed, as they did long before the yolk-sac was absorbed.

The yolk-sacs-finally disappeared on the fourteenth or fifteenth day. It is noticeable that at Dunbar (where the larvae were not fed) this stage was reached on the seventh day. This suggests to the writer's mind that the Dunbar fish died of starvation. Probably the yolk-sac does not contain in itself enough food to carry what trout-breeders call ' alevins' through the larval stage. Lebour notes that all the 'large-mouthed' flat fishes, soles, turbot, brill, dabs, and plaice (?), start feeding on copepods almost as soon as they are hatched. Probably the contents of their sacs must be supplemented by other foodin the case of turbot within a day or two after hatching-or the fry will be weakly by the time the yolk has gone. In other words, the babies must be weaned gradually; in Scotland they 
were weaned suddenly. Dr. Anthony's fry-thanks to his early feeding-came through to the eighteenth or twentieth day, by which time they were quite hardy and able to look after themselves, with a loss of only 10 per cent.

Any one who is familiar with the Rhode Island State Lobster Hatchery at Wickford will recognize that Dr. Mead and Mr. Barnes and their colleagues have merely applied on a big scale the principle which Dr. Anthony has worked out in the St. Vaast laboratory. In place of glass barrels they have floating boxes 10 feet square; in place of the revolving disk a $4 \frac{1}{2}$-foot propeller; in place of the little hot-air motor, a full-blown petrol engine. But the principles are identical-constant motion of the water; careful feeding with floating food.

If by the Wickford or any other method turbot larvae in captivity can be ensured a good circulation of water, and if a suitable form of 'infant's food ' to supplement that in the yolksac can be found, there is little doubt that Dr. Anthony will be the founder of modern turbot culture on a big scale. Dr. Anthony is confident of devising an apparatus and a method of feeding; and, as he says, the turbot is such a valuable and such a hardy fish that it will almost certainly repay cultivation. Dr. Anthony's paper suggests one cause which may contribute to the wholesale catastrophes which seem to overtake broods of marine fishes in particular years. Young turbot must find natural food very soon after hatching, and Dr. Lebour finds that they probably prefer copepods like Temora and Calanus and the free-swimming larvae of barnacles to all other food. Normally they spend this period near the surface from the 1st July to the 15th September, a season of the year when, on the French coast of the channel, storms are rare and the plankton is undisturbed. What would be the effect of a week or two of really bad weather, with the water heavily charged with ooze and sand, on the shallows? Would it mean that planktonic life was driven to mid water and that the little turbot at the surface would be short of rations-and could similar results follow in the case of other species from similar changes in weather or temperature? The writer offers no answer. The answer depends on a knowledge of, for instance, the life-history of the copepod Calanus (which is at once the favourite food of the baby turbot one-tenth of an inch long and of the seventy-foot finner whale)-knowledge which the writer does not possess. ${ }^{1}$ But he can say that a trawler or whaler captain who actually saw a scientist engaged in working out the biology of Calanus or studying with a microscope one of the plants on which

1 But see below, pp. 193, 194. 
Galanus feeds, would find it a little difficult to trace the connexion between these investigations and his own livelihood. The " practical man ' in him would revolt against this unpractical waste of time, and the 'practical man ' in him would be utterly and ineffably mistaken!

But hunters of fishes and whales are trained observers, quick to recognize cause and effect. It should be no difficult task for Science to explain to them the chain of interdependence which binds together all creatures in the sea. The fishermanproperly approached-will listen readily enough. But he cannot listen so long as research workers address themselves always to each other, and never to the untrained multitude outside their sacred circle. And he will listen much more readily if he can see an experiment like Dr. Anthony's-including the feeding of the fry, and the collection of the food. To do him justice he has clamoured for a chance to see these things for many years. But unfortunately Plymouth is a far cry from all the big fishing-ports. There should be some place where experiments like Anthony's could be demonstrated within a few hours' run of every big fishing-port in the kingdom.

McIntosh, on p. 7 of British Food Fishes, has described how in 1884 'the earnest and genial Professor E. E. Prince' was able to arouse the enthusiasm and collaboration of fishermen by letting them see and understand his work at the Marine Laboratory at St. Andrews, and especially his work among the floating eggs. "Many of them were by and by provided with earthernware jars which they took to sea, and in some instances were successful in bringing to the laboratory fertilized and floating eggs of forms not yet examined.' And when it came, in 1885, to asking Oxford University to support the foundation of the Plymouth Laboratory, Dr. McIntosh "was able to adduce this fact as an instance of the effect of such institutions even on the fishing population'. What was true of the fishing fraternity in 1884 is even more true to-day. They lack not hunger for knowledge but opportunities of satisfying their appetite. This is more especially true of the men who work out of the great ports of Grimsby and Hull. It will also be true of the port of Fleetwood if the Piel laboratory is allowed to close down. Aberdeen is more happily situated, as its owners and skippers can always keep touch with Dr. Fulton and his colleagues. 


\section{CHAPTER XIV}

\section{THE SOLES}

The European Catch, 1913

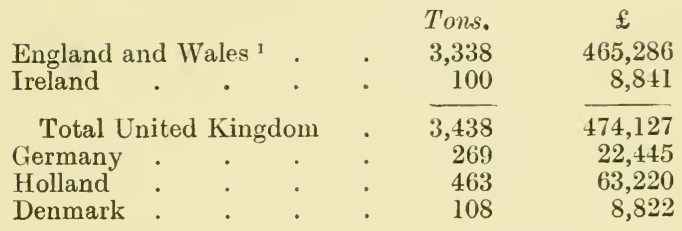

\section{The British Catch (Analysed)}

The main catches were landed at the following ports :

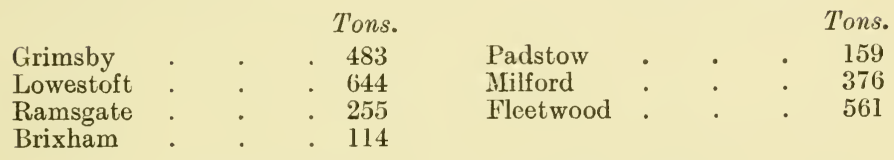

Total seven ports : 2,592 tons out of 3,338 .

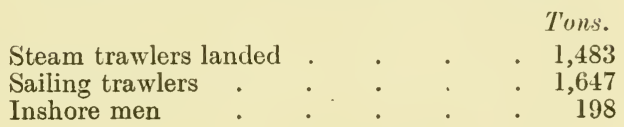

The catch of soles was distributed as follows :

I. North Sea.

Steam trawlers.

Sailing trawlers.

Inshore vessels . $\quad 50$

Total . . ${\overline{1,506^{2}}}^{2}$

III. Bristol Channel. Tons.

Steam trawlers. . 178

Sailing trawlers. $\quad$. $\quad 379$

Inshore vessels . . 7

Total . . . $\overline{564}$
II. Irish Sea.

Tons.

Steam trawlers . . $5 \tilde{5} 1$

Sailing trawlers . . 126

Inshore vessels . . . 56

Total . . . $\overline{733}$

IV. English Channel. Tons.

Steam trawlers . . 28

Sailing trawlers . • 238

Inshore vessels $\quad \cdot \quad \cdot \quad 86$

Total . . . $\overline{352}$

1 In 1920 the landings were :

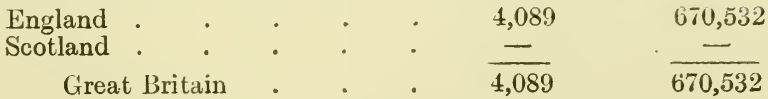

2 Uf which only 22 tons came from north of the Tees-skaw line. 


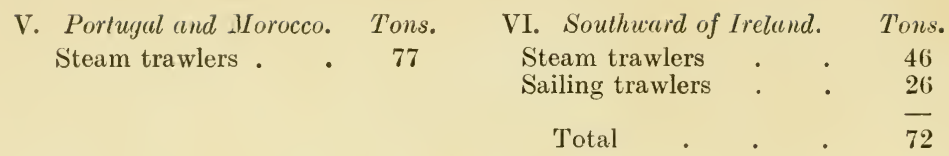

The soles, therefore, were not principally the prey of steamers but of men 'in sail'. They were caught chiefly at depths between 10 and 30 fathoms in the North Sea (south of the Dogger Bank), the Irish Sea, the Bristol Channel, and the English Channel. They are rare. They are accordingly expensive. And they are (in exact antithesis to the coalfish) essentially a luxury fish, and food for rich men.

It is only on the southern trawling grounds down along the coasts of Portugal and Morocco (where soles form about 15 per cent. of the catch of the hake boats) that the big deepsea vessels set forth with the idea of catching soles as one of the main objectives. But on any grounds which they frequent a few boxes of soles may make all the difference between profit and loss on a voyage, and the tribe is of the utmost economic value to all classes of fishermen who fish in those regions.

\section{Fluctuations in the Catch}

From 1906 to 1913 the catch varied as follows :

$\begin{array}{ccccc} & \text { North Sea. } & \text { Trish Sea. } & \text { Bristol Channel. } & \text { English Channel. } \\ \text { Tons. } & \text { Tons. } & \text { Tons. } & \text { Tons. } \\ 1906 & 1,983 & 156 & 342 & 350 \\ 1907 & 1,893 & 234 & 283 & 356 \\ 1908 & 1,760 & 294 & 513 & 323 \\ 1909 & 1,499 & 394 & 514 & 327 \\ 1910 & 1,203 & 556 & 554 & 276 \\ 1911 & 1,254 & 705 & 559 & 326 \\ 1912 & 1,576 & 713 & 686 & 325 \\ 1913 & 1,506 & 734 & 564 & 361\end{array}$

It will be noticèd that 1910 saw low-water mark in the sole fishery in the North Sea and in the English Channel ; as it did in the case of the plaice fisheries in the same waters. After that year there was in the case of each species a recovery. In the case of plaice at least this was not apparently due to the fact that more vessels were fishing, as the average daily catch per trawler also improved in 1911 and 1912. ${ }^{1}$

Is it possible that the fluctuations of the sole were due less to the efforts of fishermen than to some change in oceanic conditions? This is no place to attempt an answer, but it is suggested that inquiries should be made along this line.

1 See statement on p. 40, Chapter VII 
P L A T E I I I

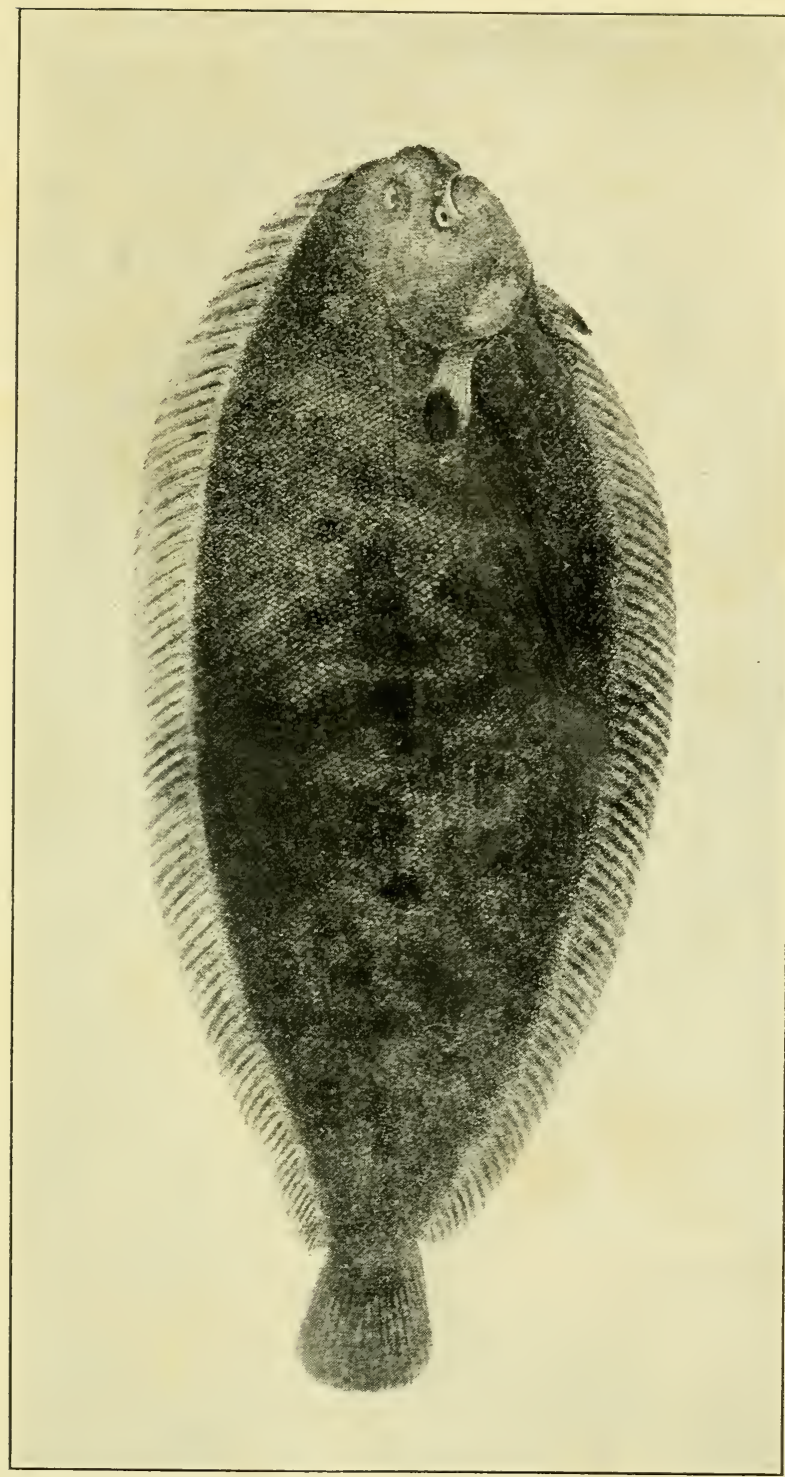

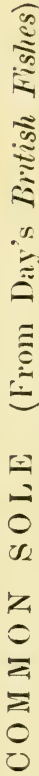

P. 72 



\section{Life-History of the Soles}

The Influence of Temperature. The soles-like the hakeare essentially 'southern' fishes. Hjort (Depths of Ocean, p. 452) notes that on the shallow coast banks and on the Dogger down to 20 fathoms the bottom temperature of the North Sea rises to $54^{\circ} \mathrm{F}$. at least; on the other hand, below 21 fathoms the summer and winter temperature is very much the same-about $43^{\circ} \mathrm{F}$. He suggests that down to 21 fathoms the sole may find in the North Sea shallows water of approximately the same temperature as it is accustomed to in deeper waters off the Atlantic coast of Europe. If that is so, and if temperature is the deciding factor, it is clear that any circumstance which prevented the water on a particular bank from rising in summer to $54^{\circ} \mathrm{F}$., or which postponed the rise of temperature, might either prevent the soles from frequenting that shallow altogether or might make their visit abnormally late. Conversely an exceptionally early summer at the bottom might produce unusually large congregations of soles. And if soles frequent these shallows for spawning purposes the effect on the brood of the year might be very great. By far the most prolific grounds in the North Sea are situated at from 10 to 20 fathoms. $^{1}$ But the French deep sea expeditions have caught soles at 130 fathoms off the Atlantic coast of Europe.

The Spawning Grounds. The eggs in the North Sea have generally been found in depths between 8 to 20 fathoms near Norderney from April to August, May being the principal month. Spawning also takes place in the Channel; off Plymouth soles spawn in the earlier months ${ }^{2}$ of the year; and in the Irish Sea from May to July. It has long been believed by fishermen-and is apparently now believed by Science-that the main spawning-grounds are very much farther to the south; and the spawners in our home waters are doubtless wanderers. It is important to notice that when 500 soles were placed in St. Andrews Bay in 1897 they apparently spawned in due course. ${ }^{3}$ Eggs ${ }^{4}$ have been found off Marseille as early as February and off the east coast of Scotland

1 The exact figures in 1913 were :

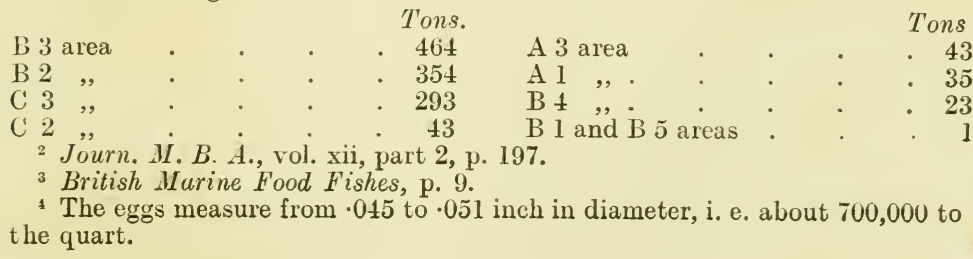


as late as August, and these facts seem to indicate that the journeys of the spawners and the time of their spawning depend upon temperature. ${ }^{1}$ Depth is not, apparently, an important factor, as soles have spawned freely in the shallow tanks at Plymouth.

For some reason, perhaps because they overfed them, the French investigators Fabre Domergue and Biétrix in 1905 failed to induce their captive soles to spawn at Concarneau, but they collected eyed eggs from the sea, hatched ${ }^{2}$ them and reared the fry through the larval and post-larval periods to the stage at which they began to forage for their own food. It is now certain that soles could be transplanted, and practically certain that they could be hatched and reared on a commercial scale; and the tribe is so hardy and so valuable that 'sole breeding' is quite likely to be a serious business proposition within a few years. Meanwhile of course the development is well known. The eggs of the common sole are about 0.04 to 0.05 inch in diameter. They are transparent and provided with small oil globules. The eggs are hardyas is the fish at every stage of its existence-more so (even) than the plaice. Meek gives the approximate period of incubation as 10 days (temperature not stated), and McIntosh in 1897 noted that the yolk-sac (temperature was not stated) was practically absorbed by the ninth day. The fry are then one-tenth of an inch long. The fish begin to turn over on to their right side at about one-fifth of an inch long, and are real flat fish at two-fifths of an inch.

The fry in the Thames Estuary are said to be $2 \frac{3}{4}$ to $3 \frac{1}{4}$ inches long by their first October. Cunningham says that the fish reach 6 to 7 inches in their first year, Fabre Domergue that they are as much as 12 inches long at the age of two years; and Johnstone, that they are mature when they are about 12 inehes long. All these remarks apply to the common sole.

Dr. Lebour states that the young soles at Plymouth have been found to live principally on the free swimming larvae of barnacles (Balanus), and on copepods which live on the minute plants in the upper layers of all seas. Young soles apparently take copepods-they prefer Temora to all others-almost as soon as they are hatched.

The Thickback (Solea variegata), seldom exceeding 9 inches in length, is a deep-water form. The French expeditions found it at 168 fathoms. Very little information is available as to

1 British Marine Food Fishes, p. 394.

${ }^{2}$ Le Développement de la Sole, 1905 ('Travail du Laboratoire de Zoologie maritime de Concarneau). 


\section{PL A T E I V}

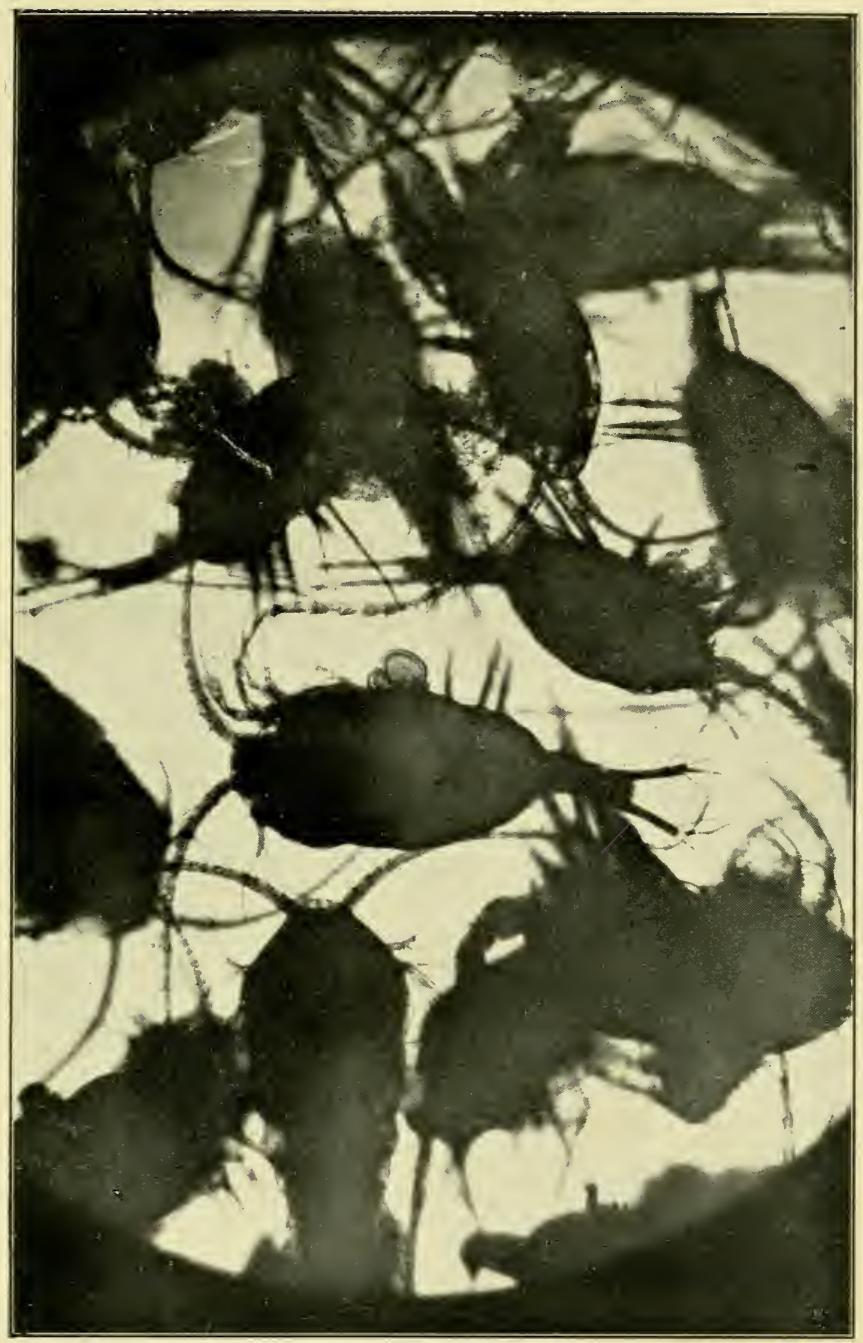

TEMORA Magnified 20 diameters

A favourite food of young mackerel and soles, lemon soles, brill, whiting, turbot, and mackerel.

(Photograph by Mr. A. Scott.) 

its habits, but it is said to spawn to the south-west of the British Islands and in the Mediterranean from February to July, and the larvae are (naturally) smaller than those of the common sole. It is caught at from 20 to 150 fathoms. It is too small to be of great economic value. Most of the post. larval fry have been found in water more than 20 fathoms deep. A fry of 1.2 inch, caught in 29 fathoms off the Eddystone in 1914 by R. S. Clark (5th March), is the smallest 'adolescent' fish of this species actually recognized. It was presumably at least eight months old. Lebour finds that the larvae (caught in April off Plymouth) were feeding on much the same food as the common sole.

The French Sole (S. lascaris) or Sand Sole does not usually exceed 14 inches. It is very rare ${ }^{1}$ in the Mediterranean, and inhabits the south-west region. The fry have been taken in 1920 close inshore at the entrance to Plymouth Sound in September. They measured from one-fifth to two-fifths of an inch long. The spawning period is June to August. A specimen reared at Plymouth by R. S. Clark measured 0.3 inch in the middle of September and 0.6 inch at the end of October, when it went to the bottom. It grew 0.3 inch in four weeks. The food resembles that of the other soles.

It is fairly evident that much research remains to be done on our commercial soles, particularly in the direction of rearing the young, transplanting the small fish, and cultivating them generally.

It is also important to discover the causes which affect their migrations; and that the work of French experimenter:s should be made known to English readers.

1 P. Gourret, Les Pêcheries ct les Poissons de la Méditerrunée (Provence) 1894. 


\section{CHAPTER XV}

\section{THE HADDOCK PROBLEM}

\section{The European Haddock Catch (Analysed)}

The comparative catch, ${ }^{1}$ so far as it is known, was as follows in 1913 :

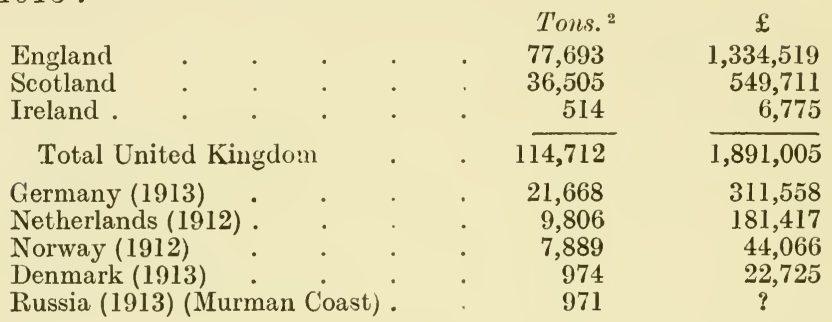

About 71.8 per cent. of haddock came from the North Sea and they formed about $45 \cdot 1$ per cent. of the North Sea catch in 1906. British fishermen landed very much more haddock than the rest of their fishing neighbours put together.

\section{The British Catch (Analysed)}

Of the English catch the following ports landed over 1,000 tons and the total catch was as shown:

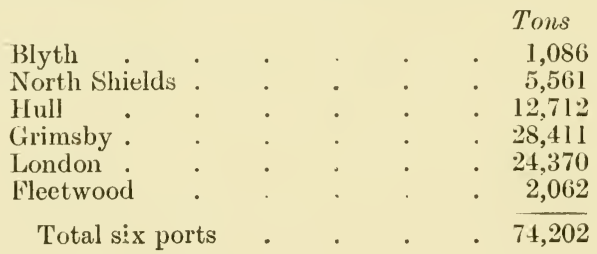

1 In 1897 the quantity was 127,445 tons. In 1920 the landings were :

$$
\begin{aligned}
& \text { Eingland . . . . . . } \quad 136,580 \quad 4,193,083 \\
& \text { Scotland . . . . } \quad 59,996 \quad 1,584,119 \\
& \text { Great Britain . . . } \overline{196,576} \quad \overline{5,777,202}
\end{aligned}
$$

\begin{tabular}{|c|c|c|c|c|c|c|c|}
\hline 1914 & 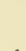 & 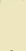 & $\begin{array}{l}\text { Tons. } \\
66.856\end{array}$ & 1917 & . & . & $\begin{array}{l}\text { Tons. } \\
43.951\end{array}$ \\
\hline 1915 & • & . & 59,791 & 1918 & . & . & 58.077 \\
\hline 1916. & . & . & 39,540 & 1919 & . & . & $106,55]$ \\
\hline
\end{tabular}

2 Subsequent English catches have been : 
The remaining ports in England landed between them 3,491 tons only, and no one of them as much as 1,000 tons. Of these 3,491 tons, no less than 3,244 were landed at Sunderland, Hartlepool, Scarborough, Boston, Plymouth, Cardiff, Swansea, and Milford.

These figures show that the haddock industry was mainly a steam-trawl industry in England.

Haddock in 1913 formed $18.59^{1}$ per cent. of the English catch of bottom fish ; 61 per cent. came from the North Sea, nearly 20 per cent. from Iceland, 10 per cent. from Faeroe, and 3 per cent. from the westward of Scotland.

In Scotland steam trawlers landed 32,258 tons (out of 36,505 ), ${ }^{2}$ and of these 28,554 tons were landed on the east coast.

The chief landings by clistricts were :

\begin{tabular}{|c|c|c|c|c|c|c|c|c|}
\hline Aberdeen & listrict & . & . & . & • & • & . & $\begin{array}{l}\text { Tons. } \\
19,868\end{array}$ \\
\hline Leith . & . & • & . & . & . & 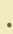 & . & 6.165 \\
\hline Montrose & . & . & . & . & . & • & . & 2,439 \\
\hline
\end{tabular}

Of the total Scottish catch, 75 per cent. came from the North Sea, nearly 14 per cent. from Iceland and Faeroe, and 7 per cent. from the Western Grounds.

\section{Traditional Fluctuations in the Catch}

Bertram, writing in 1873 and 1885 (Harvest of the Sea), says that this 'prime fish' has always been popular. With reference to what follows here it is worth recording that he had 'been reminded of a time in 1790 when three of these fish were sold for $7 s .6 d$. in the Edinburgh market'-and that it has ' more than once become scarce ' ${ }^{3}$

Meek has discovered in the Transactions of the Royal Society, 1792, a paper by the Rev. Cooper Abbs, which describes the failure of haddock on the north-east coast here referred to. The winter fishery was a failure, and the scarcity continued for the next three years. Mr. Abbs was told by the masters of vessels trading to Archangel that at the end of July 1789, between $68^{\circ}$ and $69^{\circ} \mathrm{N}$., "in the Barents Sea the sea was found to be covered with large haddock and coalfish all dying at the surface. Their air bladders were much inflated.'

In 1906 it was 33 per cent.; in 1910 it was 23 per cent.

2 In 1919 the catch of haddock in Scotland was 45,197 tons, of which steam trawlers landed 33,748 ; motor liners, 8,808; sailing liners, 2,623.

3 The east coast fishermen maintain that a spell of heavy weather from the north-east is necessary to 'drive the haddock inshore'. 
Meek, in discussing the incident, suggests as possible that ' in the summer of 1789 the summer deep-sea quarters of the haddock and other fish were flooded by Arctic water', and that the observations of the skippers ' referred merely to a local manifestation'. He thinks 'the smaller haddocks of more southern latitudes may have been equally affected without their death bringing them to the surface'. The young fish escaped, he thinks. Whatever the explanation, the fact of the scarcity is interesting, and may have some bearing on the modern problem. Thirteen years before this catastrophe, according to Pennant, in 1776 haddock were so plentiful a mile off Scarborough that three men long-lining in a coble could catch two tons a day.

Up to the year 1870 again haddock were common off Mevagissey. That year they left Cornish waters. Again, ' in the nineties' haddock were plentiful in the Irish Sea and disappeared in a few years. The reason for this disappearance is not known. All this was before the days of statistics. But there is some evidence that fluctuations occurred long before the steam trawler could be made the scapegoat for a shortage.

\section{Life-History}

The haddock lives and spawns for choice on soft muddy flats covered with 25 to 50 fathoms of water. Given these conditions it does not appear to be repulsed by cold. It is common, for instance, on grounds of this nature both off Iceland and in the Barents Sea. ${ }^{1}$ The main spawning-grounds are in the northern portion of the North Sea especially north of longitude $58^{\circ} \mathrm{N}$. There is little spawning south of $56^{\circ} \mathrm{N}$. (Russell). Other spawning grounds are situated on the south and west coasts of Iceland. round the Faeroes, at Rockall, north and west of Scotland, and west of Ireland, always inside the 100 fathom line. The number of eggs varies with the size of the fish, but the American ${ }^{2}$ fish-culturists (who handle many thousands of haddock) give the average as about 100,000 per fish.

The spawning season is from January to June, and is at its height in March and April. The eggs are one-seventeenth of an inch in diameter, ${ }^{3}$ and are delicate and easily damaged. They are slightly glutinous, and have a tendency to form into small lumps during hatching. They hatch in fifteen days at $37^{\circ} \mathrm{F}$. and in thirteen days at $41^{\circ}$. The yolk-sac is completely absorbed in ten days at a temperature of $41^{\circ}$. Holt in June has hatched eggs in six days.

1 Hjort, Depths of Ocean.

2 Manual of Fish Culture, p. 223.

3 i. e. 058 inch. About 347,000 eggs are contained in a quart. 
The fry remain at the surface during May, June, and July.

During this time they drift far away from their spawning grounds, and are, unlike the coll, never found in the southern part of the North Sea, the Channel, the Kattegat, or off the north coast of Norway. But 'Schmidt found in the Atlantic over great depths large fry near the surface' (Meek). They then go to the bottom at depths of 25 to 50 fathoms. At this time they average 1.18 inch.

During the first summer they grow very quickly-nearly an inch a month. By September they are $2 \frac{1}{4} 1$ to $4 \frac{1}{2}$ inches long, and in December (at seven to eleven months old) $5 \frac{1}{2}$ to $7 \frac{1}{4}$ inches. They first begin to be caught on hooks in July when they are about 4 inches long, and something less than five months old. During winter of course the growth is much slower. ${ }^{2}$ Haddock less than 9 inches seldom occur in the south of the North Sea. Heincke considers that maturity is reached after the third year.

In some years American spawn-takers find comparatively few ' ripe' haddock on the grounds. Thus in 1913 the Boothbay spawn-takers collected 100 million eggs ; next year on the same grounds they obtained only six million eggs of "poor quality'; in 1915 they collected $3 \frac{1}{2}$ million also of "poor quality' ; in 1916 (February) 'there was an entire absence of haddock in spawning condition'; on other grounds, however, the Gloucester fishermen found plenty of ripe fish. But the variations were enormous from year to year. Is there here a possible clue to fluctuations in the haddock catch this side of the Atlantic ? ${ }^{3}$

The peculiarity of the haddock is that it spends nearly all its life in comparatively deep water; 40 per cent. of the North Sea catch, for instance, is caught at 20 to 30 fathoms ; ${ }^{4}$ 20 per cent. at 10 to 20 fathoms (chiefly on the Dogger); 18 per cent. at 30 to 40 fathoms and 14 per cent. at 50 to 100 fathoms. But (unlike other species) the fry do not come inshore inside the 10 -fathom line. The older fish move about in shoals of haddock more or less of the same age and size. It is conjectured that there is a general southerly movement to the southward in summer, and a return to the northward

1 Fulton.

2 Heincke.

${ }^{3}$ See below, Hjort's observations on the universal shortage of haddock fry in 1902 and 1903.

${ }_{4}^{4}$ In 1913 English vessels landed 16,200 tons from the northern grounds of the North Sea, 9,000 tons from south of the Tees-Skaw line, and 8,200 tons from grounds which were not distinguished. 
in winter. Russell finds that from their second summer the fish move into shallow water in summer and out into deep water in winter.

This compilation is no doubt incomplete, but it indicates that the life-history of the haddock has not yet been described in English works on the Fisheries intended for non-expert consumption. There is room for serious and adequate research, which will be all the more difficult in that it is by no means always easy to determine the age of a North Sea haddock from its scales. A narrow zone sometimes appears in the scales during the summer months which makes scale reading very difficult.

\section{The Decline in the Catch}

Dr. Jenkins (The Sea Fisheries, p. 92) shows that between 1906 and 1913 there was a serious 'decline' not only in North Sea haddock but in the total yield of the haddock fishing. grounds accessible to English fishing-vessels. The decline was fairly steady, as the following table shows:

\section{Catch from all Grounds (All Tessels)}

Tons.

Tons.

\begin{tabular}{|c|c|c|c|c|c|c|c|c|}
\hline $1906^{1}$ & & & & 141,021 & 1910 & & & 101,973 \\
\hline 1907. & • & - & & 143,138 & 1911 & . & . & 105,714 \\
\hline 1908 & 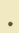 & 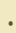 & & 126,614 & 1912 & . & . & 98,616 \\
\hline 1909 & . & . & • & 111,177 & 1913 & . & . & 77,693 \\
\hline
\end{tabular}

But the following detailed table indicates that, on all the haddock grounds, the catch can show perceptible recoveries in particular years.

As a fact the statistics, if reduced to a graph, do not show quite a continuous decline on any of the grounds ; and eight vears is a very short period on which to found definite conclusions. It is impossible to study the figures without realizing that 'good or bad spawning years' may have affected the catches at least as much as 'over-fishing'. Garstang, while carrying out his experiment in transplantation in 1905 , noticed an extraordinary abundance of small ${ }^{2}$ haddock and whiting on the Dogger Bank. There were so many, and they consumed the food of the young plaice to such an extent, that the latter grew much more slowly in 1905 than in 1904 or 1906 . Perhaps the heavy North Sea catches in 1906 and 1907 simply reflected that abundance? If so the 'decline' would probably appear less steep than it does at first sight, if the period of observation

1 In 1897 the eatch was 127,445 tons (Resources of the Sea, p. 269).

2 Pelonging to the 1904 brood which was so prolific in Norway. 
PLATE V

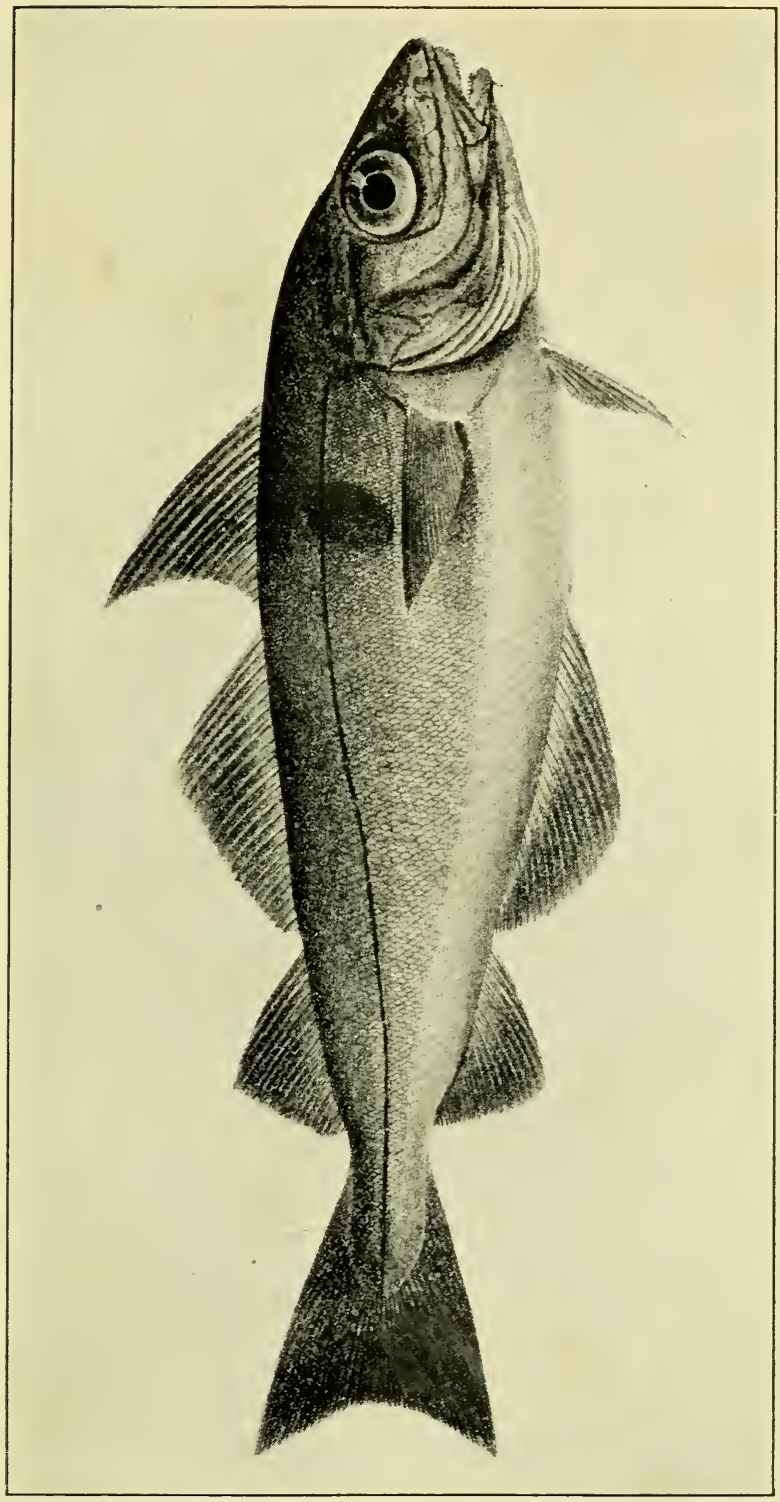

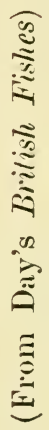

is

0

.

.

द

$=$ 

were extended over a longer series of seasons which might be more properly regarded as a ' cycle'.

\section{Fluctuations in Haddock Landings from the Main Steam Trawler Grounds}
I. North SeA.
II. ICELAND.
III. FaERoe.

IV. WEST OF Scotland.

1906

1907

1908

1909

1910

1911

1912

1913

\begin{tabular}{|c|c|c|c|}
\hline & $\begin{array}{c}\text { Daily } \\
\text { Average. }\end{array}$ & & $\begin{array}{c}\text { Daily } \\
\text { Average. }\end{array}$ \\
\hline Tons. & Cwt. & Tons. & Cwt. \\
\hline 101,744 & $7 \cdot 82$ & 20,712 & $11 \cdot 82$ \\
\hline 105,845 & $7 \cdot 82$ & 17,666 & $10 \cdot 41$ \\
\hline 87,352 & $6 \cdot 90$ & 18,799 & $11 \cdot 58$ \\
\hline 72,512 & $5 \cdot 84$ & 16,466 & $12 \cdot 06$ \\
\hline 64,634 & $4 \cdot 84$ & 17,942 & 11.98 \\
\hline 69,031 & $5 \cdot 28$ & 18,681 & $12 \cdot 28$ \\
\hline 64,637 & $4 \cdot 69$ & 15,506 & $9 \cdot 96$ \\
\hline 46,389 & $2 \cdot 99$ & 15,045 & $8 \cdot 12$ \\
\hline
\end{tabular}

$\begin{array}{ccc}\begin{array}{c}\text { Daily } \\ \text { Average. }\end{array} & & \begin{array}{c}\text { Daily } \\ \text { Average. } \\ \text { Cut. }\end{array} \\ \text { Cwt. } & \text { Tons. } & \text { Cut. } \\ 11 \cdot 08 & 2,029 & 3 \cdot 77 \\ 10 \cdot 19 & 3,227 & 3 \cdot 72 \\ 9 \cdot 48 & 7,205 & 5 \cdot 32 \\ 9 \cdot 29 & 7,736 & 4 \cdot 89 \\ 7 \cdot 51 & 4,688 & 3 \cdot 17 \\ 6 \cdot 55 & 3,959 & 2 \cdot 67 \\ 8 \cdot 00 & 3,514 & 3 \cdot 21 \\ 7 \cdot 05 & 2,638 & 2 \cdot 43\end{array}$

'Daily Averages' are the average catches per day and vessel.

\section{Notes on Table}

In the North Sea the largest catches, generally speaking, occur in July, August, September, November, and December. The percentage of small fish landed was always heavy, but has fallen from 51.09 in 1906 to 43.14 in 1913. The older haddocks appear to be near the coast from October to March, and away from the coast in spring and summer.

In Iceland April and May always produce the heaviest catches (as in the case of cod). The number of small haddocks landed is practically negligible.

In Faeroe the catch is at its height generally in July and August, but in some years the harvest begins in June and in others extends into October. Very few small haddock are landed.

West of Scotland. March or April (or both) are always good months, as are sometimes October and November. But the fluctuations are intense, and are obviously influenced greatly by causes other than the trawl. In 1908 and 1909, for instance, large catches were made in every month in the year. The small fish landed were 54.80 per cent. in 1906 and 63.16 per cent. in 1913.

\section{The Cause of the 'Decline'}

In 1913 the Board of Agriculture and Fisheries in its annual report (it had just published Mr. Russell's monumental report on his Market Measurements, 1909-11) noted this 'marked decline', and added 'the question of further investigations of this fish will have to be seriously considered'. In the same year the Fishery Board for Scotland, in discussing the figures, wrote that they were probably 'due to one of those fluctuations which are inseparable from the sea fisheries, and not to the impoverishment of the stock. This view is based on the fact that similar periods of depression have occurred before, as, for example, between 1895 and 1903'. In 1895, apparently, 
the catch was over 50,000 tons; in 1898 less than 37,500 ; in 1903 again over 50,000. Obviously no one knew what caused the fluctuations, and apparently no very serious attempt has been made to discover the cause.

Certain causes which have been assigned to similar fluctuations in the case of other fish can be ruled out.

1. They were not due to the destruction of the fry by men fishing on the shallows, ${ }^{\circ}$ because the haddock ${ }^{1}$ fry do not frequent the shallows and are not destroyed by men at all.

2. They could apparently not be proved to be due to the fact that trawlers were destroying immature fish, for small haddock after 1906 formed a smaller and smaller proportion of the North Sea landings. The actual figures (which take no account of the large numbers of small haddock thrown overboard) were :

\section{Small Fish (Percentage of Catch) ${ }^{2}$}

1906. 1907. 1908. 1909. 1910. 1911. 1912. 1913.

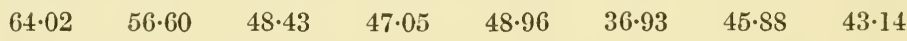

This is no place to suggest possible explanations. It is enough to note that in 1919 a fleet, which was by no means back to pre-war strength, caught a great many more haddock than the 1913 fleet.

The catches compare as follows :

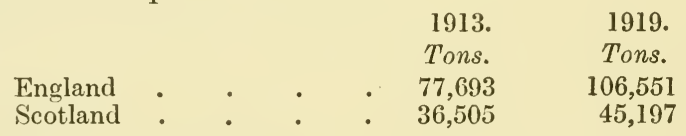

The problem may therefore now be shortly stated :

1. What caused the diminishing returns of the haddock fishery between 1906 and 1913 ?

2. What caused the recovery in 1919 ?

To ascribe the phenomena to 'natural fluctuations' is obviously to beg the question. We want to know what eaused

${ }^{1}$ Comparatively few of the Dogger Bank haddock in 1913 were classified as 'small', only 36 per cent. in fact. The grounds beyond the 20 -fathom line produced many more small haddock than the shallows; and the $\mathrm{F}$ areas (between 50 and 100 fathoms) produced as much as 60 per cent.

${ }^{2}$ The percentage of small haddock from the chief North Sea grounds was in 1913 :

\begin{tabular}{|c|c|c|c|c|c|}
\hline Dogger & & & & $\begin{array}{c}\text { Fathoms. } \\
10-20\end{array}$ & $\begin{array}{c}\text { Per cent } \\
36\end{array}$ \\
\hline East of & Dogger & & & . $20-30$ & 37 \\
\hline D area & . & • & • & . $30-40$ & 42 \\
\hline E, & . & . & . & . $40-50$ & 54 \\
\hline Fi & . & . & . & . $50-100$ & 61 \\
\hline
\end{tabular}


the fluctuations. It is unnecessary to point out that the answers may throw some light on the plaice problem and other alleged cases of 'overfishing'.

There is at present little indication that British investigators intend to tackle this question seriously. But the Norwegians have for years been, and still are, collecting data bearing on the life-history of the fish.

It is greatly to be hoped that this Norwegian work will be explained step by step to British owners and British skippers, who are the haddock fishers of the world par excellence.

Few naturalists have a gift of explaining fishery problems in simple language equal to that of the great sea-going naturalist Dr. Hjort, who has spent his life in close intimacy with deep-sea fishermen in all waters. Most unfortunately his haddock work has not been brought up to date in English. A separate chapter will explain its earlier stages.

\section{Future Investigations}

Further information is required as to the spawning grounds of the haddock, the food of the larvae in the earliest stages, the supply of that food (both animal and regetable) in the waters in which the larval period is spent, and the growth on all the grounds which our fleets visit. It is true that Dr. Hjort's deductions are based on data collected from the whole of the North Sea. It is also true that the work can be entrusted to the Norwegians with perfect confidence that it will be well carried out. But the fish are of such great interest to Britonsboth producers and consumers-that British naturalists ought to be in close touch with all haddock investigations; and even if this is a matter which cannot immediately be arranged, all researches into the species should be explained, not only when they are 'complete', but step by step as they proceed. 


\section{CHAPTER XVI}

\section{NORWEGIAN INVESTIGATIONS ON THE HADDOCK}

ON pp. 27-34 of his paper ' Some Results of the International Ocean Researches', published in English by the Scottish Oceanographical Laboratory, Edinburgh, in 1908, Dr. Hjort discusses the earlier Norwegian investigations into the haddock. It is interesting to note that this paper is not even mentioned by Jenkins in his Sea Fisheries (1920) : indeed, he says nothing of the haddock work of the Norwegians. The latter found that newly-hatched haddock drift, especially in July, right out of the North Sea in myriads. Some are driven towards the Norwegian coast, some into the Skagerrak, and some north into the 'Northern Sea' between Iceland and Norway. By 1907, Dr. Hjort stated, enough material had been collected in Norway 'to put us in possession of the whole life-history of the haddock '.

Trawling experiments at Aalesund, on the west coast of Norway, in 1906, combined with scale reading (which is, Dr. Hjort says, quite easy, though an English investigator has found some difficulty in reading the North Sea scales after the third and fourth year), give the rate of growth as follows:

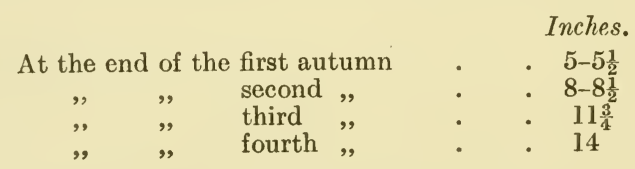

With the young fish were caught older haddock running as large as 30 inches. It was established that in Norway fishermen systematically fished for and caught haddock from two to eleven years old ; that these fish grew about 4 inches a year for the first year or so on the average; that growth was irregular; and that fish spawned in one year would on the whole grow much less quickly than those spawned in another. As the fish approached eleven years in age the annual growth became smaller and smaller. The largest fish examined were some haddock from the Barents Sea landed at Hull. They were 18 to 30 inches long and from nine to fourteen years old. Their scales showed "very slight growth and a poor structure-the characteristics of old age'.

The Norwegians examined a mass of haddock material from 
the Skagerrak and the North Sea. They had before them, not only the statistics of the catches of regular trawlers, but also the haddock caught during six hundred experiments by research steamers with trawls of the same dimensions. All the material collected was placed at the disposition of English and German scientists.

The Michael Sars also collected haddock from every part of the North Sea.

The examination of this wealth of material led to the following discoveries :

1. Dogger Bank haddock will run larger than haddock caught in the same month on the deeper banks in the northern portion of the North Sea.

2. In the year 1904, both in the North Sea and in the Skagerrak, the 'small' haddock (i. e. those hatched in 1902 and 1903) were very scarce indeed; in 1906 large numbers of two-year-old haddock ${ }^{1}$ born in 1904 were caught. In other words, very few fish were hatched in 1902 and 1903, and when they were two years old they were much smaller than fish of the same age caught in 1906. These facts seem to tally with the shortage of eggs collected by the American spawn-takers in certain years ( $v$. supra, p. 79).

3. The six hundred experiments all over the North Sea and the Norwegians' own experiments alike showed that there was 'a preponderating quantity of younger fish of $1 \frac{1}{2}$ to $2 \frac{1}{2}$ years old' (8 to 12 inches), and that fish older than this were much less abundant. In most waters only one or two broods of mature haddock are found.

Hjort is convinced, and every trawler owner will be convinced with him, that these experiments give a much truer picture of the state of the haddock stock than do statistics of landings. As Hjort says, fishermen lay themselves out to catch big fish ; they make for the grounds where they know the fish run large, and, he might have added, they throw away a very large number of small haddock. So the English statistics of small haddock landed mean really very little in the eyes of any one who has studied the trawl-fishing at sea. If haddock spawn for the first time in their third and fourth year, it is reasonable to conclude that regular trawlers haul up on deck more immature than mature haddock. Whether these young fish come to market or go overboard (usually dead) depends whether the skipper knows that there is a demand for small fish, and whether he thinks he can fill up with bigger ones.

1 Garstang had found them the year before (1905) on the Dogger. See Chapter XV, p. 80. 
Both Dr. Hjort and the Danish biologist, Dr. C. G. J. Petersen, were convinced in 1907 that ' in all proposals for preserving the fish supply attention must be directed towards the protection of the older rather than the younger year classes'. They argued that whether protected or no there will always be a large number of young fish hatched out. Their conclusions seemed to approximate to those of Garstang with regard to the plaice when he argued that it is useless to look after the small adult fish. It seems probable that they were right. The main problem is to produce the greatest number of haddock of an age when they will fetch the best price. It is towards the solution of this problem probably that science should address itself. For the plaice Garstang's solution is transplantation. For the haddock, so far as the writer is aware, no solution has been suggested. Meanwhile Dr. Hjort and his colleagues have gone far towards explaining the pre-war shortage-such as it was.

They have shown in the course of their scale reading that 1904 and 1912 were years which produced an extraordinary abundance of haddock fry-just as they did of herrings and of cod. And they have shown good grounds for believing this abundance to be due to an unusual wealth of minute vegetable food in the sea at the exact moment when the baby haddock first began to feed. This theory is discussed in full on pp. 94-6 below in connexion with cod. It is here enough to point out that the abundant hatch in 1904 may account for the increased catch $^{1}$ in the North Sea in 1907, while that of 1912 , which was protected further by the minefields for four years, may explain the great numbers now being caught on all the grounds. Until it can be shown that the present abundance is not due to abnormally small infant mortality in certain years on the spawning grounds, it would be rash in the extreme to ascribe it (solely at any rate) to the "closure' during the war.

See p. 81 . 


\section{CHAPTER XVII}

\section{THF COD}

\section{The European Catch (Analysed)}

The comparative catch in 1913 was as follows :

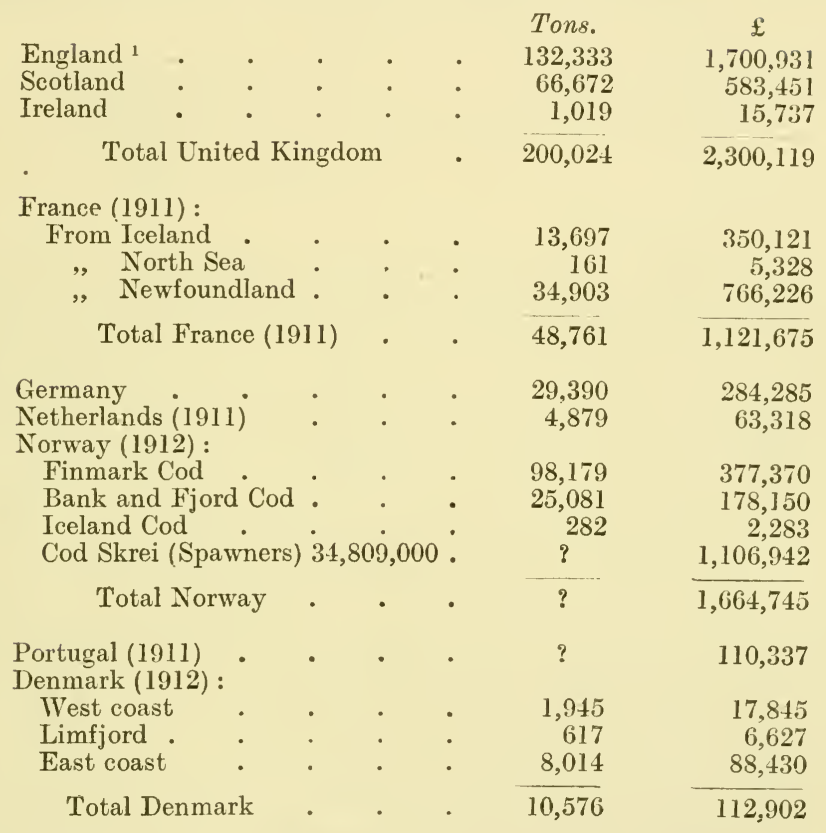

The British are therefore the chief cod-fishers in Europe ; but they are not so far ahead of other nations as in the case of plaice and haddock.

${ }^{1}$ In 1920 the landings were :

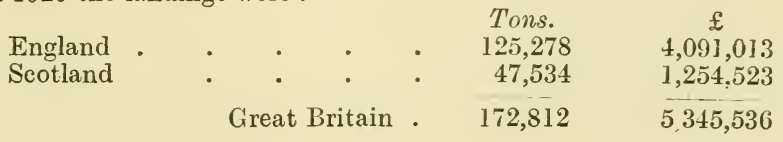




\section{Analysis of the British Catch}

The following ports landed over 1,000 tons of cod:

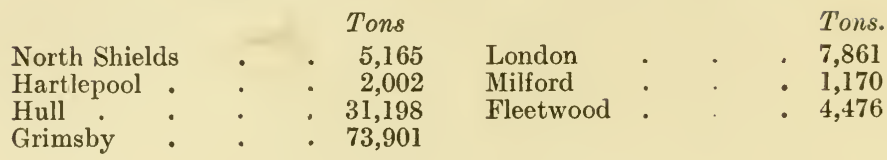

Total 7 ports : 119,373 tons.

Other steam-trawler ports landed as follows :

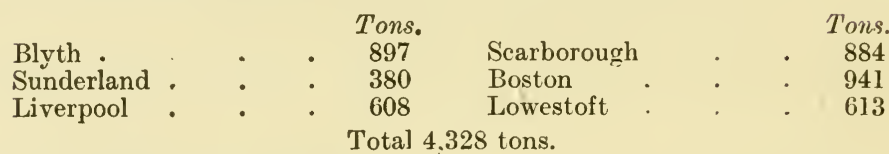

All other ports gave 9,635 tons

In Scotland steam trawlers landed . $\quad$. 47,652

Out of 66,672 tons landed.

$$
\text { liners }, \quad \cdot \frac{2,839}{50,491}
$$

The main British cod-fishery therefore depended on steamers, and the fish landed in England came from the following banks,

\begin{tabular}{|c|c|c|c|c|c|}
\hline Iceland & . & & . & $\begin{array}{l}\text { Tons. } \\
53.266\end{array}$ & $\begin{array}{c}\text { Per cent. of Catch. } \\
41.29\end{array}$ \\
\hline North Sea & • & - & . & 43,386 & 33.63 \\
\hline Faeroe & & . & . & 17,393 & $13 \cdot 83$ \\
\hline West of Sc & otland & . & . & 8,046 & $6 \cdot 24$ \\
\hline
\end{tabular}
chiefly :

\section{Distribution of Cod in the North Sea, 1913}

English vessels, so far as their grounds have been distin. guished, in 1913 caught 21,671 tons of cod to the southward, and 15,891 tons north of the Tees-Skaw line in the North Sea. The area south-east, east, and north-east of the Dogger, from the Skagerrak southwards and westwards through the "east mud' to the Outer Silver Pits between the 20 and 30 -fathom lines, is the most prolific-as it is the largest and the most heavily fished (9,700 tons). Then comes the Dogger with 5,000 tons and the B 2 area (also between 10 and 20 fathoms) between the Dogger and the English coast, which produces about 4,000 tons of cod-mostly small cod.

In the northern waters nearly 7,000 tons-which were mostly large cod-were caught in the D 1 area-the 10,000 square miles between the 30 and 40 -fathom lines from the Long Forties southwards; 3,000 tons in the central deeps between 40 and 
50 fathoms; and 2,900 tons (still mostly large cod) between 20 and 30 fathoms mostly off the Firth of Forth (C 1). The actual figures are:

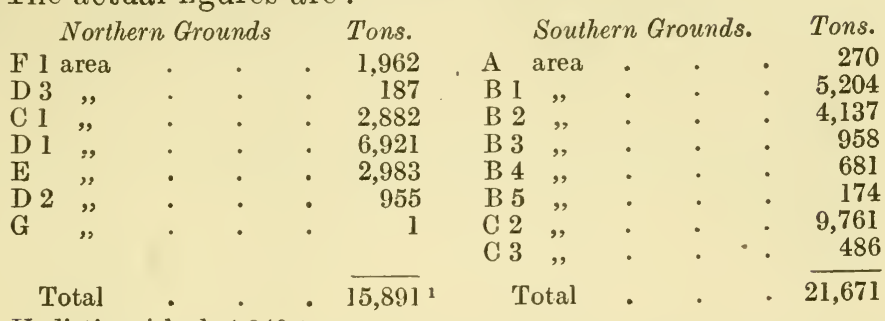

Undistinguished, 4,840 tons.

The distribution of the catch among vessels was as follows:

Tons.

Steam trawlers caught. . . . 124,477

Steam liners $\quad . \quad 0^{-} \quad . \quad 4,425$

Sailing trawlers $: \quad . \quad \therefore \quad . \quad 854$

Sailing liners $\quad \cdot \quad \cdot \quad \cdot \quad \cdot \quad 515$

Inshore fishermen $\quad$. $\quad$ - 2,062

132,333

\section{Life-History}

In the hatchery at Woodshole, U.S.A., 9,168 fish were penned in three years, and allowed to spawn naturally. They gave $815,000,000$ eggs - an average of 111,000 per female, if it is assumed that there was one male to every four females. ${ }^{2}$ Very large ' hens' are, of course, not used for breeding purposes in the hatcheries-and large hens will no doubt produce more eggs, though the eggs and milt of old fish are not so good as those of younger ones. But the 'good and bad hatching years' are well marked, and the yield varies greatly from year to year. 97 per cent. of the eggs taken in hatcheries are impregnated. The Americans believe that there is a heavy loss in nature through failure of impregnation. Unfertilized eggs are seldom found at sea, but experiment in America has shown that they sink after floating from eighteen to thirty-six hours at most. The fertilized eggs float-at the surface-if the density of the water is sufficient, and hatch out according to the table below. The eggs"are about one-eighteenth of an inch ${ }^{3}$ in diameter on the average. That is to say, about 406,000 of them are contained in a fluid quart. ${ }^{4}$

1 These figures omit the large catch by Scottish ressels in these waters.

${ }^{2}$ But it is probable from hatchery experience that not more than one-third of these hens actually yielded good eggs, in which case the number would be about 330,000 per fish. $3 \cdot 055$ inches or $1.386 \mathrm{~mm}$.

4 This and similar statements with regard to the number of eggs contained in a quart are based on the table of H. von Bayer, Bull. U.S.B.F. xxviii, p. 1013 ; see below, Appendix III, p. 206. 
Americans have worked out the following incubation table for cod (cf. Manual of Fish Culture, p. 206):

$\begin{array}{cc}\text { Mean Water } & \begin{array}{c}\text { No. of Days } \\ \text { Temperature. }\end{array} \\ \text { before Hatching. }\end{array}$

$\begin{array}{cc}\text { Mean Water } & \text { No. of Days } \\ \text { Temperature. } & \text { before Hatching. } \\ 40^{\circ} \mathrm{F} . & 17 \\ 41^{\circ} \mathrm{F} . & 16 \\ 42^{\circ} \mathrm{F} . & 15 \\ 43^{\circ} \mathrm{F} . & 14 \\ 44^{\circ} \mathrm{F} . & 13 \\ 45^{\circ} \mathrm{F} . & 12 \\ 46^{\circ} \mathrm{F} . & 11 \\ 47^{\circ} \mathrm{F} . & 10 \text { or } 11\end{array}$

They have found that thousands of eggs are, during this period, washed ashore, and Sars noticed the same phenomenon in Norway. It was found also that when the water temperature falls below $38^{\circ} \mathrm{F}$. the period of incubation is so long that the fry are weak when they appear, and it is then very hard to hatch out more than 25 to 50 per cent. of the eggs successfully. Whether low temperature reduces the vitality of cod larvae floating in the sea the writer does not know. ${ }^{1}$ But Hjort has noticed that in 1901 and 1902 and 1903, when the Arctic icefield came far south off Norway, all fisheries suffered.

The spawning season is from February to May, and the spawning takes place generally in shallower water than that of the haddock or coalfish, at 10 to 40 fathoms. Off Norway, however, it is at 40 to 50 fathoms. The fry are carried into the coastal shallows all round the North Sea, from the shore to the 40-fathom line, the Skagerrak, the Faeroe Banks, the Norse fjords, the north and east coast of Iceland, and in the Arctic Ocean.

All round the North Sea the fry come inshore from $\frac{3}{4}$ inch to 4 inches long in May, June, July, and August. In Norway the eggs were always just over the spawning banks-and nowhere else-in March and April, but by June the small fry have scattered far away and outside of them, and in August and September fry several inches long, which had apparently come either from Romsdal Bank or from the Lofotens in the Norse Sea, were found floating over great depths one hundred miles north of the nearest land. The fry go gradually to the bottom (wherever they may be drifting at the time) soon after their mouths begin to function. ${ }^{2}$ Small one-year-old cod have been caught at 40 fathoms in the Skagerrak, and at 150 fathoms in the Arctic Ocean. In Iceland-our main fishing-ground-

1 See also Hjort's Canadian investigations. Below, p. 97.

2 In eaptivity fry take to mid-water at the end of their first week and then go to the bottom. 
the cod have been systematically studied by Dr. J. Schmidt. ${ }^{1}$ They spawn during the winter in the warmer water on the south and south-east coasts ; the current carries the eggs right

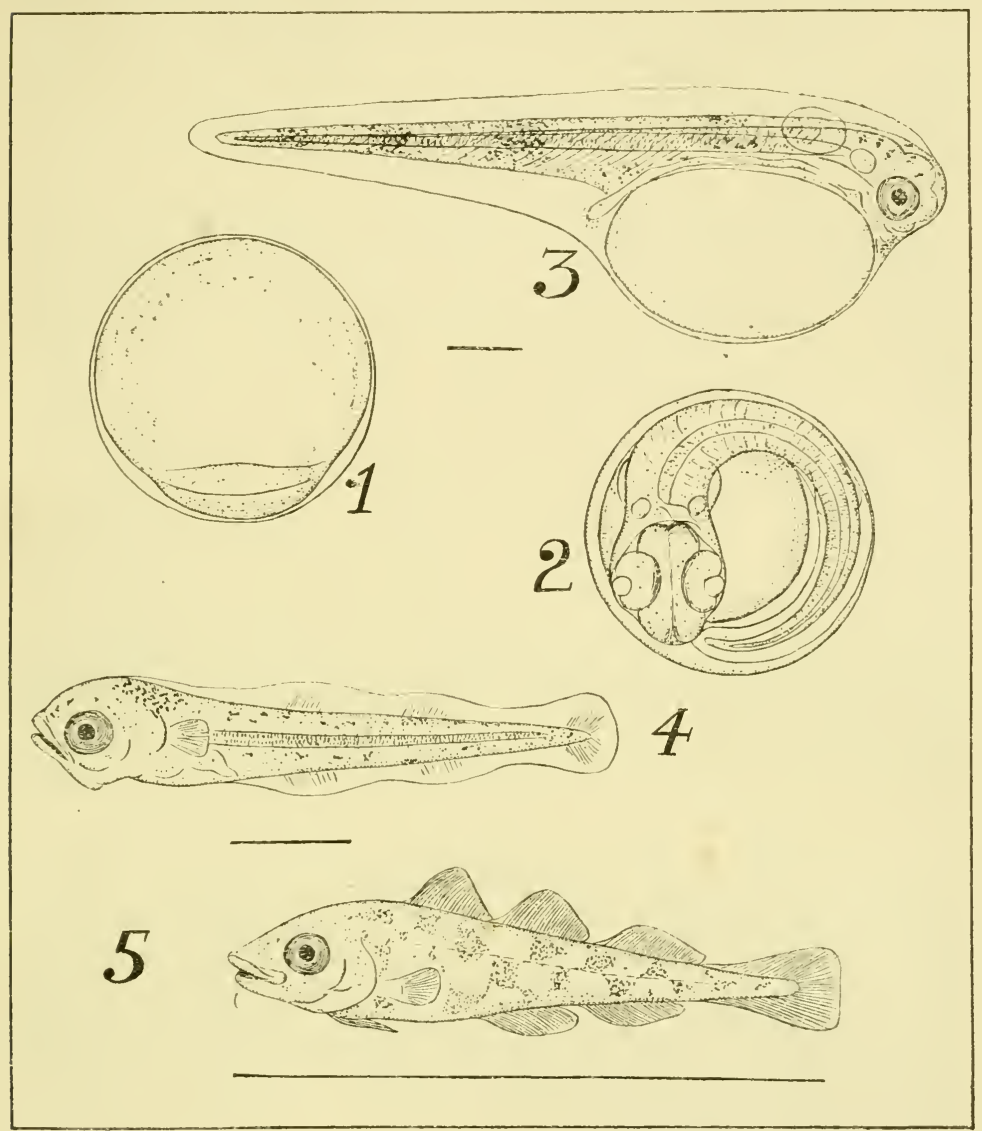

[Draun by Dr. James Johnstone.

Fig. 6. DEVELOPMENT OF THE COD

1 The unfertilized egg. 2. The egg a few days before hatching. 3. Larva, $0 \cdot 2$ inch long. 4 . Larva, $0 \cdot 4$ inch long. 5. Young cod, $2 \cdot 3$ inches long.

up the west coast, and by August the fry are distributed at the bottom along the north of Iceland-where the large cod are caught in the summer. By the following April they are 2 to $3 \frac{1}{2}$ inches long, and are as far east as the Eskifjord on the east coast (see map, p. 101).

Working in the S.S. Thor. 


\section{Rate of Growth}

The rate of growth varies greatly. In the south of the North Sea they reach as much as 8 inches in their first year; along the Norwegian coast they are on the average about 3 inches at the same age, and half that size in the Skagerrak. The food in these stages consists of young shrimps and other minute crustacea.

\section{Scale Reading}

Apparently the North Sea cod-scales are not so easy to read as those of the Norway coast. The winter rings are less clearly marked because the check in the growth of the fish is less severe. For the Norse fish, Hjort in 1914 gave a complete scale of average growth as follows :

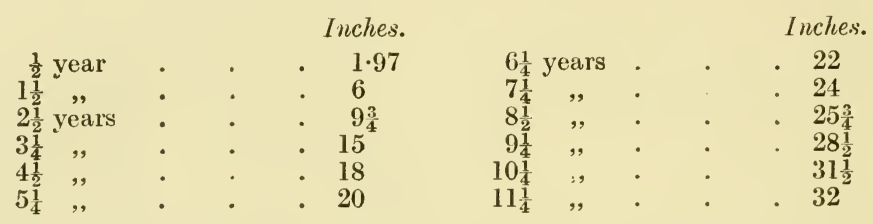

Obviously the rate will be a good deal quicker in the south of the North Sea on the average. Hjort notes that in the second and third years cod continue to grow rapidly, and that from the fifth year the winter rings become better marked.

\section{Maturity}

Maturity is reached occasionally in the second year, but not as a rule till the fourth. Here again the variations are marked. The North Sea spawners are seldom less than about 30 inches long. In the Lofoten Islands the smallest spawners in 1907 were $27 \frac{1}{2}$ inches long and six or seven years old ; the largest 46 inches and sixteen or seventeen years old. In the Danish Belt fish are mature at 12 inches.

\section{Migrations}

The movements of the large cod round Iceland have been noticed. Statistics of catch and marking experiments show that the large cod congregate on the southern shallows of the North Sea in winter, and leave in the summer for the deeper waters towards the north; they are caught off Finmark in the summer, and on the Norwegian Spawning Banks in the winter.

Towards the end of summer, on our east coast, the longshoremen often begin to catch codling of half a pound to a pound; 
a fortnight later they will be getting two-pounders, and by Christmas large cod will be feeding within one hundred yards of the shore. But the fluctuations from year to year on all grounds are extreme.

\section{Fluctuations in the Catch}

The following table of the comparative catch by English steam-trawlers on the main cod-banks for the years 1906 to 1913 seems to show that the efforts of mankind have (hitherto at any rate) produced no traceable effect upon the supply of cod. Fluctuations, it is true, occur-and very great fluctuations-on all the banks. But these are, as we shall see, almost certainly due ultimately to the play of natural forces such as the advance or contraction of the polar sea-ice over particular periods. This is true not only of cod, but of other fish like the herring and the coalfish. It does not mean that ocean research can be of no use to cod fishermen. It means just this : that research should be directed towards the study of the effect of these cosmic pulsa. tions on the birth, growth, and wanderings of the fish. As this is ascertained-and it is surely ascertainable-it will eventually be possible for Science to foretell when and where the fisherman stands the best chance of finding the particular sort of cod which the markets demand; and inquiries which at first sight appear to be remote from the practice of fishery will be found to be of real economic value.

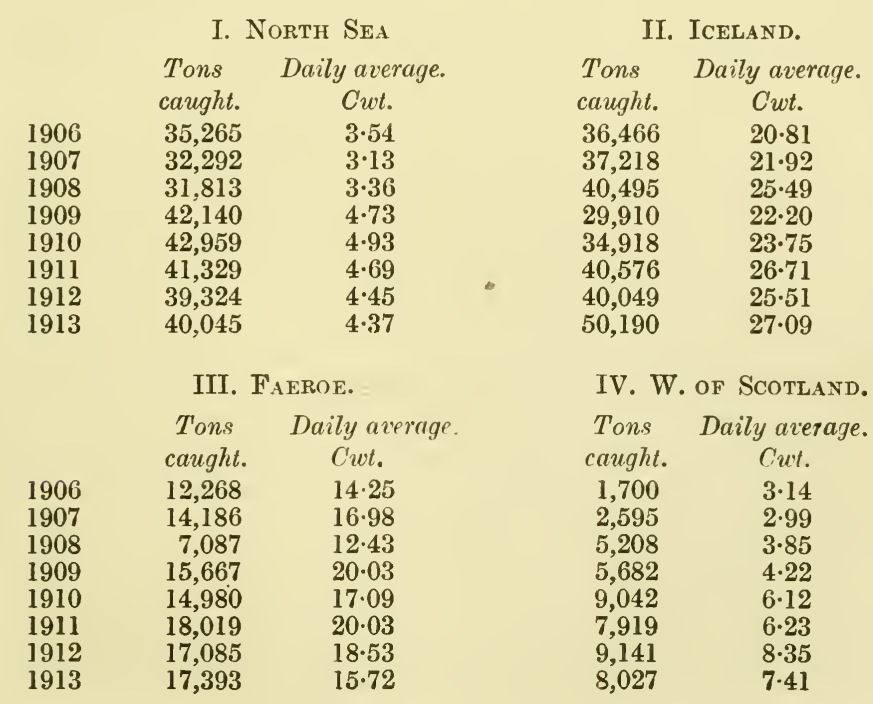




\section{Notes on the Table.}

I. In the North Sea the heaviest catches of large cod generally occur in March. They apparently congregate chiefly from January to May. But in some years, for instance in 1908, 1909, and 1910, they are also abundant in August, September, and October. The total catch does not vary very heavily from month to month. But generally the lightest catch is in May.

II. In Iceland the catches of large cod are usually in April and May. And the heaviest total catch is always in March, April, and May. The leanest months are July to November inclusive.

III. In the Faeroes the large cod predominated as follows. 1906 in March and April ; 1907 in March, April, June, and July ; in 1908 in January, September, and October (but this was a bad year) ; in 1909 in August and September ; in 1910 in February. The largest total catch occurs as a rule in July and August. But the catches are sometimes heavy also in January, February, March, June, September, and December.

IV. To the 'Westward of Scotland', an area of 32,100 square miles which is the meeting-place of the 'Northern' and 'Southern' fishes, the large cod predominate in every month in the year. Generally speaking the heaviest catches appear to be made in March and April, but the fluctuations are almost incredible, and it is impossible from the statistics to say what constitutes the cod season in these waters.

It will be seen that the international investigators have done a great deal of work on the cod. They are agreed that the species is in no danger of diminution. Most of the work has been done by Danish, Norwegian, French, and German investigators, though the Scottish research vessel Goldseeker has also made important observations. But the work is at present mainly in the very competent hands of Norway. As in the case of other species, it is clearly desirable that arrangements should be made to explain the progress of the work in simple language to British owners and skippers as it goes on-just as Dr. Hjort is wont to explain it to Norwegian fishermen.

\section{Dr. Hiort on the Newfoundland Cod}

In 1910 the Michael Sars investigated the Newfoundland Banks. At the end of June she found the cod to the south of the Great Bank just ready to spawn at about 35 fathoms. At that time the temperatures were (a little north of $50^{\circ} \mathrm{N}$.) down to the 20 -fathom layer $42.8^{\circ} \mathrm{F}$. and over. At the bottom, however, the water went down to between $35^{\circ} \mathrm{F}$. and $39^{\circ} \mathrm{F}$., and on either side of the bank the temperatures below 20 fathoms were very nearly what Nansen found at the North Pole. These big cod, 24 to 40 inches long, therefore begin spawning in July; whereas the smaller race of cod on the New England coast begin in November and finish in April.

\section{Dr. Hjort on the Fluctuations in the Stock of Cod}

In the year 1908 the Norwegians who were studying codscales discovered an enormous preponderance of the fish hatched 
in 1904 in the catches, and subsequent investigations have confirmed their conclusions that 1904 was an extraordinarily ' good cod year', just as it was a good herring year, and a good haddock year. In 1913, moreover, Dr. Hjort noticed an unusually large number of one-year-old baby cod along the northern coast of Norway; and scale reading now shows that the 1912 brood-again as in the case of herrings and haddockwas especially numerous. What could be the reason? The first thing was to discover whether the spawners in 1904 had deposited an unusually large number of eggs. This could be tested, for in the Lofoten Islands every year cluring the spawning season large quantities of cod roe are salted. It is, of course, possible that the demand for this commodity is fixed at a certain limit which it would not be profitable to exceed. Or possibly barrels are not available to cope with a sudden expansion of the cure. Otherwise it would be natural to expect to find that in 1904 an unusual amount of roe was salted. As a matter of fact the statistics of the trade do not show that the "pack' of cod-roe fluctuates at all in sympathy with the fluctuations in the numbers of cod fry. And Dr. Hjort has concluded that there is no evidence that an unusual amount of spawn was produced in 1904 or in 1912. So one possible explanation was eliminated.

Both Sars and the Americans had noticed that storms of wind from particular directions cast great numbers of cocl-eggs ashore. Perhaps 1904 was unusually free from such storms? Could that be the explanation? The Norwegians think not. The number of eggs thus destroyed are, they think, negligible in comparison with the enormous numbers produced. Moreover, the Norwegian herrings, whose eggs are fixed to the bottom at 40 to 100 fathoms, could obviously not be affected in this manner. Their fry were, like the cod, unusually numerous in 1904, and it was reasonable to suppose that like effects were due to like causes. The small fry were not overcrowded. There was plenty of room for them all. For they were well fed and in perfect condition.

The problem then resolved itself into discovering some particularly favourable circumstance which had reduced the mortality either among the eggs or the larvae. While Damas and Hjort were towing their plankton nets over the Lofoten spawning grounds in February or March, they found that as a rule their catches consisted entirely of cod-eggs, with a few of the copepods (Calanus finmarchicus) which the Finner whales eat so largely. But sometimes in April, the tow-nets were suddenly filled with a brown mass. This on examination 
proved to consist of the floating spores of vegetable diatoms, which form the food of copepods and of some species of fish larvae, in such numbers that it looked almost as though they had been projected over the surface by an explosion. The appearance of these diatoms is not at all constant. It must, as it seems to the writer, resemble the formation of diatomic 'scum' on chalk stream springs on sunny days in Great Britain-that bete noire of trout breeders. It is obvious that cod eggs may hatch out, and the mouths of the larvae may begin to function at a time when there are few or none of these diatoms or of the small animals which consume diatoms at the surface within their reach. If that is the case they will be thrown back entirely on the contents of their yolk-sacs for their 'baby food '. They will be 'weaned too suddenly', and a large proportion will die-just as we have seen turbot may die-from the effect of a sudden change of diet. And on the whole the odds are heavy that this is what will happen in a normal year. On the other hand, there is a chance that the larvae may begin to make their first feeble attempts at feeding just as the mass of little plants comes to the surface in their midst. They will then, like the turbots in Anthony's glass barrels, find the exact food which is necessary to eke out the supply in their yolk-sacs. and an unusually large proportion will survive the "critical period ', which, in the case of most fish, is probably the period when the sac is just or nearly absorbed.

Dr. Hjort believes (and every one who has reared thousands of young trout through this ' critical period', and lost tens of thousands before he learnt the secret, will find it easy to accept the belief) that in 1904 and in 1912 this is just what happened. In both years a big ' rise' of diatoms happened to occur just as the young cod first began to take food. The result was that an abnormally small proportion was wiped out of existence. Now if Hjort's hypothesis is correct it will be seen at once that we are within reasonable distance of being able to forecast the Norwegian cod harvest in any particular water many years ahead.

So far as cod are concerned-and herrings and haddock alsoa series of laboratory experiments on the lines of Dr. Anthony's ${ }^{1}$ experiments with turbot and with the same apparatus might settle the question once and for all. Are any such experiments contemplated in this country? None have been announced. But we may rest assured that they will be made in Norway.

It is, however, lamentable-almost tragic-that this great work of Dr. Hjort and Dr. Damas should have for years remained

${ }^{1}$ See p. 67. 


\section{PLA T E V I}
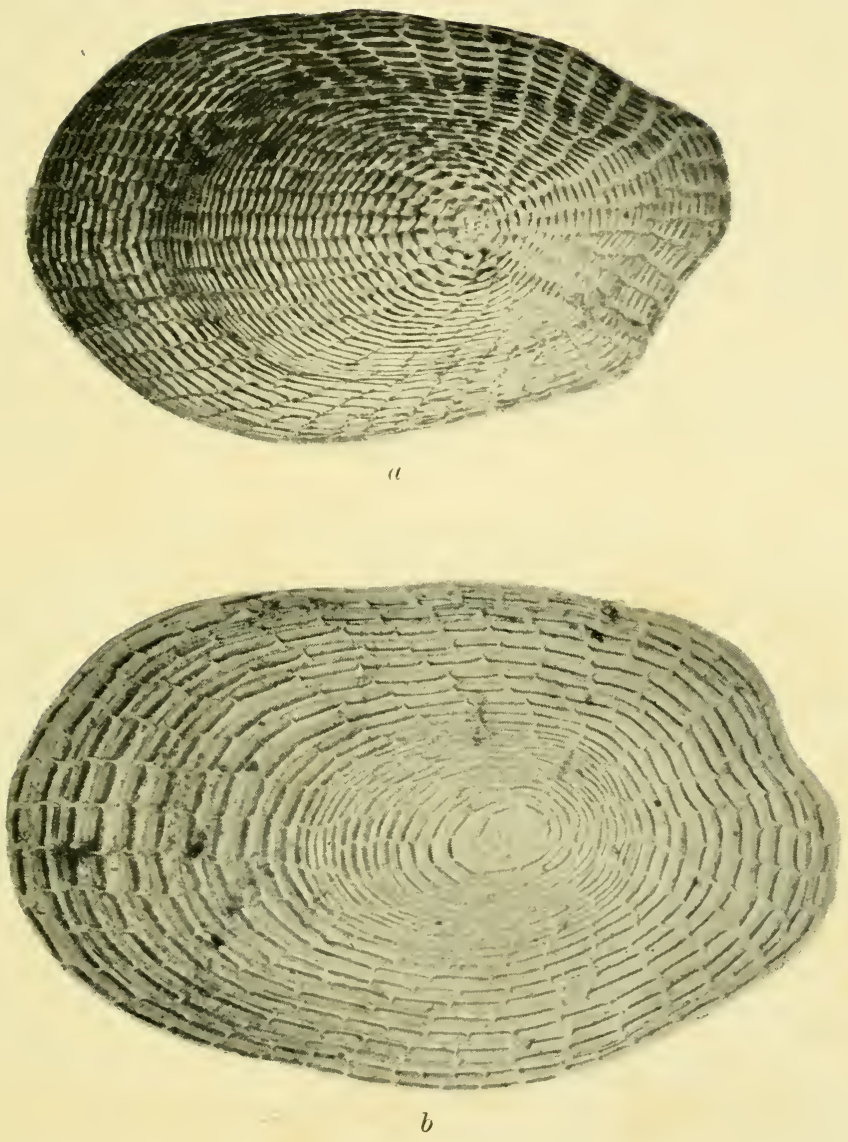

SCALES OF COD (Meek)

a. Cod $5 \frac{3}{5}$ in. (first summer).

b. Corl $9 \frac{7}{10}$ in. (second summer). 

undiscovered to the large numbers of men who make their livelihood chiefly out of haddocks and cod and herrings in this country, and there is little doubt that, if Science could find time to explain, they would eagerly help to find the money to further experiments like these.

It will be noted that Dr. Hjort first noticed unusually large numbers of one-year cod-fry which had been spawned in 1912 swimming in the Norwegian seas in 1913; and that the codscale rings in subsequent years showed that his observations were correct. This is a somewhat important coincidence, for there are sceptics who still disbelieve that the age rings on the scales indicate the age of the fish correctly. What will interest the fishermen is that Dr. Hjort was actually in a position in 1913 to say that there would probably be good catches of cod in Norwegian waters four or five years later.

It needs no argument to show that investigations into the life-history of the microscopic plants and animals upon which the young cod feeds are a vital part of the inquiry into that of the cod itself.

\section{Dr. Hjort on Canadian Cod Fisheries}

In 1914 Dr. Hjort visited Canada, and the Canadian Government has just issued his very interesting report on his investiga. tions into Canadian fisheries. Unfortunately he was given a steamer for thirty days only. One of his most interesting discoveries was that there was a particularly rich out-turn of cod-fry in Canadian waters in 1904, just as there was on this side of the Atlantic. Cod were spawning in the Gulf of St. Laurence, but he found no eggs floating in the sea. The cod were spawning in a temperature of $29 \cdot 3^{\circ} \mathrm{F}$. At first Dr. Hjort thought that all the eggs would be killed by the cold; but he had experiments made in Copenhagen, and found that the eggs would develop below freezing-point. He then decided that
all the eggs were probably drifted out to sea by the very strong
current which sets current which sets out of the Gulf to the eastward (?).

Had Dr. Hjort been familiar with the work at Woodshole Hatchery he would have known that eggs are frequently hatched out there in water at $35^{\circ} \mathrm{F}$., but that, if it is as cold as this, the fry are invarjably weak. Now even at $31^{\circ} \mathrm{F}$. the eggs take fifty days to hatch out; at $29^{\circ}$ or $30^{\circ} \mathrm{F}$., therefore, it can be assumed that they would float for over two months-unless the density of the water were insufficient to keep them at the surface. How far would they drift before they reached a temperature of $38^{\circ} \mathrm{F}$., which is the lowest temperature at which healthy fry may be expected? And would this long drift during 
incubation in any case weaken the larvae when they hatched out? It is to be hoped that the Canadian Government will follow the eggs downstream and find out answers to these questions. But a cruise of thirty days will obviously be very much too short for the purpose!

It may seem that this inquiry could be of no practical interest to fishermen on this side of the Atlantic, for, off the Norwegian coast, the eggs would have to drift very far North in a normal year before they reached water as cold as $41^{\circ} \mathrm{F}$. ; and even at that temperature they would hatch out in sixteen days. ${ }^{1}$ But it remains to be seen whether in abnormal years the freezing of the sea farther south than the normal southerly limit of the sea ice might not produce disastrous results on baby cod, and in this direction the Canadian inquiries might be of incalculable benefit.

1 Depths of Ocean, p. 227. 


\section{CHAPTER XVIII}

\section{THE COALFISH OR SAITHE}

\section{The European Catch (Analysed)}

The comparative eatch in 1913 was as follows:

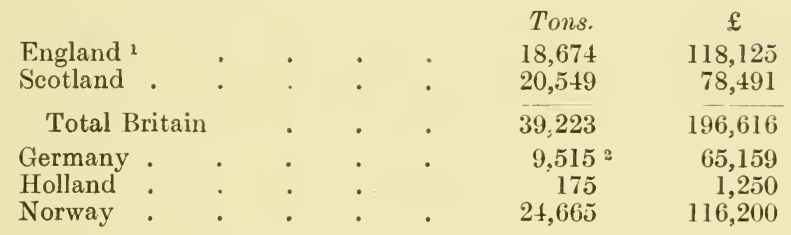

The importance of the fish lies in the fact that it is "poor man's food'. In point of bulk it is the third of our British staple bottom fishes, and in Norway it ranks only below the cod. It is extremely cheap, and as late as 1909 and 1910 it was customary to throw away the coalfish caught on the north-west coast of Ireland, and to retain their livers only.

\section{The British Catch}

The following English ports landed 1,000 tons and over:

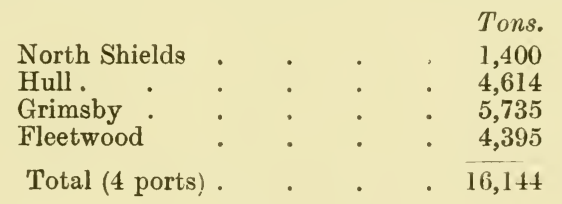

Tons.

In Scotland the steam trawler catch was . . 16,728 and the steam liner catch was . . . . 1,244

Total . . . . . . . 17,972 out of 20,549 .

The coalfish is therefore mainly a steam trawler fish.

In 1920 the landings were :

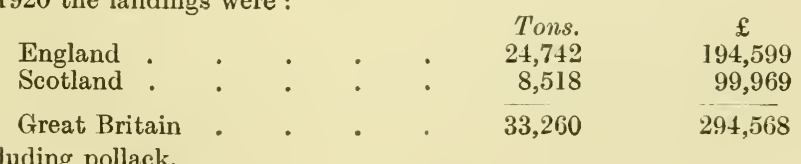

2 Including pollack. 
The Main Coalfish Grounds were, according to English statistics :

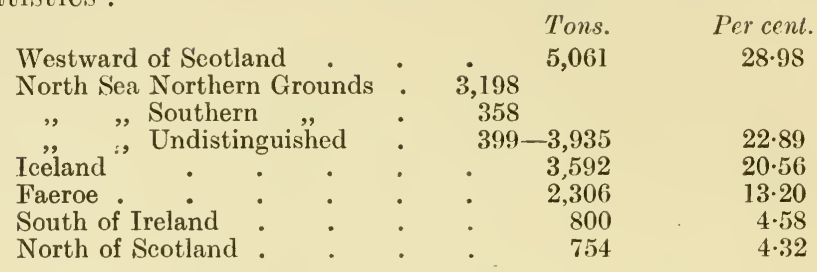

But it is only to the northward and westward of Seotland that it forms a really important part of the catch. Very few coalfish are caught at less than 30 fathoms, and most of them came from 40 to 100 fathoms. Numbers are caught on the Porcupine Bank, West of Ireland.

\section{Life-History}

The life-history of the coalfish is given by Hjort. ${ }^{1}$ It spawns from January to May, for choice, at depths from 50 to 100 fathoms, and generally at 80 fathoms, on the slopes of the coastal banks, just as does the hake. But whereas hake spawn almost entirely in the Atlantic, the spawning grounds of the coalfish have been located in the Atlantic, in the North Sea, and in the Norwegian Sea. The North Sea spawning grounds are confined to the northern extremity of the banks north-west of Shetland, and the deeper portion and extreme edge of the Romsdal Bank - the grounds known to Norse fishermen as Tampen. Here many hundreds of hauls with tow-nets have found the surface covered with thousands of eggs in the early part of the year. Hjort notes that the eggs float only in water of 35 per mille salinity, i. e. very salt indeed. There is usually ${ }^{2}$ little water as salt as this, except in the central portion of the North Sea north of the Tees-Skaw line in February, and off the Shetland Banks.

Very soon after spawning has taken place, both the large coalfish and their eggs ${ }^{3}$ completely disappear from the spawning grounds. The period of incubation is said by the Americans to be nine days at $43^{\circ} \mathrm{F}$., and six days at $49^{\circ} \mathrm{F}$., which is about a week shorter than the hatching period of cod. The fry similarly float at the surface for a much shorter period than cod-who may be drifting for as much as three months.

1 Some Results of the Internationa Ocean Researches, Scot. Ocean Lab., Rutland Street, Edinburgh. Depths of Ocean, Chap. X.

${ }^{2}$ But in 1904 apparently the abnormal influx of Atlantie water made the North Sea unusually salt.

3 The eggs are $\cdot 044$ inch in diameter, i. e, about 795,000 to the quart. 


\section{P L A T E V I I}

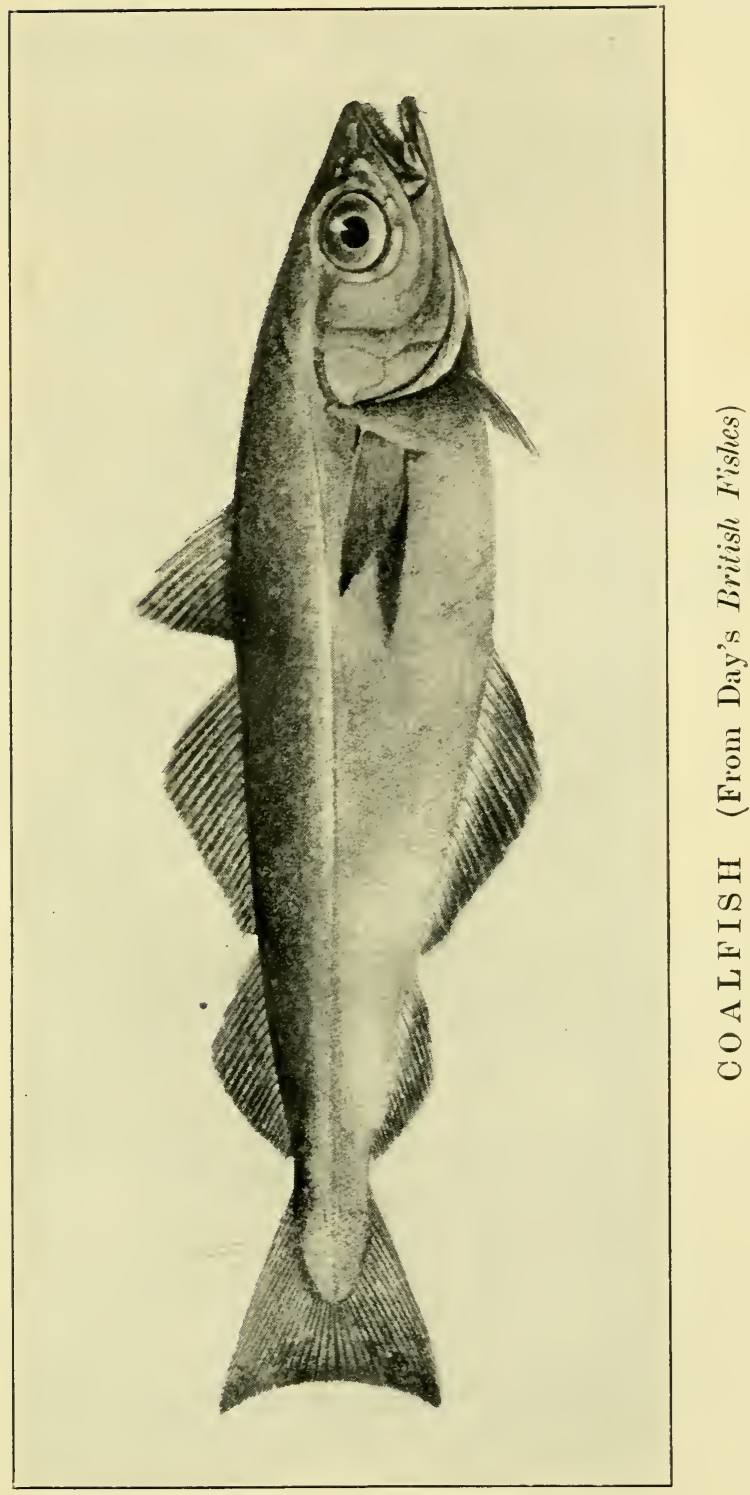





\section{The Fry Stage}

Coalfish go to the bottom very much more quickly than cod. For instance, the eggs and fry were found drifting by Schmidt south of Iceland in the same water as those of the cod; but the saithe fry do not drift nearly so far round the south coast as the cod; and do not appear to get beyond Sigluf Bay-while the cod are carried right on to the east coast by the current (see Fig. 7). The fry drift shoreward in the North Sea early in

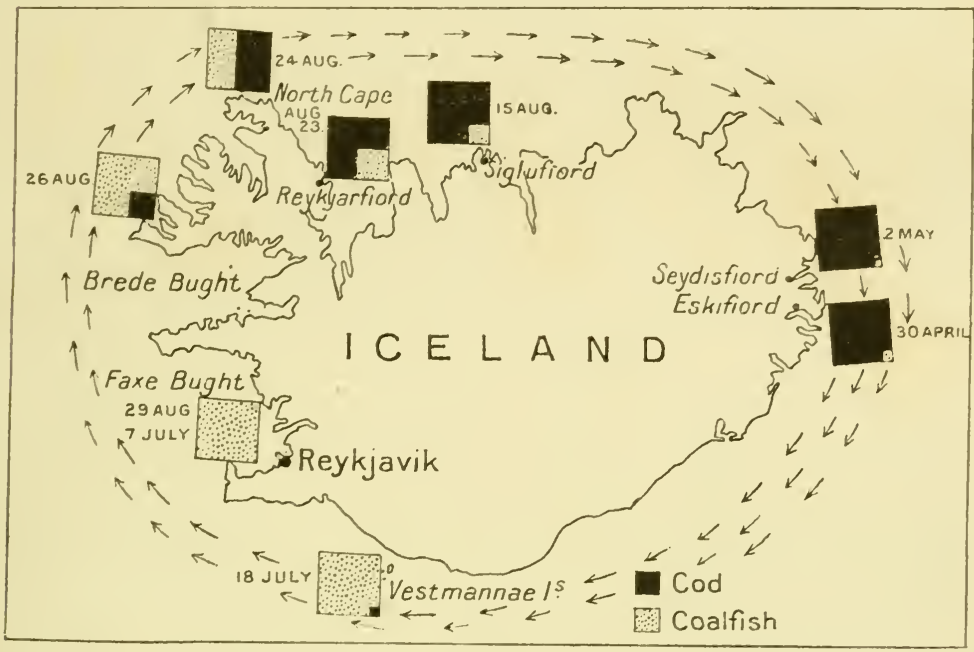

Fict 7.-Relative numbers of coalfish and cod at the stage when the fish cease to float at the surface with the current, and take to the bottom. Both species spawn on the south-west coasts. The cod spend a long time at the surface and are plentiful on the north and east coasts. The coalfish nearly all go to the bottom while they are still off the south or west coast. (From Depths of Ocean.)

summer, and later appear to swim inshore up to September; they are found at the bottom, in places very far removed from their spawning grounds, on the Scottish and English and Norwegian coasts, and have been found (in September) even out in the Arctic Deeps between Bear Island and Norway. No very small fry have been found in the south of the North Sea owing to the easterly set of the current, or in the Skagerrakwhere all the water salt enough to suit saithe eggs and fry is at the bottom. The scales are easily read. 


\section{Growth of the Fish}

The growth varies enormously. Skagerrak saithe $1 \frac{1}{2}$ years old were found to measure 15 inches; Murmansk fish were only 11 inches at $2 \frac{1}{2}$ years.

An experimental catch of 645 fish caught by Hjort at Bredsund near Aalesund gave :

(a) In summer, fish of from three to eight years old, the majority being four, five, and six years.

(b) In winter, fish of from six to eighteen years old, the majority being seven, eight, and nine years.

The growth is, in suitable waters, fast and regular. The fry have been found by McIntosh to average $1 \frac{1}{8}$ inch in May and June at St. Andrews. In May at the Faroes they measured $1 \frac{1}{8}$ inch to 2 inches ; in July on the average $3 \frac{1}{2}$ inches ; in September $4 \frac{1}{2}$ inches. Off northern Ireland they measured $3 \frac{1}{4}$ to $3 \frac{1}{2}$ inches in May and June. Damas has proved that growth on the Norway coast is much slower in high latitudes than farther south. At Romsdal he found the average size to be :

$$
\begin{aligned}
& \text { Inches. }
\end{aligned}
$$

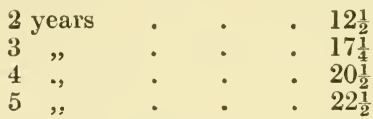

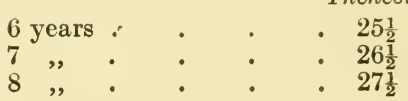

and he has caught coalfish up to eighteen years and $39 \frac{1}{2}$ inches. The lessons which Hjort drew from the life-history of the saithe were :

(a) the power of ocean currents to carry fry from the Atlantic or North Sea to the Arctic Ocean, and-

(b) the fact that coasts hundreds of miles in extent are dependent for their fish supply upon spawning in distant waters.

This humble species is a warning against the false thinking implied in the use of such terms as 'local researches' and 'local fishes' in connexion with market fish of wandering habit. 


\title{
CHAPTER XIX
}

\author{
THE HALIBUT
}

The 1913 Catch (Analysed)

Tons.

$\mathfrak{E}$

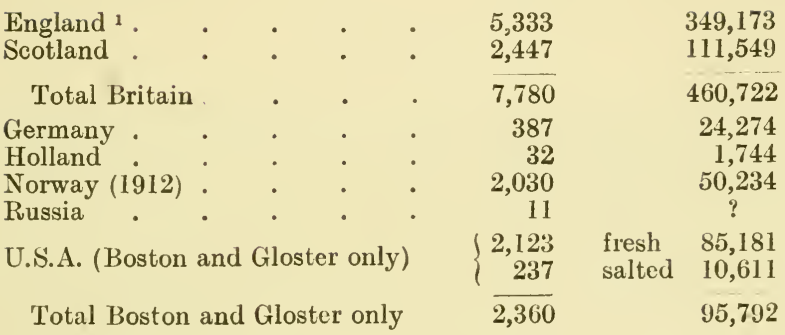

\section{British Catch (Analysed)}

I'he chief landings were made at:

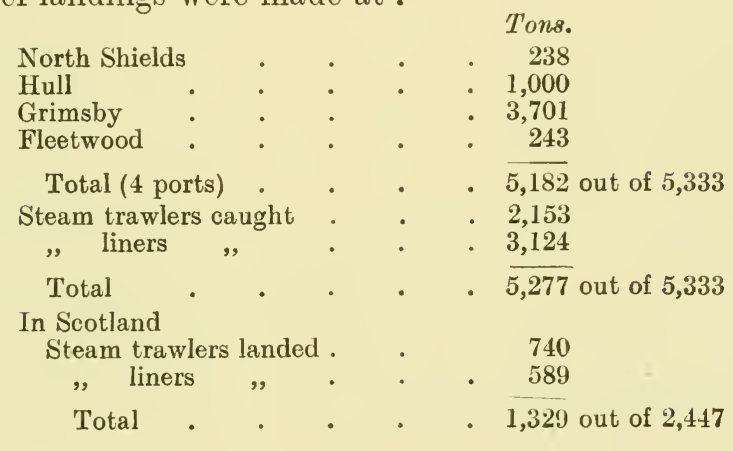

The English Halibut Grounds

The chief halibut-grounds were:

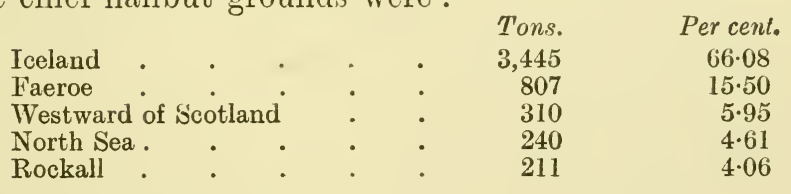

1 In 1920 the landings were :

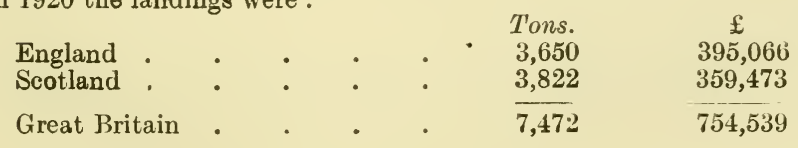


The Shetland grounds are also prolific.

The fish is therefore a steam liner and trawler ${ }^{\mathbf{1}}$ fish ; and a ' deep sea' fish.

Hjort analyses the cateh as follows:

$$
\text { Per cent. }
$$

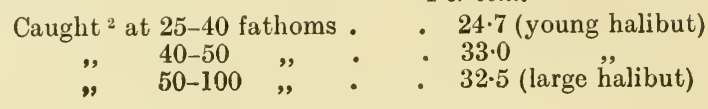

\section{Life-History}

The ripe eggs (first found in May 1892) are very largeaveraging about one-eighth inch in diameter. ${ }^{3}$ The staff of the Danish steamer Thor under Dr. Schmidt has worked at the lifehistory of the fish, but the writer can find no reference in English to the finding of eggs actually floating at sea, though the fact that they do so float is assumed. In May $1892 \mathrm{Mr}$. R. Mackie of Peterhead obtained ripe eggs from an 18 or 20-lb. fish on the Bergen Bank 60 to 100 miles south-east of Lerwick in the Shetlands. On the 5th May $1893 \mathrm{Mr}$. Duthie caught a ripe female of $22 \mathrm{lb}$. on the Bergen Bank, but not until it was too late to fertilize her eggs. These two discoveries fixed the spawning period for the Bergen Bank at the end of April and beginning of May. It is believed that male halibut ripen both earlier in the year and at a smaller size than the hens. The S.S. Thor found the larvae in the sea off the south and south-west coast of Iceland in May and July; and the Icelanders commonly assert that Faxe Bay on the south-east coast is a great nursery ground for 'baby halibut'.

It is believed that the Iceland Government would like to close this Bay against steam trawlers in order to protect this 'nursery'. So the urgency of complete understanding and explanation of the life-history is apparent. The big fish apparently to some, extent prefer rocky bottoms-where the trawl cannot operate. So far as the writer can discover, the only record (in English at any rate) of any attempt to read halibut scales or to "age ' the fish at different stages of development is that of Mr. Storrow, to which reference is made below.

People who exploit Iceland and Faeroe waters would study with great interest any accounts which could throw light upon the habits of this species-the 'prime fish' of the northern

\footnotetext{
1 Sailing smacks and inshore fishermen between them landed 5 tons in England.

${ }^{2}$ Depths of Ocean, p. 451.

${ }^{3}$ See British Marine Fishes, p. 316. The eggs vary from 3.07 to $3.81 \mathrm{~mm}$., and were 'perfectly ripe' at $3.3 \mathrm{~mm}$. About 32,000 would be contained in a quart.
} 


\section{PLATE VIII}

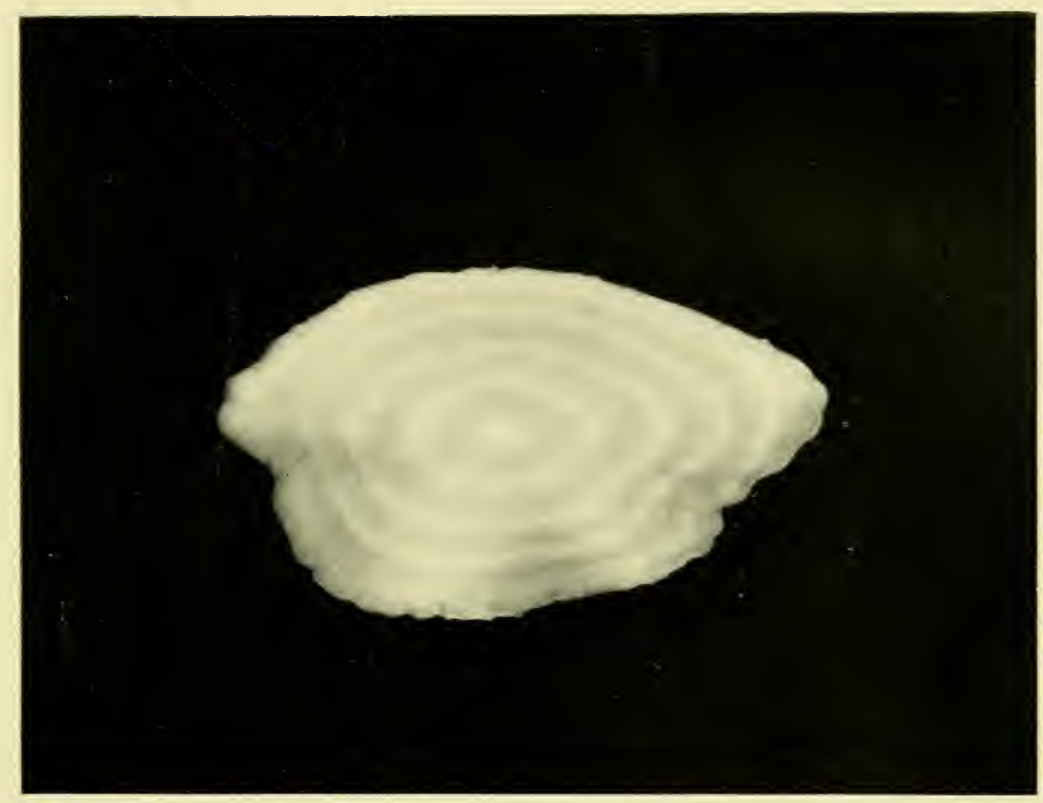

H A L I B U T O T O L I T II

(Photograph by B. Storrow.) 

seas. For halibut since the war have become nearly as popular as turbot in the British Isles, and it is one of the most valuable and interesting as well as the largest of all the fishes landed on our shores.

There is no English record of the development and hatching of the egg, the growth and development of the fry, their wanderings and food, or the habits of the adult halibut. Here, therefore, is an extremely valuable fish for whose protection at any moment restrictions on fishing may be proposed. Have the data been collected on which a reasoned judgement could be based? If so, can they be made known to British fishermen who catch most of the European supply? If not, is it not time to collect them?

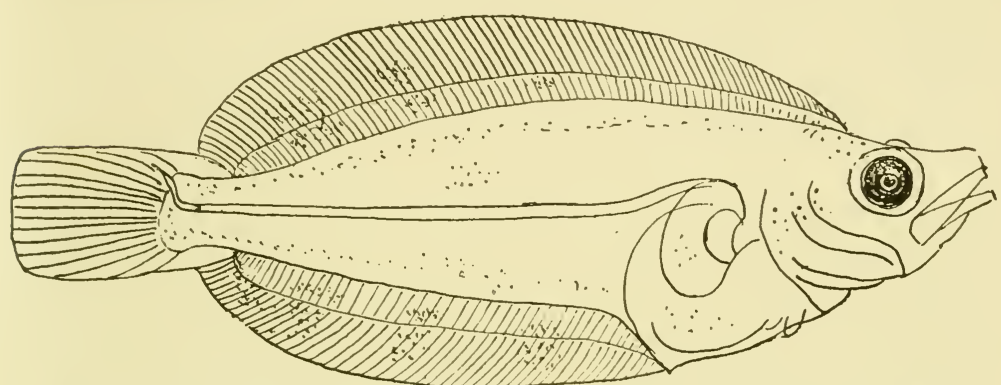

Fig. 8.-Baby halibut $\frac{9}{10}$ inch long. Drawing (after Schmidt) from Meek's Migrations of Fish.

\section{Greenland Halibut}

An American liner in 1911 caught over 62 tons of halibut which sold for $£ 2,459$ in a single voyage off the coast of Greenland. The voyage is reported on p. 49 of the Anmual Report of the U. S. Commissioner of Fisheries, 1911. This seems to indicate the desirability of an exploratory voyage to test the potentialities of the Greenland Banks.

\section{Mr. B. Storrow's Halibut Investigations}

Very valuable observations on the halibut were made in 1916 by Mr. B. Storrow, of the Dove Marine Laboratory at Cullercoats, Northumberland. He examined the ear stones of fortyeight fish. As is shown in the illustration (Plate VIII), which is a photograph of the ear-stone of a fish $22 \frac{3}{4}$ inches long, the annual growth is very distinctly marked, and this particular halibut was five years old, and just beginning to put on its summer growth. It was landed on the 10th April 1916. 
The average sizes of the forty-eight halibut examined was as follows :

\begin{tabular}{cccc|cccc}
$\begin{array}{c}\text { Number } \\
\text { of fish }\end{array}$ & $\begin{array}{c}\text { Average } \\
\text { length. }\end{array}$ & $\begin{array}{c}\text { Fish } \\
\text { hatched out } \\
\text { in year. }\end{array}$ & $\begin{array}{c}\text { Number } \\
\text { of fish }\end{array}$ & $\begin{array}{c}\text { Average } \\
\text { length. }\end{array}$ & $\begin{array}{c}\text { Fish } \\
\text { hatched out } \\
\text { in year. }\end{array}$ \\
2 & 3 & $12 \cdot 3$ & 1914 & 7 & 2 & $33 \cdot 9$ & 1909 \\
3 & 1 & $17 \cdot 3$ & 1913 & 8 & 8 & $38 \cdot 3$ & 1908 \\
4 & 4 & $18 \cdot 5$ & 1912 & 9 & 5 & $39 \cdot 2$ & 1907 \\
5 & 17 & $29 \cdot 6$ & 1911 & 10 & 4 & $41 \cdot 9$ & 1906 \\
6 & 3 & $27 \cdot 1$ & 1910 & 11 & 0 & 0 & 1905 \\
& & & & 12 & 1 & $46 \cdot 8$ & 1904
\end{tabular}

This characteristically excellent piece of work at the small Cullercoats station is a good example of the kind of investigations which can be of real assistance to the deep-sea fishing industry. Cullercoats, unlike most other marine biological stations, is situated within easy reach by tram of a deep-sea fishing port, and its workers are always in touch with the owners and skippers of deep-sea vessels. This may account for the fact that its staff seems never to lose sight of the possible economic bearing of its researches. Mr. Storrow's halibut material was probably too limited to justify any very definite conclusions. But it does show that a useful line of investigations could be followed up with little trouble and at small expense. We want to know whether broods of halibut are wiped out in certain years on the grounds our vessels fish; whether in certain years there is an abnormal survival of baby halibut, and whether the babies thus nursed by nature through the dangerous period survive to great age. These are facts which could obviously enough be determined by collecting the ear-stones of large numbers of halibut from all the different grounds, and working out the results as Mr. Storrow has done. The factors which make a 'good' or 'bad' halibut season can probably not be ascertained otherwise than by observations made from research vessels of currents, temperatures, and salinities, and their effect upon the baby food in the waters in which the eggs actually hatch out; but these observations could, of course, be combined with work on other species. Here is work immediately to be undertaken-the first part of it by British investigators ashore, the second part by such research vessels as the International Council may be able to detail for the purpose. Once fishing skippers understood the object and meaning of the ear-stone examinations, collections and data would flow into the hands of the investigators, and the flow would continue, provided always that the men were told the results. Hitherto the complaint has been-and it is so common that it can scarcely be baseless - that men who report marked 
fish, or drift bottles, or other data interesting to scientists; hardly ever hear of the results of their find. So this chapter closes on the same note as other chapters. So long as ocean research workers and fisher-folk regard each other as beings inhabiting distinct spheres of activity, so long will the present unhappy state of things continue. Marine science will be regarded as the preserve of a small and exclusive mutual admiration society; and fishermen, for lack of direction, will continue to draw unreliable conclusions from unsystematic premises. 


\section{CHAP'TER XX}

\section{'THE CA'TCH OF' HAKE}

\section{The European Catch}

Is his pamphlet ${ }^{1}$ on the hake published in June 1920 Dr. Le Danois estimates the average pre-war landings by the fishing nations roughly as follows:

\begin{tabular}{|c|c|c|c|c|}
\hline & & & & Tons metric. \\
\hline England & . & - & - & 35.000 \\
\hline Scotland & & . & . & 1,000 \\
\hline Ireland & . & . & . & 300 \\
\hline France & . & . & . & 2,000 \\
\hline Germany . & . & . & . & 900 \\
\hline Netherlands & . & . & . & 400 \\
\hline
\end{tabular}

Hake is a staple fish also in Spain, Portugal, Italy, and Greece, but statistics for these countries are not available. The main hake grounds produced on the average, according to Le Danois, the following amounts:

1. South of Ireland and mouth of Channel .

T'ons metric.?

20,600 average

2. West of Scotland, Bristol Channel, and Irish Sea . . 6,000 ,

3. Spain, Morocco, Mediterranean, \&c. . . 3,700 ,

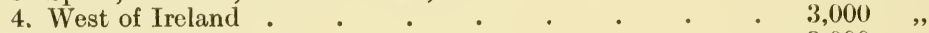

5. North Sea . . . . . . . . . 3,000 ,

6. Bay of Biscay . . . . . . . . 1,400 ,

\section{- The British Catch ${ }^{3}$ (Anulysed)}

In 1913 the comparative catch was as follows:

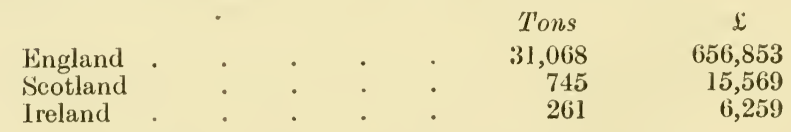

1 Notes et Memoirs, No. 2 b. Le Merlu, ed. Le Danois, Docteur de Science, Office Scientifique des Pêches Maritimes, 3 Avenue Octave Gréard, Paris.

2 A ton metric is 0.9842 of a British ton.

3 In 1920 the landings were:

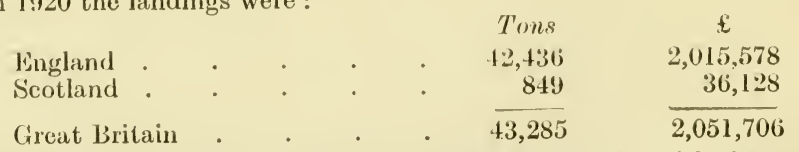

This is the largest catch for any year from 1906 onwards, with the exception of 1909 ( 44,581 tons). 
The following ports landed over 1,000 tons:

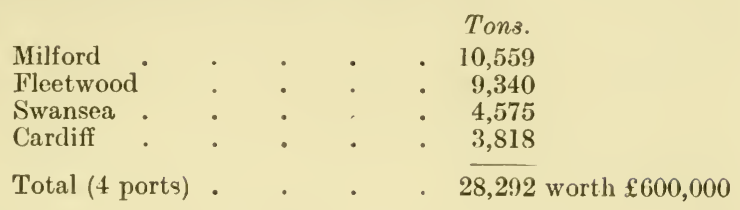

The only other considerable catches were landed at Plymouth (872 tons) and Hull (572).

In Scotland, Aberdeen landed 861 tons.

The growing demand for hake in the British Isles, which is reflected by the steadily rising price, was created by the "Fish Friers' towards the end of the last century. It is therefore a 'new' industry ; a 'South-Western area 'industry; a steam trawler industry ; and a British industry.

In 1913 hake formed 7.43 per cent. of the catch of bottom fish. 57.91 per cent. came from the southward of Ireland; 15.55 per cent. from the westward of Scotland; 12.75 per cent. from the westward of Ireland ; $7 \cdot 00$ per cent. from Portugal and Morocco ; 2.73 per cent. from the Irish Sea ; 1.43 per cent. from the Bay of Biscay; and 1.05 per cent. from the Bristol Channel.

They formed 74 per cent. of the catch of trawlers on the Portuguese and Moroccan grounds ; 58 per cent. in the Bay of Biscay ; 54 per cent. to the south of Ireland; and 50 per cent. to the west of Ireland. These are the regions fished by "hake boats'. Elsewhere they were only an incidental portion of a catch of other fish.

\section{Fluctuations in the Catch}

Hake-fishing, like most other forms of fishing from ' dry fly' downwards, is according to its votaries perpetually 'going to the devil'. Hake are "easily scared '; "very sensitive to heavy fishing'; 'easily fished out ' - and so forth. We shall see that in the nineties hake 'disappeared' from the 'Smalls' off Milford Haven, but are now being caught there in great numbers. A similar catastrophe overtook the hake fishermen of Cap Breton, ${ }^{1}$ to the north of Biarritz, early in this century, "the fish persistently and increasingly deserting the coast, and the fishermen being without the means of going in search of them in the deep bottoms'. At first, of course-as is the way of fishermen-the man with the latest gear was blamed as a 'poacher', so it was the steam-trawler who did it. But, says

1 M. A. Hérubel, Sea Fisheries, p. 102 (1912). 
Dr. Hérubel, ' in 1891 the increasingly large takes of hake in the Bay of Biscay gave the direct lie to the accusation '.

From the detailed figures which follow it will be seen that a good year in 1909 on the main grounds to the southward of Ireland, on the 'South Hake Ground', the 'Cockburn Bank', and on the westward portion of the 'Great Sole Bank', for instance, was followed by two very indifferent years. But in 1912 the average daily catch per trawler was even heavier than in 1909. Meanwhile, a little farther to the north and west on the Porcupine Bank, and the grounds round about the 100fathom line off Clare and Mayo and Galway, ${ }^{\mathbf{1}}$ the gross catch was steadily increasing, and the daily average in 1913 was higher than in any of the previous four years. Farther north again, along the 100 -fathom line northward from the line west of Erris Head (in Mayo) and all along the regions dubbed 'Westward of Scotland', the gross catch showed no falling off, while the daily catch per trawler steadily improved.

If the whole of these waters be taken as forming part of one huge fishing-ground-an assumption quite legitimate in the case of an ocean rover like the hake-we get the following figures of gross catch : ${ }^{2}$

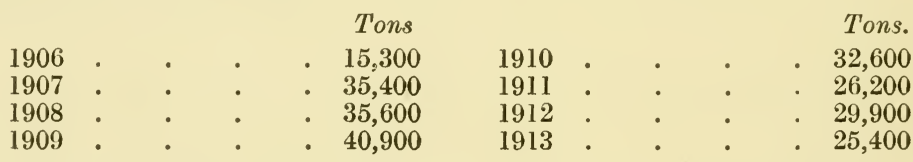

Did this mean that there were fewer hake in the Atlanticor that skippers could not find them?

It is possible, of course, to argue that the hake were being fished out; or that they were shifting their rendezvous farther north, because they found trawling made things uncomfortable. This, to the writer's mind, is to fall into the common error of endowing fish with a reasoning power which they probably do not possess. It would be quite legitimate, surely, to inquire whether the true explanation were not just this-that some impulse as yet undiscovered, but not in any way connected with the operations of mankind, had caused the shoals to shift, and that the trawler skippers, although equipped by their owners with the materiel to exploit the new spawning grounds, had not, as yet, been equipped by naturalists with sufficient knowledge to enable them to find the fish.

Figures, the writer has been warned, 'overload' a book and spoil it. So much loose thinking and loose talk about fisheries,

1 The Bay of Galway is marked on old maps ' The Bay of Hakes'.

${ }^{2}$ It must not be forgotten that this fishery practically dates from 1903 only. 
and especially about hake-fishing, has resulted from this dread of statistics, that he prints the following tables in full, without any apology, and commends them-and the quinquennial ${ }^{1}$ statistical tables of the Board of Agriculture, from which most of them are taken-to the very careful consideration of every one interested in the catching of hake. Are the hake in the Atlantic getting fewer in numbers? Or are there roughly as many hake in one year as in another? Or are there certain years in which baby hake, like young herrings and cod and haddock, escape the holocaust which is their normal fate? And if the population does not fluctuate, where are the shoals when they are not to be found on such hake grounds as have been discovered? And, above all, in each case-what is the cause? Those are the questions which fishermen, and naturalists, and politicians (if by some miracle the latter ever awake to the potentialities of ocean research) should keep always in front of them.

\section{Table showing Fluctuations on Main Hake Grounds}

Sovth of IrELAND.

\begin{tabular}{|c|c|c|}
\hline & & Tons. \\
\hline $\begin{array}{l}1906 \\
1907\end{array}$ & . & $\begin{array}{r}14,310 \\
\cdot \quad 33970\end{array}$ \\
\hline 1908 & . & $\begin{array}{l}. \quad 33,500 \\
\end{array}$ \\
\hline 1909 & • & . 36,820 \\
\hline 1910 & . & . 27,710 \\
\hline 1911 & . & . 20,530 \\
\hline 1912 & • & . 22,910 \\
\hline 1913 & • & . 17,090 \\
\hline
\end{tabular}

Westward of SCOTLANd.

$$
\text { Tons. }
$$

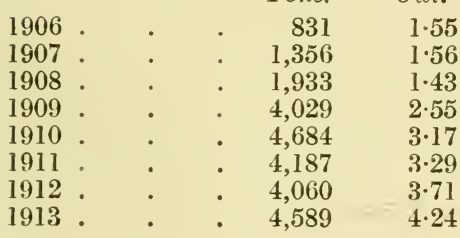

WEST OF IRELAND.

\begin{tabular}{|c|c|c|c|c|}
\hline & & & Tons. & $C w t .^{2}$ \\
\hline 1906 & . & . & 208 & $1 \cdot 27$ \\
\hline 1907 & & & 145 & $16 \cdot 52$ \\
\hline 1908 & . & . & 242 & $9 \cdot 40$ \\
\hline 1909 & . & • & 74 & $9 \cdot 46$ \\
\hline 1910 & . & & 271 & $13 \cdot 86$ \\
\hline 1911 & 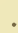 & . & 1,530 & $12 \cdot 62$ \\
\hline 1912 & . & • & 2.952 & $11 \cdot 70$ \\
\hline 1913 & . & . & 3,762 & $15 \cdot 3$ \\
\hline
\end{tabular}

Bay of Biscay.

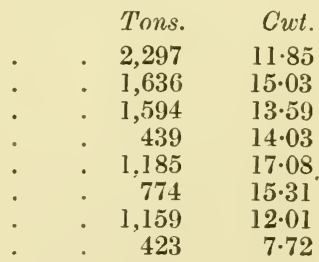

Portugal and Morocco.

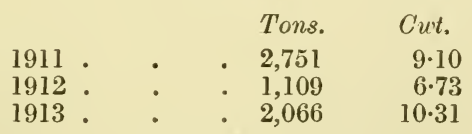

1 These are really invaluable because they give the monthly catches.

' $C w t$ '. are cwt. caught per trawler per day's absence from port. 


\section{The Range of the Hake}

Le Danois puts the southern boundary of the European hake in lat. $20^{\circ} \mathrm{N}$. at Cape Blanco ; the northern limit is, he says, somewhere about $62^{\circ} \mathrm{N}$. - that is somewhere to the north of the Faeroe Islands and of Trondjhem Fjord. Mr. C. Curzon, of Milford Haven, however, informs the writer that he has seen large quantities of hake caught in the Bight of Benin, at about $5^{\circ} \mathrm{N}$.; and as a variety known to Science as Cape Hake (Merluccius capensis) occurs off the Cape of Good Hope, it seems possible that our hake species, or their close relations, extend continuously right down the coast of Africa into the Southern Hemisphere. The water temperature in the Bight of Benin at 50 fathoms is given by Helland Hansen at $57^{\circ} \mathrm{F}$. to $60^{\circ} \mathrm{F} .1$

Hjort, during the cruise of the S.S. Michael Sars in April and May 1920, caught hake in the trawl as follows :

(1) at 70 and 90 fathoms on the 'coast bank' west of the Lizard in the neighbourhood of $10^{\circ} \mathrm{W}$. and $49^{\circ} \mathrm{NW}$. ;

(2) off Vianna in Portugal on a bank, where a Boston trawler was at work in $30-40$ fathoms-temperature about $48^{\circ} \mathrm{F}$.;

(3) at 70 fathoms on the coast bank below Cape Spartel, where seven trawlers were fishing in the beginning of May ;

(4) a short distance seaward of the last point in 300 fathoms - temperature about $53 \cdot 6^{\circ} \mathrm{F}$.; and

(5) at 150 fathoms west of Cape Bojador-temperature about $57^{\circ} \mathrm{F}$.

At Bojador itself, about the 20th May, the Spanish fishermen from the Grand Canary caught Dr. Hjort some hake fry in a sardine seine worked from the shore.

His general conclusion was that the hake and other ' coast fishes 'do not inhabit grounds covered with much more than 300 fathoms of water, and as he trawled regularly at 500 fathoms and over, and caught quantities of 'deep-water' fish like 'Macrurus' and 'Mora '-which are, he tells us, commercially about as valuable as torsk-below 300 fathoms his conclusions are unlikely to be challenged. At 300 fathoms he found a fairly uniform temperature of $50^{\circ} \mathrm{F}$. The important thing from the point of view of the fishermen is to know when hake may be found in abundance on any particular bank in the huge ocean area which it frequents.

\section{The Hake 'Seasons'}

On p. 26 of his pamphlet Le Danois prints a table which gives some useful information on this point as follows: 
Coasts of Morocco and Spain, Mediterranean .

North coast of Spain and southern portion Bay of Biscay

Southward of Ireland, i.e. edge of Continental Plateau $\left(46^{\circ}\right.$ N. $-48^{\circ}$ N. $)$.

Entrance to English Channel $\left(48^{\circ} \mathrm{N} .-51^{\circ} \mathrm{N}\right.$.). .

West Coast of Ireland (Porcu. pine Bank)

Rockall and westward of Scotland

Orkneys

West coast of Scotland :

North of North Sea :

Middle Grounds +

Witch Grounds

South of North Sea

Cattegat and Skagerrak .

Shetland

Faeroe
Froms

Best Month

November-February January

November-May

December ${ }^{1}$

March-June

April-September

May-September

June-October

June-November

July-October ${ }^{3}$

June-November *

July-October

July-September

August-October

October

August
May

June

July $^{2}$ 。

August-September June-November July

June-November ${ }^{5}$

October

October

October

This table is not more than very roughly accurate. On the main hake grounds, for instance, to the southward of Ireland the climax of the fishing is more usually in June or July than, as it was in 1910, in May. From 1906 to 1909 inclusive, October and November were consistently the best months to the westward of Scotland; January, February, March or April in the Bay of Biscay and off the north coast of Spain ; the Porcupine Bank supplies hake chiefly from August to December. It appears, in fact, that Le Danois has argued from the state of things in, or subsequent to, 1910. But the detailed figures contained in the statistical tables for the years 1906-10 (published by the English Board of Agriculture and Fisheries in 1912) show that the shoals vary the time of their arrival considerably, and leave in some years very much earlier than in others. What is the cause of these variations? It has long been the opinion in the English fishing industry that hake are extraordinarily ' capricious ', and very easily fished out. But it remains to be proved that the fluctuations are solely, or even primarily, due to the

1 This should probably be February, March, April.

2 This should probably read August.

3 This should read April to October.

4 This should read April to December.

5 This should read October to November. Dr. Bowman informs the writer that the years 1903,1904 , and 1905, and more particularly 1904, were apparently favourable years for the invasion' of the North Sea by hake. Is it mere coincidence that 1904 was also an unusually prolific year for cod, haddock, and herring? Do all these phenomena alike depend on the volume and direction of flow of the Atlantic stream? 
operations of fishing-vessels. This year, for instance, there occurred a positive glut off the 'Smalls'-some thirty miles from Milford Haven Heads-for about nine weeks from August to October, near the region which Le Danois calls ' Entrance of the Channel'; here the hake were following up a great school of unusually large herrings, which had never been caught off the Smalls before. This is ground which used to be immensely rich in the late 'eighties', but, as we shall see, was supposed by the trawler owners to have been 'fished out' shortly afterwards.

Then, again, for the first time in living memory quantities of hake have been caught off the Irish coast between Waterford and Cork, as this is written during December 1920. They are feeding on mackerel, and their flesh is consequently so soft and oily that they do not keep at all well off ice.

\section{The Wanderings of the Hake}

It is clear, however, that hake put in an appearance in shoals at different times in different regions. As we shall see, the industry has been at pains to explain these movements, and more than one inquirer has suggested that the movements of the hake might depend upon the movements of the fish-the herrings, mackerel, pilchards, and poutassou-on which they are wont to prey. Hunger is, however, certainly not the only impulse behind these movements; and Le Danois is of the opinion that the decisive factor is the reproductive instinct. His explanation is worth giving in detail for the benefit of brother laymen. 'The body of the young fish', he says, 'has a fairly heavy density in comparison with sea-water, for it consists practically entirely of close tissues-largely muscular; when the genital glands develop, the fish undergoes a diminution in the density of its body, and the salinity and temperature of the waters in which it usually lives compel it to make great efforts in swimming. It proceeds to look for waters less dense, less salt, and less cold-and this search-due to the principle of minimum exertion-brings the fish towards our coasts, and towards shallower depths. In fact the surface waters of the Continental ${ }^{1}$ shelf are marked by a higher temperature and a weaker degree of salinity than the waters of the great depths.'

Le Danois is inclined to reject the old theory that the shoals moved in search of particular kinds of animals suspended in the water-particular kinds of 'plankton' as the scientists would say. He thinks that a fish which finds itself in waters

1 i.e. the sea floor between the shore and the 100 -fathom line. 
which are not its normal home, under the influences described, would, if necessary, change its diet and eat what it could find. This is what one would expect, cortainly, of a fish like the hake which has not undeservedly earned the name of 'sea-pike' by its voracity (Mr. Rees has taken twenty-four herrings out of a hake of about $14 \mathrm{lb}$.). Moreover the intestine of the fish is practically blocked when its genital glands are full of spawn or milt, and it probably eats little at these times. Thus we get the first movement of the spawning shoals from the depths which are their home to the warmer shallows where the density of the water is less. This journey is one of concentration ; that is to say a large number of fish crowd together in a small space so as to ensure the fertilization of their eggs. Then comes a 'deployment' at the end of the breeding season. The shoals break up and return home to the deeps where they can find plenty of food.

Le Danois sums up thus :

1. That hake are caught chiefly while they are actually spawning, i.e. on the journey of concentration. At this time they frequent waters of the temperate zone and middle depth.

2 . The normal home of the hake shoals when they are not breeding is at greater depths, in waters which are colder and more saline, and to the northward of the spawning grounds.

3. The farther south, the earlier the spawning schools will appear.

4. After the breeding season the hake disperse to look for food on the bottoms where they reside between whiles.

The writer would inquire whether, before the return journey is carried out, the shoals do not linger-at any rate sometimesin shallow water, in order to feed themselves up after the exertions of spawning. The 'mending' process might explain the summer invasion of the North Sea ${ }^{1}$ - where (apparently) the hake do not spawn-at any rate with any freedom, but where they seem to 'shoal' in pursuit of the herring from June till the North Sea gets too cold for them in November. It might also explain the extraordinary raid on the mackerel of the south coast of Ireland made by hake this winter (1920).

This ' recuperative' journey would naturally depend largely on the movements of the herrings and such other 'game' as the exhausted hake prescribed as their dietary!

1 Dr. Bowman has 'never seen a female hake with the eggs in the ovaries fully developed and ready for extrusion' landed at Aberdeen, though 'the invading hake are all well-grown fish, many with maturing sexual organs'. So the writer's amateur hypothesis must be abandoned! 


\section{CHAPTER XXI}

\section{BUSINESS MEN ON HAKE PROBLEMS}

\section{Mr. C. C. Morley on Hake Fisheries}

The minutes of Mr. Tennant's Committee on Fishery Investigations (Cd. 4304, 1908) contain some interesting evidence on the development of the hake fishery. Mr. Morley, Managing Director of the Southern Steam Trawling Company of Waterford, explained that Milford vessels in the late "eighties ' used to find great quantities of hake in the summer "off the Smalls. Then we apparently killed the hake that came in there, ${ }^{3}$ and we thought that that hake came in from somewhere, so we gradually extended our fishing to try and meet the hake coming in'. They met it. 'First at the Longships, off down Land's End way; then in the Bay of Biscay; then (in December and January) off Cape Finisterre; and finally down in Morocco.'

' Now we meet it practically all the year round on the edge of the deep water, about 270 miles west by south from St. Anne's Head. We have nothing to guide us as to where that hake breeds, or where it comes from. I think (though this is a matter for scientific investigation) that one of the main causes of the herring fishery on the south coast of Ireland being not so good as it was, is that we are killing the hake as it comes in, and drives the herring into the coast; we know from opening out the guts of hake that there is nothing they are so fond of as herring spawn, and that is one reason we think the herring fishery on the coast of Ireland has failed.'

He explained how the new 130-foot hake-trawlers carried two miles of warps on their big winches. He noted that the Morocco hake (off Cape Blanco) was oily and soft, and did not sell nearly as well as the deep-water hake caught out to the westward in 200 fathoms. Summer hake, he said, was always softer than winter hake. He had seen no signs of depletion. He had seen a great deal of small hake landed from Morocco, but 'apparently when we get below Cape Blanco we do not get the English fish at all '.

Mr. Morley had chartered a big ship and himself gone down to find out what the Portuguese knew about hake. He had spent a day with the King of Portugal and one of his professors

1 This theory is interesting, but surely presupposes a very much greater destruction of hake than actually takes place. 
(unnamed). They were 'of opinion that the hake breeds on what they call the Continental plateau, which is somewhere down between Morocco and Madeira, and gradually works its way up the coast to the edge of the deep water, to get into the feeding on the shoal ground'. $\mathrm{He}_{\theta}$ had tried the Mediterranean ${ }^{1}$ between Gibraltar and Algiers for hake, and found only a few small ones, and 'a few baby hake up as far as Barcelona on the Spanish coast'. Morocco, he said, was the main hake ground for the big ships, but "now we are getting hake about 270 miles west by south from St. Anne's Head; that is, on the edge of the deep water'. In the cold weather his ships always had to go into deep water for fish. His skippers found that in rainy weather it was easier to catch fish off Waterford Harbour. Was this because the water became turbid? Or does the diminution in salinity attract the spawners?

$\mathrm{He}$ explained that the deep-water fishery was first started about 1903 . It was carried out about 270 miles $W \frac{1}{2} \mathrm{~S}$ of Land's End, and also 100 miles W $\frac{1}{4} \mathrm{~S}$ of the Fastnet. He explained that they caught herrings - the prey of the hake-in trawls at 60 fathoms, but only in very hot weather ; and that the hake came up (especially at night) to take the herring.

$\mathrm{He}$ reiterated his opinion that the hake really affected the migration of herring. They found hake, he said, "when the herring is off Ireland, and we find the hake full of her ring spawn; you can always tell the fish that has fed on herrings; he is so fat and oily'.

$\mathrm{H}_{\theta}$ suggested that the hake might breed at about 1,000 fathoms. They got a fair quantity of 'baby hake', i.e. hake about 10 inches long; but they never got any very small ones-and none, for instance, as small as 6 inches. These baby hake were caught at the edge of the bank (along with the big ones) off to the southward of Ireland-that is to say, in the neighbourhood of the 'Smalls '.

As to migrations, Mr. Morley said that they 'lost' the hake often in July, and that it appeared up at the Moray Firth in August. Nobody caught hake in the English Channel from the Smalls up to the Moray Firth, ' and nobody knows how it goes up to the Moray Firth; as far as we know, the theory is that it swims off the ground, and we cannot get it'.

1 M. Paul Gourret noted in 1894 that big hake were rarely caught off Provence, and that the species was decreasing (Les Pêcheries et les Poissons de la Méditerranée (Provence), Paris, Baillière et Fils, 1894, p. 355). But the writer would like to see the African coast of the Mediterranean tried for hake, for it is along this coast that the current sets in from the Atlantic and flows to the eastward. 
Mr. Morley did not mention the theory that the hake, after raiding the Stornaway herrings, follow the Atlantic water round the British Isles through the Pentland Firth, and so are caught off the Skagerrak in August. His evidence was thus suggestive of many questions which research workers might try to answer. And he entered a strong plea for the institution of research into the life-histories of hake, 'Southern Ling', bream, and other fishes of the south-west area. He was very strongly supported by Mr. J. J. Neale, of Cardiff, and Mr. R. C. Ward, of Fleetwood.

\section{Mr. J. J. Neale on Hake Research}

Mr. Neale told the Committee that he and his sons were prepared to give free quarters on their big trawlers to any research workers who would go down to study the fishing ' on the Morocco coast, or the Spanish coast, the Portuguese coast, or down to the Bay of Biscay'. No scientists, he said, had been out on commercial trawlers working these grounds, which produced most of the hake and bream landed, and a heavy proportionate catch of soles, turbot, and gurnard. If they went, said Mr. Neale, they would understand that a boat might shovel ten tons of small unmarketable fish overboard for every five tons which she landed. The last time the writer saw the late Mr. Neale, who was as keenly interested in marine research as any one in the kingdom, he referred bitterly to his belief that his suggestions had been ignored for twelve years. He was convinced of the absolute necessity for continuous investigations in these waters, by scientists on board commercial vessels, to supplement those made on research vessels proper. The latter, he said, clung 'fairly closely to the south and west of Iceland, and made comparatively fow trips, mostly in summer'. It was 'urgently necessary', he thought, 'that investigations should be continuous on the distant fishing grounds', right through the year.

$\mathrm{He}$ died this year without seeing any of these investigations made-or, at any rate, reported; for the only British investigator who was deputed to watch the hake fisheries most unfortumately had himself died before he could publish any of his results.

Mr. Rees, of Swansea, on Hake

'Mushiness' of Hake

Mr. H. E. Rees, of Swansea, who has made careful study of the habits of hake, and whose notes will be useful to British 
naturalists when they find time to consult business men, has noticed a curious condition which attacks the hake particularly in southern waters-and more especially off Cape Ghír. Frequently, if a slit be cut in a fish just above the tail, it is possible by passing the hand firmly down the body from head to tail to squeeze out through this slit practically the whole of the flesh tissues in a semiliquescent form. Such fish must, of course, be distinguished from the ordinary 'soft' hake. All hake become more oily and less 'flaky' and therefore less valuable when they have been gorging on oily fish like mackerel or herring or pilchard. But these Cape Ghír fish are useless for the market.

The condition is known in America as 'mushiness', and a special commission sat under the auspices of the Federal Fisheries Bureau for some time to inquire whether in the case of the Pacific hake it was or was not due to a parasite. The writer has been unable to find the recorded results of this inquiry, but it suggests a useful line of investigation for the Permanent International Council when funds permit of the employment of a fish pathologist.

\section{Miscellaneous Notes by Mr. Rees}

According to Mr. Rees, hake is never caught on the extreme westerly grounds at night ${ }^{1}$; off the north of Scotland and west of Scotland on the South Rona (Gairloch) and on the Dubh Artach grounds, it is caught only at night; whereas on the grounds to the westward of the latter, from Inistrahull north of Malin Head, to the Barra Head grounds, it gets into the trawls both by day and night. Here is an interesting line of inquiry into the effects of depths and temperature and light on the movements of hake, which is not likely to be covered by the hake investigations at present planned by the International Council-and might be overlooked unless the French directors of the researches get into intimate touch with owners in Milford, Fleetwood, Swansea, and Cardiff.

Then it appears that the Galway Bay hake are distinguishable from fish caught on other grounds; they are black, oily, and soft ${ }^{2}$-but not 'mushy' - and do not keep very well. The fishing here off Inishmore-in what the old cartographers used

1 Dr. Bowman writes that in the North Sea the hake feeds principally at night in the upper-water layers, so trawlers fish for it during daylight, when it is at the bottom.

2 Capt. R. Bettess of Fleetwood has observed that hake are always firmer in flesh when caught off rocky ground. West of the Lewis he finds firm 'flaky' fish. In the Minch the few big hake eaught are inclined to be soft. 
to call 'The Bay of Hakes - usually lasts about six weeks, and, with the exception of small haddocks, during these six weeks no other fish are caught. Out to the westward, on the other hand, quantities of bream are caught up to the time the hake set in. But with the arrival of the hake the bream largely disappear. A skipper will often go out to the westward at the beginning of the hake season, and wait there a week or more till the fish come in, so surely can a first-class fisherman anticipate the run. But hake-fishing, like all deep-sea fishing, is a desperate gamble. In January 1921, for instance, a skipper who went out into the Bay of Biscay has just come back to Swansea. He towed 150 miles in the Bay, and caught six hake. 'Monks' (Lophius piscatorius) were, it is true, plentiful. But a voyage of monks is cold comfort to a skipper out for large hake, for monks, though they are in the writer's judgement one of the most delicious of all fishes, will as a rule sell for less than one-third of the price of hake, and are, in Swansea, counted as 'stocker'-the perquisite of the crew.

\section{Mr. M. H. Neale on Hake Fishing}

Mr. M. H. Neale, son of the late Mr. J. J. Neale, of Carditf, has kindly written as follows:

'I have been looking back through our records, and I find the hake-fishing continually changes ${ }^{1}$. Ten years ago at this time of the year (March) we were fishing in the same spots as at present. Hake was being caught from the Westward Ground (about 260 miles from Lundy), and the best trips of hake were obtained from the Bay of Biscay (in the deep water). We have had no trawler fishing the Bay of Biscay this year, but several have landed in Swansea, one yesterday " grossed" $£ 1,400$. Before the war we sent regularly to the Bay of Biscay, and reckoned the best months to be February, March, and April. We have caught quantities there as late as June, but it pays us better to send to nearer grounds before then.'

His ships fish the Porcupine Bank from August to December. Hake is to be found in fair quantities during these months on the edge of the bank. Pollack, ling, bream, and megrims are numerous, and can be caught all the year round. In Galway Bay the hake are to be had in September and October. Here the fish all seem to arrive on one day to spawn. They have roes in them 'well on in September'. 'Below the Bull', i. $\theta$. anywhere between 45 and 110 miles from the Bull rock,

1 Every one is agreed on this point. The hake season off St. Kilda sets in sometimes in June, and sometimes not till the middle of August. Fishermen say that the later it starts, the longer it lasts. 
PLATE IX

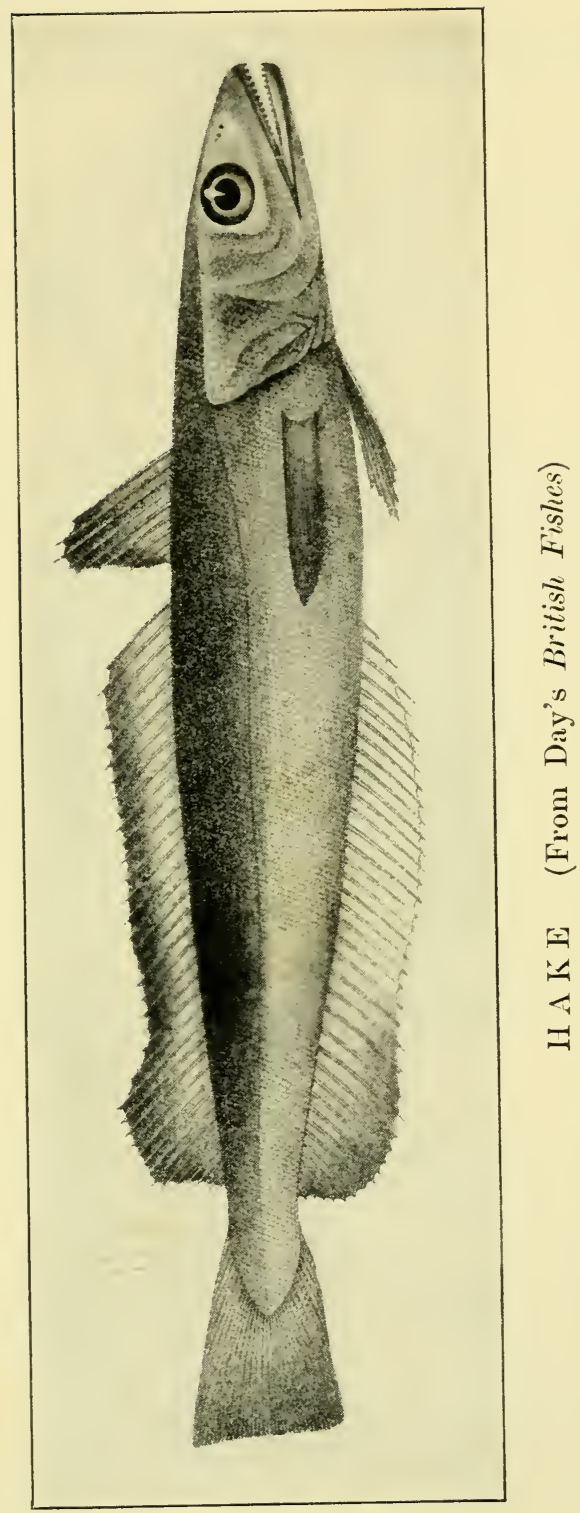



lakie are found off and on throughout the year, the largest catches being landed in May.

He 110 longer fishes off Barra Head, but many years ago his ships used to work these grounds, and landed occasional trips of hake in the winter.

\section{Spawning Period}

Generally speaking, he regards August as 'the chief spawning month, though on many grounds it may be earlier'. His vessels land roes right up to the end of August, but, except in the case of the Galway fish, none from that time till February or March.

\section{General Remarks}

'The hake vary in coloration according to the nature of the ground, some being darker than others. We have caught them in depths of 300 fathoms, which is about the extreme limit of our operations. The hake appears to be a very shy fish, and a large concourse of modern trawlers soon causes them to move from the ground, possibly because many of them are captured. We rarely catch them at night, which, I think, proves that they come up at night to feed on the surface.' Mr. Neale concludes his letter by repeating his father's cordial invitation to accommodate any naturalists who "would like a trip on one of our trawlers. We have one or two very good skippers who are likely to take a keen interest in scientific research.'

Both the older and younger schools of hake catchers, then, take a very real interest in the life-history of the species on which their living depends, and would welcome the opportunity of active collaboration in scientific work. Hitherto they have not even been told about such investigations as have been made.

\section{Postscript}

Capt. R. Bettess of Fleetwood mentions that hake were caught for the first time 20-22 miles north from the Flannan Islands, i. e. about 70 miles north-east by north from St. Kilda, in 1920. They were at 140-150 fathoms; and in 1921 they were again on these grounds. But in 1920 and in 1921 hake were for the first time for 20 years not to be had in paying quantities in the grounds NW $\frac{1}{2} \mathrm{~W}$. from St. Kilda, and along and outside the 100 fathom line in a southerly and westerly direction. The Flannan Island hake are 'the same class of fish' as those caught to the SSW. off St. Kilda. Do they, as Capt. Bettess conjectures, come from grounds still farther north, which have never been triwled? 


\section{CHAPTER XXII}

\section{DR. LE DANOIS ON HAKE}

But now the French Fisheries Department has done what the British Department ought to have done years ago. Under its instructions Dr. Le Danois has collected all the available information about the fish, and especially all such information as a fishing skipper would wish to know, and printed it in clear and simple language-he hardly ever uses the technicalities of his craft-with maps which make his meaning unmistakable. His paper is a model of what these publications should be, and a model of what the fishing industry has for many years demanded (vainly) from British officialdom. It is much too good to be summarized, and the attempt which follows is made with every apology to Dr. Le Danois.

\section{The Spawning of the Hake}

As a general rule the hake seems to prefer a depth of 50 to 100 fathoms for spawning purposes. But Mr. C. Hellyer told the 1908 committee of a ripe specimen which had been caught at 200 fathoms, ${ }^{1}$ and to the south-west of Ireland spawning fish have been caught in water nearly 500 fathoms deep. Le Danois remarks that in this region the slope of the 'continental shelf' is so steep that in the course of a few miles one can get soundings from 100 to 500 fathoms. Possibly, he thinks, the hake spawns here at midwater and not at the bottom. This is, no doubt, a point which his colleagues will soon be enabled to clear up. But farther to the south-where the Continental shelf grows broader opposite to the western mouth of the Channel-and also in the Bay of Biscay hake live in shallower water.

The floating eggs and newly hatched larvae have been found as follows :

\section{Region.}

Season.

Mediterranean, Gulf of Naples

North Spain, $43^{\circ} 23^{\prime}$ N., $2^{\circ} 01^{\prime}$ W. ; $5 \dot{5}$

fathoms.

Bay of Biscay, $47^{\circ} 55^{\prime} \mathrm{N} . \dot{ }^{\circ} 5 \dot{2}^{\prime} \mathrm{W}$.;

27 fathoms
English Channel, $48^{\circ} 40^{\prime} \mathrm{N}$., $50^{\circ} 04^{\prime} \mathrm{W}$.;

60 fathoms

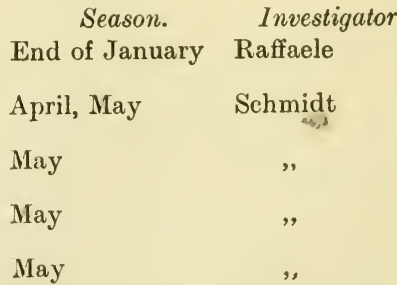

1 ('apt. Bettess has found ripe hake at 250 and 270 fathoms. 
Region.

Season.

Investigator.

South of Ireland, $51^{\circ} 16^{\prime}$ N., $8^{\circ} 10^{\prime}$ W. ; 55 fathoms

North-west of Scotland, $58^{\circ} 4 \dot{2}^{\prime} \mathrm{N}$.,

$6^{\circ} 13^{\prime}$ W. ; 60 fathoms
North of Scotland, $58^{\circ} 44^{\prime}$ N., $3^{\circ} 21^{\prime}$ W.; 62 fathoms

Off Moray Firth .

Skagerrak and Cattegat .

July, September Holt

September

Schmidt

September

July

July, September
,

,

Now by comparing these discoveries of Schmidt and his colleagues with the actual time at which hake are chiefly caught-that is to say :

Off Morocco . . Dec. and Jan.

Mediterranean . . January

Bay of Biscay . . Mar. to Dec.

English Channel . Apr. to June
Mouth of Channel . March to Sept. Southward of Ireland Apr. to Sept. Westward of Ireland May to Sept. ${ }^{1}$ Northward of Scotland .

June to Sept. ${ }^{1}$

Le Danois is able to tell us that hake spawn off Spain and Morocco and in the Mediterranean in winter; in the Bay of Biscay and up our own west coast from spring to autumn. At the westernmost end of the Channel it spawns, Le Danois thinks, for a very short period-chiefly in May. But this hardly accords with the facts that a ripe female was caught by the Oithona outside the Eddystone in July 1913, and that thirteen hake fry ranging from 4.5 to 13 millimetres in length were obtained by Clark off Plymouth this year (1920)-between 31st July and 17th August. So Clark is indubitably right in placing the spawning period in the mouth of the Channel at June to August. It appears to be certain that hake do not spawn, at any rate freely, in the North Sea, and that the eggs found off Moray Firth had been drifted in from the north coast of Scotland.

\section{Sea Temperature and Salinity on the Spawning Grounds}

Right through the whole of their range hake seem to live for choice in water between $48^{\circ} \mathrm{F}$. and $50^{\circ} \mathrm{F}$. in temperature, with a salinity of $35 \cdot 20$ per mille-that is to say, $35 \cdot 20$ pounds of salts (chlorides, sulphates, bromides, and carbonates) dissolved in 1,000 pounds of water. These, at any rate, are the conditions which prevail when the shoals first appear off Moroceo in January, and off the north of Scotland in April, and in all the waters in which the spawners are found in the interim.

1 Le Danois is wrong here; the West of Ireland fishing is mainly from August to December, and the fishing in the Minch is winter fishing. 
Then, in June, Hjort and Le Danois and Hérubel tell us, a submarine current sets in between the Shetlands and Fair Island which carries the warm water from the Atlantic and Mediterranean into and round the outer periphery of the North Sea. A warm current flows down the east coast of Scotland, turns north-east just before reaching the Dogger, and finally sweeps northwards along the edge of the "Norwegian dike'. In this current the hake find themselves at home, and from it they are captured from June to November. Then a cold current from the Norwegian Sea heads back the Atlantic water, the North Sea becomes too cold for hake and they leave ${ }^{1}$-possibly to find the temperature which pleases them in depths as great as 270 or 550 fathoms on the edge of the Continental shelf.

Obviously in tropical seas-except in winter-the hake in its search for the ideal temperature of $48^{\circ}$ to $50^{\circ}$ must avoid the surface. And this accounts for the capture of a specimen at 328 fathoms off the coast of French Guinea by the French research vessels Talisman and Travailleur in 1882.

All this has been put down in detail because the writer has often heard protests among business men at the absorption of scientific men in the 'physico-chemistry' or 'bio-chemistry' of the ocean. 'Why don't they tell us the effect of temperature on hake and how to find them?' That is exactly what scientists are aiming to do. But it has never occurred to Science (till Hjort and Le Danois wrote) to explain to the uninitiated what 'physico-chemistry' meant, or its bearing on the art of catching fish.

\section{Food of Adult Hake}

Le Danois calls the hake 'the Pike of the Sea'. We have seen that it hunts herrings and mackerel and their young. Like the pike, it is an inveterate cannibal, and it seems probable that it continues to feed to some extent right through the spawning season.

As a rule, the grounds which it affects are sandy or gravelly, but on the edge of the Continental shelf it is found in the midst of the 'false corals' or 'soft corals' like Dead Men's Fingers (Alcyonium), which flourish on beds of empty scallop and cockle shells, and among starfish, sea-urchins, and other invertebrates.

\section{The Eggs}

The eggs measure 0.03 inch, ${ }^{2}$ and are provided with an oil

1 January and February and March are months in which practically no hake are found in the North Sea (Bowman).

2 i. c. about 1,140,000 hake eggs are contained in a quart. 
globule. The only recorded laboratory experiment in the hatching of the eggs known to the writer is that of Dr. Raffaele, who fertilized them at Naples in the beginning of May, and hatched them out in sixty to seventy hours. He was, no doubt, using water of considerably higher temperature than prevails on our hake grounds, probably not less than $55^{\circ} \mathrm{F} .{ }^{1}$ and further experiments to determine the rate of incubation at various temperatures are urgently needed.

\section{The Larvae}

The larvae, when they hatch out first, are about 3 millimetres in length. By the time the yolk is absorbed they are said to

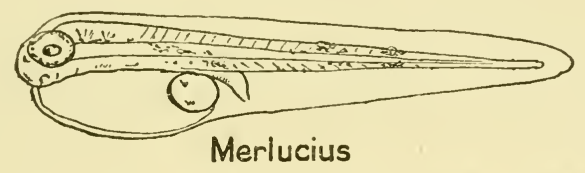

Fia. 9.-Newly hatched hake $\frac{1}{10}$ inch long. (From Meek's Migrations of Fish.)

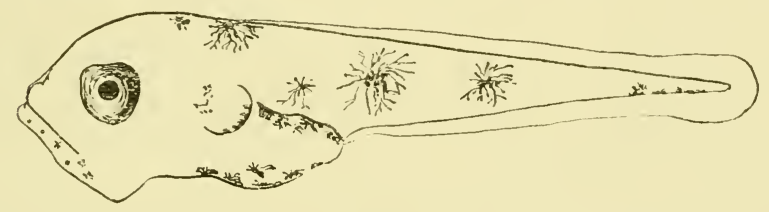

Fra. 10.-Baby hake 0.17 inch (4.5 mm.) long. (Drawn by Dr. M. V. Lebour.)

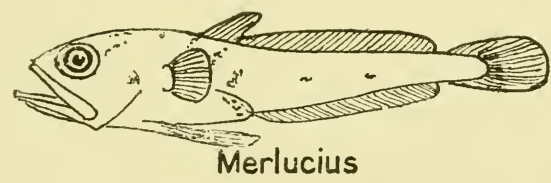

Fig. 11.-Hake fry, $\frac{5}{3}$ inch long. (From Meek's Migrations of Fish.)

measure 4 millimetres. They have been found by Schmidt at 270 to 550 fathoms to the west of our islands, and Clark, between July and September 1920, obtained thirteen specimens ranging from $4.5 \mathrm{~mm}$. to $13 \mathrm{~mm}$.-all except three in about 40 fathoms fifteen miles outside the Eddystone. Dr. Lebour dissected these and found them to be feeding on copepods and their larvae, but there is as yet no information on the allimportant 'baby food' which is eaten before the yolk disappears.

1 The temperature off Provence is $55^{\circ} \mathrm{F}$. at 100 to 150 fathoms. 
The larvae are described by Schmidt as very 'thickset' when they first hatch out, but they gradually get more slender as they grow. Holt has caught young hake under $1 \frac{1}{4}$ inch in length at a depth of 80 fathoms off the south-west coast of Ireland, and this shows that the fry, after drifting at the surface, go to the bottom when they are about an inch long.

The Irish Survey caught fish measuring 6 inches to $7 \frac{1}{2}$ inches in March and May at 40 to 115 fathoms, and ten of 8 inches in May in 53 fathoms. The fry-a few inches long-shown to Hjort off Cape Bojador prove that the species must actually spawn off the Moroccan coast.

\section{Maturity}

The hake is said to be capable of breeding when it is about 8 inches long. Le Danois recognizes that its scales could furnish much useful information as to the age and growth of individual specimens; but this work has not as yet been attempted.

\section{Future Investigations into Hake}

All this means that there is yet much to learn about the life-history of hake, and we have seen that the British fishing industry is greatly concerned that further inquiries should be made. It realizes, with Hjort, that on such knowledge depends 'the life of the industry'.

The International Council in 1920 has decided that the main investigations into the species shall be made by French research vessels, while British research vessels co-operate by collecting for them data as to currents, salinities, temperatures, and the 'small game'. There is every reason to congratulate ourselves that these researches should be in the hands of the countrymen of Le Danois and of Fabre-Domergue and Anthony. No one is better equipped to ' rear' hake fry and discover the all-important mystery of their early feeding, or to read the scales. ${ }^{1}$ It is understood that Portugal and other nations particularly interested in hake-fishing will send naturalists to work on the French research vessels. It is to be hoped that the expeditions will always include at least one British attaché, not only because Great Britain is the pioneer of the deep-sea hake-trawl and the premier hake-fisher of all nations, but because the success of the expedition will obviously be enhanced if the scientists keep close touch-as Hjort has always donewith the skippers of any British trawlers they may be enabled

1 On the assumption that hake scales are 'readable'-a point on which the writer can find no evidence. 
to board. So that a British naturalist might be much less usefully employed than in interpreting on the South-West Banks between British fishermen on the one hand and his French colleagues on the other. Above all, it is to be hoped that the stages in the work will be explained, especially to owners and fishermen in Milford and Swansea and Cardiff and Fleetwood, punctually and clearly step by step as it proceeds, not in the ponderous periods of blue books, but in simple language like that of the pamphlet which the business-like Le Danois has published for business men. 


\title{
CHAPTER XXIII
}

\author{
SKATES AND RAYS
}

The European Catch in 1913 (Analysed)

\begin{tabular}{|c|c|c|c|}
\hline & & Tons. & $£$ \\
\hline England ${ }^{1}$ & . & 17,972 & 253,729 \\
\hline Scotland & . & 6,774 & 35,817 \\
\hline Ireland & . & 345 & 3,426 \\
\hline \multicolumn{2}{|c|}{ Total United Kingdom } & 25,091 & 292,972 \\
\hline Germany & • & 1,204 & 8,718 \\
\hline Holland & . & 1,099 & 12,389 \\
\hline
\end{tabular}

IN 190648 per cent. of the skates came from the North Sea, 26 per cent. from the south-west of the British Isles, 15 per cent. from the north-west of the British Isles, $3 \frac{1}{2}$ per cent. from Iceland, 2 per cent. from France and the Bay of Biscay, and 1 per cent. from Portugal and Morocco. So the family has a wide distribution. It is caught on each side of the $50^{\circ} \mathrm{F}$. line which separates the Northern from the Southern fishes, but is a good deal more common to the south of that line, and off Portugal and Morocco it formed no less than 20 per cent. of the 24,954 tons landed in 1906. The real fact is, of course, that the family of Raiidae-all of whom are classed as skates and rays by the trade-range from cold-water species like the Arctic ray (R. Hyperborea) to hot-water forms.

\section{British Catch (Analysed)}

The following ports landed the greatest quantities :

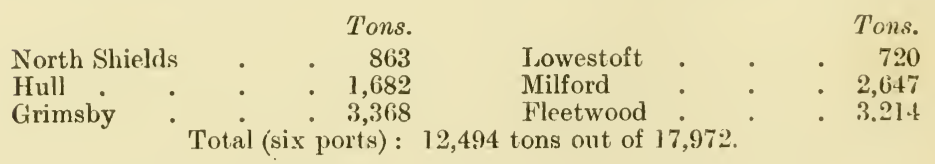

1 In 1920 the landings were:

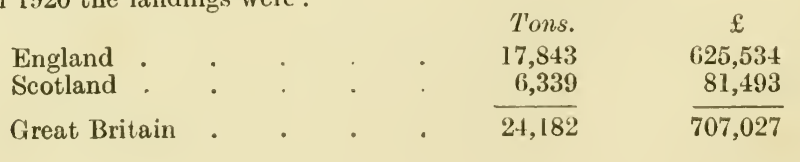




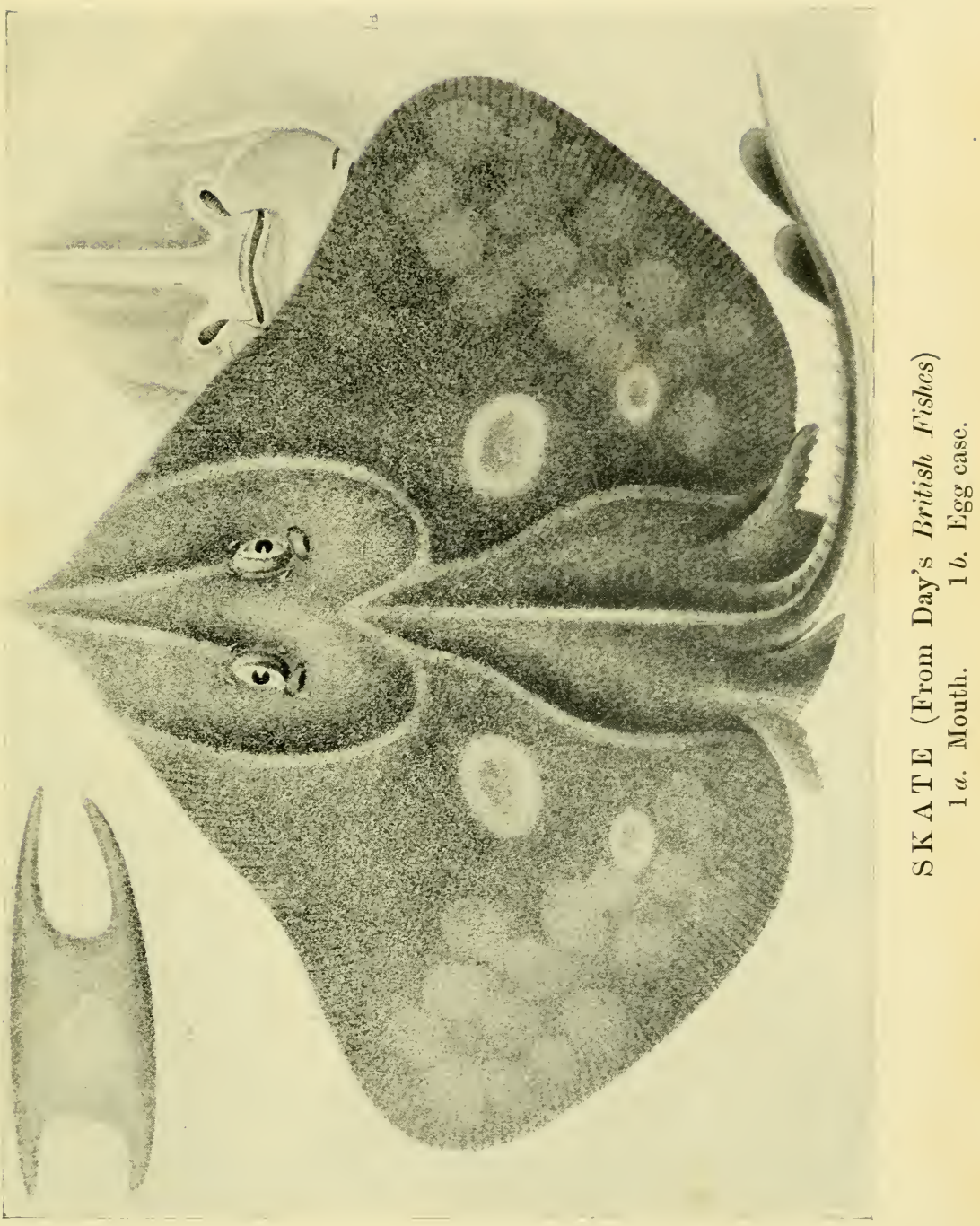





\section{Fluctuations in the Catch}

Landings by first-class vessels on the east coast of England have fluctuated as follows:

\begin{tabular}{|c|c|c|c|c|c|c|c|}
\hline & & $\begin{array}{r}\text { Tons. } \\
\text {. } 4,949 \\
1,180\end{array}$ & $\begin{array}{l}\text { Tons. } \\
4,290 \\
1,092\end{array}$ & $\begin{array}{r}\text { Tons. } \\
3,307 \\
884\end{array}$ & $\begin{array}{l}\text { Tons. } \\
2,956 \\
773\end{array}$ & $\begin{array}{l}\text { Tons. } \\
3,116 \\
1,131\end{array}$ & $\begin{array}{l}\text { Tons. } \\
3,315 \\
1,005\end{array}$ \\
\hline & & & & & & 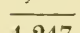 & \\
\hline
\end{tabular}

Minchin ${ }^{3}$ is of opinion that 'the trawls are gradually extirpating the rays, a slow growing and not very prolific tribe'. He has therefore probably information which the writer has been unable to find as to the wanderings, the spawning, and the rate of growth of this interesting family.

\section{Life-History}

But the writer's information about the life-history of the Raiidae is meagre in the extreme. We do not know apparently the factors which make for or against the safe hatching of the eggs in the egg cases, or against or for infant mortality among the young fishes after hatching.

According to Hjort, ${ }^{2}$ about 68 per cent. of the catch comes from waters between 10 and 30 fathoms, and 19 per cent. from 30 to 50 fathoms. But this does not mean that skates and rays do not inhabit great depths. The Arctic ray has never been caught in water shallower than 350 fathoms, and Holt obtained a species named bathyphila at 893 fathoms off Ireland.

Minchin ${ }^{3}$ notes that they usually remain at the bottom, " except during the mating season in early summer, when they rise to the surface to do their courting'. And at this time all species seem to move into shallower from deeper water. In the trade, he tells us, the large kind are generally called 'skate', and lesser ones 'rays', but this rule is by no means universal. Among the inshore varieties he mentions the 'thornback' ( $R$. clavata), known sometimes to fishermen and dealers as 'maids', but more generally under the Dutch name 'roker'. These run to $10 \mathrm{lb}$. in weight, and are 'very common in the eastern part of the Channel, and in all the deeper waters off the Kentish coast and the Thames estuary'. This species is most common in the North Sea and the Kattegat. Hjort has caught them at 60 fathoms on the Faeroe Bank; at 100 fathoms at the 'corner' of the coastal bank south of

\footnotetext{
1 Sea Fishing, p. 84. 2497

${ }^{2}$ Depths of Ocean, p. $457 . \quad$ s Sea Fishing, p. 83. 
$50^{\circ}$ N. ; off Vianna in Portugal on the 22nd April on a hard bottom at 30 to 40 fathoms; and at 150 fathoms on the slope to the south-west of Cape Bojador. In these Moroccan waters Hjort also obtained (in May) White Skate (the largest species caught by our fishermen, which runs to $500 \mathrm{lb}$.), Spotted Ray, Painted Ray, Cuckoo Ray (Raia circularis), and others. And the 'Cuckoo' also turned up with the Thornback in the hauls on the 'south-west banks ', and off Portugal-always in the neighbourhood of the slope.

These species then seem to be 'southern' fishes which wander from the Moroccan banks into the North Sea and northern Atlantic. And there are distinct indications that they, like hake and herrings, regulate the depth at which they swim so as to find the temperatures which suit them. For they inhabit lower levels off Morocco than when they visit northern waters. The 'Great Grey', 'Blue', or 'Common' Skate (Raia batis), and the 'Flappers' (R. macrorynchus) are perhaps more plentiful in northern waters. The latter is a "very common fish in the Irish Sea and the Minch as well as on the southern and western coasts of Ireland' (Minchin). The Michael Sars caught 'Common Skate' on the Faeroe Bank and in the Faeroe-Shetland Channel. But both species are also fairly common in the Mediterranean, where the "thornbacks' are rare. 'The Starry Ray is more common, especially in deep water, than the latter in the North Sea. It is a northern species, and another northern form, the 'Long-nosed Skate', is found only in the extreme north of the North Sea, and in the Norwegian Sea, always in deep water. The Shagreen Ray has been caught by Hjort on the Faeroe Bank, and also off Morocco at nearly 300 fathoms. It appears, generally with the northern Starry Ray, in the North Sea in spring and summer.

Minchin tells us that the largest skate caught inshore "are generally females, and that their teeth are flattened and set close together so as to form a sort of pavement, which enables the skate to crunch up the large shell-fish on which they feed. In the males, on the other hand, the teeth are sharp-pointed and separated.'

\section{The Spawning Period}

According to Johnstone, the rays spawn from May to July ; whether in southern waters the spawning starts earlier is not clearly stated, though it is almost certain. In one respect the family differs from all other commercial food fishes, with the exception of dogfishes. Fach female produces about twenty, eggs only at a time, but G. Sim states that the "Starry Ray' 


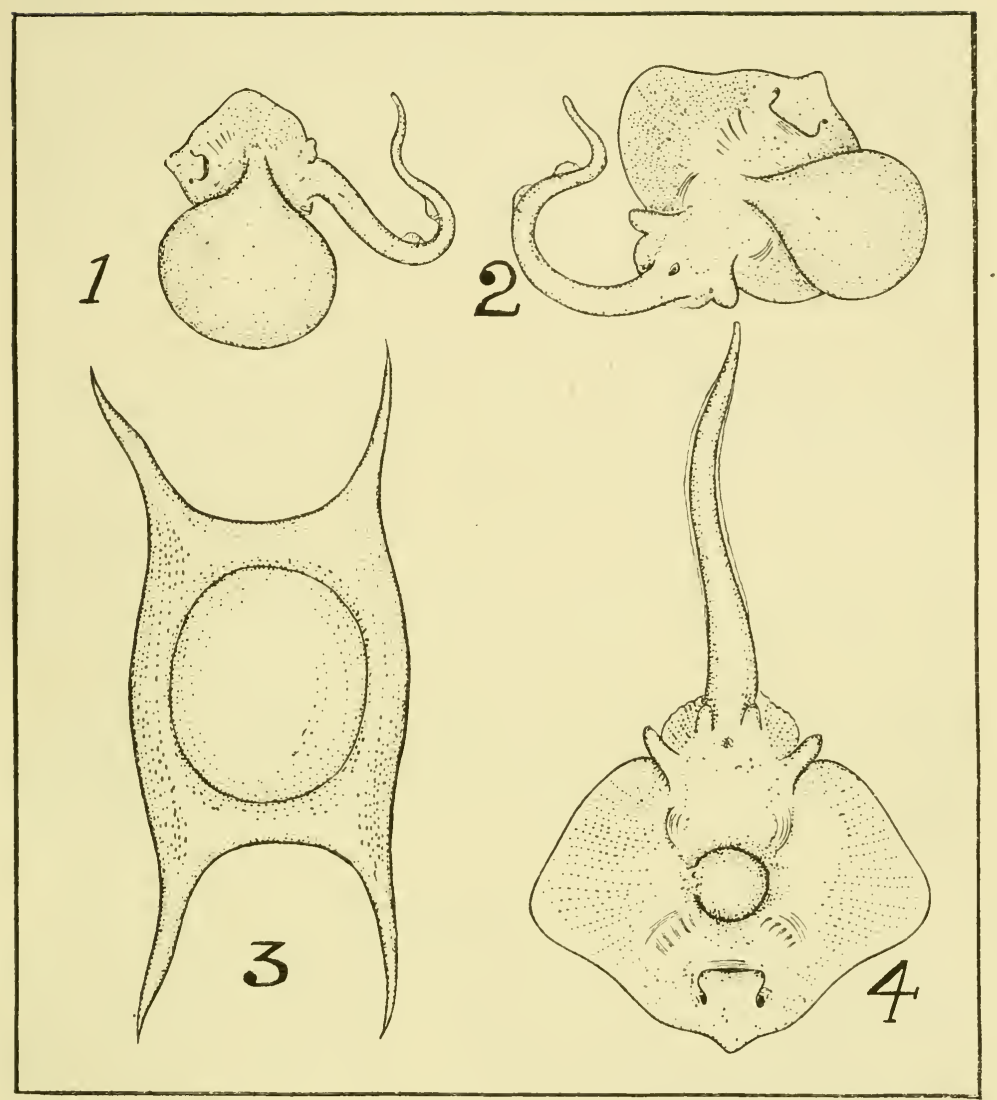

[Drawn by Dr: James Johnstont.

Fig. 12.-DEVELOPMENT OF THE RAY

1 The larra two months before hatching.

2. The same one month before hatching

3. The purse containing the egg.

4 The ray just hatched.

(All slightly reduced.) 
(Raia radiata) (a distinctly northern form which extends to Greenland, Spitzbergen, and the north Russian coast) sheds its eggs all the year round, and Patterson has handled a female 'Cuckoo Ray' on the 4th February 1897 at Yarmouth which was 'full of ova from the size of a hempseed up to chestnuts'. Fertilization takes place inside the body of the female, so there is no loss at this stage. On the other hand, it is not possible to argue that this family is protected by the enormous number of eggs produced, as is so frequently, and perhaps so rashly, assumed in the case of other fishes.

\section{Incubation and Development}

The eggs are protected during the hatching period by the leathery "purses" or egg cases. The writer has no information as to the rate of incubation or subsequent growth, but Meek writes that the young "thornbacks' evidently leave the egg cases in summer, and both the young and adults occur in inshore waters during the summer-the young fish haunting depths as low as 20 fathoms. Minchin may be right in thinking that large shell-fish form the chief diet of the females, and fish that of the males. But the rays and skate are fairly omnivorous. A large common skate was found by Couch $^{1}$ to contain two large plaice, two mackerel, a lobster, an eighteeninch ray, and half a salmon, and another caught at Mevagissey was carrying by way of ballast a stone weighing about one pound.

\section{Future Investigations}

Are skate and rays in fact being 'exterminated'? What are the movements of the northern and southern tribes? How are spawning, hatching, and the survival of the young affected by temperature and other factors? What food do the young require when they first leave the shelter of the egg cases, and what are the circumstances which tell for or against a plentiful supply of this food? At what times of year do the breeding fish congregate chiefly on the various deep-sea grounds from Iceland to Morocco? At what age and size does each species become mature? To what age do they survive? And at what age do they begin to deteriorate as spawners ? All these things may be known, but the writer can find no answers to his questions. The fishing industry has a right (indeed it is its (luty) to demand that the answers should be given or discovered as the case may be.

1 Bickerdyke, Sea Fishing, p. 374 (Badminton Library). 
It is lamentable that we should possess no well-equipped laboratory on the west or north coast of Ireland in which the life-histories of these fishes, and all the great wanderers from the Arctic and from the subtropics, could be worked out in convenient proximity to the grounds which are their meetingplaces. Fortunately the Irish Sea and the Minch are each of them by-roads used by bands of these nomads; and if the laboratories at Piel and Millport could advance no other claim to generous public support, which is very far from being the case, it would still be the duty of the State to equip and man them for the express purpose of filling in the very large gaps which exist in our knowledge of the life-histories of the many tribes of Raiidae. For many of these fish are, pace Dr. Paul Gourret, ${ }^{1}$ among the most delicious and most wholesome of all the fishes which our trawlers catch. Sooner or later the British public, which has for so many years been left in sublime ignorance of the Great Fisheries and their products, will 'discover' skates and rays, and appreciate them at their proper value. Moreover, the skins of some species are easily tanned into a light, durable, and non-porous leather. The exploitation of the Raiidae will almost certainly develop on intensive lines.

It will be lamentable indeed if, when that time comes, naturalists remain unequipped with knowledge of the lives and habits of this widespread and most interesting family. For in that case exploitation is likely to proceed on unsound and un-economic lines.

1 Who thinks that their food value is practically nil (Les Pêcheries et Les Poissons de la Méditerranée, p. 328). 


\section{CHAPTER XXIV}

\section{LING}

The European Catch in 1913 (Analysed)

\begin{tabular}{|c|c|c|c|c|}
\hline Fucland 1 & 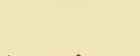 & 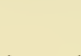 & Tons. & $\stackrel{£}{£}$ \\
\hline Scotland & : & . & 10,820 & 79,554 \\
\hline Ireland & . & . & 360 & 9,809 \\
\hline Total United & 1 Kingdom & . & 21,882 & 198,405 \\
\hline Germany & - & . & 1,594 & 15,879 \\
\hline Holland & . & . & 224 & 2,830 \\
\hline Norway & . & . & 4,078 & 29,497 \\
\hline Blue Ling & . & . & 713 & 3,928 \\
\hline
\end{tabular}

The British Catch (Analysed)

The chief ling ports were:

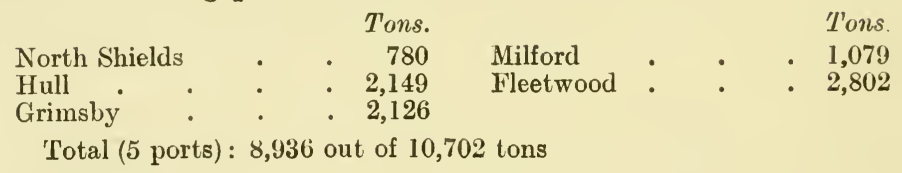

In Scotland :

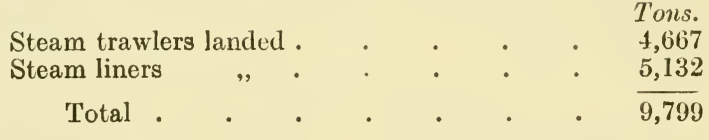

Out of 10,820 tons.

\section{Fluctuations in the Catch}

The catch of ling landed by English steamers on the east coast from the North Sea has varied as follows:

$\begin{array}{llllll}1908 . & 1909 . & 1910 . & 1911 . & 1912 . & 1913 . \\ \text { Tons. } & \text { Tons. } & \text { Tons. } & \text { Tons. } & \text { Tons. } & \text { Tons. } \\ 2,070 & 1,983 & 1,717 & 1,584 & 1,399 & 1,312\end{array}$

The period, of course, forms nothing like a 'cycle' in the life of the sea, and ling are essentially an Atlantic rather than

1 In 1920 the landings were:

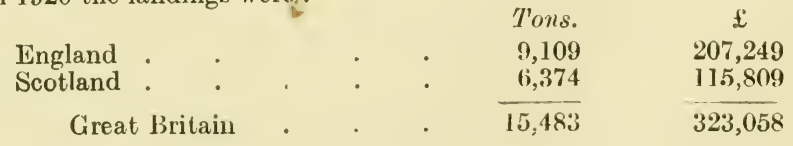


a North Sea fish, so the table would be much more interesting if figures were available for comparison from the Icelandic and Atlantic banks. Still, here is a great ocean migrant, running from 3 to 7 feet in length, showing a steady decline over a period of six years. The writer has nowhere seen statements that ling are being extirpated, but he has heard theories that other fish were rapidly being wiped out which were based on no more convincing evidence than this.

\section{The English Ling Grounds}

There were landed from :

\begin{tabular}{|c|c|c|c|}
\hline & & Tons. & Per cent. \\
\hline Westward of Scotland & & 3,606 & $35 \cdot 30$ \\
\hline North Sea & & 1,695 & $15 \cdot 62$ \\
\hline Southward of Ireland. & & 1,489 & $14 \cdot 58$ \\
\hline Iceland . . & $\bullet$ & 1,361 & $13 \cdot 32$ \\
\hline Rockall & & 536 & $5 \cdot 25$ \\
\hline Faeroe & & 408 & $4 \cdot 00$ \\
\hline West of Ireland. & 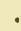 & 394 & $3 \cdot 86$ \\
\hline North of Scotland & • & 356 & $3 \cdot 49$ \\
\hline
\end{tabular}

In the North Sea the distribution of the steamer catch was as follows :

(1) Northern Banks.

(2) SOUTHERn BANks.

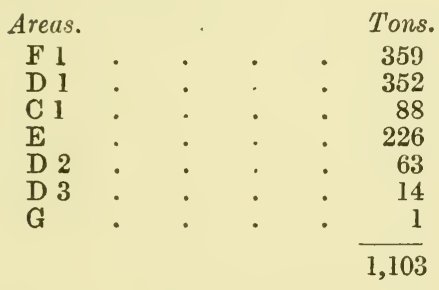

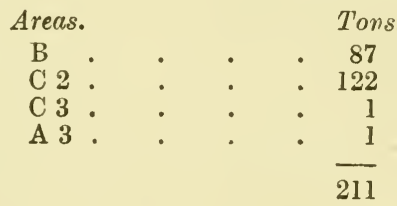

(3) Undisting Uished. 190 tons.

So ling is essentially a 'deep-sea' fish, and 79 per cent. of the catch comes from depths between 30 and 100 fathoms, and one-third or more from between 50 and 100 fathoms.

At still greater ${ }^{1}$ depths-below the 100 -fathom line down to 400 fathoms and over, and all away to the edge of the Continental platform from Spitzbergen and Bear Island along the coasts of Norway, the North Sea plateau, the Faeroe Islands, and along the Faeroe-Iceland ridge, come the 'Blue Ling', which a British research trawler has just found in 1920 on 'Lousy Bank'. In southern waters-right down to Morocco (where Hjort has caught it at 210 fathoms) occurs the 'Southern Ling'. So our market ling have a wide range.

1 Depths of Ocean, p. 457 ; ibid, p. 454. 


\section{Life-History}

Schmidt states that in Iceland the ling are restricted to the south coast, where they spawn at 80 to 130 fathoms in May and June. In the Faeroes and westward of Scotland and Ireland the period ranges from April to August, at depths from

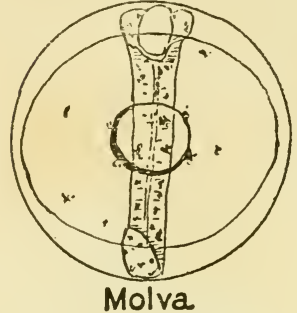

Fıg. 13.-Egg of Ling.

(From Meek's Migrations of Fish.) About 980,000 go to the quart.

about one-ten

Dr. Lebour has caught, at about 26-28 fathoms, ten ling, ranging from 0.18 to 0.5 inches, off Plymouth in July this year, and identified the copepods and water-fleas on which they were feeding. ${ }^{2}$ But the intermediate stages are also known, e. g. the post-larval ling one-third of an inch long figured in pl. XI, fig. 6, of British Marine Food Fishes. At half an inch they have also beon caught at 22 fathoms at the end of August. Up to about 0.8 of an inch the fry are about 15 to 50 fathoms

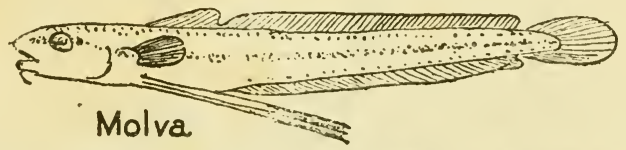

Fre: 14-Ling fry in inch long. (Hrom Meek's Migrations of Fish.)

below the surface-but in mid-water. They get to the bottom when they are about 3 inches long at the end of their first year. 'They do not come inshore till the next summer, when they are about 7 inches long. The writer does not know at what age or size they reach maturity.

Big catches are made in the North Sea from Narch to May; and in December and January very few are cuught.

1 Migrations of Fish, p. 237.

2 Journ. M. B. A., vol. xii, part 2, p. 285. 
PLATE XI

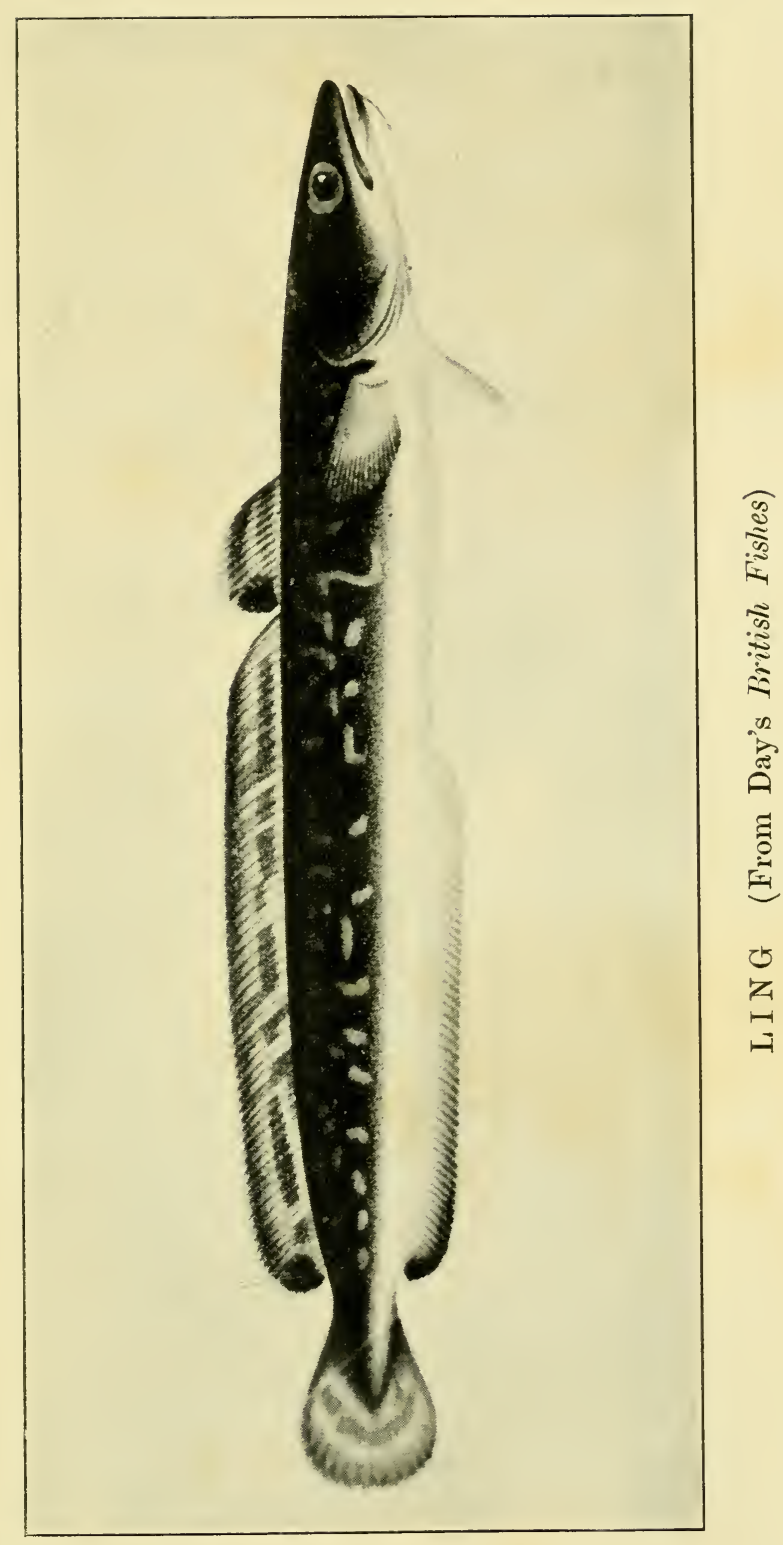



Meek concludes that after spawning they migrate from the North Sea to the Atlantic during the summer, return in the spring, and go back to "deep water in autumn to assemble for the next spawning migration'.

The Blue Ling eggs have never been found; but Schmidt has had fry over great depths off Iceland, the Faeroes, and west of Scotland; he believes that it spawns at 250 to 500 fathoms. The fry are very small- 0.23 to 0.27 inch. But they grow to 3 inches, and are found still floating at the surface at this size. Dannevig has also found fry in the Norwegian fjords.

The Southern Ling fry have been caught by Schmidt near the surface over depths of 500 to 1,000 fathoms south-west of Ireland and in the Bay of Biscay. 


\section{CHAPTER XXV}

\section{WHITING}

\section{The European Catch in 1913}

\begin{tabular}{|c|c|c|c|c|}
\hline & & & Tons. & $£$ \\
\hline England ${ }^{1}$. & - & . & 21,363 & 280,329 \\
\hline Scotland. & • & . & 11,187 & 105,179 \\
\hline Ireland & . & . & 361 & 5,472 \\
\hline Total, United & Kingdom & - & 32,911 & 390,980 \\
\hline Germany & 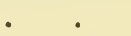 & . & 5,093 & 48,609 \\
\hline Holland (1912) & • & . & 2,408 & 12,836 \\
\hline Norway . & . & . & 627 & 679 \\
\hline
\end{tabular}

\section{The British Catch (Analysed)}

The following ports landed 1,000 tons and over :

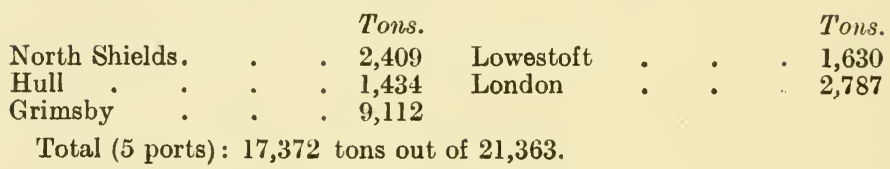

The steam trawler catch was:

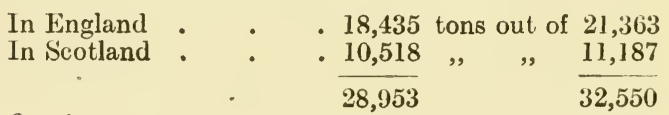

Or 90 per cent.

The main English catch was from the following grounds:

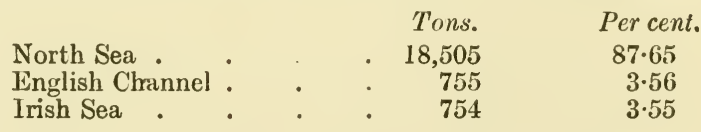

1 In 1920 the landings were :

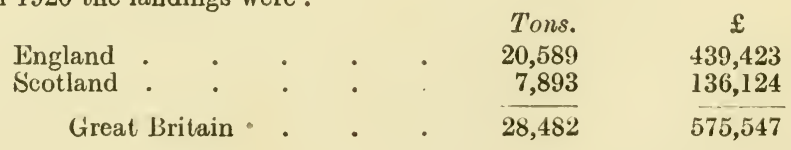


The main distribution in the North Sea was:

\begin{tabular}{|c|c|c|c|c|}
\hline & & & & \\
\hline & Area. & Fathoms & Tons. & Cwts. \\
\hline & (C 2 (East of Dogger) & $20-30$ & 5,542 & $1 \cdot 63$ \\
\hline Southern & B 3 (Brown Ridges, \&c.) & $10-20$ & 1,614 & 1.53 \\
\hline Grounds & B 1 (Dogger Bank) & $10-20$ & 1,541 & $2 \cdot 41$ \\
\hline & B 2 (Leman Bank, \&c.) & $10-20$ & 1,321 & $1 \cdot 24$ \\
\hline Northern & (D 1 (Long Forties, \&c.) & $30-40$ & 1,249 & $1 \cdot 27$ \\
\hline Grounds & F 1 (Witch Grounds, \&c.) & $50-100$ & 2,857 & $4 \cdot 01$ \\
\hline
\end{tabular}

Hjort estimates that 29.2 per cent. of the whiting in the North Sea are caught at 10 to 20 fathoms, ${ }^{1}$ and $40 \cdot 3$ per cent. at 20 to 30 fathoms. He caught whiting in April 1910 as far south as Vianna in Portugal on a bank at 30 to 40 fathoms in company with soles, large hake, and skate.

\section{Fluctuations in the Catch}

The landings from the North Sea by first-class English vessels on the east coast has varied as follows:

\begin{tabular}{|c|c|c|c|c|c|c|c|}
\hline \multirow{3}{*}{$\begin{array}{l}\text { Steam trawlers } \\
\text { Sailing vessels }\end{array}$} & & $\begin{array}{l}1908 . \\
\text { Tons. }\end{array}$ & 1909. & 1910. & $\begin{array}{l}1911 . \\
\text { Tons. }\end{array}$ & $\begin{array}{l}1912 . \\
\text { Tons. }\end{array}$ & 1913. \\
\hline & & $\begin{array}{l}9,744 \\
1,389\end{array}$ & $\begin{array}{r}10,595 \\
1,494\end{array}$ & $\begin{array}{r}11,870 \\
1,321\end{array}$ & $\begin{array}{r}10,330 \\
1,422\end{array}$ & $\begin{array}{r}14,820 \\
1,953\end{array}$ & 16,707 \\
\hline & & 11,133 & 12,089 & $\overline{12,191}$ & 11,752 & 16,773 & $18, \overline{482}$ \\
\hline
\end{tabular}

So the commercial statistics, so far as they go, give no indication at all that the species was being 'fished out' before the war, although it was presumably subject to the same intensity of fishing as plaice, haddock, and other species which have caused anxiety. It spawns for choice at depths between 10 and 30 fathoms, ${ }^{2}$ that is to say in shallower waters than the cod or the haddock, and sometimes in water shallower than the plaice. Are whiting, in fact, less subject to infant mortality than other species? And what is the reason? Unfortunately the gaps in our knowledge of their life-history are so considerable that these questions cannot be answered.

\section{Life-History}

\section{The Spawning Grounds}

When McIntosh and Masterman wrote their British Marine Food Fishes the spawning grounds had not been exactly located. Meek now gives them as being located north and west of Britain, in the Irish Sea, English Channel, Bay of Biscay, southward of 
Ireland, the North Sea, and the Norwegian sea as far north as I'rondhjem, at depths between 20 and 25 fathoms. It may be taken that Hjort is right in giving the optimum spawning depth as 10 to 30 fathoms. Storrow has made an admirable series of drawings depicting the egg at all stages, which is reproduced on p. 214 of Migrations of Fish.

\section{The Spawning Period}

Clark states that whiting spawn from February to September, and that there is a large production of fry in the Plymouth area. Meek gives the spawning time as February to June.

\section{Incubation}

McIntosh and Masterman hatched out the $\operatorname{eggs}^{1}$ (in April) on the tenth day at a temperature which is not stated in their book. The writer can find no record of any hatching table designed to show the effect of warmer or colder water on the time taken in the process.

\section{The Larvae and Fry}

On hatching, the larvae measure $(3 \cdot 2-3 \cdot 5$ millimetres) just over one-tenth of an inch. They appear to 'swim about actively in the surface water', which may mean that they are able to look after themselves very early in life. While in this stage they drift all over the North Sea, the Channel, and the Irish coast, also along the south and west coasts of Iceland and the Faeroes, and along the Norwegian coast. They are believed by some people, including Sars, to shelter themselves under jelly-fish when floating at the surface. As they reach the shallows near the 50-fathom line they take to the sea-bed, and continue their journey towards the coast. In winter they retreat into rather deeper water.

\section{Subsequent Development}

The most interesting and most recent observations on young whiting are those of Clark and Dr. Lebour ${ }^{2}$ at Plymouth in 1920, and Storrow at Cullercoats has done characteristically excellent work on the earlier stages. Two days after hatching, his young whiting were 3.9 millimetres long. ${ }^{3}$ The writer has found no record of attempts to feed whiting in this early stage before the yolk is absorbed, and this leaves a lacuna in our knowledge of its life-history in the most important and most

1 The eggs average 0.047 inch $=651,000$ to the quart.

2 Journ. M. B. A., N. S. XII, No. 2, p. 182, and pp. 279-82.

${ }^{3}$, Migrations of Fish, p. 218. 


\section{PLATE XII}
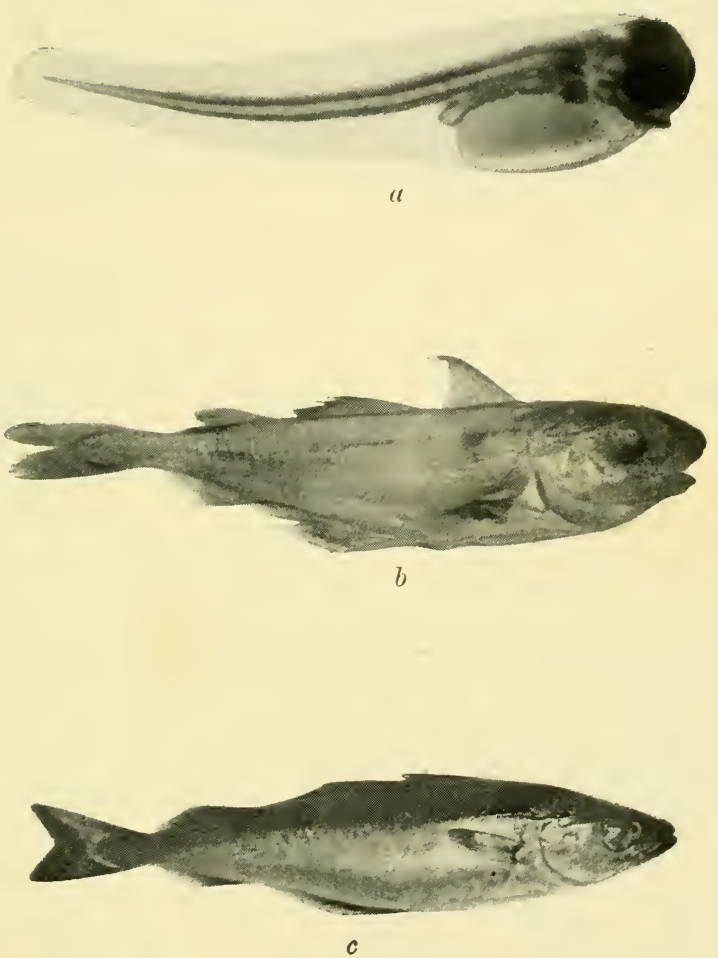

YOUNG FISH (Meek)

a. Whiting two days after hatching, about $0.15 \mathrm{in}$.

b. Haddock $4 \frac{2}{5}$ in. end of first September after hatching (Ch. XV).

c. Coalfish just under 6 in. middle of first October after hatching. 

interesting period. The young fish found at Plymouth this year ran as small as 5 millimetres both in July and August, and at this size they contained no perceptible food. This may mean, as in the case of the lemon sole, that the babies first supplement the yolk with single-celled organisms which they digest very quickly. At 6 millimetres they were eating the copepods and their larvae. Experiments have shown that at this stage till they are 9 millimetres long they prefer the copepod Pseudocalanus to all other food, but as this species is not very abundant in early summer they take Acartia and Calanus as a pis aller. Temora, on the other hand, which is the favourite food of soles and dabs, is hardly ever touched by baby whiting. These Plymouth fry in July and August were some of them as . much as 22 millimetres, or $0 \cdot 8$ inch long. At this stage they

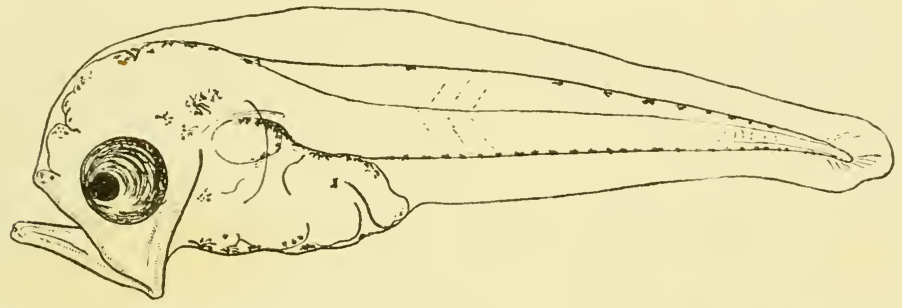

Fig 15.-Baby whiting 0 $16(4 \cdot 3 \mathrm{~mm}$.) long. (Drawn by Miss M. V. Lebour.)

begin to eat young fish-some of them half their own size! By September the whiting hatched in March were 2.5 to 3.3 inches in length. They therefore, as was natural in captivity, grew rather more slowly than the rate calculated roughly by Fulton ${ }^{1}$ in 1889, who stated it thus for young whiting at large in the North Sea :

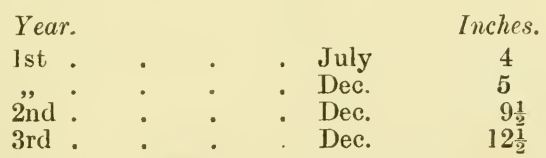

Fulton also found that whiting were mature at 9 inches-that is to say (sometimes) in their second winter.

Hjort caught young whiting (size not stated) at 20 fathoms on the north slope of the Dogger, temperature $50^{\circ} \mathrm{F}$. Their stomachs seemed to contain sand only, but on examination it was found that mixed with the sand were quantities of minute

Rep. F. B. S, p. 157. 
sand hoppers (amphipods), which formed their principal nourishment. Hjort points out that these small crustaceans are extremely numerous in some places on the sea-bottom, and entirely absent in others of the same depth and temperature. Their presence or absence must therefore depend on the currents at the bottom ${ }^{1}$; and on their presence or absence will depend whether fishermen do or do not find shoals of young fish on these grounds. Here is a good instance of the direct connexion between research into the microscopic life of the sea and commercial fishing, which, to the best of the writer's belief, has never been explained to fishermen.

1 Hence one good reason for measuring bottom currents with 'bottom trailers'. 


\section{CHAPTER XXVI}

\section{LEMON SOLES}

The 1913 Catch (Analysed)

\begin{tabular}{|c|c|c|c|c|c|c|}
\hline $\begin{array}{l}\text { England and } \\
\text { Scotland }\end{array}$ & Wales ${ }^{1}$ & 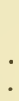 & & . & $\begin{array}{l}\text { Tons. } \\
2,976 \\
1,834\end{array}$ & $\begin{array}{c}\mathfrak{£} \\
162,440 \\
83,472\end{array}$ \\
\hline Total U.K. & . & . & • & & 4,810 & $\overline{245,912}$ \\
\hline $\begin{array}{l}\text { Netherlands } \\
\text { Germany }\end{array}$ & . & : & . & : & $\begin{array}{r}56 \\
1.808\end{array}$ & $\begin{array}{r}2,261 \\
52,741\end{array}$ \\
\hline
\end{tabular}

Figures for other countries are not available, but Dr. Kyle's statistics, published for the International Bureau, in 1906 gave the European catch at 4,432 tons metric, of which $77 \cdot 5$ per cent. came from the North Sea, 8.9 per cent. from Faeroe, 6.4 per cent. from Iceland, $5 \cdot 2$ per cent. from south-west of the British Isles, and 2.0 per cent. from north-west of the British Isles. It follows that the species is essentially a product of the British fishingfleet.

\section{British Catch (Analysed)}

It is also, in the main, a deep-sea product. Steam-trawlers landed in England 2,523 tons, while in Scotland the whole eatch except 28 tons came from trawlers. The landings were as follows from grounds producing more than 20 tons :

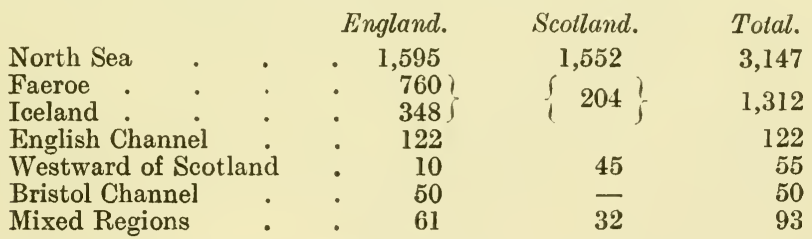

The big English vessels landed 762 tons from the southern and 759 tons from the northern portion of the North Sea, and as the latter grounds are those chiefly frequented by Scottish trawlers it is clear that the lemon sole is caught principally to

${ }^{1}$ In 1920 the landings were :

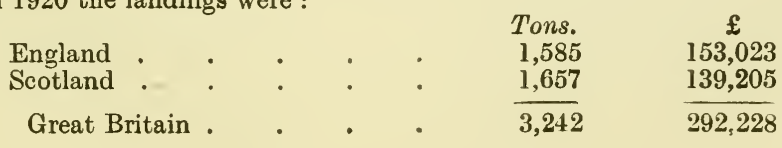


the northward of the Tees-Skaw line. The most prolific areas seem to be the D 1 area between the 30 and 40 -fathom lines to the north-west of the Dogger all along the coast up to the 'Long Forties', and the B 1 area, which includes the Leman, Swarte, and Well Banks, and other grounds from 10 to 20 fathoms between the base of the Dogger and the English coast.

The following are the chief ports landing lemon soles in England :

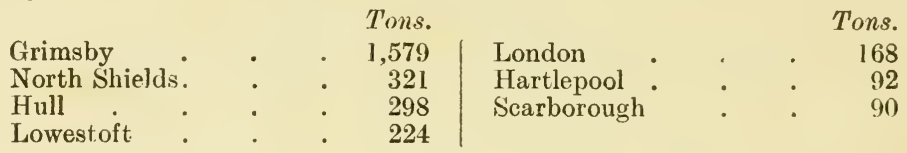

Total ( 7 ports) : 2,772 out of 2,976 tons.

The true lemon sole (Pleuronectes microcephalus) is easily distinguishable from all other flat-fish by the very small head which gives it its specific name. Unfortunately, the species is also known locally as Lemon Dab, Smear Dab, Merry Sole, Smooth Dab, and Sand Fluke; and other species like the Long Rough Dab (Hippoglossoides limandoides) and the French Sole are sometimes retailed as 'lemon soles'. Thus confusion arises.

Hjort tells us that 32 per cent. of the fish landed come from between the 30 and 40 -fathom line, 31 per cent. from between 10 and 20 fathoms, 18 per cent. from between 20 and 30 fathoms, and 12 per cent. from between 40 and 50 fathoms. And he classifies it along with turbot, young halibut, hake, gurnards, and monks as an inhabitant of the medium depths. ${ }^{1}$ Hérubel gives its habitat as the 'Deep Banks', and its distribution as North Sea (Great Fisher Bank, Shetlands), Atlantic.

Meek gives the distribution as follows: 'North-east Atlantic, Murman Sea, and Iceland to the Bay of Biscay, extending into the Skagerrak. Common in the north-west part of the North Sea, west of the British Isles, at the Faeroes, and Iceland (20-100 fathoms).'

\section{Life-History}

\section{The Spawning Period and Grounds}

Clark says that the lemon sole spawns from February to . July off Plymouth ; Meek, from May to September in the North Sea ; Hérubel from April to July. Clark notes that he catches the baby fish while they are still at the surface off Plymouth, "later than any of the other species of Plenronectes. This 


\section{PI. A TE XIII}

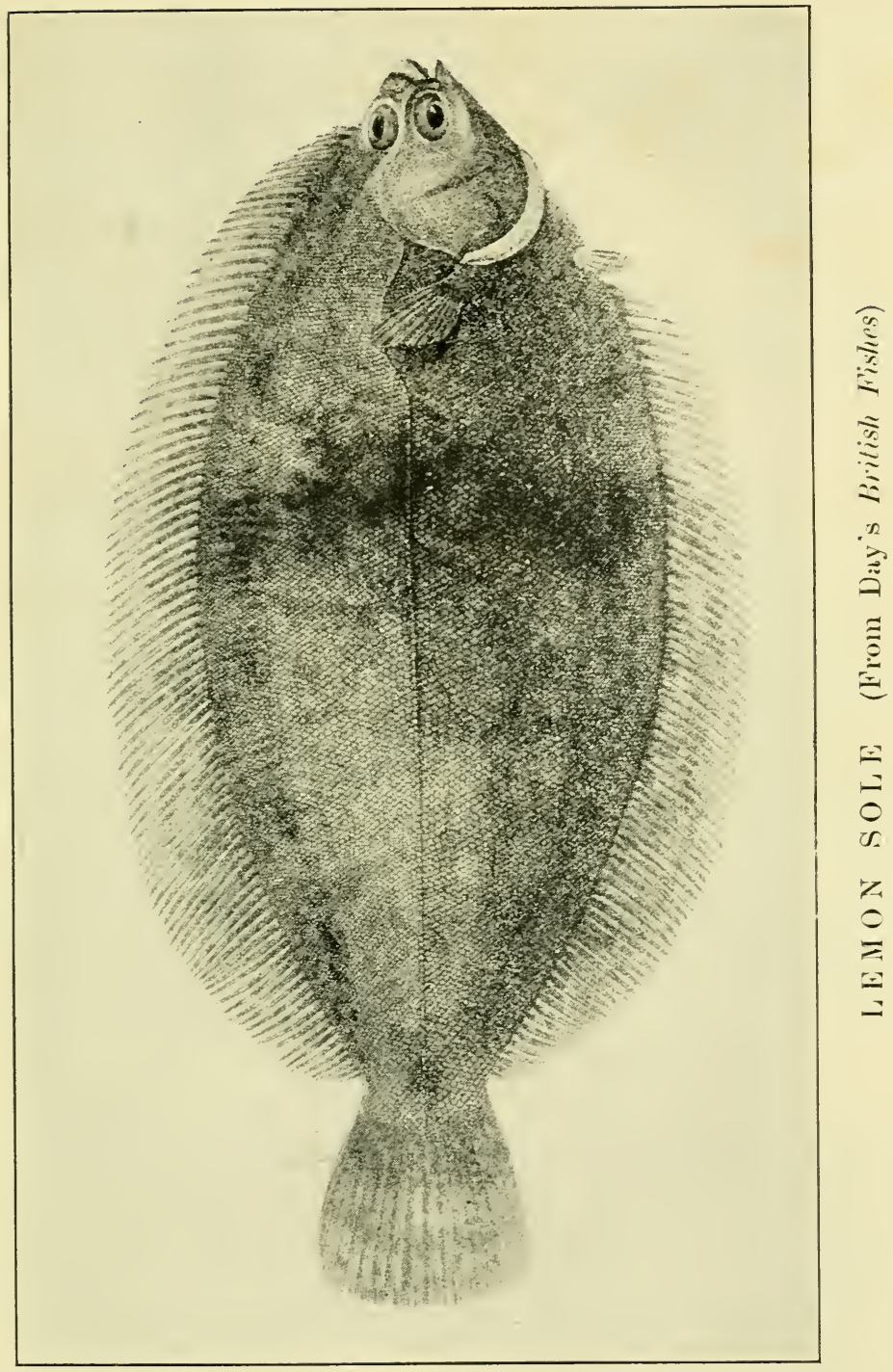



is due, not to a later spawning period, but to a longer pelagic ${ }^{1}$ life. The species is a deep-water form, and the main spawning probably takes place well off shore.' It is evident that the fish is ripe very much earlier in southern waters than farther to the north. Cunningham found eggs floating at the surface at Plymouth in March, April, and May; Holt got them off the west coast of Ireland in April, May, anc June. Ripe fish are to be had, according to McIntosh, off the east coast of Scotland from April to August ; and Ehrenbaum says that off Heligoland the spawning is at its height in the latter half of June and in July. ${ }^{2}$ Meek summarizes the spawning grounds as occurring west of Ireland and Scotland, and in the deeper parts of the middle and northern North Sea, and the Skagerrak; the main grounds being in the north-east of the North Sea, and one off the coast of Fife.

\section{The Eggs and Incubation}

The eggs, which measure about $0.05^{3}$ inch in diameter, are smaller than those of the plaice. As with so many species, no exact table has been worked out, or at any rate published in English, to show how the rate of incubation varies with variations in the temperature of the water. This means that there is plenty of work to be done on the life-history of the lemon sole. All that is cetain is that the hatching takes place more quickly in warm water. Cunningham, for instance, fertilized eggs in April at Plymouth which hatched on the seventh or eighth day. McIntosh's eggs at St. Andrews were fertilized at 8 p.m. on the 8th July, and hatched-some on the sixth, some on the seventh day. It is hardly possible to lay too much stress on the very urgent need for further experiment with fairly large numbers of eggs, and especially in the case of lemon soles at St. Andrews and Cullercoats, in order to arrive at a really reliable 'hatching table ', for all commercial species of fishes.

\section{The Larvae}

On hatching out, the larvae measure $0 \cdot 13$ inch to 0.17 inch $(3.5$ to $4.5 \mathrm{~mm}$.). Their outstanding characteristic is hardiness. McIntosh tells us they are so hardy " that a number lived about six days in a small glass cell 2 inches by $\frac{1}{2}$ inch deep, the water being filled up as it evaporated'. That is, as fish culturists know, about as severe a test as any baby fish could be called

1 i. e. to the fact that they float at the surface longer than other flat fishes [see p. 147 (footnote)].

2 British Marine Food Fishes, p 366.

3 About 455,000 to the quart.

2497 
upon to undergo! 'Little difficulty', says MeIntosh, ' would be encountered in hatching and rearing it under artificial circumstances.' The rate of development, no doubt, like the rate of incubation, varies with temperature, and again we are without very badly needed data; but in the case of the fish described by McIntosh, which were in water of a temperature not recorded, the yolk had much diminished on the third day. On the fourth day the mouth was gaping without any movement of the jaws. Neither McIntosh nor Meek tells us how many days passed before the complete absorption of the yolk, but the latter writes that at that time the larvae measure about $0 \cdot 21$ inch $(5.5 \mathrm{~mm}$.).

\section{The Post Larval Fry}

Cunningham's fry lived to the eleventh day. There is no record of any attempt to feed them before the absorption of the sac, and no information as to what constitute favourable or

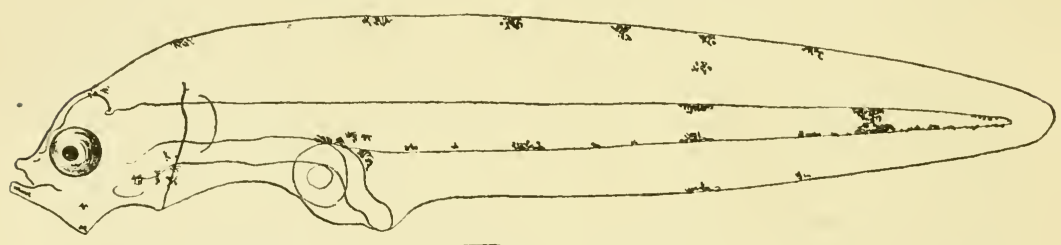

Fia. 16.-Baby lemon sole 0.25 inch $(6.5 \mathrm{~mm}$.) long. (Drawn by Dr. M. V Lebour.)

unfavourable circumstances during this all-important critical period. Clark this year obtained at Plymouth nineteen little lemon soles, varying from 6 to 18 millimetres in length. All these were still floating at the surface. Dr. Lebour dissected nine little fish; the smallest of these was 7 millimetres long and had been feeding on the eggs of some copepod; two of 8 millimetres contained no perceptible food. At 9 millimetres they were feeding on the free-swimming larva of the copepod Temora, and up to 19 millimetres no food was found in them except the eggs and larvae of copepods. Her previous records 'show many specimens with no food, and what there is consists chiefly of very small crustacea and unicellular organisms. It seems evident that Pleuronectes microcephalus is incapable of eating any large copepods, and that its diet up to the time of metamorphosis consists of very small organisms, its food being more like that of the flounder than of the dab and soles.' 1 The newly-hatched flounder is more or less of a vegetarian.

' Journ. M. B. A., N. S. xii, No. 2, p. 294. 


\section{Fluctuations in the Catch}

At this point a digression is indicated. The catch of lemon soles landed on the east coast by steam trawlers from the North Sea has risen steadily from 1,037 tons in 1909 to 1,280 tons in 1913. This is an extremely short period to regard as a cycle, and the curve may indicate only that the lemon-sole grounds were more intensively exploited, but from Table VIII of the Annual Sea Fisheries Report for 1913 it appears that the lemon sole is the only steam-trawl fish of which the catch steadily grew in this manner. The writer would inquire whether there are grounds for believing that the lemon-sole population of the North Sea was, in the five years before the war, really growing. Whether the fact that the lemon-sole statistics for this period give an upward curve quite distinct from the curve of every other species of fish can be connected with the fact that its diet in the earliest larval stage differs from the diet of its congeners, soles and plaice and dabs? Are lemon soles less subject to infant mortality than other fish? Is this because its baby food is a more stable quantity on its nursery grounds than that of other fishes? Is it because it does not (like its larger-mouthed cousins) require any food other than the contents of its yolk-sac?

\section{Further Development}

It will be noted that none of the Plymouth specimens this year had taken to the bottom, and none, of course, had turned into flat fishes. They were swimming at the surface ' edge up' even when they were 19 millimetres ${ }^{1}$ (over three-fifths of an inch) in length. Petersen has obtained in November a specimen $1 \cdot 6$ inches long, which was actually at the bottom in the Ska. gerrak. Neek tells us that the fish begins to turn over on to its right side and swim as a flat fish not before it is about 1 inch long; even the early hatched larvae do not go to the bottom till late in the year, and they always go to the bottom in fairly deep water. The fish hatched late in summer pass the first winter drifting at the surface. Some of the young fish float down the coast of Scotland with the current, and have been found in the Humber by Holt in October and November at $2 \frac{1}{2}-3 \frac{1}{2}$ inches. These fish were believed to have been hatched in the previous year. Williamson in 1893 drew up a complete table of sizes of lemon soles from ( $9 \cdot 7$ millimetres) $0 \cdot 3$ inch to 10 inches long, and concluded that in the North Sea the fish took severa] years to reach the latter size.

1 i. e. in length. Plaice turn into flat fish when they are about 45 days old and about (— $15 \mathrm{~mm}$. long [see p. 36]. Lemon soles float longer than plaice at the surface, i. e. they have what is called a longer 'pelagic existence'. 


\section{$M r$. Storrow on Lemon Soles}

Mr. Storrow, of Cullercoats, in 1916 wrote some valuable notes on the growth of lemon soles. He found, from examining eight fish, that it was not easy to age them from the marks on the ear-stones, which were not nearly so clear as those on the ear-stones of dabs or plaice. His photographs of the seales of two of these fish, however, show that they indicate the age distinctly enough. The photograph does not very clearly

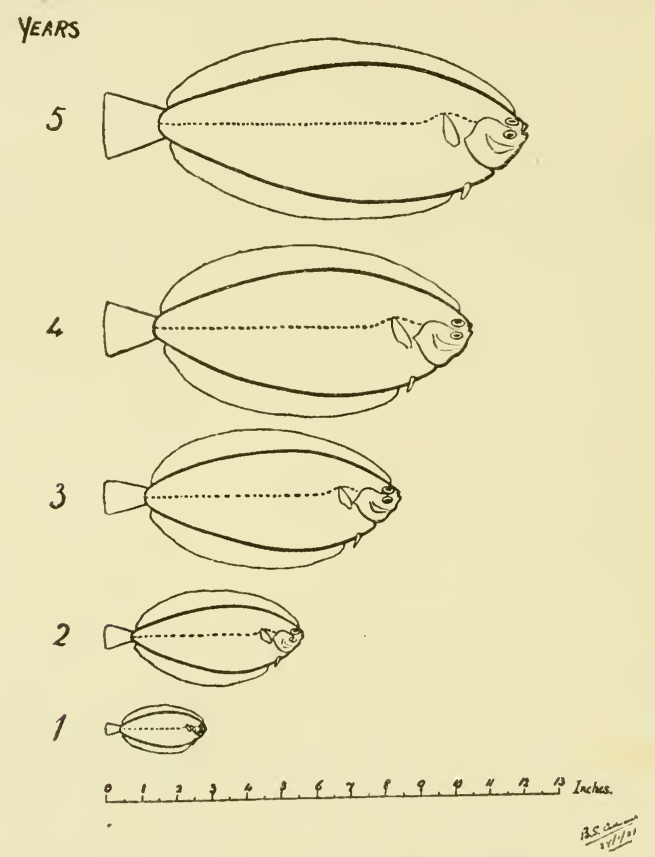

FIG 17.-Lemon soles (After Storrow.)

indicate the end of the eight-years' growth in the case of the older fish, but ' it is clear enough under the microscope '.

The growth is rapid at the beginning of summer, and slows down until the concentric rings come very close together. It was found that practically all the scales (out of 140 each examined from two lemon soles) gave similar readings as to the age of the specimen from which they were taken, though in a few scales the ridges were absent round the central focus. This seems to establish the utility of scale reading as applied to the species.

1 Dore Marine Laboratory Report, N. S., V, T. 58. 


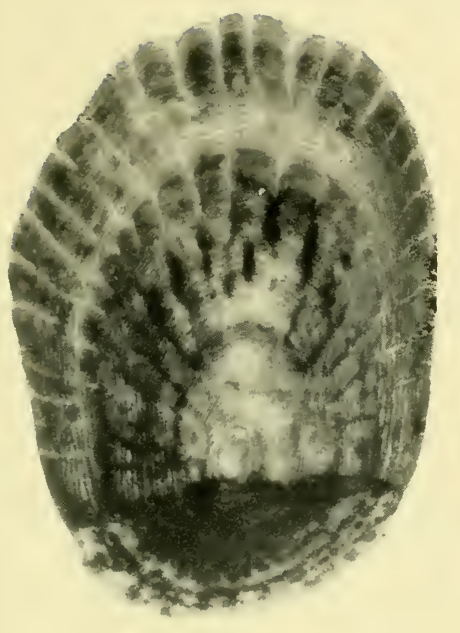

A

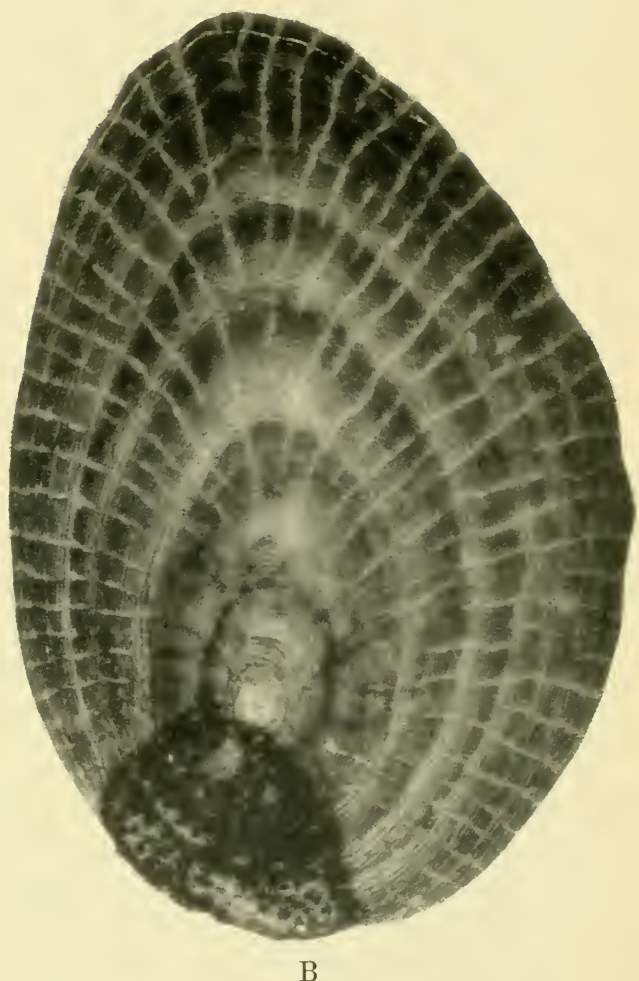

SCA LES OF L EMON SOLES, caught in April 1916

(A) from fish 9 in. long, fourth summer's growth just beginning.

(B) from fish 16 in. long, ninth summer's growth just starting.

(Photograph by B. Storrow.) 

Following on this, Storrow obtained the scales from the remains of fifty-six lemon soles which had been filleted. These he examined with the following result :

\section{Inches. Inches.}

Fish, 4 years old, ranging from $9 \cdot 8$ to $12 \cdot 2$ averaged $10 \cdot 2$

\begin{tabular}{|c|c|c|c|c|c|c|c|}
\hline & & & & & & & \\
\hline 5 & ," & , & , & $9 \cdot 8$ & $15 \cdot 3$ & ," & $12 \cdot 2$ \\
\hline 6 & ," & ,, & ,, & $12 \cdot 5$, & $15 \cdot 4$ & ," & 13 \\
\hline 7 & , & , & ," & 11.8, & 15 & ,", & $13 \cdot 4$ \\
\hline 8 & , & , & , & $13 \cdot 3$ & $15 \cdot 9$ & ," & $14 \cdot 2$ \\
\hline 9 . & $\mathrm{r}-\mathrm{ol}$ & fish & reraged & & & • & $15 \cdot 3$ \\
\hline 10 & , & ,, & , & • & • & . & 15 \\
\hline 11 & , & , & ", & • & . & . & $6 \cdot 1$ \\
\hline 12 & ," & , & ., & • & 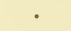 & . & $15 \cdot 6$ \\
\hline 13 & , & , & ," & - & - & . & $6 \cdot 2$ \\
\hline 14 & , & ," & , & . & . & . & $16 \cdot 0$ \\
\hline 16 & ," & ," & , & . & . & . & 16 \\
\hline
\end{tabular}

Here is quite a wealth of information ${ }^{1}$ obtained by a naturalist from the waste portion of lemon soles. It cost him practically nothing. It was available because he was working in close proximity to a fishing-port, and in that intimate co-operation with fish-catchers which is the tradition of his laboratory. $\mathrm{He}$ was able further from this material to calculate that the average growth in the first three years would have been :

\section{1 year old from $1 \cdot 6$ inches to $4 \cdot 3$ \\ 2 years old from $3 \cdot 1$ inches to $7 \cdot 9$ \\ 3 years old from $5 \cdot 9$ inches to $11 \cdot 8$}

All this bears out Williamson's observations as to the slow rate of growth. But one great lesson of scale reading is that size is not a reliable index to the age of a fish. A 15-inch lemon sole, for instance, may be anything from five to twelve years old. The smallest ripe female caught by Holt was 8 inches long. She may have been two or three years old. The smallest ripe male caught by Cunningham was $6 \cdot 4$ inches long, and was probably also two or three years old. But no conclusions as to the hatching, growth, maturity, spawning, and senescence of fishes will be really reliable unless they are based on systematic scale reading; and scales can be read only by the aid of the microscope. Storrow's material was obviously enough very limited. There seems to be no reason at all why work on these lines should not be carried out on a really big scale every year. The work is cheap. It is not particularly attractive. It does not involve expenditure on steamers, or even on sea-going fish-measurers. But, extended and systematized, it might in

1 Does the table not indicate that it is advisable to kill off as many as possible of the fish over nine years old-the age at which they begin to 'go back'? 
the end provide data which would go far towards solving the problem of fluctuations in the catch, when some one finds time and opportunity to correlate with it observations on the food of baby lemon-soles on the lines of Dr. Lebour's work.

\section{Future Investigations}

The lemon sole is a valuable fish; at Christmas 1920 it was fetching at Billingsgate twelve to fourteen shillings a stone, when turbot was selling at eight to eleven shillings, halibut at sixteen to twenty shillings, and soles at eleven to fifteen shillings. It is therefore a species in which all persons who fish the northern and southern portions of the North Sea are necessarily interested.

The very wide gaps in our knowledge of its life-history have been indicated; the main problem appears to be, "Why have lemon soles not ever been suspected of being " fished out", while so many other kinds of fish have (rightly or wrongly) thus been suspected ?' The working out of the answer entails researches into the effect of many factors on its hatching and early development. They will be of interest not only in themselves, but (probably) as checks upon deductions made from analogous or contrasted factors in the lives of other fishes. 


\section{CHAPTER XXVII \\ THE HERRING FISHERIES}

The European Catch, 1913

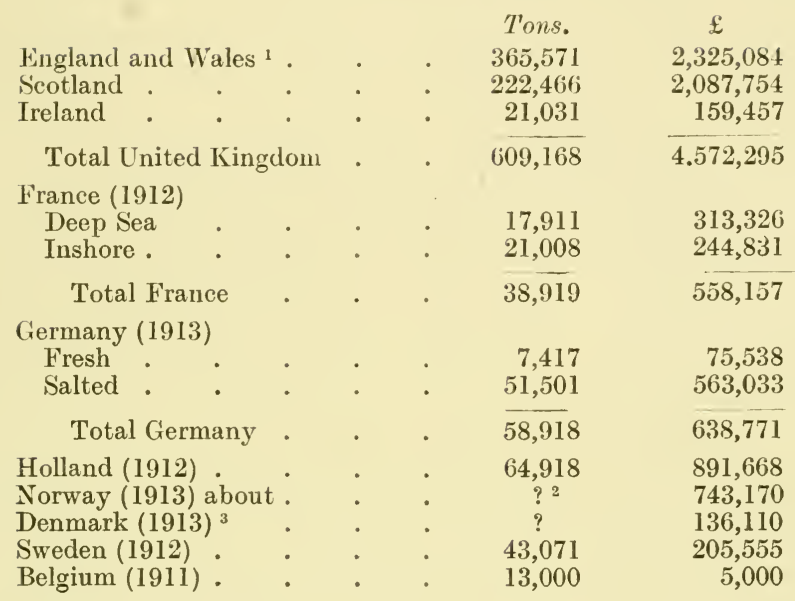

The British C'atch (Analysed), The Chief Herring Ports

At the outset it must be remembered that the great herringfleet is to a very considerable extent migratory. In the expressive, but not very accurate, phrase of the fishermen, the big boats (both English and Scottish) ' follow the herring round the coast'. It is approximately true, for instance, to say that Scottish vessels landed 55 per cent. of the steam-drifter catch in English ports, and 64 per cent. of that in Scottish ports. For the following figures the writer is indebted to Dr. T. Wemyss Fulton.

1 In 1920 the landings were :

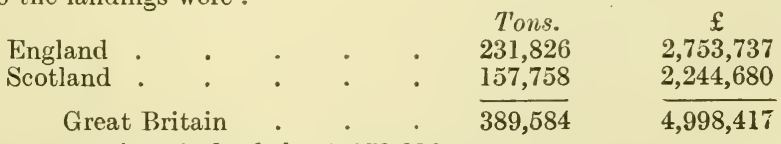

2 The figures are given in bushels $-7,973,316$.

3 The figures are given in 'scores' $-14,786,260$. 
The Quantities of Herrings and the Percentage proportion in each Month landed in 1913 at the Chief Ports and Districts of England and Wales

( $X=$ quantity too small to calculate)

\begin{tabular}{|c|c|c|c|c|c|c|c|c|c|c|c|c|c|}
\hline $\begin{array}{l}\text { West Coast } \\
\text { Scotland. }\end{array}$ & $\begin{array}{l}\text { Total } \\
\text { Tons. }\end{array}$ & క్ & $\stackrel{8}{0}$ & 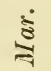 & हे & $\stackrel{\Xi}{=}$ & ఏ్త & ঙ্ & $\dot{\square}$ & हूँ & $\dot{\Xi}$ & हें & $\ddot{\Xi}$ \\
\hline ornoway & 26,212 & 26 & 33 & 11 & $x$ & 5 & 6 & 6 & 3 & 2 & 1 & 3 & \\
\hline arra & 5,9 & 0.7 & 3 & I & $0 \cdot 8$ & 27 & 46 & 16 & 4 & 3 & $x$ & 0.7 & \\
\hline rtwilliar & 5,990 & 33 & 21 & 4 & $x$ & 13 & 0 & 3 & \pm & 2 & 1 & 3 & \\
\hline eltow & 6,193 & 1 & 3 & 6 & 14 & & 2 & & 12 & 25 & 12 & & \\
\hline antrae & 2,662 & & 57 & $0 \cdot 2$ & 0.6 & & & & & 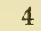 & $0 \cdot 4$ & 0.5 & \\
\hline
\end{tabular}

II. East Coast

Or 90 per cent. Scotland.

Shetland

Orkney

Wick

Buckie

Banff

Fraserburgh

Peterhead

Aberdeen

Anstruther

Eyemouth

$\begin{array}{rrrrrrrrrrrrr}35,464 & \times & 2 & 1 & 0 \cdot 3 & 31 & 41 & 6 & 13 & 5 & \times & - & - \\ 10,919 & 0 \cdot 1 & - & - & - & 3 & 24 & 37 & 34 & 2 & - & - & - \\ 21,364 & 7 & 3 & 1 & \times & 3 & 15 & 25 & 42 & 3 & \times & \times & \times \\ 1,039 & 3 & 0 \cdot 5 & 1 & - & 2 & 28 & 27 & 29 & 7 & - & - & - \\ 1,012 & \times & 0 \cdot 3 & 1 & - & 11 & 27 & 20 & 34 & 5 & - & - & - \\ 32,521 & \times & - & \times & - & 4 & 24 & 27 & 42 & 3 & - & - & - \\ 38,744 & - & 0 \cdot 2 & 0 \cdot 2 & - & 5 & 27 & 34 & 31 & 2 & - & - & - \\ 13,458 & \times & 0 \cdot 2 & 0 \cdot 1 & 0 \cdot 1 & 1 & 19 & 39 & 36 & 3 & 1 & \times & \times \\ 2,924 & 6 & 29 & 18 & 1 & \times & 10 & 23 & 10 & 2 & - & \times & \times \\ 5,713 & 0 \cdot 1 & \times & 1 & - & 6 & 31 & 39 & 15 & 8 & - & - & -\end{array}$

168,168

Or 99 per cent. of total of east coast catch.

III. East Coast England.

Berwick

Blyth

$2,946 \quad-\quad-\quad-0.5 \quad 21 \quad 49 \quad 23$

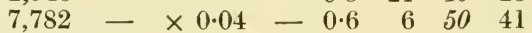

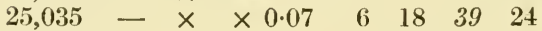

1,653 - $\quad \therefore \quad-\quad 3 \quad 29 \quad 3927$

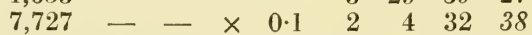

Sunderland

Hartlepool ${ }^{1}$

Scarborough

Hull 1

Grimsby ${ }^{1}$

Yarmouth

Lowestoft

$10,162 \times \times \times \times \times \times=74345 \times 4 \times$

$20,335 \times 2 \times \times \times \quad \times \quad \times \quad 2 \quad 16 \quad 46 \quad 32 \quad 3 \quad \times$

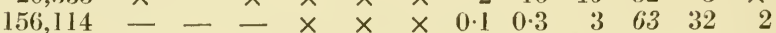

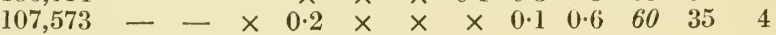

Or 99.7 per cent. of east coast catch.

IV. South Coast England.

Newhaven

Plymouth

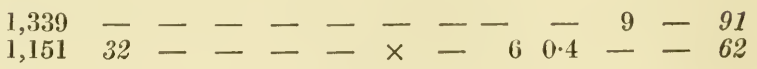

V. West Coast England.

Milford 1

Flectwood 1

$$
\begin{array}{lllllllllllll}
1,186 & - & \times & - & - & - & \times & 11 & 39 & 40 & 10 & \times & \times \\
3,312 & - & \times & - & - & - & - & 0.2 & 39 & 43 & 17 & 0.2 & - \\
7,922 & - & - & - & - & 0.3 & 1 & 23 & 60 & 16 & 0.2 & - & -
\end{array}
$$

1 Include trawled herrings, viz. 10,150 tons at Hull ; 6,950 tons at Grimsby ; 3,300 tons at Fleetwood; 2,950 tons at North Shields; 1,150 tons at Milford; 700 tons at Hartlepool. 


\section{The Movements of the Great Drifter Fleet}

Drifters (unlike trawlers) rarely remain at sea for more than two or three nights at a time, and a very large number of boats land their herrings daily. If they are 'lightly fished ', however, the first night's catch is salted, and the vessel puts in one or two more nights' fishing.

The Yarmouth and Lowestoft fleets fit out about the 1st of May for the east coast of Scotland, the Shetlands, and Castle Bay in the Island of Barra. In these waters they fish through May and June. By the second or third week in June the whole fleet is concentrated between the east coast of Scotland and the Shetlands. One of the chief bases of the fleet is Lerwick, and a big fleet fishes out of that port till the end of June. Then the centre of activity starts to shift southward to Orkney, Wick, Fraserburgh, Peterhead, and Aberdeen, where fishing is at its zenith in July and August. Some of the crews also use smaller ports like Buckie, Banff, Anstruther, and Eyemouth. Meanwhile, as the season advances, some of the vessels have felt their way south to the Tyne, Hartlepool, Berwick, and Seahouses, where the fishing is in full swing by the middle of July.

The southward movement continues, and in September a certain number of drifters are working from Scarborough and Grimsby. But by this time the bulk of the boats have crowded into Yarmouth and Lowestoft, both of which are, like North Shields and Hartlepool, sadly in need of increased and im. proved accommodation for the vast array of vessels. By the end of December the great herring fishery is over on the east coast. It was formerly the custom for many drifters to follow the mackerel fishing off the coast of Cornwall and the south coast of Ireland in January, February, March, and April. But this fishing ceased to be profitable when the French-our chief customers for mackerel-placed an import duty on the fish, and most of the English east-coast boats are now laid up during these months.

The 1913 herring ' harvest' was therefore (roughly):

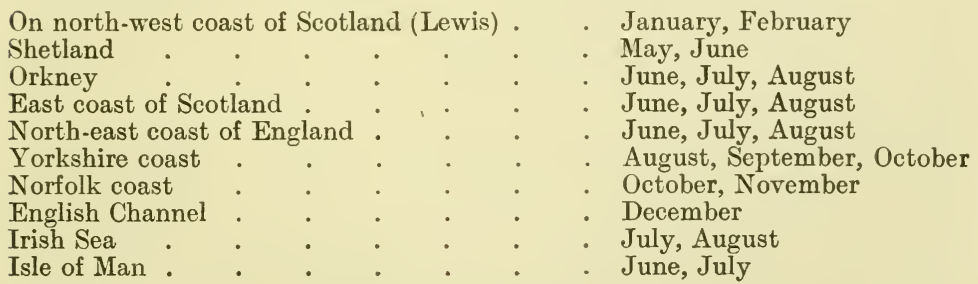

The figures show that the landings in any particular month 
are concentrated at a comparatively small number of ports, culminating in the great autumn assembly of 'drifters' in Yarmouth and Lowestoft.

Moreover, the herrings were landed chiefly by large vesselsthus steam drifters landed approximately :

In England and Wales

335,000 tons out of 365,000

In Scotland $\quad . \quad \therefore \quad . \quad 142,000$ tons out of 222,000

while the big sea-going motor-drifters landed 9,900 tons in England, and the best part of 18,000 tons in Scotland. These vessels-the big steam and motor drifters-are the backbone of the herring-fleets. The 'longshoremen' in England, for instance, caught less than 6,000 tons, and the big sailing drifters less than 15,000 tons. Even of the comparatively insignificant catch landed on the Irish coast a considerable proportion came out of a fleet of 140 Scotch and English drifters landing at ports like Mulroy, Rathmullan, Buncrana, and Londonderry. The application of steam and motor power to drifters, in fact, resulted in the fact that herrings came to be landed nearly all the year round.

More than 85 per cent. of herrings landed in England, and at least 95 per cent. of the others, were pickled and exported, chiefly to Russia and Germany; and much of the export to Germany found its way to Russia. Inasmuch as sophisticated people in this country refuse to eat pickled herrings, and as under no conceivable circumstances could a market be found for the immense British catch in a fresh or smoked condition, the herring industry is, as this is written, passing through troublous times, which are likely to last until Russians can once more import (and pay for) its chief product. But this commercial problem cannot here be more than indicated.

\section{Fluctuations in the Catch}

Right through the history of European fisheries, shoals of herring have been wont suddenly to desert waters which they have frequented for centuries. The classical example is the failure of the Baltic herring-fishery at Scania-the foundation of the wealth and naval power of the Hanseatic League-in the fifteenth century.

A hundred years later the Bohuslan fishery in Sweden failed, and remained barren for some seventy years. ${ }^{1}$ The herring fishermen of the day were, no doubt, prepared to explain these 'caprices'. In later times it was stated that the gun-fire at

1 The Sovereignty of the Seas (Fulton), p. 62. Also, The Sea Fisheries, pp. 131, 132 . 
the battle of Copenhagen in 1801 once again drove the herrings from the Baltic; the Long Island fishermen in the Hebrides thought at one time that their fish had left them because people had started making kelp; the modern Shetlander is convinced that herrings cannot remain anywhere near a whalingstation; the fishermen of St. Monance in Fifeshire used to put their church bell out of action in the fishing season as herrings were (notoriously) afraid of it; part of the Irish coast in 1835 lost all its herrings on the day that the Protestant rector decided to take tithe of the fish; and, of course, ever since trawls began to be used, first by sailing-smacks and then by steamers, nearly every drifterman has been firmly convinced that trawl-fishing somehow ruined his own trade.

On both sides of the Atlantic these disappearances of the herring from particular waters are known to occur. In the 'nineties', for instance, a winter spawning run into the Bay of Fundy ceased inexplicably, just as similar runs fell off in 1871-3, and again at the beginning of this century in Loch Fyne. Ocean research is faced with the task of explaining these fluctuations. It cannot be said to have arrived as yet at any solution-and we simply do not know why herrings desert and (sometimes) return to particular coasts which they have frequented. But the solution of the problem can be arrived at in one way only, by the patient study of the habits of herrings. And in this direction our knowledge has advanced considerably. 


\section{CHAPTER XXVIII}

\section{EGGS AND FRY OF THE HERRING}

\section{Spawning}

Herrings were first propagated in captivity in America in the year 1878. ${ }^{1}$ A female of average size produces between 20,000 and 47,000 eggs, and the average is approximately 30,000 . The eggs vary from one-thirty-third to one-twentieth inch in diameter. ${ }^{2}$ They are deposited on the bottom. They are ' covered with a glutinous material which soon hardens in contact with the water', and so they become attached to plants, or stones, or gravel, or any other substance with which they happen to come into contact-sometimes in bunches as big as walnuts, or larger. The period of incubation discovered by the Americans, from averages based on the handling of very large numbers of eggs, is about forty days at $33^{\circ} \mathrm{F}$. and about eleven or twelve days at $55^{\circ} \mathrm{F}$. Meyer's laboratory experiments in 1874, in Germany, gave about forty days at $38^{\circ} \mathrm{F}$., and about eight days at $58^{\circ} \mathrm{F}$.

The Americans found that sudden and extreme variations between $33^{\circ} \mathrm{F}$. and $53^{\circ} \mathrm{F}$. had no harmful effect on the eggs ; they merely retarded or hurried the hatching. But when eggs were hatched at a temperature below $33^{\circ} \mathrm{F}$., many of the larvae were deformed-and a deformed fish larva always dies very quickly. The sea temperature at a depth of 50 fathoms on this side of the Atlantic does not fall so low as $32^{\circ} \mathrm{F}$. until one is well north of Iceland, and round the British coast it is between $46^{\circ} \mathrm{F}$. and $50^{\circ} \mathrm{F}$. On the main herring spawning-ground to the south-west of Norway it is between $46^{\circ} \mathrm{F}$. and $42^{\circ} \mathrm{F}$. The danger of the eggs suffering from the effects of cold on this side of the Atlantic is accordingly much more remote than on the American side, where the $32^{\circ} \mathrm{F}$. line at 50 fathoms passes well south of Newfoundland, westward towards the Nova Scotian shore. ${ }^{3}$

${ }^{1}$ Cf. Manual of Fish Culture, p. 226-7 ; British Food Fishes, p. 455 ; Migrations of Fish.

2 Herring eggs with a diameter of 0.035 and 0.039 inch run respectively $1,578,000$ and $1,150,000$ to the quart. The Norwegian eggs run 347,000 to the quart with a diameter of $0.058 \mathrm{inch}$. In America the average is 541,000 to the quart (average diameter 0.050 inch).

${ }^{3}$ Cf. p. 187 below (fig. 20). 


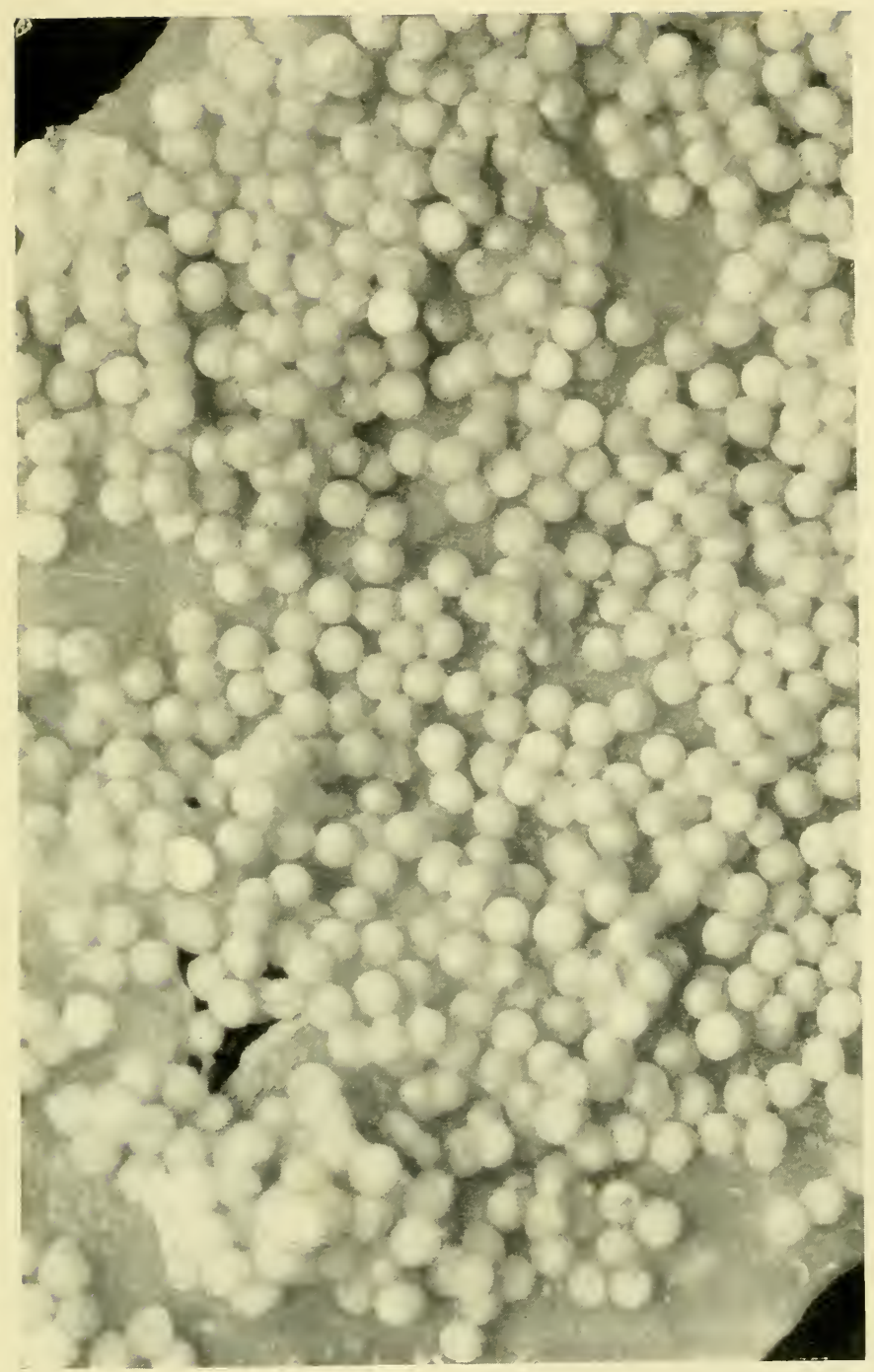

HERRING EGGS ON SEA WEED

(Photograph by Mr. A. Scott.) Magnified about 5 times. 



\section{The Spawning Grounds}

In $1860^{1}$ Dr. Boeck made certain experiments for the Norwegian Government. He netted the channel between Raagö and Faejo in Vordingborg Bay (Great Belt) with a line of nets stretching towards Hauskeskaer; he also made another chain of nets, which stood for the most part on rocks, with one end reaching the channel. All the nets in the channel caught many ripe herrings; those on the rocks caught none, except where they projected into the channel. With the dredge he raised large lumps of herring ova attached to and mixed with gravel. He concluded that in calm weather the herrings' favourite spawning places were 'large level places at the bottom of the sea covered with rough gravel'.

In 1803 Dr. Walker, of Edinburgh University, had also found that the eggs were deposited on a gravelly bottom at about 10 to 12 fathoms. In 1862, Mitchell ${ }^{2}$ relates, divers employed by the Fishery Board for Scotland found herring-spawn to the west of the Isle of May in the Firth of Forth at 15 fathoms at the beginning of March-the bottom being stones, shells, sand, and shingle. On the east side of the island spawn was found on coarse shelly sand at 20 fathoms. The deposit was about three-quarters of an inch thick, and attached to a cake of the rough shells and sand. Three weeks later all the spawn had disappeared from both of these spawning grounds.

Mitchell says that 'after remaining on the coast for a certain number of weeks, the herring deposits its spawn on hard clayey or rocky ground, or gravel'. He tells us that Sauer had observed the actual spawning process in the inner harbour of St. Peter and St. Paul, Kamschatka. There, on the 7th June, 'the herrings made circles of about six feet in diameter, and in the middle of the circle, at the bottom, another, no doubt the female, was fixed.' The female first ejects the whole of the ova, which is afterwards impregnated by the milt.

Since Mitchell wrote, herring spawn has been obtained from a gravelly bottom in the Firth of Clyde (Ballantrae Bank) in rather shallow water; and Jenkins ${ }^{3}$ has observed the Baltic herring spawning in a few feet of brackish water in the river Schlei, and attaching their eggs to the freshwater " pond weed ' ! The Japanese claim to have discovered that their herring, which is the same species as ours, spawns, not at the bottom at all, but among beds of seaweed along the shore. Meek, on p. 71 of his book, gives a map which marks spawning grounds

1 British Marine Food Fishes. ${ }^{3}$ Sea Fisheries, p. 97.

2 The Herring (1864), p. 341. 
in the Minch, south of Shetland, off the Moray Firth, and off the coasts of Berwickshire and Yorkshire; he also marks one (apparently) on the Dogger, and another offshore from the Norfolk coast somewhere between the Dogger and Brown Ridges. These grounds have apparently been located rather roughly by observing the positions in which 'ripe' herrings occur. On the Norwegian coast no 'ripe' herrings are caught except between Stavanger and Romsdal, i. e. on the Norse coast of the North Sea ; and G. O. Sars based on this fact his accepted theory that the south-west coast of Norway was the only spawning ground for Norwegian herrings. The depth here is from 40 to 100 fathoms ${ }^{\mathbf{1}}$ and the temperature, apparently, about $42 \cdot 8^{\circ} \mathrm{F}$. at the shallower depths, rising to $44 \cdot 6^{\circ} \mathrm{F}$. at 100 fathoms. ${ }^{2}$

It must be admitted, however, that information as to the spawning habits and spawning grounds of those herrings which are really the important part of the catch-the shoals which annually invade our eastern coasts-is extremely meagre. It is natural that the drifter industry-in the person of Mr. J. Bloomfield, of Yarmouth-should have demanded further investigation into these subjects ${ }^{3}$ from the 1908 Committee. Dr. Allen told the same Committee that 'the prospect of benefit (from researches into herring life) is rather in the direction of showing the fishermen where and when they can best catch them. I think there is a distinct prospect of being able, at some future time, to tell the fishermen where to shoot their nets and where not, with the prospect of catching fish'. This end he hoped to obtain largely by the study of the effect of temperature and other water conditions on the distribution of the fish. Yet in 1916 Professor Meek ${ }^{4}$ was compelled to admit that no one knew whether our herring-shoals came from the Atlantic Ocean or the Norwegian Sea, or simply moved in from deep water in the North Sea to the shallows; that no one knew whether the whole North Sea was 'one large spawning area' with certain regions especially adapted for the reproduction of herrings, or whether there were many spawning grounds each frequented year after year by its own particular school of herrings. There is much room here for further and continuous investigation right through the year, and the herring industry is naturally anxious that it should proceed. Meanwhile it is time to lay stress on the fact that there are two distinct spawning seasons. One main group of herrings spawns in the spring, and another in the autumn. Off the east coast of Scotland the principal

1 Depths of Ocean, p. 712.

3 Cd. 4304 (1908), p. 420.
2 Depths of Ocean, p. 709, Fig. 509.

4 The Migrations of Fish, p. 82. 
spawning season is said to be May to August; off the east coast of England, July to November. Off Plymouth, on the other hand, herrings spawn in December and January. The mean surface temperature of the water in December in 1919-20 was :

\begin{tabular}{|c|c|c|c|}
\hline & & $\begin{array}{c}\text { Dec. } \\
\text {. } 50 \cdot 1^{\circ} \mathrm{F} .\end{array}$ & $\begin{array}{l}\text { Jan. } \\
47 \cdot 4^{\circ} \mathrm{F} .\end{array}$ \\
\hline Poin & . & . $51 \cdot 8^{\circ} \mathrm{F}$. & $49 \cdot 6^{\circ} \mathrm{F}$. \\
\hline
\end{tabular}

\section{The Influence of Temperature}

It would be interesting to have a comparative table of the surface and bottom temperature of the sea on all grounds on which herring are known to spawn all round our islands for the whole spawning period. If such a table has been prepared it has never been made public in any popular form. The Cardigan Bay herrings spawn in October and November with water at about $55^{\circ} \mathrm{F}$. to $52^{\circ} \mathrm{F}$. (surface). Dutch investigators maintain that herrings are most plentiful in water between $53.6^{\circ} \mathrm{F}$. and $57.2^{\circ} \mathrm{F}$, and all Dutch herring-boats carry thermometers in order to enable them to fix their nets at the proper level. ${ }^{1}$.

Some years of observations at Wick with the deep-sea thermometer showed that the best catches were made with a day temperature of $55^{\circ} \mathrm{F}$. falling to $54^{\circ} \mathrm{F}$. at night, and that a fall below $53^{\circ} \mathrm{F}$. meant no fish at all. Boeck, in his report to the Norwegian Government in 1862, made careful observations on temperatures. He found (after a spell of cold weather) that the water at 10 fathoms was about $35^{\circ} \mathrm{F}$. or $36^{\circ} \mathrm{F}$. There no fish were caught. But when the nets were lowered to 50 or 60 fathoms and a temperature of $39^{\circ} \mathrm{F}$. to $41^{\circ} \mathrm{F}$. the eatch was good.

It was believed by Frank Buckland that herrings rise from the bottom as temperature increases, and swim at a higher level during the spawning season. Mr. C. C. Morley, of Milford, however, stated that his trawlers only caught herrings off Ireland at 60 fathoms when the weather was 'very hot'.

\section{Development of the Fry}

Herring larvae, when they hatch out, vary (according to the ' race' they belong to) from $0 \cdot 19$ to 0.31 inch in length. They absorb the yolk-sac very quickly, and remain at the bottom during the process. During January and February this year (1920) 1,032 young herrings, varying from 0.31 to 0.58 inch in length, were caught off Plymouth. They were examined by

1 Stacey Watson, Silver Hosts of the North Sea, p. 18. 
Dr. Lebour, who found that 725 of them contained no perceptible food at all. The yolk-sac, which is absorbed, it is believerl, in three or four lays, was present in the case of many specimens up to $0 \cdot 35$ inch long, but Dr. Lebour has long since discovered that the larvae start feeding-as do young turbotwhile the yolk-sac is still present and when they are no larger than 0.27 inch. Their diet seems to be varied. In the very early stages, herrings feed largely on greenish matter, diatoms, and single-celled animals like peridinians, ${ }^{1}$ flagellates, and infusoria. At a later stage they contain the free-swimming larvae of snails (gastropods), bivalves, copepods, and barnacles ; also young adult copepods and other small animals.

Reference has already been made more than once to Einar Lea's discovery that whole broods of Norse herrings have perished in certain years-and this point will be again referred to. It is fairly clear to the writer's mind that the eggs of herrings are not in much danger except from predaceous fish and animals. Does famine wipe out whole broods of baby herrings during the critical days when they are living on the yolk-sac and gradually acquiring the habit of digesting other food? If so-imasmuch as baby herrings live at the bottom till the sac is absorbed, and at mid-water for some months afterwards, what causes this famine? Why-if ever-are the minute plants and animals, on which baby herrings feed, absent from the bottom or the middle waters during the few weeks in which the fish must find them or die? Answers to these questions might help herring-curers and exporters to forecast their harvests years ahead. And yet-just because .Science nerer explains-curers and exporters are apt to speak with very scant respect of investigations so 'unpractical' as the study of 'plankton'.

Dr. Fulton maintains that adult herrings get most of their food in the water which they 'exhale' in the process of breathing. Just as the Greenland whale and the blue whale, with their huge tongues, press the water out of their mouths through a whalebone fringe which entangles the tiny animals on which they live, so does the herring strain the water through the fine grating formed by its gill-rakers, for the food which is floating in it. It follows, therefore, that though a herring can, and does, pick out any particular object which takes his fancy-including (sometimes) a trout-fly - he does not as a rule discriminate much in his diet. If the animal is caught in the gill-rakers it is

1 Peridinians are claimed as plants by botanists, and as animals by some zoologists! Flagellates have no skeletons, but are apparently distinctly 'animal'. 


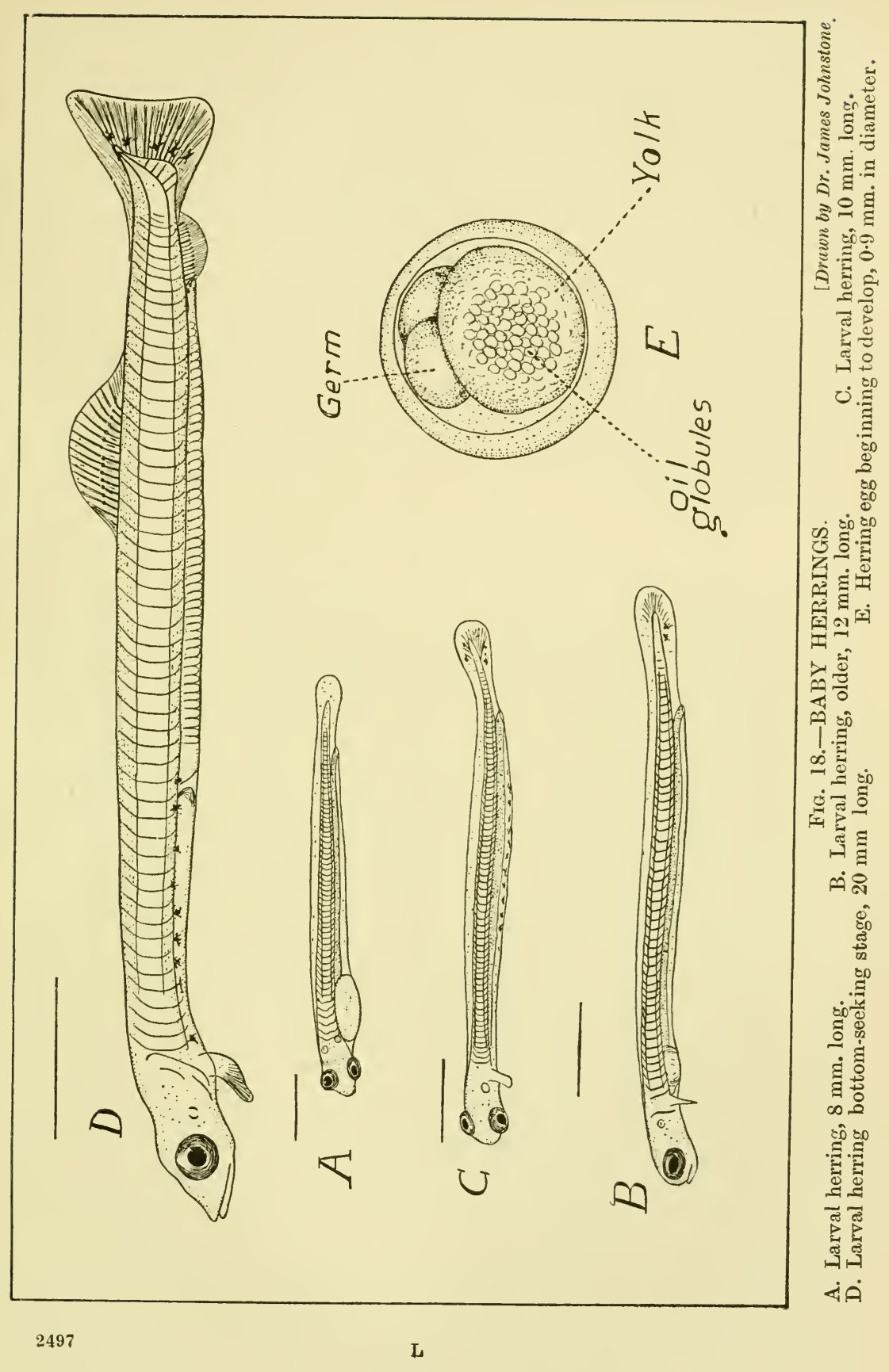


swallowed. At what stage this infiltration of food begins, the writer does not know. It does not (presumably) apply to the early stages before the gill-rakers are formed. Growth is not very rapid. Fulton ${ }^{1}$ tells us that a spring herring in the North Sea is rarely more than 2 inches long at the end of the year in which it was hatched, and most are much smaller; at the same period an autumn herring may be just over half an inch long, and is rarely over $1 \frac{3}{8}$ inch. $^{2}$

All through the early stage the young herrings are gradually moving upwards into higher layers of water, and somewhere about the end of June the 'spring' brood-then about an inch long-reach the surface, and begin to wander shorewards. They now begin to put on their silver scales, an attraction to the enemies which prey upon them, as every one knows who has watched summer shoals of mackerel hunting herring-fry inshore at this stage.

\section{Whitebait}

With the appearance of the scales the herring has assumed the adult form. On its first journey shorewards it is caught as 'whitebait', especially in the fine meshed seines at Leigh and Southend, and apparently in the Medway. These seines are used for whitebait from April to September, when the majority of the fish are herring fry. The Thames whitebait in June, for instance, consist of 90 per cent. of herrings. They are then, according to Ewart and Matthews, ${ }^{3}$ about six months old; measure about 2 to $2 \frac{3}{4}$ inches ; and are probably the progeny of fish spawning in the Channel in the winter. The winter whitebait caught in the Thames 'stow-nets' consist chiefly of sprats. Mr. Andrew Scott found that the whitebait in the Menai Strait consisted of a majority of herrings in March, and on the 28th May nearly all were herrings measuring $1 \frac{1}{2}$ to $2 \frac{1}{2}$ inches; but by August all the whitebait consisted of young sprats. Numbers of young herring, $1 \frac{1}{4}$ inch to 2 inches long, come inshore at Cullercoats every July and August. The development after this stage is bound up with the question of 'herring races' and scale reading.

1 Twenty-fourth Ann. Rep. Fish Bd. Scot., Part 3, p. 293.

2 But see Mrs. Cowan's more recent investigations, below, p. Iit

${ }^{3}$ Fourth Ann. Rep. S. F. B. 


\section{CHAPTER XXIX}

\section{ADULT HERRINGS (RACES AND SCALE READING)}

\section{The Races of Herring}

HJort 1 tells us that fishermen have long discriminated between the herrings from the Dogger Bank, from Shetland, from the Skagerrak, and from the coast of Norway. Science proceeded to investigate the fisherman's knowledge and was for some time 'at fault'. It could merely corroborate facts already ' known' to practical men-that, for instance, the 'Shetland ' and Dogger Bank herring spawned in the summer and autumn ; the Norse coast herring spawned in the spring; and 'fat' herring never contained ripe roes or ripe milt.

Then Heincke proved that there really were differences in structure between the different sorts of herring. Large collections from all countries were made under the auspices of the International Council, and were examined by the Norwegiansespecially by Broch. By 1907 it was determined that the follow. ing races were probably distinct:

(a) Dogger Bank Herring. Caught off the east coast of England and Scotland, on the Dogger Bank, on the Great Fisher Bank, and in the southern portion of the Skagerrak. They are comparatively small ( $9 \frac{1}{2}-10$ inches), have 56 vertebrae, and are ' full herrings' in August, which means that they spawn about a month later.

(b) Shetland Herring. Caught in the northern waters of the North Sea, on the west side towards Scotland and the Shetlands. This is larger than the Dogger Bank herring, and is about $11 \frac{3}{4}$ inches when ripe. It has rather more than 56 vertebrae. It spawns in July and August, and is 'spent' in September and October. ${ }^{2}$

(c) The Norse Herring. This occurs in the same waters as the Shetland herring, sometimes with it, and sometimes separately. This is the largest herring, and has the largest number of vertebrae. It spawns in the spring along the south-west coast of Norway, is a 'mattie' in July and August, and a ' full ' herring not before November.

1 Some Results of the International Ocean Researches, 1907.

2 But spring spawning also takes place all the way between Shetland and the Butt of Lewis, see below, p. 173. 


\section{Scale Reading}

Mr. Broch was the first to investigate and describe the theory that herring-scales were marked with rings which made it possible to tell the age of the fish and other important facts in its life-history. The scales of the Norse spring herring, for instance, show that the fish grow regularly up to the fourth or fifth year; from that time the scale grows much more slowly, and from eight to twelve years old the "winter rings ' are closer and closer together; and it has been found that many thousands of scales examined all showed the same type. These herrings are caught during their spawning season from January to April. Some of their progeny are carried into the fjords and apparently remain on the north coast. At any rate, in the fjords is caught all the year round a very small herring known to fishermen as a 'fjord herring', and it is known that it comes from the big spawning ground on the south-west coast of Norway. These fish, although they belong to the same 'race' as the spring fish, stop growing a year or two earlier.

\section{Autumn Spawning}

Then the scales of the 'Shetland' herring grow continuously for eighteen months before the first dark ring is formed. They are hatched out in July or August, and their babies apparently continue to feed steadily through the first winter. In their second winter (when they are $1 \frac{1}{2}$ years old) they go off their feed, and the first winter ring forms. So these herrings have a relatively large first-year scale, and the same thing is true of the Skagerrak herrings, which also spawn in the summer. This being known, it becomes possible to take a catch made (say) on the Viking Bank, or off Lowestoft, and say at once that it was composed of $x$ per cent. of spring fish, and $x$ per cent. of autumn fish; and when the scales of herring taken from drift-nets all over the seas are compared, it will, Hjort says, be possible to trace the wanderings and distribution of the different shoals with extraordinary accuracy.

Even off Lowestoft both spring and autumn spawners are caught. There is found, in addition to the Dogger Bank herring, which spawns in the summer and autumn, a small variety which does not grow to more than $9 \frac{1}{4}$ inches, and spawns when it is three or four years old. This has a relatively small first-year scale growth and a relatively big one in the second year, after which the growth steadily decreases. It is therefore hatched in the spring, and quite distinct from the 'Dogger' herring. 


\section{Age Distribution in the Shoals}

By studying the scales Hjort and Lea are able to say what proportion of fish hatched in any particular year are contained in a haul, and this can be determined especially easily off the Norwegian coast, where herrings are caught in seine-nets which retain fish of all sorts and sizes. Drift-nets and trawls do not, of course, catch fish below a certain size, and are consequently much less useful than purse-seines for purposes of herring research. A haul in the spring of 1907 , for instance, gave Hjort 924 fish ; the vast majority were from four to eight years old ; very few indeed were as young as three years old, and none younger ; there were rather more "nine-year-olds' and "twelveyear-olds ' than 'three-year-olds' ; and very few of ten, eleven, and thirteen years. Four-year and eight-year-old fish predominated over all other years.

Amongst other things, Hjort from these observations ' definitely settled for all time ' that Norwegian herrings spawn from three years to at least fourteen years of age; and that the 'matties' or maiden fish are between one and a half and four years old. Following up this line of investigation, Hjort and Lea have proved that the 'fjord herring', the 'large herring ' caught off Romsdal in late autumn and winter, and the 'fat herring' caught off the northern coasts in autumn, are all fish spawned off the south-west coast in the spring, at different stages of their development.

They found that the 1904 brood, like that of cod and haddock, was especially plentiful. It was, moreover, quite peculiarly marked by a very small growth in its third year. ${ }^{1}$ This brood was confined to the north coast of Norway in 1907, and up to September 1908. In the autumn and winter of 1908-9 and 1910 some of them appeared among the 'large herring' off Romsdal ; and in 1910 they made their first appearance among the spawners on the south-west coast. They were then in their sixth year; and in course of the year they were caught in the Faeroes, the Skagerrak, the Kattegat, and in the southern portion of the North Sea. Their numbers were so great that even last year (1919) these 1904 fish formed a large proportion of the Norwegian catch, though they were then fifteen years old. On the other hand, the spawning seasons 1905 to 1909 inclusive appear to have been much less productive.

In 1913 Dr. Hjort found immense numbers of one-year-old herrings and cod which had been spawned in 1912, and this brood began to appear in large numbers in the catches at the end of

2 Depths of Ocean, p. 765. 
1917 when they were five years old, and were also largely preponderant in 1918 and 1919.

There is a school of thought which challenges the efficacy of this scale reading, and it may, of course, be able to discredit it. But if Hjort and Lea are correct, it is obvious that they are within measurable distance of being able to make a forecastyears ahead - of the Norwegian herring harvest, and to explain the fluctuations which have puzzled so many generations of fishermen.

Their main conclusions are that the age of the fish preponderating in the stock of herrings varies very greatly from year to year, or in Hjort's own words :

"The age composition of a fish stock varies exceedingly; there are good and bad years, producing annual classes rich or poor in individuals; favourable and unfavourable conditions must thus vary in nature, and seem to affect specially the earlier phases in the life of the fish, inasmuch as we perceive that in advanced years the numerical preponderance of an annual class is equally perceptible for a number of years. . . . Wherever there is a good opportunity of obtaining representative samples showing the age composition of a fish stock, it should be possible to predict the composition of that stock for the following years.... The results here mentioned have been obtained through laborious investigations occupying many years, involving the study of the fishes at all seasons, in order to prove that the various growth rings of the scales really correspond to seasonal changes.' 1

\section{Norwegian Scale-reading Methods}

Scale reading in Norway, then, resolves itself into the following procedure: (1) A sample of herrings is obtained from a certain ground.. (2) The size and sexual development of each fish is noted. (3) The scales are examined, the winter rings counted, and the age of each fish is determined. The results were plotted as follows for samples of 'fat' herrings caught off the north coast of Norway in the autumn :

Age of Herring.

\begin{tabular}{|c|c|c|c|c|c|c|c|c|}
\hline (Ycrirs). & & I & II & III & IV & V & VI & VII \\
\hline $1907 \%$ & - & . 11.5 & $36 \cdot 8$ & $51 \cdot 3$ & 0.4 & - & - & - \\
\hline $1908 \%$ & . & $0 \cdot 4$ & $51 \cdot 4$ & $10 \cdot 3$ & $37 \cdot 8$ & - & - & - \\
\hline $1909 \%$ & . & $3 \cdot 1$ & $61 \cdot 0$ & $13 \cdot 3$ & $5 \cdot 0$ & $16 \cdot 9$ & 0.7 & $0 \cdot 2$ \\
\hline $1910 \%$ & - & $0 \cdot 2$ & $50 \cdot 7$ & $42 \cdot 0$ & $0 \cdot 9$ & 1.7 & $4 \cdot 6$ & $0 \cdot 1$ \\
\hline
\end{tabular}

It was noted that the fat herrings of 1907 consisted mainly

1 Depths of Oceun, p. 768. It is surely quite easy to obtain (as indeed Storrow has done) samples representative of the catch at any British port. 
of two-year and three-year-old fish, in 1908 of two-year and four-year-olds, and in 1910 of two and three-year olds. The three-year-olds of 1907 were (obviously) four years old in 1908 and so on, and the broods born in 1904 and 1907 are printed in black heavy type. Both these spring spawning seasons at once appear to have produced an unusual number of healthy fry. When they are four years old the fat herrings leave the shoals of immature herrings, and join up with the spawners. Samples of these spawners were examined, and the scales showed that the brood fish each year contained the following percentage of herrings born in 1904 :

\begin{tabular}{|c|c|c|c|c|c|}
\hline 1908 & & & & & $34.8 \%$ \\
\hline 1909 & • & • & & • & $43 \cdot 7 \%$ \\
\hline 1910 & • & . & - & . & $77 \cdot 3 \%$ \\
\hline 1911 & • & . & . & - & . $70.0 \%$ \\
\hline
\end{tabular}

Hjort and Lea had thus proved to their satisfaction that the 1904 brood was so enormously prolific that the herring stock in certain years contained more 1904 fish than fish of all the other many years represented in the samples put together. All this they described in their paper 'Some Results of the International Herring Investigations, 1909-11' (Publ. de Circonstance, No. 61, Copenhagen 1911). Most unfortunately, no popular account of this work has been given to the British herring-trade.

Since its publication Dr. Hjort has, as we have seen, been able to show that the 1912 brood was also abnormally prolific. $\mathrm{He}$ is now concerned to determine what conditions prevailed in the Norwegian Sea in the springs of 1904 and 1912 which would account for this great access of young herrings. $\mathrm{He}$ is disposed, apparently, to connect the good years with an abnormal spring harvest of diatomic plants on the sea-bed during the period when the herring larvae first begin to supplement the contents of their yolks with supplies of sea-food. ${ }^{1}$ Clearly, if that point can be proved, the investigator of the future will be able to note the amount of diatomic food in the water on the Norwegian herring spawning grounds during the hatching season, and to tell the fisherman whether there will or will not be a big catch of herrings of this particular brood two, three, or four years later.

\section{Scale Reading in Britain}

This consummation will not be arrived at unless the age of fish can be accurately determined by their scales. And herringscale reading in this country is complicated by the fact that our

${ }^{1}$ See pp. 94-6 
herring harvest is composed partly of fish spawned in autumn and partly of spring herrings. Still, if Hjort and Lea establish their hypothesis in the case of the Norwegian spring spawners, the application of their method to British herring fisheries is only a matter of time, and Mr. Storrow and Mrs. Cowan have, in fact, since 1911 been conducting at the Dove Marine Laboratory, Cullercoats, an invaluable series of observations on herrings landed by British vessels.

Their operations from 1911 to 1914 are summarized by

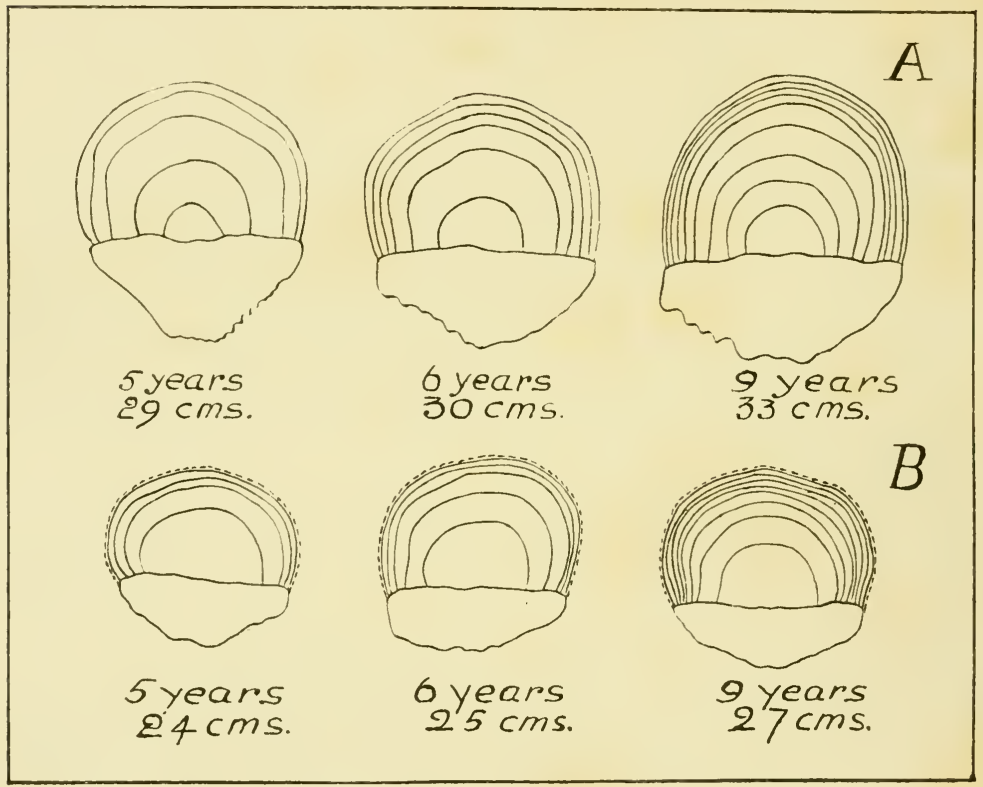

Fig. 19.-SCALES OF HERRING. (After Hjort.)

A. Norse spring herrings. B. Shetland herrings, spawning in autumn, Note relatively large size of centre of scale. $1 \mathrm{~cm} .=\cdot 39$ inches. The sizes of the fish to which the scales belong are given in centimetres. $29 \mathrm{~cm} .=$ $11 \cdot 3$ inches, $30 \mathrm{~cm} .=11 \cdot 7$ inches, $35 \mathrm{~cm} .=12.9$ inches, $24 \mathrm{~cm} .=9 \cdot 3$ inches, $25 \mathrm{~cm} .=9 \cdot 7$ inches, $27 \mathrm{~cm} .=10.5$ inches. (From Depths of Ocean.)

Professor Meek on p. 75 of the Migrations of Fish. Professor Meek tells us (p. 73) that the herring 'only feeds and grows during the warmer months of the year, from about the beginning of April to October ; from October to April growth is practically suspended,' and that the stationary winter period is marked on the scales by ' narrow transparent rings' which he calls ' winter rings'. 'In the case of winter and spring spawners,' he tells 


\section{PLATE X V I}
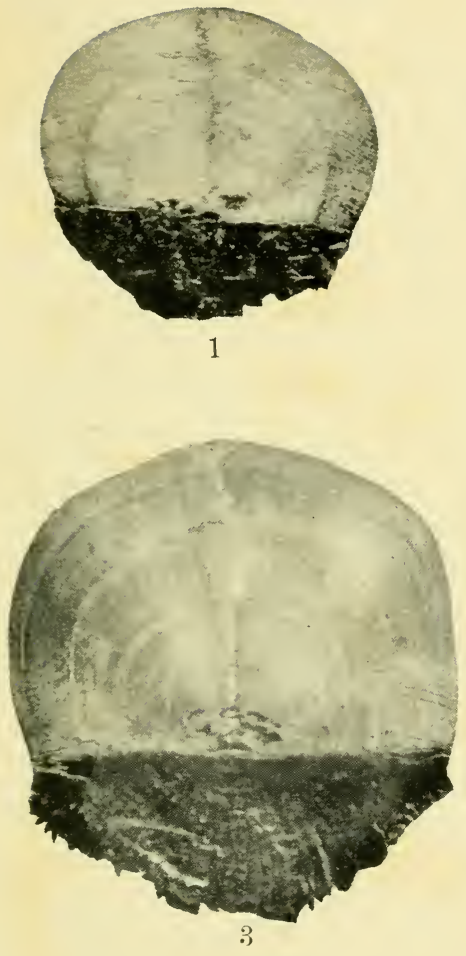

SCALES OF HERRING (Meek)
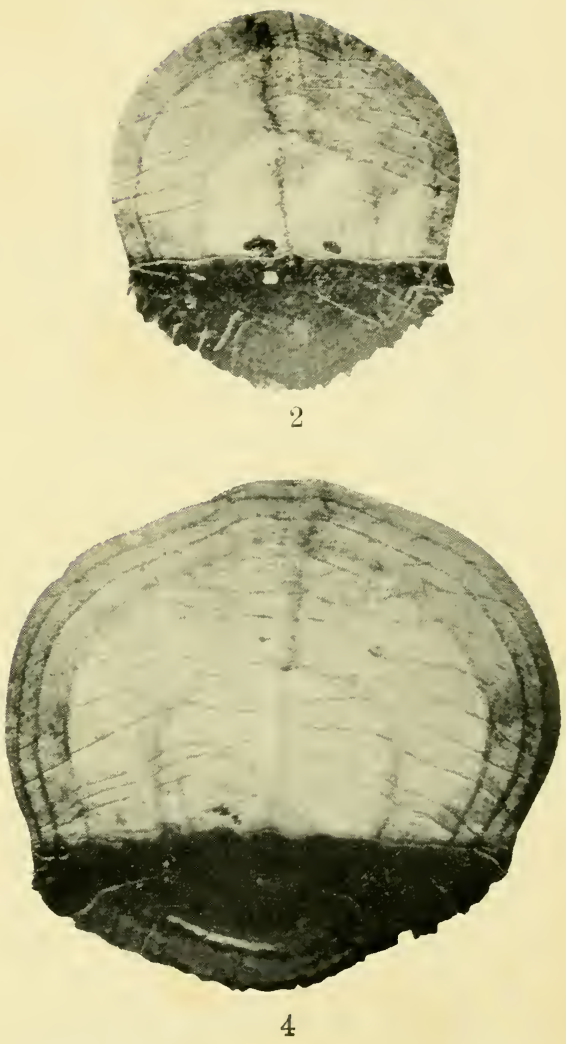

(1) One winter ring; (2) two winter rings; (3) three winter rings;

(4) four winter rings. Magnified about 10 times. 

us, " the young will have time to form the scale, and the following winter will be recorded; but obviously in autumn spawners, the first winter ring will refer to the second winter.' He thus follows the Norse theory that the autumn-spawned herring carries its birth-mark all through life in the shape of a scale marked with a first winter ring, which is relatively distant from the centre of the scale. The point is important as Storrow is not convinced that autumn fish can thus be distinguished from the spring herring.

Between 1911 and 1914 observations were made on two schools of herring-the Northumberland coast herring which are caught in drift-nets, and which spawn from the middle of August to the beginning of September ; and the Dogger Bank herring caught in trawls, which spawn from the end of September to the middle of October. It is important to remember here Hjort's warning on p. 165, that the seine-net is a much better instrument than either the trawl or the drift-net for the purpose of herring investigations, because it retains fish of all sorts and sizes, whereas the meshes of the trawl and drift-net allow the youngest fish to escape, and do not in fact ever catch more than 1 per cent. or 2 per cent. of herrings marked with one winter ring.

The observations showed that the annual percentage of various broods of herrings in the samples were as follows:

\section{(1) Northumberland Coast Herrings}

$\begin{aligned} & \text { Number } \\ & \text { of } \\ & \text { Winter } \\ & \text { Rings. }\end{aligned}$
$1912 \%$
$1913 \%$

The tranverse lines indicate the history of each brood through the period of three years, which is, needless to say, much too short a period to form a cycle. The interesting points which emerge are that fish between three and four years old formed a very large proportion of the samples in all three years; that the 'four ringers' were common in 1912 and 1913 but not in 1914, and the 'two ringers' in 1914 but not in 1912 or 1913, and that few of the fish are over six years old. 
(2) Dogger Bank Herrings

\begin{tabular}{|c|c|c|c|c|c|c|c|c|c|c|c|c|c|c|c|}
\hline $\begin{array}{c}\text { Number } \\
\text { of } \\
\text { Winter } \\
\text { Rings. }\end{array}$ & ـ & - & $\Xi$ & Z & 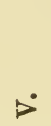 & $\stackrel{\triangleright}{\triangleright}$ & $\stackrel{5}{B}$ & 当 & $\dot{A}$ & $\dot{x}$ & 牙 & & & $\vec{X}$ & $\begin{array}{l}\text { Over } \\
\text { Six } \\
\text { Years } \\
\text { old. }\end{array}$ \\
\hline $1911 \%$ & 1 & $\begin{array}{c}(a) \\
36\end{array}$ & $\begin{array}{c}(b) \\
22 \\
(a)\end{array}$ & $\begin{array}{r}9 \\
(b)\end{array}$ & 9 & 4 & 4 & 9 & - & & 5 & & - & & 24 \\
\hline $1912 \%$ & 2 & 5 & 13 & $\begin{array}{l}11 \\
(a)\end{array}$ & $\begin{array}{r}4 \\
(b)\end{array}$ & 12 & 11 & 12 & 5 & 12 & 10 & & & $I$ & 67 \\
\hline $1913 \%$ & 2 & 18 & 13 & 26 & $\begin{array}{l}17 \\
(a)\end{array}$ & $\begin{array}{r}5 \\
(b)\end{array}$ & \pm & 3 & 3 & 0 & 1 & & & & 2 \\
\hline $1914 \%$ & 1 & 8 & 25 & 16 & 29 & 10 & 4 & 2 & 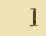 & & 1 & & & & 21 \\
\hline
\end{tabular}

The Dogger herrings caught in the trawls therefore seem to have consisted in all three years largely of fish belonging to the (a) 1909 and (b) 1910 broods, and they included in all four years a considerable number, and in 1912 no less than 67 per cent. of fish over six years old.

So far there is here no conclusive evidence for or against the application of the Norwegian theory to British herrings. But it is apparent that inquiries along these lines might eventually enable us to decide whether particular 'broods' of herring survive in some years in abnormal quantities, and whether these broods appear to preponderate in the catches of subsequent years. They might further show why some years were 'good 'for herring and others 'bad'. To arrive at the cause it would, of course, be necessary to know whether the brood in question had been hatched in the spring or in the autumn, and to discover the conditions, such as the amount of food and the water temperature on the bottom of the spawning grounds which prevailed during the babyhood of the fish.

Mr. Storrow and Mrs. Cowan continued their inquiry right through the war with the cordial co-operation of the fishermen at North Shields. They have not, it is true, hitherto been able to indicate whether, and if so why, the parent herring is more or less likely to produce a large and healthy family in one year than in another. They have, therefore, not as yet added very much to our chance of solving the all-important problem of fluctuations in the herring-stock on the lines laid down by the great Norwegian naturalists. But they have not worked in vain.

In $1919 \mathrm{Mr}$. Storrow showed good reason for believing that some of the herrings which spawn during the spring in the Firth of Forth were supplied from the shoals which feed off the Northumberland coast during the summer. In February 1920 he examined 54 herrings; all of these were over 7.8 inches long 
at the end of their third year of growth; only four were less than $9 \frac{1}{2}$ inches ; and 33 fish were over $9 \cdot 8$ inches. In March, 67 out of 85 fish examined were, at the end of their third year's growth, over 9.8 inches in length, and only eleven fish were under $9 \frac{1}{2}$ inches. Mr. Storrow tells us that he has found no herrings which grew at this rate anywhere south of the Firth of Forth except a very few landed at North Shields, and for this reason, and because the older fish examined are also much larger for their age than herrings from southern waters, he propounds the hypothesis that most of them came to the spawning grounds from northern waters, where the herrings grow more rapidly than in the southern portions of the North Sea. He is, he believes, in a fair way towards proving that the Firth of Forth spawning grounds are visited by shoals from Northumbrian and also from extreme northern waters.

But this is only one, and by no means the most important, part of Mr. Storrow's herring-work in 1920. He has, in fact, tackled the problem which his chief, Professor Meek, as related on p. 158 of this book, stated to be unsolved in 1916. In two respects his investigations are remarkable. In the first place they were conducted in close co-operation with men engaged in the herring industry; in the second place, and chiefly on account of that co-operation, they were made without any research vessel, and without any very great expenditure of money. He had a most able coadjutor in Mrs. Cowan, and each colleague managed to get through enough detailed and monotonous work to stagger any layman. The whole year's operations are described in the reports of the Dove Marine Laboratory (New Series, IX) for the year ending 30th June 1920. The report bristles with technicalities which might well baulk the 'lay' student. For instance, Mr. Storrow tells us that some herrings " contranatated (sic) from the east coast to the waters of the Orkney and Shetland Islands'. The astonishing verb merely means that the fish swim against a current. But the layman must remember that this paper is written not for him, but for Mr. Storrow's brother naturalists. It well repays laborious study in its present form. It will be of great value to the industry when it is translated, on the lines of Dr. Hjort's 'popular' papers, into language which fishermen can under. stand. Space does not admit of more than a very brief notice here.

\section{Mr. Storrow's Methods in 1920}

Mr. Storrow decided in 1919 that he would obtain samples from as many shoals of herrings as possible, in order to discover 
the composition of the shoals 'after such a period of comparative rest as that produced by the war'. He wrote to the Editor of the Fish Trades Gazette, who put him into communication with business men in Stornoway, Lerwick, Wick, Peterhead, Scarborough, Grimsby, and Great Yarmouth. Mr. Storrow and Mrs. Cowan were, of course, already as well known on the quay at North Shields as any owner or skipper or salesman. There they needed no introductions. From each port samples of ordinary catches were obtained. In each case a note was made of the date on which the sample was caught, of the bearings of the ground on which the 'shot' was made, of the total catch of which the sample formed a portion, and of the number of fish examined, in the following form :

$\begin{array}{ccccc}\text { Port. } & \begin{array}{c}\text { Date of } \\ \text { capture. }\end{array} & \begin{array}{c}\text { Origin. } \\ \text { Stornoway }\end{array} & \begin{array}{c}\text { Catch. } \\ \text { 27th May 1919 }\end{array} & \begin{array}{c}\text { Number } \\ \text { 20xamined. }\end{array} \\ \text { of Lew north of Butt } & 25 \text { crans } & 226 \\ \text { "10th Feb. 1920 } & \begin{array}{c}\text { Off Tiumpan Head } \\ \text { 10 }\end{array} & 10, & 212\end{array}$

Each sample consisted of a quarter of a cran of herrings, taken without selection from the eatch, very carefully packed, and sent to Cullercoats. 'By the examination of samples taken at the beginning and about the middle of the summer fishery, of full or spawning fish, and also of spent fish, it was hoped to get sufficient evidence to show if there was any connexion between the summer shoals and the shoals of spring spawners which it was intended to sample in the early part of 1920 .'

The two indomitable investigators examined 6,848 herrings. For each fish they recorded the length, the sex, the state of the reproductive organs, and the number of winter rings on the scales; the yearly growth, as recorded on the scales, was also calculated. But the age of the fish is not given, nor do they commit themselves to an opinion as to the season (spring or autumn) in which it was born.

The first part of the report consists of six pages devoted to a detailed and very excellent review of the grounds fished on the west coast of Scotland, in the Minch, to the north-westward of the Lewis, the north coast of Scotland, round the Orkneys, round Fair Isle, round Shetland, and offshore from the Cromarty Firth and Peterhead. Information, furnished by the leading men in the herring trade, is given as to when and where maiden fish, full fish, ripe fish, and spent fish are caught in each of these distant grounds, and more than one case is cited in which herrings have deserted certain waters or appeared unexpectedly in others. In this connexion $\mathrm{Mr}$. Storrow was told by 
the trade of herring-shoals which spawned in spring all the way from the north-west of Shetland to the Butt of Lewis. It may therefore be necessary to modify the theory that 'Shetland" herrings are autumn spawners (p. 163).

\section{Age}

Mr. Storrow has long ago convinced himself that it is difficult to distinguish spring spawned herrings from the autumn broods. He never attempts to decide that a particular fish was hatched in a particular year, and contents himself with recording the number of rings on the scales. In the samples from the summer catches in 1919 and 1920 he found a very large proportion of 'three-ringers' -52 per cent., for instance, at Peterhead, 69 per cent. at North Shields, 51 per cent. at Scarborough, and 37 per cent. at Stornoway. Some of these three-ringers, he tells us, were 'spring' fish-and these were three and a half years old when they were caught; others were 'autumn' fish and four years old. In fact, of the three-ringed herrings caught from Wick to Scarborough, some were hatched in the autumn of 1915, others in the spring of 1916 . It will be interesting to see whether a large proportion of the north-east coast herrings in 1921 are four-ringers.

\section{Maturity ${ }^{1}$}

Storrow's discoveries as to maturity are most important. Some of the spawners, both in spring and autumn, from Stornoway, Peterhead, Scarborough, and Yarmouth were 'tworingers' only, that is to say, fish which were either two and a half or three years old. On the other hand, he has found maiden fish which had not yet started spawning as follows:

\section{From Stornoway and Lerwick . • . 6-ringers}

From Wick, Peterhead, and North Shields . 5-ringers and 4-ringers.

There is nothing surprising in this. As Storrow points out, cock-salmon may spawn even before they go to sea for the first time, while other salmon may spend four or five years at sea before returning to fresh water to breed. But he has made it clear that individual sea animals of the same species, unlike land animals, do not all become capable of reproducing their kind at even approximately the same age. And this is another good illustration of the wisdom of Hjort when he warns us against applying the methods of landsmen to the 'vital statistics' of the sea.

Why do some herrings contract infant marriages, while

1 Dahl has found that ' herrings spawn from the third to the fourteenth year, the majority between four and eight years old' (Depths of Occan, p. 766). 
others are still bachelors and spinsters in austere middle age? When we can answer that question-and the answer is assuredly discoverable-we may be able to claim that we know something about the life-histories of herrings. The writer has more than once heard vain boasts that we know 'all about' their lifehistories, and these were made sometimes by people who should have known better.

\section{Growth}

Mrs. Cowan has calculated from the scales the length which each of the 6,848 fish attained at the end of each year of its growth. The results are tabulated in detail. Two examples only can here be given. One sample was landed at Stornoway on the 22nd July 1919 ; 86 fish were examined. In their first year the smallest had grown to $2 \cdot 3$ inches, the largest to just under 6 inches. But no less than 65 of the fish were from 4 to $5 \frac{1}{2}$ inches long, and 24 were 5 inches.

Two days later 173 fish were landed for examination at North Shields; of these 127 were from $2 \frac{1}{2}$ to 4 inches long, and 95 were 3 to $3 \frac{1}{2}$ inches, while only seven were 5 inches long. At Peterhead and Wick most of the fish caught in the same month had grown in their first year 3 to 4 inches; at Scarborough they were $2 \frac{1}{2}$ to 3 inches.

At this point the writer would state a problem. Suppose two herrings, $A$ and $B$, to be hatched in the same brood in October. By the following October, when the first winter ring appears on their scales, A is 3 inches long, B 5 inches. The big fish will, of course, have bigger scales than the smaller one. But suppose them each to survive to their fifth winter ; remove their scales ; and compare them with the scales of two herring (X and $\mathrm{Y}$ ) known to have been hatched in the February before the birth of $\mathrm{A}$ and $\mathrm{B}$. Will the scales of $\mathrm{A}$ and $\mathrm{B}$ be of a type different to the general type of those of $\mathrm{X}$ and $\mathrm{Y}$ ? Will they, in fact, have a relatively larger centre than the scales of the spring herrings ? Obviously the unknown quantity is not the actual size of the scales inside the first winter ring, but the proportion of the centre to the whole scale in the third, fourth, and subsequent years. The writer makes no attempt to solve the problem. The scales of spring herrings either exhibit a different type to those of autumn herrings or they do not. In the former case Hjort is correct in saying that spring-spawned and autumn-spawned herring can be distinguished from each other all through life. In the latter case Storrow is right in refusing to differentiate between them. Both theories cannot be right. It is for marine science to decide between them. 
The writer in September 1909 found brown trout ranging from 6 inches to $1 \frac{1}{2}$ inch in length amongst a brood hatched in the spring from a single batch of eggs under identical conditions in India. He has no difficulty at all therefore in believing that herrings of the same brood might easily exhibit similar variations in a similar period. For eleven years he has doubted whether the size of any lind of fish is per se a reliable indication of its age.

\section{The Composition of the Herring Shoals}

Storrow considers that the summer feeding-shoals are made up of young herrings which are born both in spring and in the autumn; he does not believe that spring spawners always produce fry which will inevitably themselves spawn in the spring, or that the young of fish which have spawned in the autumn will inevitably spawn in the autumn. He can find, in fact, no racial difference between spring and autumn spawners. As to growth after the first year he shows that spring spawners are no longer than autumn spawners at the end of the second year, but by the end of the third year some of them have outgrown the autumn fish, and this difference gets more and more marked with age until in their fifth year spring fish grow better than autumn fish in their sixth year. All this is apparently very much in line with Hjort's views. If there really is a better chance of long life for a herring born in the spring than for one born in the autumn, what is the reason? Until we know we do not understand the life-history.

\section{Some General Conclusions}

Storrow shows that herrings may drift in the larval stage from the north coast of Sutherland, and even from the north of the Lewis, right along the east coast of Scotland into the North Sea. These fish form feeding-shoals in the North Sea, and some of them will join shoals of autumn-spawning herrings, whose young will, in their turn, drift south as far as the Wash, and form other shoals. Some young herrings from the Wash, he thinks, may join the most northerly of the East Anglian shoals. If all this is correct, there is a close family relationship between all the herrings caught by British boats, as fishermen always maintain.

Storrow's main theme, however, is 'that the wealth of our summer fishery depends upon the young fish, the predominant year class of which has three rings, and that these young fish arise from both spring- and autumn-spawning shoals. With the 
exception of the Firth of Forth, the chief spawning grounds for spring spawners are in the waters to the north of Scotland, about the Shetlands, the Orkneys, the north coast of Sutherland, the Butt of Lewis, and possibly other localities, not frequently fished, such as Sule Skerry.'

His conclusions may be right or wrong. It is possible that his unscientific interpreter has misunderstood them! But right or wrong the value of his work remains. For he has shown that most interesting lines of research can be followed up when Science collaborates with Industry, and that such collaboration reduces the cost to a minimum. Meanwhile he regards his work on the age and growth of fishes as spade work which may one day enable science to tell herring-fishers whether they should expect a good or bad season. He has well earned the gratitude of the whole Herring Industry.

\section{Scottish Fishermen on the Herring}

Mr. E. W. H. Brander, of the Scottish Steam Drifters' Association, has kindly supplied the following information as to the fishermen's herring lore. He writes that fishermen are very emphatic in the information they give, though when crossexamined they can seldom give explanations.

\section{Races}

The Scottish fishermen distinguish two broad races- the Atlantic Herring and the North Sea Herring, the first being found west of the Hebrides and west of the Shetlands and Orkneys, and the latter east of the Shetlands and Orkneys and in the North Sea. They also recognize various local races such as the Loch Fyne Herring and the Ninch Herring-the latter a very large fish. They are also convinced that herrings taken in deep waters off the east coast are generally longer, and coarser grained, and less fat than herrings caught on the shallower banks.

\section{Shoals}

The 'shoals' vary in size from a square mile to fifteen square miles. They think that each shoal keeps to its own area, which they put at about $1^{\circ}$ of latitude. They are convinced that herrings spawned in our northern waters are never found in the southern portion of the North Sea, and that the southern fish never go north. When a shoal has spawned, they say, it will always be found within the next twenty-four hours about ten miles south-east of the spawning ground.

The shoals, according to the fishermen, lieep to certain 
distinct stretches of coastal waters, one east of the Shetlands and Orkneys and in the Pentland Firth: another off Wick and the east coast of Scotland ; another off Northumberland; and the fourth off the coast of East Anglia. They maintain that the herrings caught by the Norwegians are exactly the same as those taken by our own boats, with the exception of Fjord herrings, which they believe to be a separate race. Four causes are believed to make the shoals swim at low levels. They are always comparatively leep in the water when the sea is very calm, when the fish are very young, when the weather is cold,1 and when they are gravid with roe and sluggish in their movements. Spent fish, on the other hand, are always more lively and are found at the surface. Of course, when a drifter man speaks of herrings being deep in the water he does not mean 'deep' in the sense that a trawler man would.

Now, some or all of this herring lore may be unscientific and based on unsystematic observations. It may be that naturalists could correct the fisherman's facts where he has misapprehended them or his deductions from facts which he has correctly observed. But by personal intercourse and discussion with naturalists, and in no other way, will fishermen be taught to think correctly and observe correctly-and it is idle to suppose that their observations could not be of great use to men of science. Some of them, as we have seen, have already been confirmed by the researches of the past. Even when it is encrusted with superstition, fisher-lore may be of great assistance to research workers, just as folklore frequently helps the archaeologist. It is just this mutual discussion and personal demonstration which has been lacking in the past. Naturalists may correct and edify each other by 'publishing results' of their researches in scientific journals. Not thus will they ever reach the men whose livelihood may be affected by their work.

1 Yet Mr. Morley's trawlers could only catch herrings on the South-west Banks when the weather was very hot (see p. 117). 


\section{CHAPTER XXX}

\section{INTERNATIONAL HERRING RESEARCHES}

The International Council in 1920 considered the future of herring investigations very carefully. Dr. K. A. Andersson pointed out that the apparently ' capricious' variations in the catch were probably connected with variations in the numbers of young herrings 'born' in a particular year. The old idea was, he said, that the fish simply deserted one particular line of coast for another, so that if, for instance, the fishing fell off on the west coast of Norway it probably improved on the west coast of Sweden. Variations in the catch were, in fact, attributed to migrations of the fish, rather than to variations in the out-turn of fry.

Dr. Andersson suggested, and the Council agreed, that an endeavour should be made to prepare a statistical history of the fluctuations, like those mentioned in Chapter XXVI, which are known to have occurred in Europe.

\section{The Herring Committee of the Council}

This Committee met under the presidency of Dr. Hjort in March 1920. The chairman told the Committee of his visit to Canada in 1914, and of his discovery that in Canadian, as in European, waters, herrings from different localities differed in their rate of growth, and that in Canada also, the broods of particular years seemed to predominate season after season. His report on this subject was laid on the table. It has been published by the Canadian Government.

Dr. Einar Lea described his discoveries, which have already been detailed, as to the predominance of the 1904 and 1912 broods. And Dr. Andersson said that he had found the same broods to be predominant in Swedish waters.

The Committee resolved that in consideration of "the pressing nature of the Plaice Problem' they would, in 1920, formulate only a temporary and provisional programme of work. The Norwegian Government was to be asked to undertake the responsibility and expense of the herring researches. And that means that they will be in extremely capable hands.

The Norwegians propose to continue their examinations of the catches of 'large' and 'spring ' herrings with observations on length, weight, sex, maturity, growth, the number of 
rertebrae, and 'similar morphological characters'. They are also determined to increase their knowledge of the natural history of the Norwegian herring in its younger stages. They will analyse the fishermen's catches. They will in their new research vessel make repeated surveys of certain fjords in the north of Norway, to investigate the occurrence of herrings, their food, and the physical conditions-the temperature, for instance, of the waters. The immediate problem is this: Is there every year an influx into the fjord of a number of fish of from one to five years old in mass ? Or do only very young herrings come in each year? All the time investigations will be carried on into the 'small game' of the fjord waters, and into vital details like currents and the temperatures at different depths.

All this is satisfactory. Former chapters have shown that many similar problems remain to be worked out with regard to the herrings landed on our east coast, and that these fisheries are by far the greatest in the world. It is exasperating, at first sight, to see our own herring problems apparently shelved even temporarily. But they are not being shelved. The Norwegians - who are the 'sea-daddies' of all the world-can be relied upon always to ' think big'. They realized, long before we did, that parochialism had no place in ocean research, and they can be relied upon now, as always, to investigate the herring problem as a world problem. They, like ourselves, are hard hit by the war. Funds and trained workers are alike scarce ; and they must cut their coat according to their cloth. They will complete their knowledge of the herrings which spawn on the south-west coast of Norway. But they will regard this as a step in the unravelment of the secrets of the whole herring tribe. The knowledge they acquire of the hatching and development of their young fishes; the climatic conditions and the diet which suit them; the dangers which encompass them; the wanderings of the fry ; the impulses which make the adult fish congregate in particular places at spawning time; and the movements of the tribe in between one spawning period and another-all this information will be of incalculable use when the International Council finds means and opportunity to tackle the other ' races' of herrings. 


\title{
CHAPTER XXXI
}

\author{
THE MACKEREL
}

The European Catch, 1913

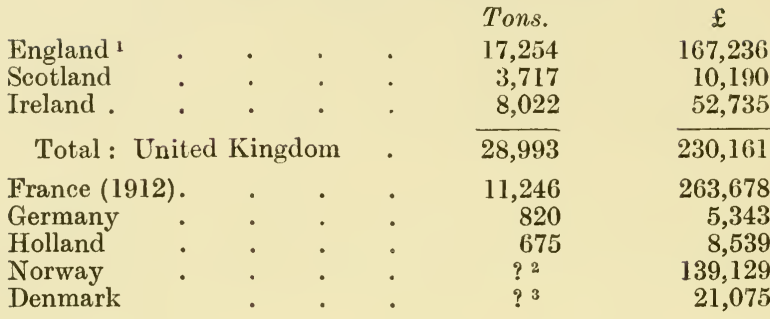

Analysis of the British Catch, 1913

In England and Wales the following ports landed the greatest quantity :

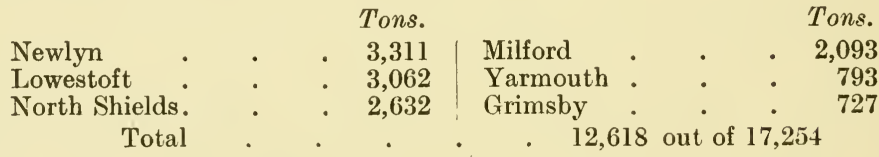

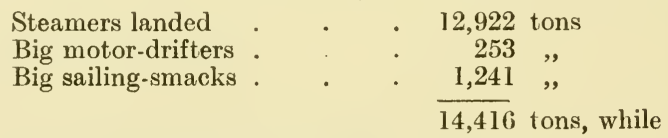

The small fisheries provided 2,838 tons.

In Scotland:

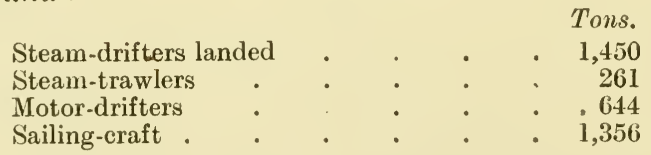

In Ireland the statisties do not admit of exact analysis on

1 In 1920 the landings were :

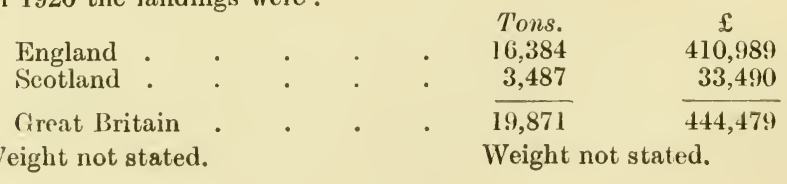


these lines, but it is stated that 171 large or 'first-class' vessels were fishing in the spring, and 771 in the autumn.

The Irish statistics are interesting. They ${ }^{\mathbf{1}}$ give 3,525 tons as caught in the spring, and 6,146 tons in the autumn-a total of 9,671 tons. But the total landed as given in Appendix No. 1 is 8,022 tons. The discrepancy of 1,650 tons or so is not explained, but is no doubt explicable.

\section{Life-History}

Hjort ${ }^{2}$ tells us that the natural history of mackerel ' has been very little investigated, and very little material was obtained during the cruise of the Michael Sars'. Allen and his colleagues at Plymouth have shown that the fish spawns earlier in southern waters than it does further north; and Orton believes that it probably breeds throughout its whole range only when the water temperature at the surface is at least $53 \cdot 6^{\circ}$ to $55.4^{\circ} \mathrm{F}$. Off the British coast the spawning season starts in May and lasts to the end of July. The mackerel shoals discharge their eggs, about one-twentieth of an inch in diameter, ${ }^{3}$ near the surface at a short distance from land; the spent fish as they spawn quit the shoals. Within forty-eight hours after fertilization, as a rule, the eggs, although they are provided with an oil globule, begin to sink; they remain suspended at midwater for a short time, and then sink to the bottom. ${ }^{4}$ At a temperature of $58^{\circ} \mathrm{F}$. the period of incubation is about six days. The average number of eggs produced by a female in America is about 40,000 . But three fish at Woodshole have been known to give an average of 144,833 eggs, and 546,000 have been taken from a $1 \frac{1}{8} \mathrm{lb}$. fish. A large fish in Casco Bay has given 200,000; and the largest of all are believed to yield probably as many as a million. Within forty-eight hours of fertilization the embryo is visible in the egg. The American fish culturists, who hatch out millions of eggs, find that, in hatching jars or hatching-boxes, many eggs die at the end of the third day. In 1898 they hatched, as a rule, less than one mackerel egg in a hundred, though in some experiments they got results as good as 75 per cent. By 1914 experience had taught them to hatch nearly 40 per cent.,for $6 \frac{1}{2}$ million eggs produced $2 \frac{1}{2}$ million fry. Whether eggs discharged in the sea are subject to like mortality is not known, but it has been noticed that the eggs of mackerel which have been a long time in the nets-as mackerel frequently are-

1 Appendix $4(a)$ and $5(a)$.

2 Depths of Ocean.

2 The average diameter is $0.047 \mathrm{inch}$, and therefore nearly 652,000 mackerel eggs go to the quart.

II anual of Fish Culture, pp. 212-13. 
have very much less vitality than those of fish stripped before they have been thus weakened.

The larvae are about one-tenth of an inch on hatching. In about four to six days the mouth appears and is open. By the ninth day the fish is about one-fifth of an inch long and the yolk is absorbed-and these five days or so probably constitute the critical period when the baby food begins to be supplemented by floating food of some kind. Dr. Lebour, in July, this year, found quite a number of mackerel fry, at a stage a little later than this, about one-fifth of an inch long, and a very large number of these contained no visible food at all. It is not clear whether they could or could not have been feeding on singlecelled $^{1}$ animals. Larger fry, apparently about three weeks old and measuring about two-fifths of an inch, have been taken off Plymouth in May 1914 ; and Atkinson has caught mackerel fry on the night of the 13th August 1913 over the Great Fisher Bank which measured nearly two inches. It is not known but is assumed that the spawning period in the North Sea is May to August, so these fish were not more than three months old. R. S. Clark obtained young mackerel $3 \frac{3}{4}$ to 4 inches long inside the stomachs of haddock and whiting trawled off the Tyne in October 1918-and these, he calculated, were probably fourteen months old. Clark concludes that the fry grow nearly two-fifths of an inch a month on the average. During the fry stage, Dr. Lebour finds, the mackerel live principally on the eggs and larvae of copepods (like Temora and Calanus) and 'water-fleas' (like Podon and Evadne), and from the time they reach three-tenths of an inch in length they start their career of depredations on other fishes by feeding on young gobies and blennies. One of half an inch contained a blenny more than half his own size.

\section{Fluctuations in the Catch}

The best account of the 'caprices' of the mackerel on a particular coast is that given by Mr. A. H. Patterson. ${ }^{2}$ In Yarmouth a big mackerel fishery was carried on, not without vicissitude, in May and June, till the ' sixties', when it suddenly ceased. Needless to say the sailing trawlers were blamed. They had 'invaded the feeding-grounds of the mackerel' and the mackerel had disappeared; the case was clear. 'Then,

1 Dr. Lebour has suggested to the writer that undigested food in the intestine of a transparent larva renders it less transparent, and therefore more conspicuous to its enemies, and that Nature may have endowed little fishes with the power of very rapid digestion in order to counteract this danger

2 Ilan and Nature in Tidal Whaters (Methuen, 1909). 


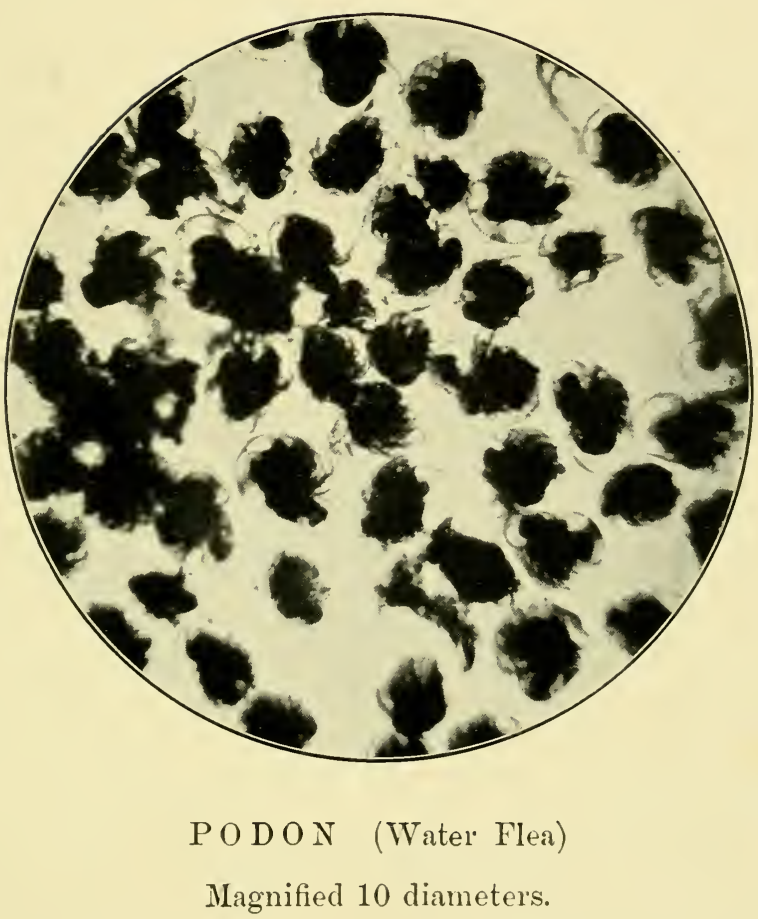

Newly hatched fish will eat Podon and another water flea called Evadne before the yolk sac has disappeared; especially turbot, soles, plaice, brill, megrims, and lemon soles. They are also eaten by young mackerel.

(Photograph by Mr. A. Scott.) 

rather disconcertingly, at the end of the 'eighties' the mackere 1 began to turn up with the herrings in September. About the same time large quantities of autumn mackerel began to appear off the Cornish coast, and the east-coast drifters for a year or two made very successful voyages after them. Then in 1904 and 1905 the fishery in Cornwall failed completely. From that time on very few east-coast drifters steamed westwards after mackerel at the end of the herring season, more especially after the French (our best customers) had placed a heavy duty on British mackerel exported to France. In 1906, without the least warning, mackerel suddenly turned up on their old haunts off Norfolk in May and June, and all hands turned out to catch them. In 1908 the glut of November mackerel was so great that in the middle of the herring harvest certain boat-owners fitted out with mackerel-nets in place of herring-nets, and one drifter caught 50,000 fish one night, while another made $£ 450$ in four nights; in several cases the drift-nets sank to the bottom with the weight of mackerel.

In the meantime the industrial revolution in the fisheries had come about, and the trawler fleet had changed from sail to steam. So events had proved that whatever might be the cause of the disappearance of the mackerel it was not, after all, due to the operations of beam-trawlers or otter-trawlers. And to this day causes of these caprices (so-called) - although one may be perfectly certain that the impulse which guides the leaders of the herring shoals is not 'caprice'-remain unknown. It can be taken for granted that the mackerel come shorewards in the spring with the object of spawning. They appear off the coast of Kerry very early in spring ; a few weeks later they are off the south-west of the Scillys, and by the beginning of Mayas we have seen-they are spawning on one part or another of the British coast. But why do they suddenly cease to visit a particular region? Or, as suddenly, return to it? Nobody knows. Yet it is important that fishermen should be told. For with coals and nets and stores at their present prices it is a desperate venture to dispatch a fleet of modern drifters on a long voyage after mackerel-say from Yarmouth to the Scillys-in the full knowledge that they may find no fish ; or on the other hand may run into a glut so enormous that the railways cannot suddenly improvise transport to deal with it; and only accurate knowledge of the conditions which attract or repel the shoals can ever turn mackerel-fishing from a rather blind gamble into a reasonable speculation.

Meanwhile old fishermen on the east coast have noted that rough weather with a good breeze which would send herrings 
'down', brings mackerel to the surface; that the big catches are generally made when the water is a greeny-white colour, with a greasy look about the surface; that the fish are then full of 'herring syle'; that the noise of a mackerel-shoal ruffling the surface is like the noise of a rain-squall; and that where the mackerel abound, there underneath them will be found skate, and cod, and ling in abundance.

\section{Mackerel Researches in the Future}

Meek tells us in his Migrations of Fish that mackerel mature at about 12 inches long, when they are three or four years old. He notices that in the last decade the catches of mackerel on the American side of the Atlantic diminished steadily while the European catch has been steadily improving.

As to the wanderings of the adult fish very little is known. The Canadians, Hind and Whitchet, and Cligny in France, seem to believe that mackerel move offshore in winter, and go down into deeper and warmer water quite close to the coast. The American, Browne Goode (on the other hand), thinks that the shoals move far out into the Atlantic in winter. This is a point which Business expects Science to clear up-and it cannot, in fact, be an insoluble problem.

But far more important from the fisherman's point of view are the fluctuations in the numbers of the mackerel which make up the shoals. If the causes of these variations could be fixed, as Science is fixing them in the case of cod and haddock and herring, we should be in a fair way towards forecasting the mackerel harvest.

We have, apparently, hardly started on this road yet. True Garstang ${ }^{1}$ showed that mackerel were abundant in the Channel in February and March of 1897, when south-westerly breezes brought in a supply of warm Atlantic water, and scaree in the same months of 1896 and 1898 , when the wind was nortli-easterly and the water cold. Allen, ${ }^{2}$ too, has shown that sunshine in February produces an abundance of diatoms, which means an abundance of copepods in May-and so a greater congregation of mackerel and good hope of a successful hatching season. But are the fluctuations in the numbers of mackerel caught due to the fact that in some years fewer eggs are hatched out than in others? Or are there sometimes abnormally small losses among the baby fish at the time they first begin to feed ? Or is there some other explanation? Science camnot, at present,

1 Journ. H. B. A., N. S., V, 1 s97 9. p. 1.

2 llbid., 1898-9, p. 235. 
answer. But it is obvious that Business should insist upon and encourage investigations into scale reading as applied to this species, into the effect of temperature upon its breeding habits along the lines laid down this year at Plymouth by Orton, and into the food of the young at the 'critical period '-the time when the baby fish first begin to feed. These inquiries, if correlated with researches into the 'small game' on which young mackerel depend, will probably produce results of immediate practical value to the fishermen-and especially to the drifter men. And the 'small game' inquiry is all-important. The Americans believe, for instance, that when mackerel have been feeding on the copepod which their fishermen call 'red feed ' or 'cayenne', they spoil very quickly after capture.

But there is no 'isolating' the mackerel problem. The shoals hunt not small game only, but the fry of the herring, and many other species. They are in their turn hunted by cod and ling and skate, and other trawl-fish. If we once arrive at the stage of prognosticating the mackerel harvest, trawlermen and long. shoremen are likely to discover from the "mackerel forecast' many things which will help them in their search for other fishes.

Mr. J. Willis Bund, in his evidence before Mr. Tennant's Committee in 1908, drew attention to Norwegian investigations on the capture of salmon in mackerel nets. "If it is a factI do not say it is-but if it is the fact that salmon feed on the young mackerel, the movements of the mackerel would regulate to some extent the movements of the salmon, and consequently, the habits of the mackerel and the salmon are interdependent.'

This piece of evidence is at least valuable as emphasizing the fundamental truths (so often obscured by silly rivalries) that the interests of all classes of fishermen are one ; and that there is no break in the chain of interdependence of all forms of life in the sea. 


\section{CHAPTER XXXII}

\section{THE SMALL GAME OF THE SEA}

\section{The Importance of Temperature}

From p. 445 of The Depths of the Ocean is reproduced HellandHansen's chart showing the distribution of temperature in the North Atlantic at a depth of 55 fathoms (100 metres). Hjort notices (p. 444) that the 'northern' forms of fishes like cod, haddock, coalfish, whiting, plaice, lemon soles, ling, and halibut, which are taken mainly in the North Sea or in waters north of the North Sea, are confined to an area north of the line which marks a temperature of $50^{\circ} \mathrm{F}$. at this depth. On both sides of the Atlantic these northern forms live in water between $35^{\circ} \mathrm{F}$. and $50^{\circ} \mathrm{F}$. at 55 fathoms, and 'the maximum frequency of the species' occurs between $42 \cdot 8^{\circ} \mathrm{F}$. and $46 \cdot 4^{\circ} \mathrm{F}$., but south of the $50^{\circ} \mathrm{F}$. line, which touches the extreme north-west coast of Ireland, and divides two areas known to marine naturalists respectively as 'north-west' and 'south-west of the British Islands', the northern fish do not occur (see map, Fig. 20).

But the $50^{\circ} \mathrm{F}$. line at 55 fathoms is not by any means the northern frontier of the 'southern' tribes. Hjort 'defines the 'southern' species as being fishes 'which are chiefly derived from the Atlantic, notwithstanding the fact that little fishing is carried on in this area ', and includes hake, soles, gurnards, bream, monks, skate, and rays. From preceding chapters it is clear that these tribes at certain times of year invade the territory of the northern species. More especially in the southern North Sea, on the grounds west of our islands, in the Kattegat, and along the Skagerrak coast-where the summer surface temperature of the sea runs high-but also in other grounds like the Minch, 'southern' and 'northern' fish are caught side by side. The wide range of the southern species is, Hjort thinks, "probably due to the fact that the water layers in the North Atlantic run north.' Thus the southern species in their youngest stages drift northwards, and "may as a consequence pass their youth very far from the localities where they were born'.

Hjort's investigations showed him that the southern commercial fishes like hake did not occur below the 300 -fathom line. Hake, ling, and bream are trawled by commercial vessels at 200 and 300 fathoms both off the west of Ireland and off Ioroceo. They are caught, in fact, in the deepest waters which 
they inhabit. The temperature at 300 fathoms off the west of Ireland is $50^{\circ} \mathrm{F}$.- ' the temperature which marks the southern limits of the northern forms' in those waters. So 'vertically as well as horizontally the fauna termed by me the southern one appears to exist within the same limits of temperature. The different species appear to be at liberty to move within

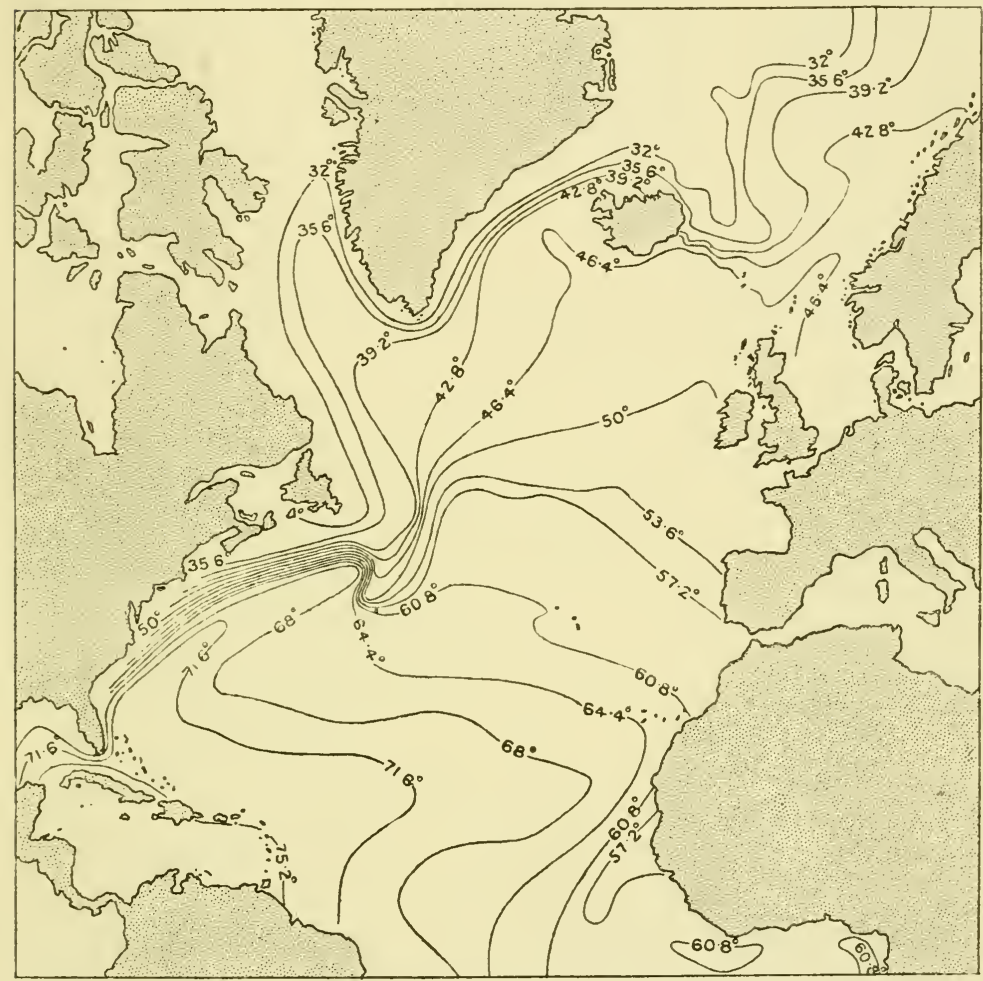

Fig. 20.-The temperature of the North Atlantic at a depth of $\tilde{5} 5$ fathoms. (Drawn by Helland-Hansen and reproduced from The Depths of Ocean by permission.) Note : the $50^{\circ}$ line in this map is the southern boundary of the northern marine animals on both sides of the Atlantic. (After Hjort.)

these limits and to be independent of depth. Thus there are many observations showing that the southern species occur in deeper waters on the Atlantic slope than they do in the North Sea. This is easy to understand because in the North Sea only the shallow upper layers are affected by high temperatures. . . . On the shallow coast banks and on the Dogger 
Bank the temperature at the bottom rises to at least $12^{\circ}$ $\left(55 \cdot 6^{\circ} \mathrm{F}\right.$.) in the summer season. The sole may thus find here temperatures similar to those off the Atlantic coast of Europe, though in somewhat shallower water.'

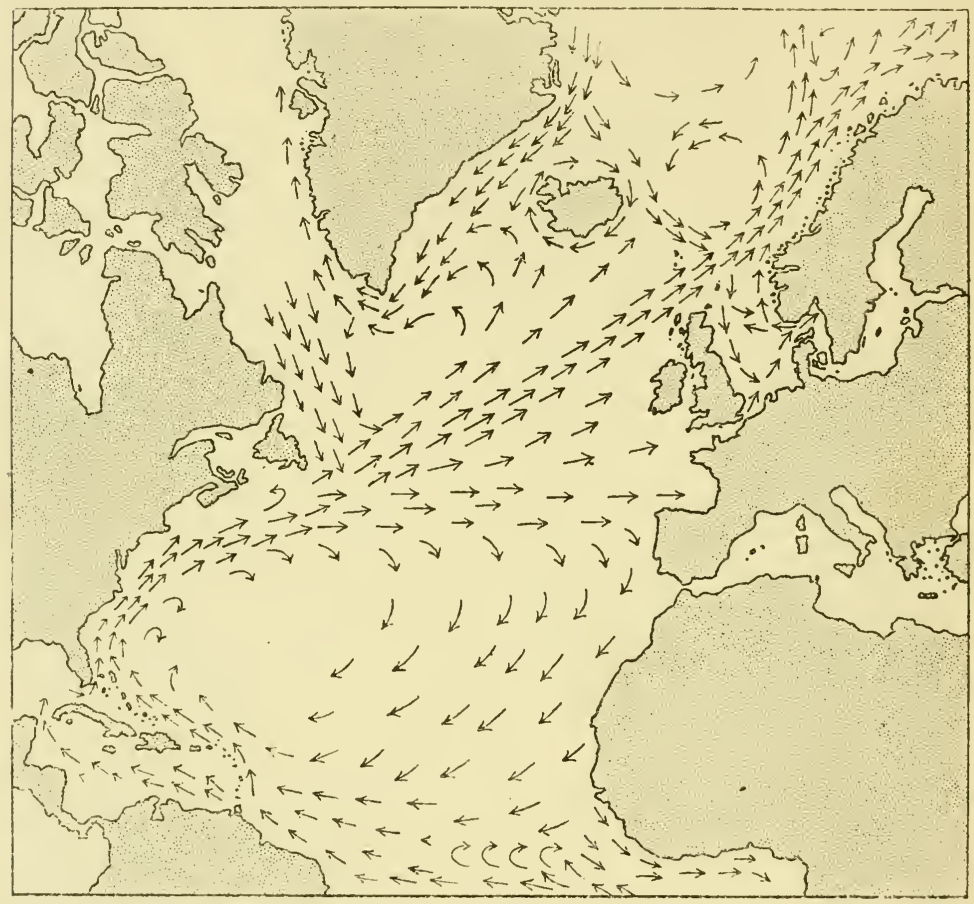

Fia. 21.-Currents of the North Atlantic. After Schmidt's 'Valdivia' Report and Helland-Hansen and Nansen's memoir on The Norwegian Sea. (From The Depths of Ocean. By permission of Messis. Maemillan.) ${ }^{1}$

Below 40 metres ( 22 fathoms) the summer temperature is not much higher than the temperature during winter, viz. between

1 The course of the currents here shown is, of course, only the average direction. The Gulf Stream, for instance, is not a body of warm water moving steadily across the North Atlantie. Its flow resembles 'bands of current" forming huge swirls 'whose strength and direction vary almost daily'. The Michael Sars in June 1910 found a strong set to the south-west about 280 miles to the southward of Newfoundland. The eable ship Podbirlski found a similar flow in the same direction in May 1902. And on our own side of the Atlantic the research trawler Nicholas Dean experienced a strong south-westerly set over the Lousy Bank ( $60^{\circ} 19^{\prime} \mathrm{N}$. and $12^{\circ} 36^{\prime}$ W. $)$ in August 1920. These instances in which the Gulf Stream was found to be flowing south-west instead of north-east illustrate Helland-Hansen's warning that we know very little indeed about the variations of the ocean currents. (Depths of Ocean, pp. 299 and 300 .) 
$42.8^{\circ} \mathrm{F}$. and $44 \cdot 6^{\circ} \mathrm{F}$. Temperature, then, plays a predominant part in determining the distribution of the fishes. It is interesting to note that it is a no less important factor in the distribution of the minute organisms on which the nutrition of fish depends.

\section{1)istribution of the Small Game}

In Chapter VIII of Depths of the Ocean Hjort has a wealth of interesting information on the "small game" which lives on the sea-bottom. It appears that in the southern portion of the North Sea (south of the Dogger) the summer temperature of tbe water rises to $55^{\circ} \mathrm{F}$. or $59^{\circ} \mathrm{F}$. at depths down to 22 to 27 fathoms ; in winter it is cooled down to $39^{\circ} \mathrm{F}$. or $41^{\circ} \mathrm{F}$. The bottom animals on these shallows accordingly consist of two

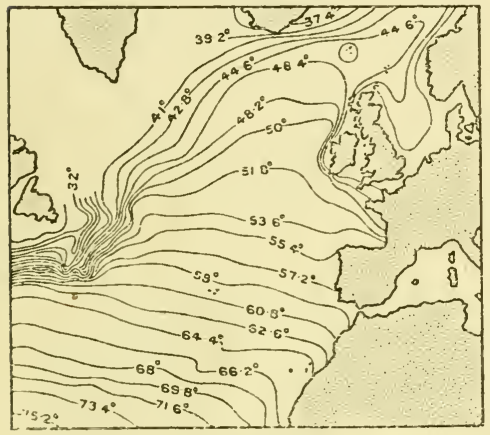

February.

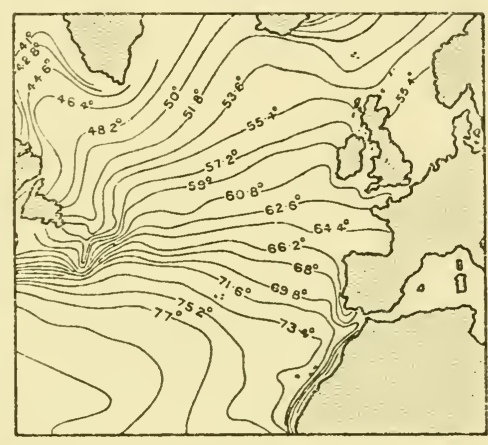

August.

Fit 22.-Surface temperature of the North Atlantic.

contingents-the northern animals who are "capable of adapting themselves to variations of temperature', and a 'special contingent that has wandered in through the English Channel and requires high temperatures for at any rate part of the year. Most of these latter forms are limited to the southernmost portion, though a few follow the coasts towards the north, penetrating on the east side even to the Skagerrak, and on the west side to the coasts of Northumberland or perhaps still further, but avoiding the deeper parts of the central area'

The whole of the northern part of the North Sea is covered with Atlantic water. On its most northerly banks, where the depth is over 54 fathoms, that is to say, on banks like the 'Witch Ground' which is included in our ' $\mathrm{F} 1$ ' area-the waters are warmer than in the central parts. Here are found again two contingents of animals. Firstly the "special southern 
deep-water forms that have wandered in past shetland, and only very rarely get so far as the coast of Norway or the
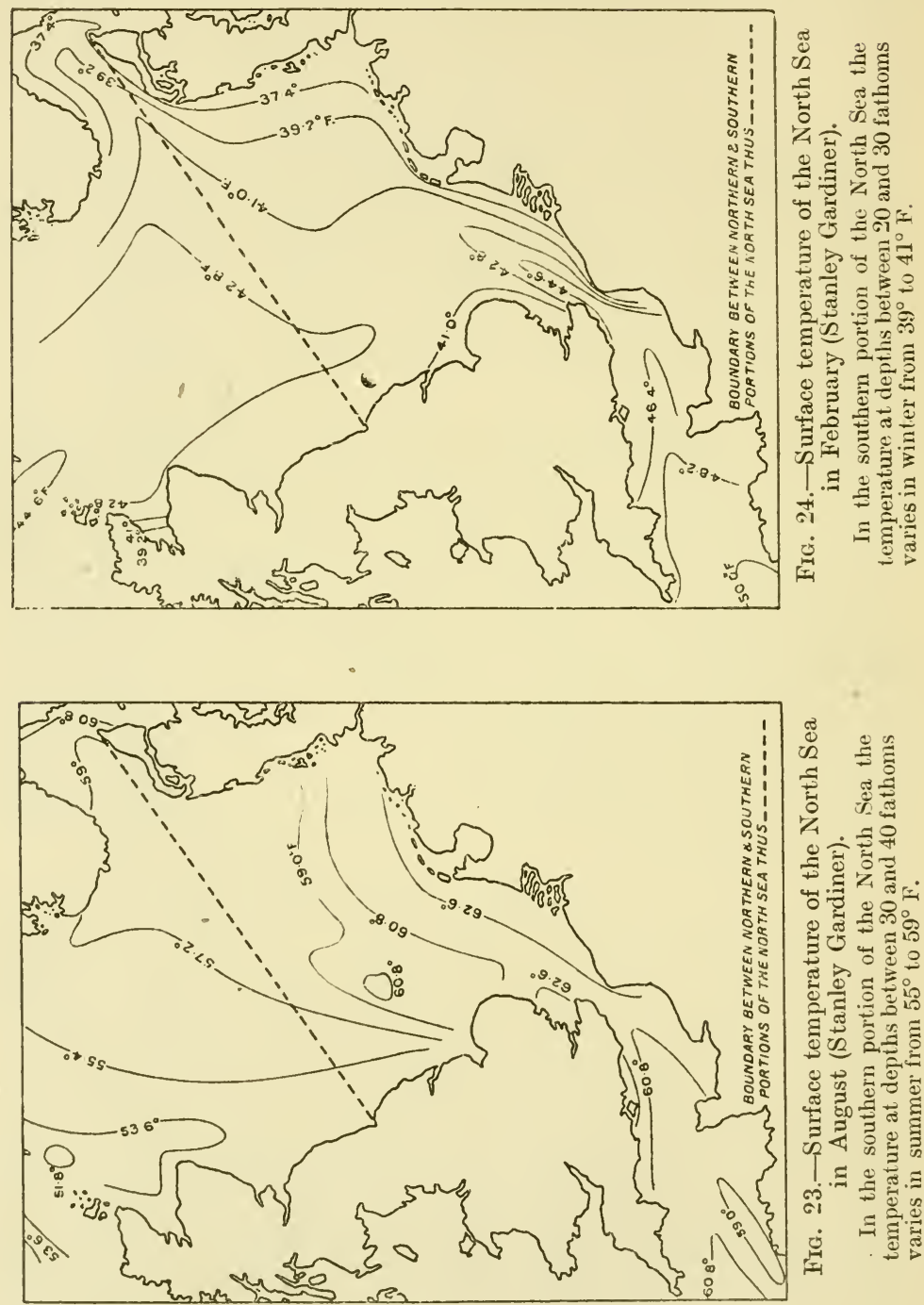

Skagerrak; and secondly animals which 'may either have arrived originally from the south, or else are true natives, nowadays at any rate widely distributed throughout the northern 
seas. In the central-and coldest-portions of this area are animals which for the most part are found also all round the coasts; but numbers of coastal forms-and especially the shallow-water forms-do not inhabit the central banks at all'.

On the western edge of the Shetland Banks the Michael Sars found a temperature of over $48^{\circ} \mathrm{F}$. at a depth of 164 fathoms. This is a good deal warmer than the southern North Sea in winter, and the high temperature is probably due to the Gulf Stream. Here, in deep water, British investigators had located certain 'southern' animals from the Mediterranean and the Atlantic as early as 1868. Some of these animals find their way along the east coast of Scotland and England, but do not spread eastwards. These 'southern' forms, although they occur, do not, of course, preponderate off Shetland. Most of the animals here are, in fact, ' northern' forms identical with those found among the islands off the west coast of Norway.

\section{CORRIGENDUM.}

P. I9I, 1. 40.

This sentence should run :- ' turning north-east just before reaching the Dogger Bank, and afterwards sweeping northwards on reaching the edge of the Norwegian depression.'

\section{Ocean Research.}

Even this very condensed summary will be enough to suggest to any trawlerman that fishes are distributed very much as is the 'small game', and to suggest reasons for certain puzzles like the appearance of hake in the North Sea. As Hjort puts it: "Helland-Hansen has shown that in the deeper layers there is a circular current of Atlantic water in the North Sea, a branch of the Gulf Stream following the east coast of Scotland, turning north-east just before reaching the edge of the Norwegian depression.' The latter is, in parenthesis, the deep narrow trench more than 110 fathoms below the surface which runs parallel to the south-west Norwegian coast from the latitude of Stat to the Skagerrak. 'As a result the periphery of the central portion of the North Sea is bathed by water of much the 
deep-water forms that have wandered in past shetland, and only very rarely get so far as the coast of Norway or the
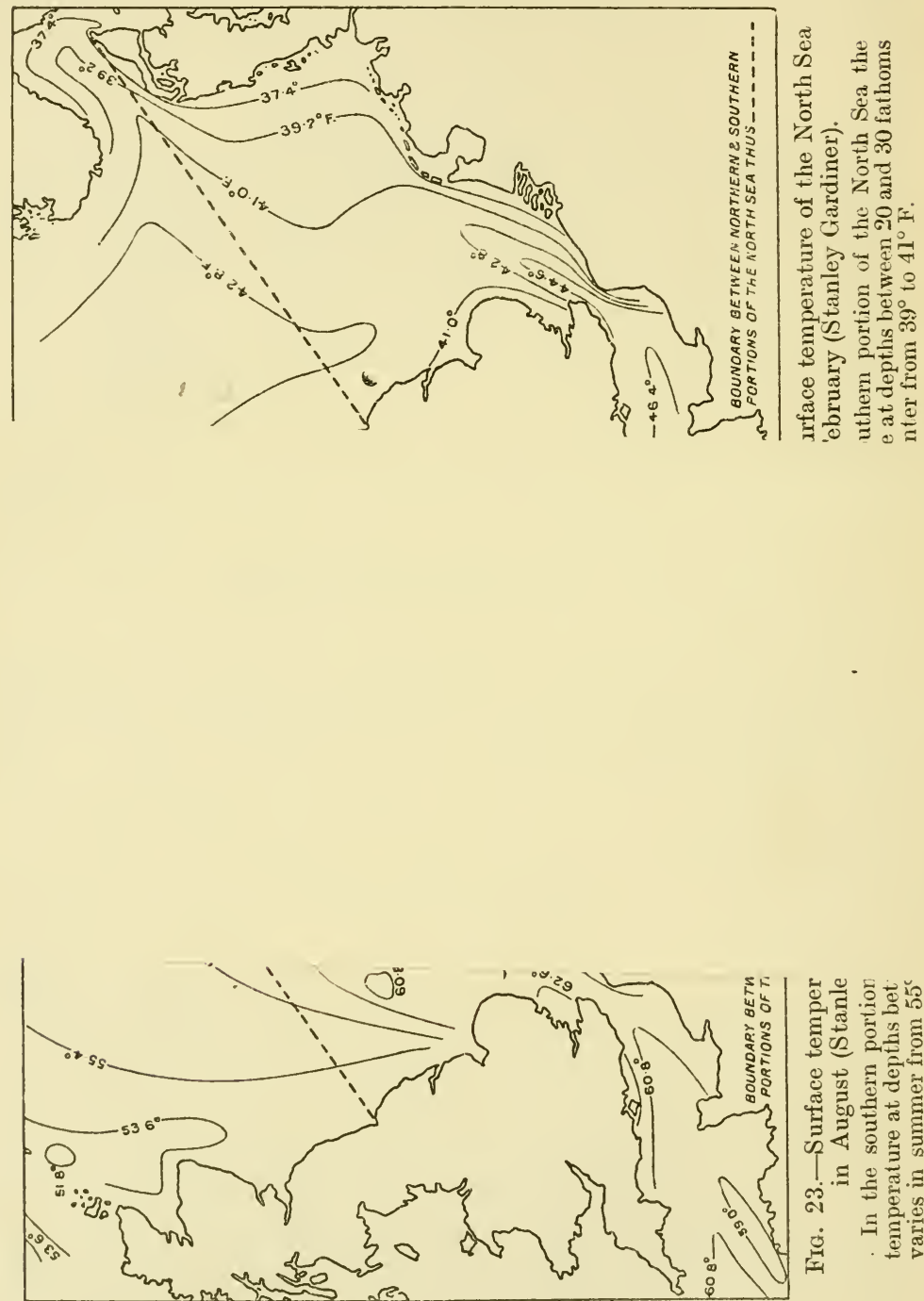

Skagerrak; and secondly animals which "may either have arrived originally from the south, or else are true natives, nowadays at any rate widely distributed throughout the northern 
seas. In the central-and coldest-portions of this area are animals which for the most part are found also all round the coasts; but numbers of coastal forms-and especially the shallow-water forms-do not inhabit the central banks at all'.

On the western edge of the Shetland Banks the Michael Sars found a temperature of over $48^{\circ} \mathrm{F}$. at a depth of 164 fathoms. This is a good deal warmer than the southern North Sea in winter, and the high temperature is probably due to the Gulf Stream. Here, in deep water, British investigators had located certain 'southern' animals from the Mediterranean and the Atlantic as early as 1868 . Some of these animals find their way along the east coast of Scotland and England, but do not spread eastwards. These 'southern' forms, although they occur, do not, of course, preponderate off Shetland. Most of the animals here are, in fact, 'northern' forms identical with those found among the islands off the west coast of Norway.

On the Faeroe Bank in 1902, at 54 to 164 fathoms, the Michael Sars found the whole bottom covered with white mussel-shells, with a few living specimens among them. Here in the middle of August the temperature was as high as $48 \cdot 8^{\circ} \mathrm{F}$. Mussels are, of course, normally shallow-water animals, and the Faeroe temperature was very nearly the same as that on the Norwegian shallows (where these mussels principally flourish) in August.

It is impossible to pursue this most fascinating line of inquiry further here. But when it is remembered that these bottom animals are (many of them) fixed to the bottom, and that very few of them can wander far down a current except when they are in their earliest stages of development; when, moreover, we see, as we have done, that the larvae of some of them in the free-swimming stages form the food of the baby fishes during the most critical period of their existence, the 'importance' of a knowledge of their life-history becomes at once evident.

Even this very condensed summary will be enough to suggest to any trawlerman that fishes are listributed very much as is the 'small game', and to suggest reasons for certain puzzles like the appearance of hake in the North Sea. As Hjort puts it : "Helland-Hansen has shown that in the deeper layers there is a circular current of Atlantic water in the North Sea, a branch of the Gulf Stream following the east coast of Scotland, turning north-east just before reaching the edge of the Norwegian depression.' The latter is, in parenthesis, the deep narrow trench more than 110 fathoms below the surface which runs parallel to the south-west Norwegian coast from the latitude of Stat to the Skagerrak. 'As a result the periphery of the central portion of the North Sea is bathed by water of much the 
same composition as the warmer water of the Atlantic, enclosing an area covered by more stagnant and on the whole colder water, having a fauna of its own.' And he adds (cautiously) 'repeated investigations will be necessary to ascertain whether' this faunal dissimilarity observed in 1904 is permanent or not.'

Had British fishermen known by 1905 that Norse investigators were carrying on work which thus throws so much light upon one of the subjects more discussed than any other in trawling circles-the distribution of fish-shoals and the effect of temperature upon it -it is quite certain that Business and Science would have understood one another many years ago.

\section{The 'Small Game' as Baby Food}

In the chapters which have been written an attempt has been made to emphasize the vital need for an accurate knowledge of the diet of young fishes at the stage when they first begin to take food other than that which is contained in their yolksacs. A very great deal of knowledge has been accumulated on this subject - and the honour is due to Dr. Marie V. Lebour, of the Plymouth Laboratory. Her work has, of course, according to the splendid tradition of the Marine Biological Association, been reported step by step as it proceeded, but these reports are printed for the information of her scientific colleagues, and are not always to be understood by the layman. She will therefore forgive any shortcomings which may occur in the attempt at a popular sketch of her work which the writer now essays for the information of his brother laymen. Her method is as follows. The young fish are caught, by the research vessel Oithona, either in the tow-nets, or in one of the young-fish trawls - the latter being most ingenious otter trawls with a mesh as small as one-twelfth of an inch. On their arrival at the laboratory Dr. Lebour dissects out the alimentary canals and examines the food which is in them. The smallest turbot thus dissected was 6 millimetres long. That is to say :

That is what is meant by the statement in Chapter I, p. 15, that the world of these little fishes was a world which could be explained only with the aid of a microscope.

Dr. Lebour tells us that few fish are vegetarians; and as a rule only the very youngest fish eat diatoms. Very young herring and plaice and other fish, however, do undoubtedly eat them, and we have seen in Chapter XVII that their absence or presence in the sea at the right time probably makes all the 


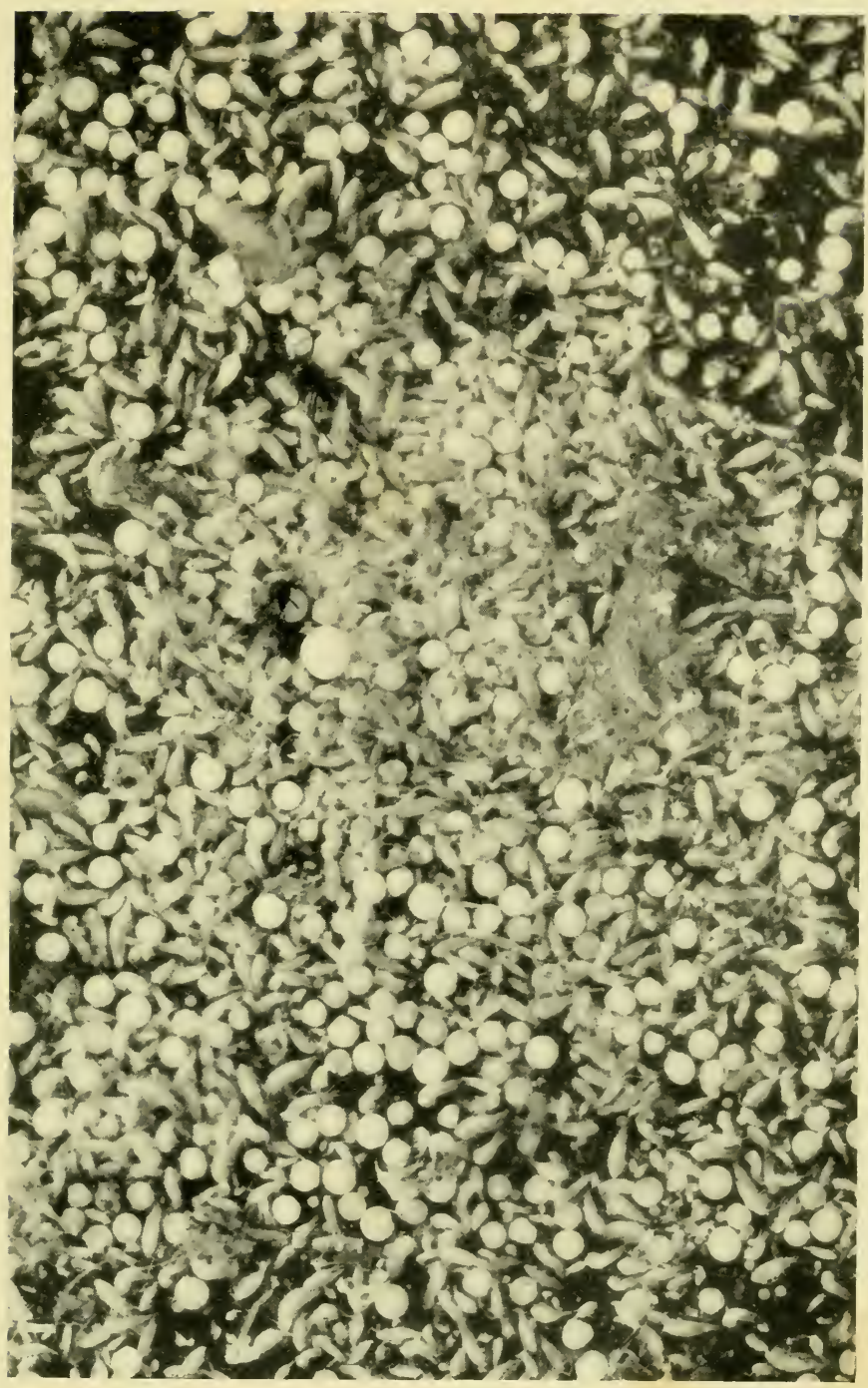

PLANKTON CONTAINING FISH EGGS (Photograph by Mr. A. Scott.) Magnified about 5 diameters. 

difference between wholesale destruction of the brood and an abnormally large hatch of herring, cod, and haddock. A newly hatched plaice in an aquarium has been observed feeding on a diatomic plant called Navicula which was growing at the bottom of the glass tank.

The diatoms are, however, equally important because they undoubtedly furnish the food of the 'small game' on which fish feed. And Dr. Luebour has proved that little herring and other babies take to eating the larvae of certain molluses and small crustaceans before the yolk has all gone. It is here possible only to compile quite a few notes about these small animals.

By far the greater part of the food of very young fish consists of the larvae of certain crustacea called Copepods or 'Oar feet'. These-in water north of the Bay of Biscay-consist of between forty and fifty different species. They are never more than a few millimetres in length, and they live on the small plants which float at the surface. The illustration (Plate XX) shows a typical form which is eaten largely by young cod and also by 'finner' whales. This particular species, according to Gran and Damas, breeds in the spring above the Continental slopes of the Norwegian Sea. The young go through five larval stages, and only assume the shape of the adult in the sixth. The same men who have worked out the life-history of the cod have worked out that of Calanus, and they have been equally enthusiastic about each. This- the writer has heard it over and over again-has been accounted unto them for unrighteousness. It is almost incredible that such an ignorant view should be so generally held in 1920, but has Science explained ?

The Calani, Hjort tells us, "constitute the main nourishment upon which, more or less directly, the animal life of the Norwegian Sea depends;' they are supposed each to eat almost one-tenth of their own weight in microscopic floating plants every day. Off Plymouth, at any rate, Dr. Lebour is convinced that copepods form the chief food of larval and post. larval fish ; and by far the greater number of fish eat the species which is depicted in Plate XX either in one of its larval stages or in the adult stage-and three other species whose names are in the foot-note. ${ }^{\mathbf{1}}$ In the Norwegian Sea Calanus practically dis. appears in winter, but off Plymouth the four species named

\footnotetext{
1 Pseudocalanus elongatus, Acartia clausi, Temora longicornis. The most important copepod in the North-east Atlantic is the open water species Calanus finmarchicus. But Temora is a favourite food of some fish. For instance, in January 1872 Kiel harbour was crammed with herrings for three weeks, and each herring was crammed with a compact pink bolus consisting of about 60,000 Temorae.
} 
occur practically all the year round, and are most abundant in spring and summer just as most of the young fishes put in an appearance. One young hake, 6 millimetres long $[-]$ contained six copepod larvae-this gives some idea of their size-and Dr. Lebour has detected eggs probably belonging to these copepods inside young whiting, mackerel, lemon soles, and brill! The eggs are 0.06 millimetre-say one four-hundredth of an inch in diameter.

After the copepods, in order of popularity among baby fishes, come the Cladocera or 'water fleas'. These are depicted in Fig. 25. They have two shells, a large pair of antennae.which they use as oars, and one large eye. They are only common off Plymouth in the summer, and are then eagerly taken by the very youngest fish.
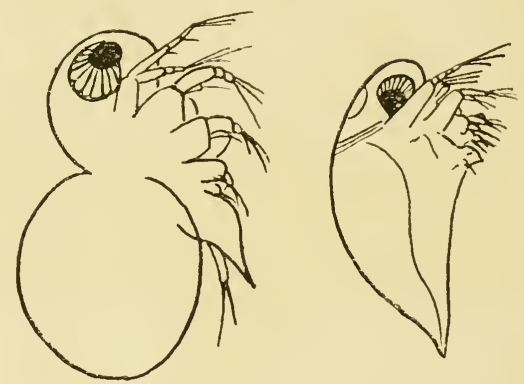

Fig. 25.-CLADOCERA or Water Flcas ${ }^{1}$

a. Podon, $1 \mathrm{~mm}$.

b. Evadne $0.9 \mathrm{~mm}$.

Drawn by Dr. M. V. Lebour. These water fleas are eaten freely by the newly hatched turbot, soles, megrim, plaice, brill, and lemon soles.

Third in importance come the young barnacles. These are not, like their parents, attached to rocks or to the bottom, but swim about freely. Plate XIX shows them at two different stages of their 'free-swimming' life. The barnacle really lives in the tidal area near high-water mark. It has found its waythanks to its larvae-down stream of the currents to the Murman coast; but is never found in Spitsbergen. Yet it can survive after it has been encased in ice for a considerable time. The larvae appear off Plymouth in numbers in winter and early spring; and again in July and August.

The mollusca also feed young fish in their very earliest stages,

1 Copepods and water fleas both belong to the order 'Fntomostraca' or crustaceans with shells cut in two. Nearly all of them are one-eyed, and Calanus finmarchicus used to he called Monoculus finmarchicus in 1765. 


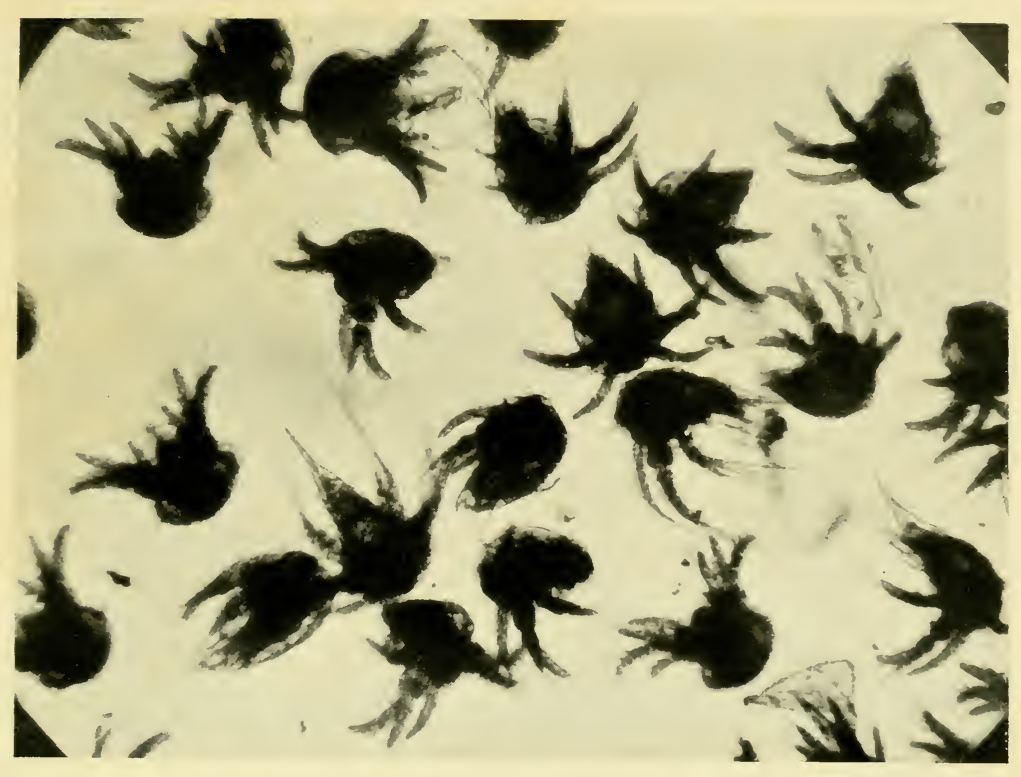

FIRST STAGE OF BARNACLE Magnified 50 diameter's.

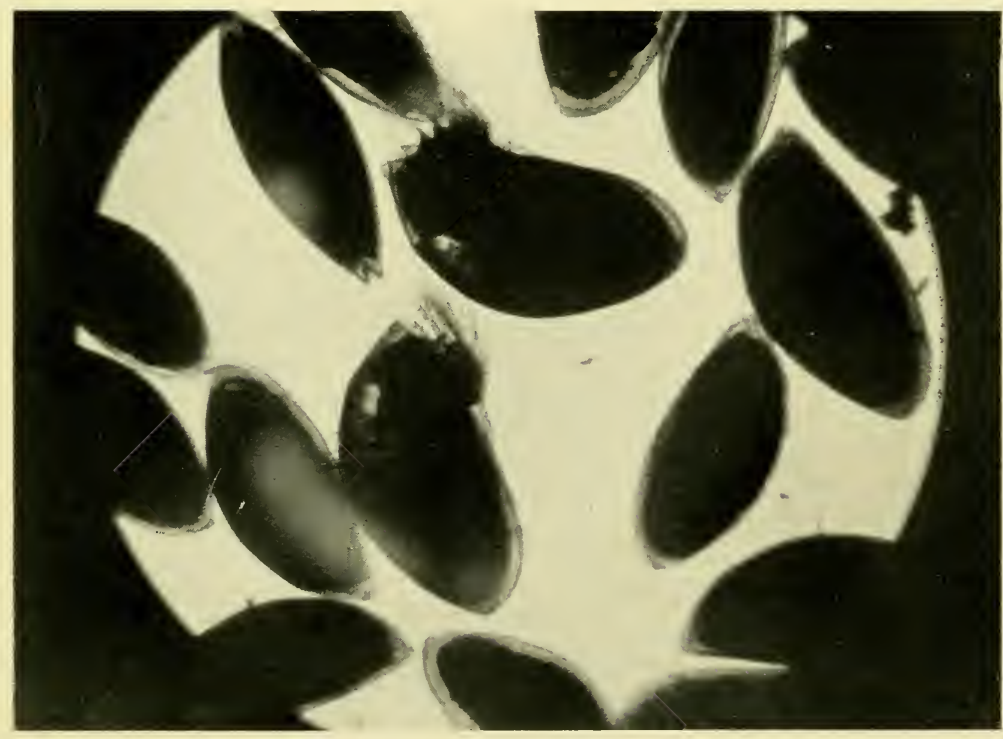

SECOND STAGE OF BARNACLE Magnified 50 diameters.

Baby barnacles are a favourite food of most young fish-especially those newly hatched, and most especially soles. 

but of these only the larval stages of the snails (gastropods) and bivalves are taken freely while floating at the surface-and chiefly by young herring and whiting.

It is impossible to read Dr. Lebour's papers without realizing their immense interest to fishermen and the bearing of her researches on the question of the 'vital statistics' of the commercial fish population. And the writer, for one, is hopeful that she will recount her experiences in non-technical language for the benefit of untrained people like himself. 1

As this is written the Marine Biological Association is seeking funds. Once let the work of Dr. Lebour and her colleagues become known, and once let the Fishing Industry realize that her discoveries tend, as they certainly do, to bring nearer the time when scientists can forecast the fishing-harvest, and men in the industry will most assuredly support the Association to the best of their ability. At present too many of them are under the impression that the Plymouth researches are intended only to be understood by men of science-and it must be confessed that the Association itself (composed as it is of some of the most self-effacing investigators in the world) has done little to dispel that misapprehension.

To the writer-perhaps wrongly-it appears to be a matter of regret that this vital inquiry into the diet of baby fishes should be confined to a station where the numbers of young commercial fishes are so restricted as they are at Plymouth. Herrings, Mackerel, Pilchard, Sprats, Gurnards, Whiting, Ling, Hake, Turbot, Brill, Plaice, Flounder, Dab, Lemon Soles, and Soles pretty well exhaust the list of Dr. Lebour's commercial species, and many of these are rare in the Plymouth youngfish nets.

One wonders whether she will ever be enabled to work at collections from waters which cradle more of the young of such fishes as are hunted by the big fleets, and more of the minute ' northern' forms which feed them. That would be one more step towards that rapprochement between Business and Science, the promotion of which is the sole object of this book.

\section{'Practical' Researches}

The writer has frequently heard fellow laymen, both in the industry and outside it, regret that naturalists were not

1 Her most important conclusions are: (a) that baby fish eat solid food while the yolk-sac is still present-e. g. herrings and brill ; $(b)$ that baby fish usually prefer a certain kind of food, and stick to it. Helpless as they appear to be, they will select the particular crustacean or molluse which their species fancies from the midst of a mass of edible plants and animals floating all round them. 
confining themselves to researches which might produce some 'practical results'. In unregenerate middle age he has, in his ignorance, given vent to such sentiments himself! But naturalists have since that time explained matters to him, and he stands here at the end of his book in a white sheet to recant his heresies, and to place the feet of his fellow-sinners on the path of orthodoxy. This particular heresy, he would plead, can carry no canonical condemnation of the delinquents. For marine science has developed many great doctors but no school of preachers to spread their doctrine. Still, the fact is obvious to any one who really thinks things out for himself that researches into the teeming life of a great hidden world like the sea-floor cannot be circumscribed by any limitations of this kind. The basic fact is that all forms of life in the sea are interdependent, and each dependent on certain chemical combinations which directly or indirectly affect them all. It is not for a layman to say whether a certain line of inquiry is or is not likely to prove 'practical'. It would be no less absurd than for a marine naturalist to offer advice on the management of a fishing-fleet. It is the duty of the naturalist to discover everything connected with the natural history of the sea.

An instance occurs to the mind. At the end of the last century Dr. Allen was engaged at Plymouth in the study of the growth and development of diatomic plants. He was actually cultivating them. He hoped to be able to make cultures of these plants which would enable him to feed young marine animals. ${ }^{1}$ It is not difficult to imagine the feelings of any owners of trawlers or drifters who might see him thus engaged. "Why can he not get on with fish and fisheries - that is what we want to know about; why plants?' Dr. Allen, if tackled on the subject, would have replied quite truly that he was experimenting with diatoms primarily because he wanted to know about them. "Could this knowledge ever really help fishermen?' He did not know. Possibly not. But he intended to know all that he could about diatoms all the same.

Then he discovered that if there was a good deal of sunshine in February and March, there would be a plentiful supply of diatoms in the sea; then that if there were plenty of diatoms in the sea in February and March there would be plenty of copepods in the sea in May. He knew that mackerel ate copepods. This problem occurred to him. Would plenty of sunshine in February mean plenty of mackerel in the following summer? In 1902, 1903, 1904, 1905, 1906, 1907, 1908, he kept two tables. One showed the numbers of hours of sunshine 1 And he has, in fact, succeeded in doing so. 


\section{PLATE X X}

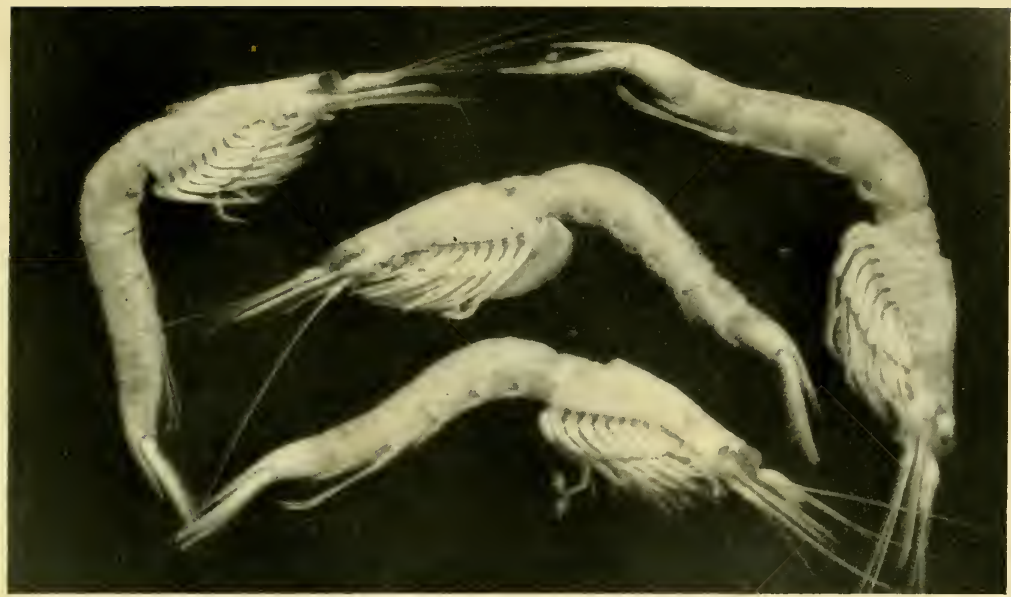

SCH I ZOPODS, or 'S PLITFOOT' SHRIMPS Eaten by young mackerel, gurnard, and turbot. Magnified 8 diameters.
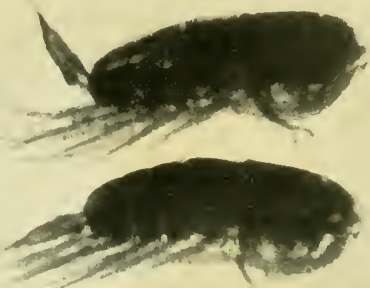

$-$
COPEPODS (CALANUS)

A favourite food of young cod, gurnard, herrings, mackerel, whiting, hake, and ling. Nagnified 8 diameters.

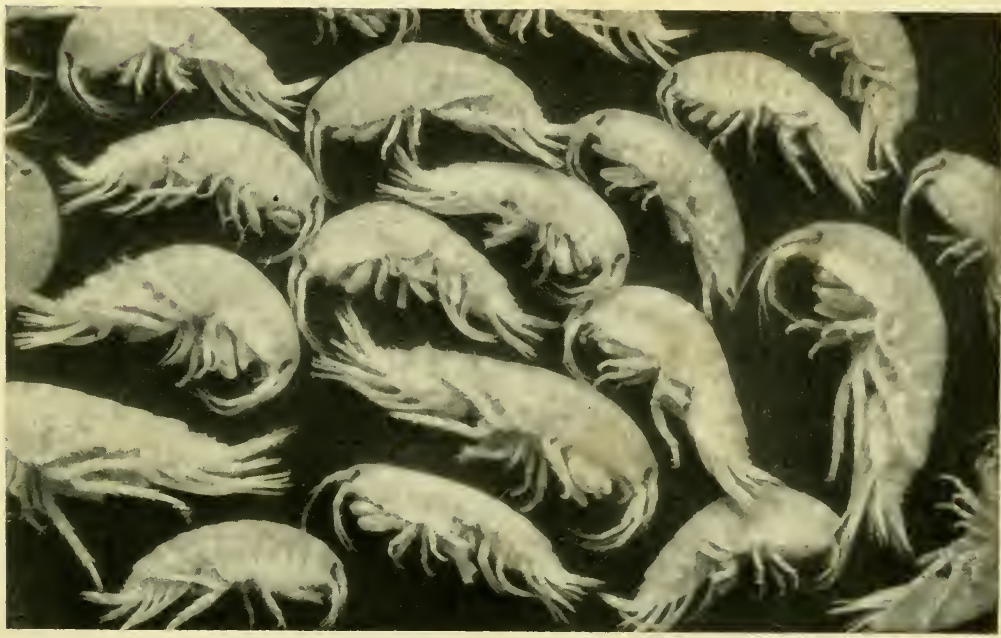

A I P H I PODS, or SA N D-H O P P E R S

Eaten by young turbot, plaice, and whiting. Magnified 5 diameters. 

in February and Narch. Another showed the number of mackerel caught by three particular steam drifters working off Cornwall in May. The average number of hours of sunshine for the seven years was $217 \cdot 5$. The average number of mackerel caught was 435,000 . In every case where the sunshine was less or more than the average, the catch of mackerel followed suit, and the curves of sunshine and the mackerel curve follow each other most faithfully. The figure is reproduced here by permission of Dr. Allen (Fig. 26).

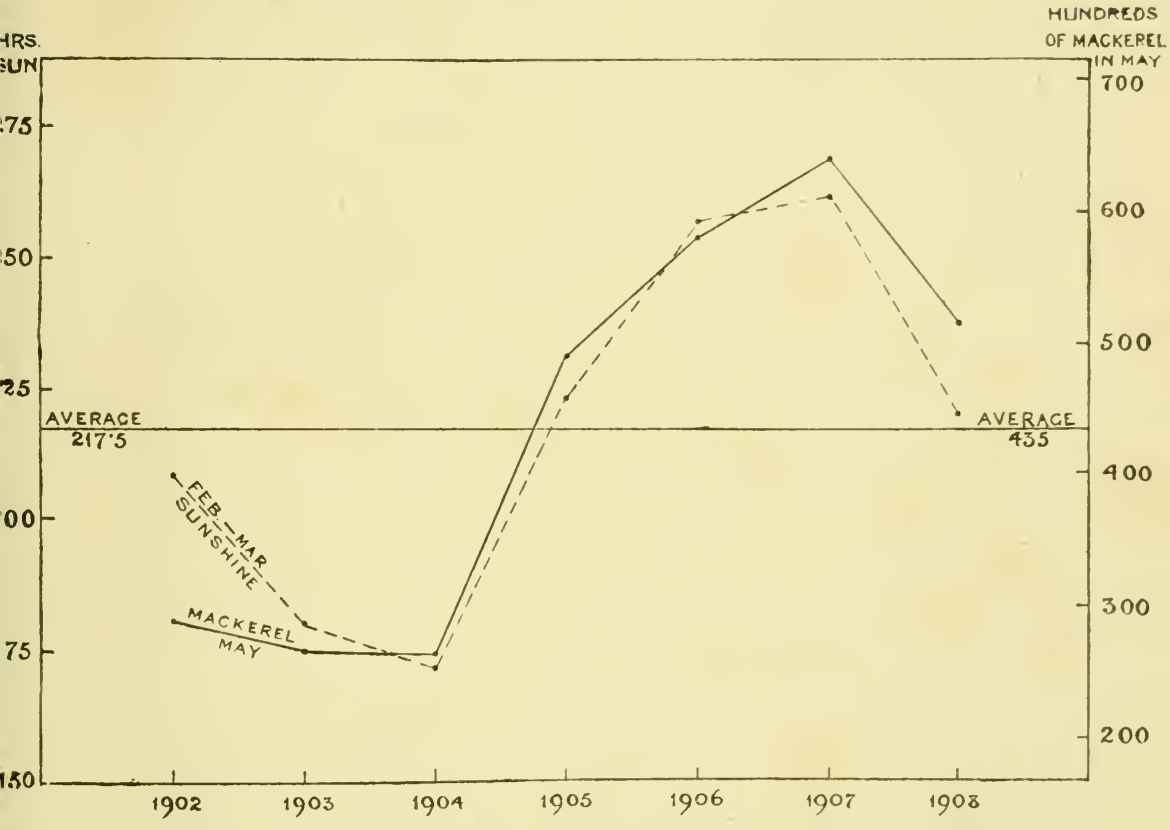

FIG. 26.-Sunshine and Mackerel. By permission of Dr. E. J. Allen.

Science would not, probably, be prepared on these data to say that the correlation between February sunshine and May mackerel was established. But it is fairly certain that no drifter owner would fail to see that the inquiry has a very direct bearing on his work. Suppose that a drifter owner had succeeded in preventing Dr. Allen from continuing his experiments with diatoms in 1898. In that case would the "practical' results have been attempted or achieved by 1908? It is unnecessary to enlarge. It may he that by 1908 every drifter owner in Yarmouth and Lowestoft was aware of what Dr. Allen 
was doing, and of the results of each experiment. The writer cannot say. If the results were not thus made known in the great drifter ports in plain and simple language, then some one blundered. 'This blunder the writer would be the last. to fasten on to any particular shoulders, since it was almost certainly due to a defective intelligence system both in the industry and in the fisheries administration. Regrets are an idle form of exercise. This book is published at the beginning of a new era in the history of the Great Fisheries, and must close on a note of hope for close and intimate collaboration between Business and science in the future. 


\section{APPENDIX I \\ 'IHE POSILION IN 1920}

Since this book went to press the Ministry of Agriculture and Fisheries and the Fishery Board for Scotland have with great courtesy placed certain figures-as yet unpublished-at the writer's disposal. The drift-net fisheries are still suffering from the loss of the Continental markets for salt herring-and so far as they are concerned the 1920 statistics reflect this fact. But the trawler and liner fleets fish to supply the home market, and in 1920 the fleets were back to full strength and over. It is interesting to compare the pre-war and post-war catches. The figures are as follows:

\section{British Landings 1}

(a) Surface Fishes (caught mainly by drifters) $1913 . \quad 1920$.

1920.

Tons. Tons. Tons. Tons.

Herring . . 588,137 389,584 Pilchard . . $1,814 \quad 3,162$

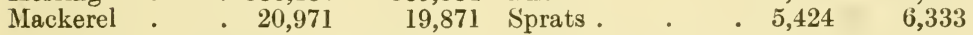

(b) 'Northern' Fishes (caught mainly by trawlers)

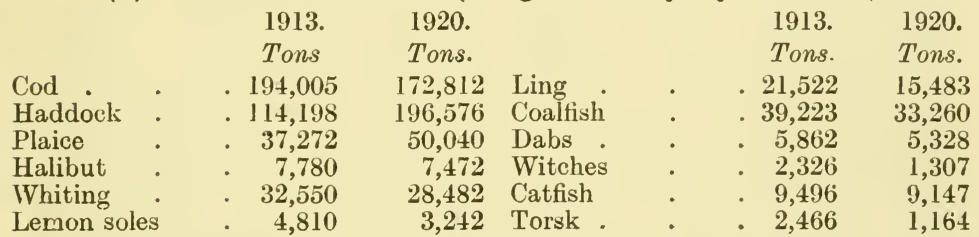

(c) 'Atlantic' Fishes (caught mainly by trawlers)

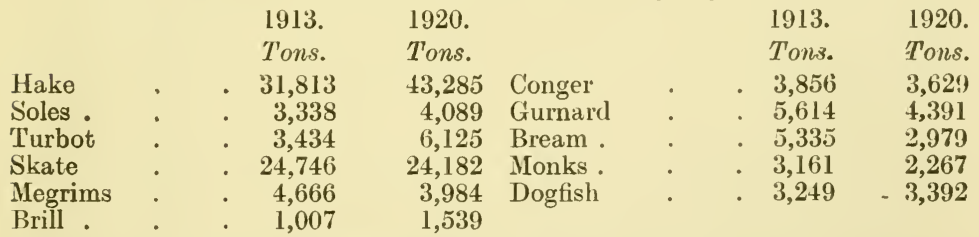

Thus the post-war landings were greater than those of 1913 in the following cases: haddock (72 per cent.) $)^{2}$; plaice (34 per cent.); hake (36 per cent.) ; soles (22 per cent.) ; turbot (78 per cent.). On the other hand, halibut diminished by 4 per cent., cod 11 per cent., whiting 12 per cent., lemon soles 32 per cent., ling 28 per cent., and so on.

But these figures do not by themselves carry us far towards

1 The Irish figures are omitted.

2 The haddock catch increased on all important grounds except Faeroe, where it fell from 7,810 tons landed by English vessels in 1913 to 2,615 tons in 1920 - a fall of 66 per cent. 
determining whether the fish population was really affected, and if so to what extent, by the fact that men were unable to devote their full energies to killing fish in the intermediate years. ${ }^{1}$

In 1913 the British steam-trawler and steam-liner fleets numbered 1,754 vessels with an average of 200 tons (gross tonnage): they landed approximately 530,000 tons of fish, or 302 tons per vessel.

In 1920 1,964 vessels, averaging 220 tons gross, landed approximately 580,000 tons or 297 tons per vessel.

The output of the deep-sea fishing ' regions' varied as follows :

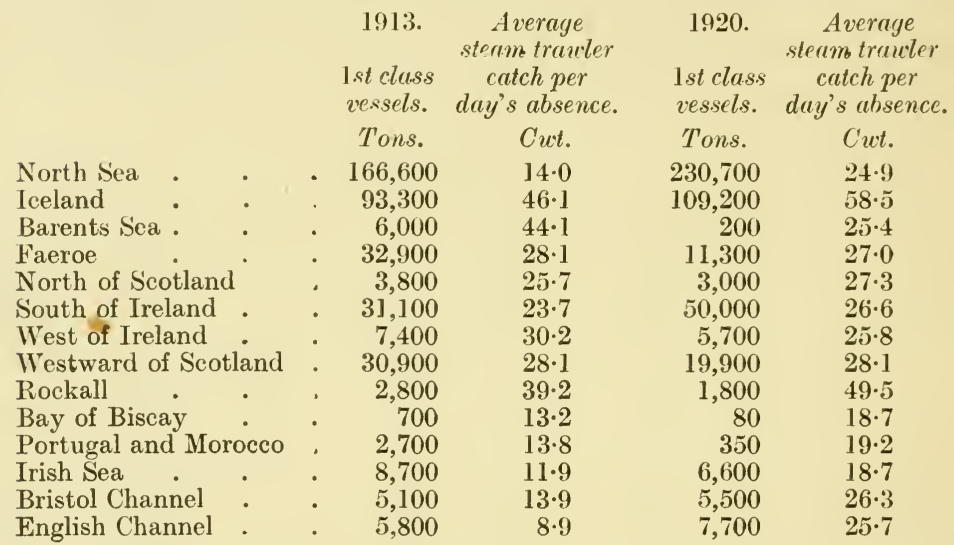

The number of fishing voyages made by steam trawlers was:

1913.

Averaging

Days

Voyages. at sea.

\begin{tabular}{|c|c|c|c|}
\hline North Sea & . & & 25,327 \\
\hline Iceland. & & & 1,722 \\
\hline Barents Sea & & & 108 \\
\hline Faeroe. & & & 1,518 \\
\hline North of Scotla & . & & 232 \\
\hline South of Irelan & & & 2,864 \\
\hline West of Ireland & & & 480 \\
\hline Westward of Sc & & & 2,234 \\
\hline Rockall & . & & 84 \\
\hline Bay of Biscay. & . & & 83 \\
\hline Portugal and M & & & 209 \\
\hline Irish S̈ea & . & & 1,951 \\
\hline Bristol Channel & • & & 787 \\
\hline English Channe & - & & 1,150 \\
\hline Total royages & . & & 38,749 \\
\hline
\end{tabular}

1920. Averaging Days

Voyages. at sea.

$\begin{array}{rr}26,726 & 6 \\ 1,727 & 21 \\ 7 & 24 \\ 402 & 17 \\ 199 & 11 \\ 3,782 & 10 \\ 399 & 11 \\ 1,250 & 11 \\ 45 & 12 \\ 7 & 12 \\ 21 & 17 \\ 742 & 8 \\ 561 & 5 \\ 574 & 4 \\ 36,442 & \end{array}$

1 For instance, the English catch of cod was heavier in 1920 than in 1913 in the North Sea (17 per cent.); Iceland (1 per cent.); South of Ireland (167 per cent.) ; and Irish Sea (44 per cent.). On most other grounds it fell off, e. g. in the Faeroes by 75 per cent, and west of Scotland 46 per cent. In fact, the cod were farther south. 
In the North Sea, therefore, the catching power employed has increased by 5 per cent., and the average eatch of the average vessel for each day spent at sea by nearly 11 per cent. ; to the southward of Ireland the catching power has increased 32 per cent. and the average catch by 2.9 per cent. The number of Iceland voyages has not changed materially, but the average catch has increased about 12 per cent. In the English Channel the creation of a brand-new first-class steam-trawler industry brings this area for the first time into the list of the Great Fisheries.

The number of royages made by English vessels to every other ground has diminished, viz. in the Barents Sea by 98 per cent., Faeroe 73 per cent., North of Scotland 16 per cent., West of Ireland 17 per cent., Westward of Scotland 44 per cent., Rockall 46 per cent., Bay of Biscay 91 per cent., Portugal and Morocco 89 per cent., Bristol Channel 28 per cent.

The fluctuations in the average daily catch per vessel since 1906 have been as follows :

1906. 1907. 1908. 1909. 1910. 1911. 1912. 1913. 1920.

\begin{tabular}{|c|c|c|c|c|c|c|c|c|}
\hline North Sea & . $17 \cdot 6$ & $17 \cdot 0$ & $16 \cdot \tilde{5}$ & $16 \cdot 9$ & $16 \cdot 2$ & $16 \cdot 2$ & $15 \cdot 7$ & $14 \cdot 0$ \\
\hline Iceland & $44 \cdot 2$ & $44 \cdot 1$ & $47 \cdot 9$ & $43 \cdot 6$ & $44 \cdot 3$ & $48 \cdot 0$ & $46 \cdot 0$ & $46 \cdot 1$ \\
\hline Barents Sea & $40 \cdot 1$ & $43 \cdot 1$ & $47 \cdot 4$ & $59 \cdot 8$ & $60 \cdot 0$ & $49 \cdot 2$ & $38 \cdot 1$ & $44 \cdot 1$ \\
\hline Faeroe & $31 \cdot 1$ & $34 \cdot 3$ & $28 \cdot 0$ & 34.9 & $30 \cdot 2$ & $31 \cdot 4$ & $31 \cdot 6$ & $28 \cdot 1$ \\
\hline North of Scotland & $25 \cdot 0$ & $37 \cdot 9$ & $33 \cdot 3$ & $26 \cdot 5$ & $24 \cdot 7$ & $24 \cdot 2$ & $23 \cdot 7$ & $25 \cdot 7$ \\
\hline South of Ireland & - $26 \cdot 9$ & $26 \cdot 9$ & $24 \cdot 7$ & $25 \cdot 8$ & $24 \cdot 2$ & $25 \cdot 8$ & 28.9 & $23 \cdot 7$ \\
\hline West of Ireland & . $21 \cdot 4$ & $25 \cdot 4$ & $23 \cdot 7$ & $25 \cdot 8$ & $27 \cdot 2$ & $30 \cdot 6$ & $31 \cdot 8$ & $30 \cdot 2$ \\
\hline West of Scotland & $21 \cdot 1$ & $22 \cdot 6$ & $23 \cdot 3$ & $23 \cdot 8$ & $26 \cdot 2$ & $2 \varepsilon$ & 7 & $28 \cdot 1$ \\
\hline Rockall & $38 \cdot 9$ & $41 \cdot 1$ & $33 \cdot 3$ & $39 \cdot 5$ & $14 \cdot 7$ & $29 \cdot 2$ & $41 \cdot 9$ & $39 \cdot 2$ \\
\hline Bay of Biscay & $15 \cdot 9$ & $19 \cdot 4$ & $18 \cdot 6$ & $17 \cdot 2$ & $20 \cdot 1$ & $19 \cdot 3$ & $16 \cdot 3$ & $13 \cdot 2$ \\
\hline al and Morocco & $6 \cdot 5$ & $4 \cdot \tilde{5}$ & 9 & $8 \cdot \tilde{5}$ & $12 \cdot 1$ & 11 & 5 & $13 \cdot 8$ \\
\hline Irish Sea & . $15 \cdot 6$ & $15 \cdot 3$ & $15 \cdot 5$ & $14 \cdot 3$ & $12 \cdot 2$ & & $14 \cdot 0$ & $1 \cdot 9$ \\
\hline Bristol Channel . & $13 \cdot 1$ & $16 \cdot 7$ & $13 \cdot 8$ & $14 \cdot 9$ & $17 \cdot 0$ & $17 \cdot 7$ & $15 \cdot 6$ & $13 \cdot 9$ \\
\hline English Channel & $11 \cdot 3$ & $10 \cdot 5$ & $16 \cdot 3$ & $13 \cdot 6$ & $12 \cdot 4$ & $12 \cdot 4$ & $13 \cdot 8$ & $8 \cdot 9$ \\
\hline
\end{tabular}

Had the writer been asked to make a forecast of the last column of this table in 1918 he would not have hesitated. 'Two years ago he believed that the population of the sea varied more or less in inverse ratio to the number of fish killed by fishermen, and that nature, left to herself, would add an approximately even accretion to the fish population every year. During the war fishermen were not able to kill many fish. It followed that a very large stock must have accumulated in the sea during the War. It was apparently safe to anticipate that the 1920 catch would be about double the pre-war maximum. The fish had been practically unmolested on the spawning grounds in 1915, 1916, 1917, and 1918 : the fleets would still be below strength in 1919 which would give the fish comparative 
peace for another year. Leaders in the industry thought that as soon as the trawling fleet got back to full strength the annual catch of English trawl fish would be not less than $1,250,000$ tons, and that it would probably be nearer $2,000,000$ tons. These calculations were based on the assumption that 1,200 English trawlers would be landing an average of about 19 tons a week each. As a matter of fact 1,541 English trawlers in 1920 landed 434,000 tons - an average per ship of less than 6 tons a week! The industry has been keenly aware that it misjudged the situation in 1918. It is fairly evident that if intense fishing were the main factor in diminishing the fish population as a whole, and if an approximately even proportion of infant fish survived their birth every year, the 1920 catch would have been within a few thousand tons of the forecast instead of 800,000 tons below it. The task before naturalistsmany (if not most) of whom shared the optimism of fish catchers in 1918-is to explain in intelligible terms the variations in the strength of each tribe of fish on each of the great fishing grounds, and to determine how far these variations are due to restrictions on fishing and how far to forces outside human control.

The position can be summarized as follows:

the steam fishing fleet has increased by about 11 per cent.; the catch has increased by about 9 per cent. ;

the value of the catch has increased by about 99 per cent. ; the landings per vessel have decreased by about 2.6 per cent. ; the gross earnings per vessel have increased by about 74 per cent. ; the cost of catching fish has increased (at least) by 150 per cent.

So all is not well with the Great Fisheries in 1921. It is the task of Science and Industry to diagnose the disease, examining each symptom in close collaboration, and to find remedies. A fishing royage has always been, and will probably always be, an adventure in which the risk of failure is great, for the seas which cover the fishing grounds are vast (though not ' trackless ') areas -in which it is always easy to miss the prey. Obviously every addition to our knowledge of the laws which govern the wanderings of fish over and between the grounds diminishes pro tanto the danger of a 'bad voyage'. 'The writer for the last six months has listened to men of business expounding the doctrine that British fisheries can at this juncture be saved only by diminishing the cost of production. He believes, with many of them, that branches of science other than biology will be called upon to find, amongst other things, more efficient marine engines and nets, and some preservative less costly than ice. But, when all is said and done, no operation is more 
hopelessly wasteful than towing a trawl over grounds which do not hold tish, and thousands of pounds are expended every year in steaming to distant grounds before ever a trawl is shot. We thus arrive at a direct connexion between the marine naturalist and the problem of 'cost of production'. One of his tasks is to say where and when particular kinds of fish are likely to be plentiful, and to save industry the expense of fruitless searches. Naturalists have advanced, as we have seen, some way towards, but are still very far from having attained, a degree of knowledge which would enable them to perform this function.

'They must now ' carry on' with their search for the causes of the fluctuations in the catches of various species, remembering of course that a diminished eatch does not by itself necessarily denote a diminution of the stock in a particular area of the sea bottom. It may always be due to the fact that fewer vessels have searched the area, that they were less competently handled, or that they were not carrying good weather-or good luck.

Much progress, no doubt, can be made by studying ashore the scales and otoliths and measurements of samples landed from commercial vessels. But fishery problems cannot be solved fully until our naturalists are adequately equipped with ships for the exploration of the sea bed. How far other nations will be able in the next few years to solve our British problems for us remains to be seen. Our statesmen have quite definitely refused the minimum equipment which would enable us to solve some of the most important of them for ourselves. No blame attaches to the politicians. They are, after all, laymen, and little attempt has hitherto been made by the initiated to share with laymen a proper appreciation of Oeean Research.

\section{APPENDIX II}

\section{FLUCIUATIONS IN THE LANDINGS AT ENGLISH PORTS, 1906-20}

In the following tables fishes have been classified, as Hjort classifies them: (a) according as they are derived chiefly from northern waters or from the Atlantic (see chap. xxxii): (b) according as they occur in shallower or deeper waters; with the following results : 
T'ABLe I

Bathymetric Classification of Fishes

\section{(a) Northern Species}

Percentage in Percentage in Percentage in Shallow Water, Medium Water, Deep Water,

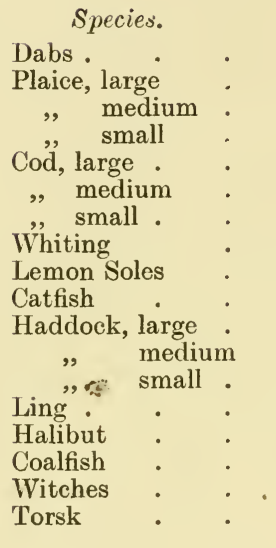
0-20 fathoms. 20-55 fathom.s. over 55 fathom.s.

\section{(b) Atlantic Species}

Percentage in Percentage in Percentage in Species.

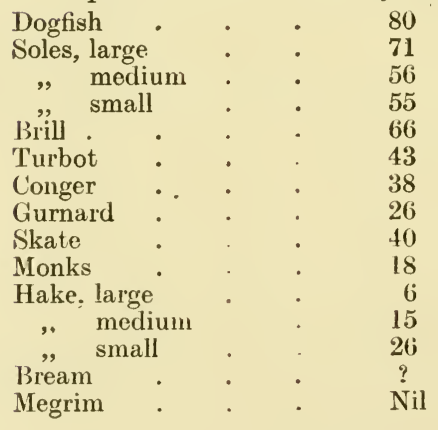
Shallow Water, Medium Water, Deep Water, 0-20 fathombs. 20-55 fathoms, over 55 fathomb.

$\begin{array}{cc}20 & \text { Nil } \\ 29 & \text { Nil } \\ 44 & \text { Nil } \\ 45 & \text { Nil } \\ 34 & \text { Nil } \\ 56 & 1 \\ 60 & 2 \\ 60 & 14 \\ 51 & 9 \\ 64 & 18 \\ 24 & 70 \\ 36 & 49 \\ 39 & 35 \\ ? & ? \\ 12 & 88\end{array}$

The total landings of each species in English ports for the years1906-13 inclusive, and for 1920 are given below in Table II : 
LANDINGS AT ENGLISH PORTS, $1906-20$ 20\%

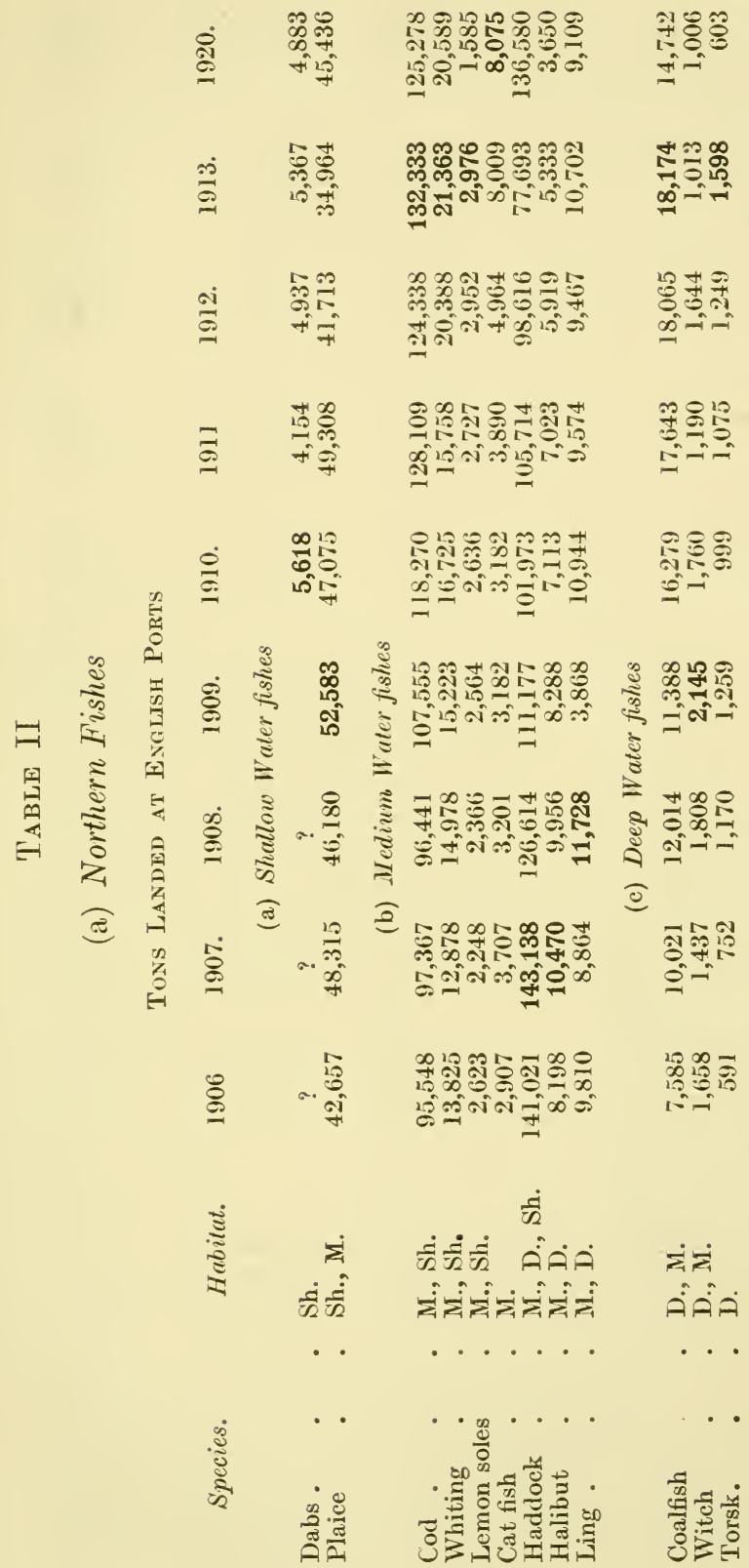


206 LANDINGS AT ENGLISH PORTS, $1906-20$

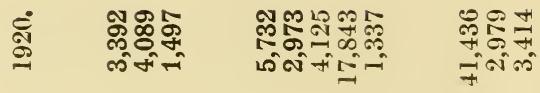

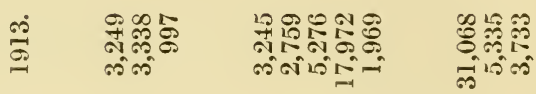

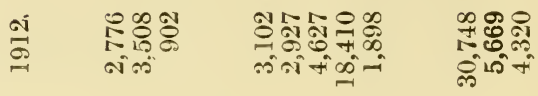

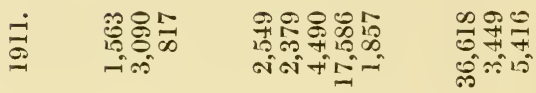

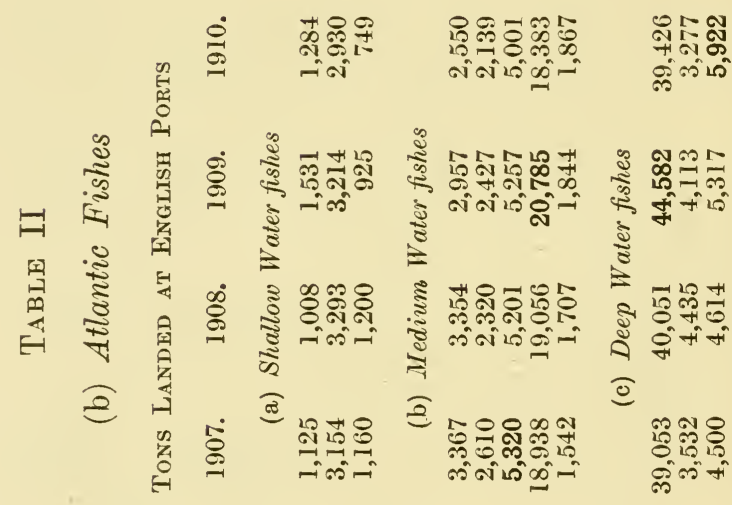

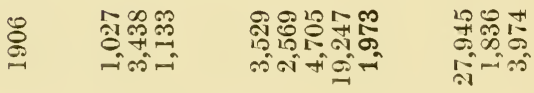

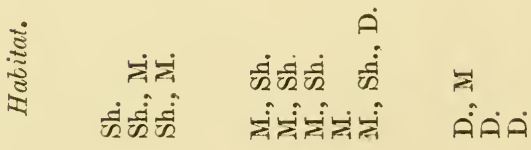

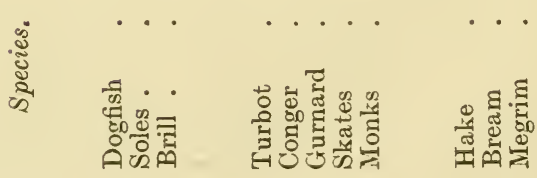


The warning must be repeated that the figures of the inclusive catches from all grounds are by themselves unsafe guides for the student of the rital statistics of the fish population. He must study the fluctuations on each of the grounds separately, and check the gross landings from the tables which indicate the yield per vessel per day's absence from port. Not infrequently he will find that the variations in the weight of fish landert may fairly be ascribed to the growth or diminution in the number of vessels which visitert the grounds in a particular year. The writer has reduced the tables for individual fishing grounds, and the comparative statements of daily catch per vessel of the staple species, to graphs. They give no convincing indication that restrictions on fishing during the war have resulted in any great accumulation of fish in the north-eastern Atlantic, and it seems highly probable that the annual fluctuations in the exploitable stock are due, primarily at any rate, to causes altogether outside the control of man. But the examination of post-war conditions is outside the scope of this work, and this appendix is added only to show the lines along which the explorers of the sea bottom are likely to work in the immediate future.

\section{APPENDIX III}

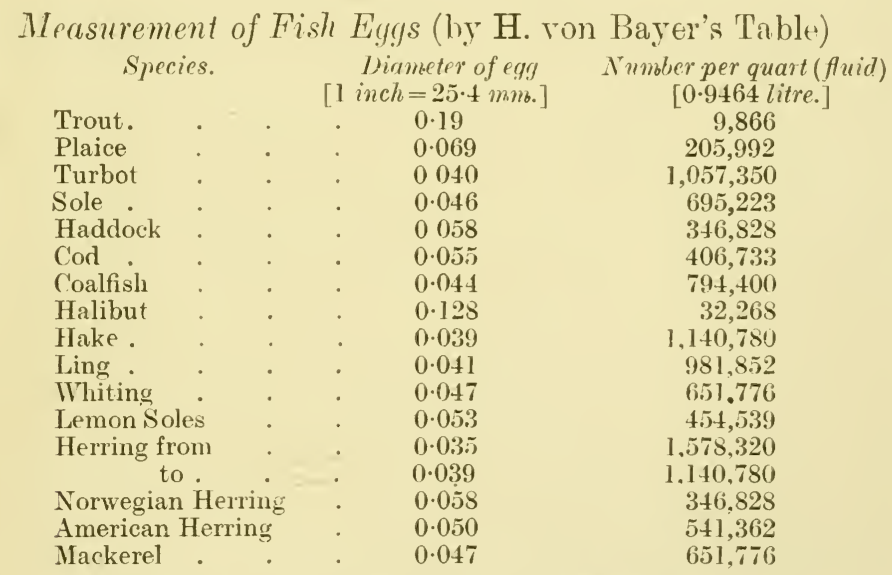

Solids increase as the third pouer of their diameters.

Example: d $=0.127^{\prime \prime}$ diameter of white fish egg (determined).

$\mathrm{n}=33,036$ number of white fish eggs per quart (actually counted).

$d_{1}=0 \cdot 1406^{\prime \prime}$ diameter of shad egg (determined).

$\mathrm{n}_{1}=$ number of shad eggs per quart (sought).

$$
\begin{gathered}
\mathrm{d}^{3}: \mathrm{d}_{1}{ }^{3}=\mathrm{n}_{1}: \mathrm{n} \therefore \mathrm{n}_{1}=\frac{\mathrm{d}^{3} \mathrm{n}}{\mathrm{d}_{1}{ }^{3}} \text { or } 0 \cdot 127^{3}: 0 \cdot 1406^{3}=\mathrm{n}_{1}: 33,036 \\
\mathrm{n}_{1}=\frac{0 \cdot 127^{3} \times 33,036}{0 \cdot 1406^{3}}=24,345 \text { (answer) }
\end{gathered}
$$




\section{BIBLIOGRAPHY}

\section{MISCELLANEOUS}

1921 Petersen, C. T. J. On the Stock of Plaice, \&c. (Rep. Dan. Biol. Station, Copenhagen, No. xxvii).

1921 McIrtosh, W. C. The Resources of the Sea, 2nd edition (Cambridge)

1920 CLARK, R. S. Young Stages of Teleosteans (Journ. M.B.A., July).

1920 Storrow, B., and Cowan, D. Herrivg Investigations (Rep. Dove Mar. Lab., N.S., ix).

1920 Lebour, M. V. Food of Young Fishes (Journ. M.B.A., July).

1920 Orton, J. H. Sea Temperature and Breeding in Marine Animals (Journ. M.B.A., July).

1920 Le Danois, E. The Hake (Off. Sci. des Pêches Marit., Paris).

1920 Jenkins, J. T. The Sea Fisheries (Constable).

1919 Jollansen, A. C. Investigation as to the effect of the restriction on fishing during the war (Medd. fra Komm. Ser. Fiskeri, Bd. v, 1919).

1919 Storrow, B., and Cowan, D. Herring Irvestigations on Northumberland Coast. (Rep. Dove Marine Lab., Cullercoats, N.S., viii).

1919 Lebour, M. V. The Food of Post-larval Fish, No. 2 (Journ. M.B.A., vol. xii, No. 1).

1918 Peterses, C. G. J. The Seabottom and its production of Fish Food (Rep. Dan. Biol. Station, Copenhagen, xxv).

1918 Green, N. Fisheries of the North Sea (Methuen).

1918 Samuel, A. M. The Herring (Murray).

1917 Allen, E. J. Post-larval Teleosteans (Journ. M.B.A., vol. xi, No. 2).

1916 Hefford, A. E. Sexual Differentiation of P'LAICE (Bd. of Agr. and Fish.).

1916 Storrow. Herrixg Investigations (Rep. Dove Mar. Lab., N.S., v).

1916 Storrow. Notes on the Age and Growth of Fish (Rep. Dove Mar. Lab., N.S., v).

1915 Gardiner, J. S. Geography of British Fishes (Geogr. Journ., June).

1915 Gardiner, J. S. Submarine Slopes (Geogr. Journ., March).

1915 Wollaston, H. J. B. Spawning Grounds of the Plaice (Bd. of Agr. and Fish.). Fish. Investns., Ser. II, vol. ii, No. 4.

1915 Todd, R. A. Food of the Plarce (Bd. of Agr. and Fish.). Fish Investns., Ser. II, vol. ii, No. 3.

1915 Wallace, W. Age, Growth, and Sexual Maturity of the Plaice (Bd. of Agr. and Fish.) Fish. Investns., Ser. II, vol. ii, No. 2.

1915 Masterman, A. T. Plaice Fisheries of the North Sea ( $B d$. of Agr. and Fish.). Fish. Investns., Ser. II, vol. ii, No. 1.

1914 Russell, E. S. Market Measurements in relation to English Haddock Fishery (Bd. of Agr. and Fish.). Fish. Investns., Ser. II, vol. i, pt. I.

1914 Chark, R. S. General Report on the Larval and Post-larval Teleosteans (Journ. M.B.A., vol. x, No. 2).

1914 Menk, A., and Storrow, B. Herring Races-Preliminary Work (Rep. Dove Mar. Lab., N.S., iii).

1914 Nilsson, O. A Contribution to the Biology of the Mackerei (Pub. de Circ., No. 69, p. 47, Copenhagen).

1912 MurraY, J., and HJort, J. The Depths of the ()cean (Maemillan).

1912 Fowler, G. H. The Science of the Sea (Murray).

1912 Hérubel. Sea Fisheries, their Treasures and Toilers (I'nwin).

1911 Mrnchis, C. O. Sea Fishing (Black).

1911 Fulton, T. W. The Sovereignty of the Sea (Blackwood). 
1909 Patterson, A. H. Man and Nature in Tidal Waters (Methuen).

1909 Gruvel. Les Pêcheries de la côte occidentale d'Afrique, 1906 (Combt. rendus Congrès Pêches Marit. Sables d'Ologne).

1909 Petersen, C. G. J. Larval and Post-larval stages of some Pleuro. NECTIDAE (Medd. Koinm. Havund. Fisk. Bind 3).

1908 Committee on Fishery Investigations Evidence (Cd. 4304, price 4s. 6d.).

1908 Jofristone, J. Conditions of Life in the Sea (Cambridge).

1907 HJoRT, J. Some Results of the International Ocean Researches (Scottish Oceanographical Laborutory, 21 Rutland Street, Edinburgh).

1907 Schmidt, Jos. Post-larval stages of the Livas (Medd. Komm. Havund. Fisk. Bind ii. 7).

1907-11 KRÜMMEL, O. Handbuch der Oceanographie.

1907 Anthony, R. La Piscifacture du Turbot (Compt. rendus Congrès Pêche Marit., Bordcaux).

1907 Schmid, Jos. Post-larval development of some North Atlantic Gadoids (Medd. Komm. Hav. Fisk, Bind ii. 8).

1907 ScotT, A. Notes on the Food of Young Fishes (Lanc. and Western Sea Fish Laby. Rept.).

1907 Schmidt, Jos. Post-larval development of the Hake (Medd. Komm. Havund. Fisk. Bind ii. 7).

1906 Holt, E. W. L., and Byrne, W. Fishes of the Irish Atlantic Slope. Ann. Rept. Fish. Ireland.

1906 KyLE, H. M. Statistics of the Sea Fisheries in the countries of North Europe; Bull. Stat. Inter. Fishy. Investns.

1906 Nathansohn, A. L'influence de la circulation verticale des eaux sur la production du Plankton Marin. (Bull. Mus. Océanog., Monaco, 62).

1906 Cligny, A. Transplantation des poissons marins. (Bull. Soc. Aqui. et Pêches).

1905 Fabre-Domergue ét Biétrix. Le Développement de la Sole ( $a b$. Zool. Marit., Concarneau).

1905 Johnstone, J. British Fisheries (Williams \& Norgate).

1905 CunvinghaM, J. T. Zones of Growth in the Skeletal structures of Gadidae and Pleuronectidae (Ann. Rep. F.B.S.).

1904-6 Stuart Thomson, J. The Periodic Growth of Scales in Gadidae as an Index of Age (Journ. M.B.A., N.S., iii).

1905 Holt, E. W. L., and Byrne, L. W. The British and Irish Species of Solea (Ann. Rep. Fish. Ireland, 1902-3, Part 2, App. V, 1905).

1904 Petersex, C. G. J. Larval and Post-larval stages of the Losg Rough Daв, \&c. (Hedd. Komm. Havund. Fisk. Bind 1).

1904 Afralo, F. G. The Sea-Fishing Industry of England and Vales (Stamford).

1904 Wrilliamson, H. C. Post-larval and early young stages of the W'TTCH (Ann. Rep. F.B.S.).

1903 Johnstone, J. Identification of Fish Eggs (Lanc. Sea Fish. Laby. Rept.).

1902-3 Garstang, W. Experiments in the Transplantation of Small Plaice (Int. Fish. Invest. M.B.A., Rep. J).

1902-3 Wallace, W. Preliminary lnvestigations on the Age and Growthrate of PLAICE.

1900 Fultox, W. The Currents of the North Sea (Ann. Rep. F.B.S.; also in 1897 ).

1900-3 Cleve, P. T. Geographical Distribution of Atlantic CopePoda and their Physical Condition (Ofvers. $K$. vet Akadem., Stockholm, lviii).

1900 Garstang, W. The Impoverishment of the Sea (Journ. M.B.A., N.S., vi).

1900 Garstaxg, W. Preliminary Experiments on the Hatching of Sea Fish Larvae (Journ. M.B.A., N.S., vi).

1899 Malard, A. E. Sur le Développement et la Pisciculture du Turbot (Comptes rendus de l'Académie des Sciences, Paris).

1899 Garstang, IV. Experiments on Sea Fish Culture (Rep. Br. Assoc.).

1898 MURra广, SiR J. On the Annual Range of Temperature in the Surface Waters of the Ocean (Geo. Journ., Vol. xii, pp. 128-30). 
1898 Garstang, W. Recherches sur l'histoire naturelle du Maquereau (Congrès pêche marit., Dieppe).

1897-9 Allex, E. J. The Present State of Knowledge with regard to the Habits and Migrations of the Mackerel (Journ. M.B.A., N.S., v).

1897-9 Garstaxe, IV. Report on the Surface Drift of the English Channel and neighbouring Seas (Journ. II.B.A., N.S., v).

1897-9 Garstang, W. Variations, Races, and Migrations of Macherel (Journ. M.B.A., N.S., v).

1897 Brice, J. J. Manual of Fish Culture (United States Burcau of Fisheries).

1897 MoIntosh, W. C., and Mastermas, A. T. 'The Life-Histories of British Marine Fishes (Cambridge).

1896 Cunningham, J. T. Natural History of the Marketable Marine Fishes of the British Islands (Macmillan).

1895 Garstang, W. Faunistie Notes at Plymouth 1893-4 (Journ. I.B.A., vol. iii, N.S., 1893-5).

1894 Gourret, P. Les Pêcheries et les Poissons de la Méditerranće (Pro. vence), Paris.

1893-5 Grenfell, W. T. A Voyage to the Newfoundland Fishery Banks (Journ. M.B.A., N.S., iii).

1893-5 HoLt, E. W. L. The Ieeland Trawl Fishery (Journ. IJ.B.A., N.S., iii).

1893-5 Holt, E. W. I. Notes on Pleuronectes mierocephalus (LEMoN Sole) (Journ. M.B.A., N.S., iii).

1893 Holt, E. W. L. Eggs and Larval and Post-larval stages of Teleosteans (Sci. Trans. Royal Dublin Soc., vol. v, Series 2).

1891-2 Holt, E. W. L. The Turbot (Journ. M.B.A., N.S., ii).

1891-2 Holt, E. W. L. The Halibet (Journ. M.B.A., N.S., ii).

1891 Cunnixgham, J. T. The Rate of Growth of some Sea Hishes (Journ. I.B.A., vol. ii, 1891-2).

1891 Prince, E. E. Derelopment of the Angler Fish (Monk) (Ann.Rep.F.B.S.).

I890 Micintosh, W. E., and Prince, E. Life-Histories of Teleostean Food and other Fishes (Trans. Roy. Soc. Edinburgh, xxxv, p. 3, No. 19).

1890 Cunningham, S. J. The Common Sole, Mar. Biol. Assoc.

1885 Bertram, J. G. The Harvest of the Sea (Gardner).

1884 Gordon, W. J. Our Country's Fishes (Handbook) (Simpkin, Marshall, Hamilton, Kent \& Co.).

1884 Vaildant, A. Comptes rendus des voyages du Travailleur et du Talisman.

1861 Mitchell, J. M. The Herring (Edinburgh).

\section{SOME PUBLICATIONS OF THE INTERNATIONAL COUNCIL}

\section{(1) Publications de Circonstance}

No. 3. The Literature of the Ten Principal Food Fishes of the North Sea.

No. 8. On the Spawning of the CoD in Autumn in the North Sea. 'T. Weny'ss Fulton.

No. 22. Notes Biologiques sur les Copepodes de la Mer Norvegienue. 1. Damas.

\section{(2) Appendices to General Reports 1902-t}

Ippendix G. Short Review of the Results of the International Investigations J. Hjort and C. G. J. Petersen.

(3) Reports of Commillee A

No. 1. Statistical Research into the Biology of the Hadvock and Cov in the North Sea. By Helland-Hansen.

No. 2. On the Statistics of the Aberdeen Trawl-fishery, 1901-6, with special reference to the COD and HADDOCK. D'A. W. 'Thompson.

No. 3. Contribution à la Biologie des Gadides. D. Damas.

No. 4. The Distribution of the Pelagic liry and the Spawning liegions of the Gavoros in the North Atlantie from Iceland to Spain. Johs. Schmiclt. 
No. 7. On the Con marking Experiments in the North Sea, 1904-7. J. O. Borley.

These Reports are published as vol. $\mathrm{x}$ of the Rapports et Procès-Verbaux of the council.

(4) Independent Reports

\section{England}

Experiment on the Transplantation of Small Plaice. W. Garstang.

The Age and Growth Rate of PlaICE in the Southern North Sea. IT. Wallace.

The Food of Fishes. R. A. Todd. 1903-5 (two reports).

These are contained in vol. i, North Ser Fish. Invest. Com. (Southern area), 1903 [Cd. 2670].

\section{Scotland}

The Temperature and Salinity of the Surface Waters of the North Sea, 1903. A. J. Robertson. First Rept. North Sea Fish. Invest. C'om. (Northern area) 1905 [Cd. 2612].

\section{Denmberk}

Larval and Post-larval stages of Long Rough Dab and Pleuronectes. C. G. J. Petersen, 1904. I, 1.

Distribution of Young PlaICE in Danish Waters. A. C. Johansen, 1908. III, 4.

Pelagic Larval Halibut. Johs. Schmidt, 1904. I, 3.

Pelagic Post-larval stages of the Atlantic species of GaDus I. Johs. Schmidt, 1905. I, 4.

Pelagic Post-larval stages of the Atlantic species of GADus II. Johs. Schmidt, 1906. II, 2 .

Larval and Post-larval stages of the Tonsk. Johs. Schmidt, 1905. I, 8.

Larval and Post-larval stages of Pleuronectidae. C. G. J. Petersen, 1906. II, 1.

Marking Experiments on PlaICe and CoD in Icelandic Waters. Johs. Schmidt, 1907. II, 6 .

Post-larval Development of the HAKE. Johs. Schmidt, 1907. II, 7.

Plankton Investigations in the Waters round Iceland, 1903. Ove Paulsen, 1904. I p., 1 .

Studies in the Biology of CaLanus finmarchicus round Iceland. Ove Paulsen, 1906. I p., 6

The Danish papers referred to above appear in the Heddelelser fra Kombission for Havundersogelser. The series quoted is 'Fiskeri' except those marked ' $\mathrm{p}$ ', where the series is 'Plankton'.

\section{Sweden}

On the Influence of Ice Melting on Oceanic Circulation. O. Petterson, 1903.

On the Influence of Ice Melting on Oceanic Circulation. A. Sandström, 1903.

In Svenska Hydrografisk Biol Kommissionens Skrifter, II, Goteburg, 1905.

\section{Norway}

The Scales of the Herrixg as a Means of Determining Age, Growth, and Migration. Knut Dahl, 1907. Rept. Norwegian Fishery and Marine Iıvestigutions, vol. ii, Nó. 6.

\section{PUBLICATIONS OF MINISTRY OF AGRICULTURE}

\section{North Sea Fisheries Investigation Combittee}

(a) Northern Area Fishery Board for Scotland. 5 volumes Hydrography. Plankton. Statistical and Various, 1905-13.

(b) Southern Area M.B.A. 4 volumes, 1908-11. Various and PlaICE Marking Transplantation, \&c.

(c) Report on Plaice Fisheries of the North Sea. 4 volumes, 1908-11.

2. Statistical 'Tables relating to the Catch of PlaICE, Haddock, CoD, and HAKE, 1906-10. Published in 1912 (!). 



\section{T N D E X}

Abbs, Rev. Cooper, 77.

Aberdeen, 32, 53, 70, 77 .

hake, 109.

herrings, 152.

Abyssal fishes (Macruridae), 112.

Age of fish, 21, 22, \&c. See Scalereading.

cannot be inferred from size, 149 , $173,175$.

Agriculture, Irish Department, 7.

Agriculture and Fisheries, Ministry of, $7,51,61,62,63,64,111,113$, 198, \&c.

Alcyonium (false coral), 124 .

Allen, E. J., 7, 181, 184, 196, 197, \&c. correlation of sunshine and mackerel, 196, 197.

hopes to direct fishermen to profitable grounds, 158.

Amphipods(sandhoppers), 15, 1+1, 142

Andersson, K. A., 178.

Anstruther, 152, 153.

Anthony, R., 67-70, 96, 126.

'Areas' in North Sea, 41, 51, 52, 53, $73,82,89,135,139,143,144$.

Atkinson, G. T., 47, 48, 56, 182.

'Atlantic' fishes and animals, 20, 186-9, 191, 199, 203, 204, 206.

Baby fish :

feed before yolk-sac is absorbed, $36,68,69,74,146,160,182,195$.

food of, $15,25,95,96,160,192,193$, $194,195,195 \mathrm{n}$.

cod, 96 .

haddock, 83.

hake, 125 .

herring, 160.

lemon sole, 146 .

ling, 136.

mackerel, 182.

plaice, 36 .

soles, 73,74 .

turbot, 69 .

whiting, 140, 141, 142 .

select their favourite food while

Ballantrae, 152. apparently helpless, $195 n$.

Banff, 152, 153 .

Barra, 152.

Barrett, F., 24, 28.
Barmacles, 15, 25, 74, 160, 194.

Barnes, E. IV., 69.

von Bayer, H., 89, 207.

Bertram, J. G., Harvest of the Sea, 32 , 77.

Berwick, 152, 153.

Bettess, R., 119, 121, 122.

Bibliography, 208-10.

'Bickerdyke ', 132.

Biétrix, M., 66, 67, 74 .

Bloomfield, J., 28, 56, 158.

Blue Ling (Holva byrkelange), 135, 137.

Blyth, 76, 88 .

Boeck, Dr.

on effect of temperature (1862), 159.

work on herring eggs (1860), 157.

Boothbay, U.S.A., hatchery at, 79.

Borley, J. O., 48, 59.

Boston, $32,65,77,88$.

Bowman, A., 113, 115, 119.

Brander, A. J., 8.

Brander, E. W. H., 176.

Bream, 14, 118, 199, 206.

Brixham, 71.

Brill, 14, 36, 195 n., 199, 206.

British food fishes, comparative value (1913), 14

Broch, H., on herring scales, 164 .

Buckland, F., 159.

Bund, J. Willis, 185.

Burgoyne, C. A. W., 8.

'Business' and 'Science', should interchange ideas, $13,15,16,19$, $22,24,25,27,28,29,30,45,50$, $61,70,83,96,97,107,124,126$, $127,142,149,160,177,185,192$, 195, 197, 201, 202, 203. See also Popular lectures.

Calanus. See under Copepod.

Canadian cod (Hjort), 97.

Cardiff, 77, 109, 127.

Catch of fish, fluctuations (1906-20), 204, 205, 206, 207.

Catfish, 14, 199, 204, 205.

Clark, R. S., 75, 146, 182.

on hake, 123, 125.

on lemon sole, 144 .

on whiting, 140 .

Cladocera. See Water fleas.

Classification of fishes (Hjort's), 203-6. 
Cligny, M., 184.

Closure of fishing gromnds, 201. Sce War.

Coalfish, 14, 77, 99-102, 199, 204, 205. catch of, 99, 100, 205.

eggs, 100, 207.

fry, drift of in Tceland, 101.

life-history of, 100-2.

Cod, 14, 87-98, 199, 204, 205.

catch of, 87, 88, 89, 205.

eggs, $89,90,207$; salted in Lofoten Islands, 95.

fisheries, Canadian (Hjort), 97.

fry, drift of, in Iceland, 101.

and haddock and herring dependent on similar conditions, 16.

life-history of, 89-92.

Conger, 14, 199, 206.

('ongress, International Fishery (1908), 67.

Copepods, 15, 25, 68, 69, 74, 125, 136 , $141,146,160,182,185,193,194$, 196.

eggs, 146, 182, 194 .

as cod food, 95, 96.

food of baby fish, 193, \&c.

life-history of, 193.

'Coral' bottom, 124.

Cost of production.

great increase in, 19, 202.

research can diminish, 183, 201, 202, 203.

Council, International, $21,58,59,60$, $61,84,94,100 n ., 126,127,163$, $167,178,179$.

Cowan, Mrs., herring work, $162 n$., 168 , 169-76. See also Storrow.

C'ullercoats Laboratory, 105, 106, 140. I48, 149.

co-operation with fishing industry, $170,172$.

Cunningham, .T. T., 74, 145, 146, 149.

Currents :

North Atlantic, 188.

North Sea, 124, 191, 192

Curzon, C., 112.

Dabs, 14, 199, 204, 205.

Dahl Knut, 24, $173 n$.

Damas, D.

on coalfish, 102.

on cod, $95,96$.

on ropepods, 193.

Danes, researches of, $21,22,24,42,48$. $91,94,104$.

l)anish:

experts on size limits (plaice), ,58, 59 . halibut researches, 104.

Dannevig, H., 66, 68, 137.

Dantan, L., 67.
Day, Francis (plates from), 72,80 , $100,120,128,136,144$.

'Dead Men's Fingers', 124.

'Deep Water' fishes, 204.

Diatoms, 25, 96, 167, 192, 193, 196, 197.

Dogfish, 14, 130, 199, 206.

Donnison, F., 28, 56 .

Doughty, Sir G., 56.

Douglas, Capt. R., 43. on transplantation, $46,47,48$.

Drechsel, Commodore G. F., 58, 59.

Drifter Fleet :

catches surface fish, 17 .

composition of, 154 .

importance of steam and motor vessels, 154.

migratory, 17.

movements of, 153.

Duthie, Mr., 104.

Dutch experts on size limits, 59.

Eggs of fishes : coalfish, $100 \mathrm{n.,} 207$.

cod, $89,95,20 \%$.

- comparative size of, 207 .

copepods, 146, 182. 194.

haddock, 78, 207.

hake, 124, 207.

halibut, 104, 207.

herring, 156-62, 207 .

lemon soles, $145,207$.

ling, 136, 207.

mackerel,.181, 207.

plaice, 34, 35, 207.

skates, 131, 132, 207.

soles, 73, 74, 207.

turbot, 66, 207.

whiting, 140, 207.

Ehrenbaum, E., 145.

Engines (marine), research on. necessary, 202.

Entomostraca, 194.

Evadne, 182, 194. See Water Fleas.

Ewart, Mr., 162.

Export of herrings, 154.

Eyemouth, 152.

Fabre-Domergue, M., 66, 67, 74, 126.

'False coral', 124.

Fishery Board for Scotland, 7, 141. $147,149,157,162,198$, \&s.

Fishes, commercial, fluctuations in catch of (statistics), 204, 205,206 .

Fish eggs, 207. See Eggs.

Fishing-grounds :

Barra Head, 120.

Barents Sea, 18, 19, 33, 77, 84, 113, $199,200,201$.

Biscay, 18, 19, 108, 11], 113, 120, $122,133,199,200,201$. 
Fishing.grounds (continued) :

Bristol Channel, 18, 19, 33, 65, 72, 108, 143, 199, 200, 201.

Canadian, 77.

English Channel, 65, 69, 72, 73, 113, $114,116,117,122,133,138,141$, $143,199,200,201$.

Faeroe lslands, $17,19,33,77,81$, $90,93,94,100,103,113,135,136$, $137,143,199,200,201$.

Flannan Islands, 121.

Greenland, 105.

Iceland, 18, 19, 33, 42, 77, 81, 88, $90-4,100-4,135,136,137,143$, $199,200,201$.

Ireland, south of, 18, 19, 20, 22, 33 , $65,100,108,110,111,112,113$, $115,117,123,199,200$; west. ward of, $18,19,20,108,110$. $111,113,118,120,135,199$. $200,201$.

Irish Sea, 18, 19, 33, 54, 65, 72, 73, 108, 138, 199, 200, 201.

Kattegat, 113, 123.

Mediterranean, 117, 122.

Moray Firth, 117, 123.

New England, 90.

Newfoundland, 94.

North Sea, 17, 19, 24, 32-4, 37, 40$5,47-50,51,55-64,65,66,72,73$, $77,81,82,85,86,88,89,90,93$, $94,100,103,108,118,134,135$, $138,140,141,143,145,147,199$, 200,201 .

Northern portion distinguished, $17,19,33,51-3,88,89,100,113$, $135,139$.

Southern portion distinguished, $17,19,33,39,51-3,72,88,89,92$, $100,113,135,139$.

'Northern' (or 'Norwegian' or 'Norse ') Sea, 84, 90, 92, 94, 97, $101,140,144$.

Orkneys, 113.

Portugal and Morocco, 18, 19, 108, $111,113,120,122,133,199$, $200,201$.

Rockall, 18, 19, 103, 113, 135, 199, $200,201$.

St. Kilda, $120,121$.

Scotland, north of, 18, 19, 33, 100, $118,123,135,199,200$; westward of, $18,19,20,33,65,77,81$, $93,94,100,103,108,110,111$, $113,118,121,123,135,136,143$, $199,200,201$.

Shetland, 18, 19, 113, 124.

Skagerrak, 85, 88, 90, 113, 118, 123, $136,145$.

Stornoway, 118.
Fishing-grounds, herring :

Baltic (Scania), 154.

Danish, 155.

England; East coast, 152, 153, 154, $163,169,173,175,176,177$; South coast, 152, 153: West coast, 152,153 .

fair Isle, 172.

Ireland, 154.

Norwegian, 163, 164-8, 179.

Orkney, 152, 172, $176,177$.

Scotland: North and East coast, $152,153,155,163,172,175,177$; West coast, $152,153,155,172$. $173,175,176$.

Shetland, 152, 172, 173, 176. 177.

Sule Skerry, 176.

Swedish (Bohuslan), 154.

Fish Trades Gazette, assists herring research, 172.

Flagellates, 160.

Flat fishes: 'large mouthed', 68.

'left handed' and 'right handed', 36.

Fleetwood, 65, 70, 71, 76, 88, 99, 103, $109,127,128,134$.

Fluctuations in catch of fish, 203, 20:. 205, 206. See also ' Over-fishing'. coalfish, 205.

cod, 93, 94, 95, 96, 205.

haddock, 77, 81, 82, 205.

hake, 109, 110, 111, 206.

halibut, 205.

herring, 154, 155 .

lemon soles, $147,205$.

ling, 134, 205.

mackerel, 182, 185.

plaice, $40,20 \tilde{\text {. }}$.

skates, 128, 206.

soles, 72, 206.

turbot, 66, 206.

whiting, 139, 205.

Fluctuations in stock of 'small game', $39,94-6,142$.

Forecasts of the fish harvest a possibility, $63,64,96,160,184,185$, $196,197,203$.

Forestry, analogy of, and Fisheries, 125.

Fowler, G. H., 7.

Fraserburgh, herring landings, $15 \%$.

French researches, $21,22,24,66,67$. $68,69,70-3,94,108,112,113$, $114,115,124,126$.

Fried fish shops, 42,58 n., 109.

Fry : see Baby fish.

Fulton, T. Wemyss, 59, 66, 68, 70 , $79,141,151,154,160,161,162, \& c$.

Gardiner, J. Stanley, 7, 190. 
Garstang, W., 7, 44, 45. 48, 49, 50, 55, $80,85,184$.

Gastropods (snails), 15, 25, 160, 194.

Germany, fear of, 50 .

German cod researches, 94 .

Goldseeker, S.S., 94.

Goode, Browne, 184.

Gourret, P., 75, 117, 133.

Gran, H. H., on copepods, 193.

Green, Neal, 50.

Greenland halibut, 105 .

Grimsby, 32, 53, 65, 70, 71, 76, 88, 99, $103,128,138,144,152,180$.

Grounds, fishing: see Fishing-grounds. Gurnard, 14, 118, 199, 206.

Haddock, 14, 76-86, 114, 119, 199, 205.

catch of, 76,77 .

decline in eatch (1906-13), 80.

disappearance (1789), 77, 78.

disappearance from Cornwall (1870), 78.

eggs, 78, 207.

fluctuations governed by same factors as cod and herring, 16 .

fluctuations in catch, 81 .

life-history, $78,79,80,83,84-6$.

revival (1919-20), 82, 205.

1902 , 1903, 'bad spawning years', 85.

1904, a 'good spawning year', 85 .

Hake, 14, 108-27, 199, 206.

catch of, 108. 109, 110. I11.

eggs, 124, 207.

fluctuations, 109, 110, 111, 205.

larvae, 125, 126 ; their food. 125

life-history, 122-7.

migrations, 114, 115.

'mushiness', 118, 119.

North Sea, 113.

Halibut, 14, 36, 103-7, 199, 205.

catch of, 103, 104 .

earstones, 105, 106 .

eggs, 105, 206.

growth of, 106.

life-history, 104-7.

Hammam, M., 59.

Hartlepool, 77, 88, 144, 153.

Hatcheries, Sea-fish

information furnished from, cod eggs (Woodshole, U.S.A.), 89, $90,97,98,207$;

haddock eggs (Boothbay, U.S.A.), 79,207 ;

herring eggs (U.S.A.), 156, 207 ;

mackerel eggs (Woodshole), 181, 182, 207 ;

plaice eggs (Trondjhem), 3: ;

turbot fry (J)unbar), 66 .
Hatcheries, Sea-fish (continued) :

need for large-scale experiments in, 145.

- Hatching, influence of temperature in, $34,68,78,90,97,100,125,136$, $140,145,156,181$.

Havelock, E. H., 7.

Hefford, A. E., 8, 38.

Heincke, F., 44, 59, 79, 163.

Helland Hansen, B., 112, 186-8, 191.

Hellyer, C., 27, 56, 122.

Herrings, 161-79.

catch, $161,162$.

development of fry, 159-62.

disappearances of, 154,155 .

eggs and fry, 156, 160, 207.

export of, 154 .

'Fjord' herring, 157, 158, 164.

harvest, times of, 153 .

infant mortality, 165 .

landings, 14, 124, 151-79, 124.

larvae, food of, 159 .

life-history, 156-77.

races of herring : 'Dogger' Herring, 163; 'Shetland', 162; 'Norse', 163.

scale reading, $163,165,166,167$, $168,169-77$.

Scottish fishermen on, $176,177$.

Spawning, 156-8.

temperature affects spawning, 156 .

trawled herrings, 117, 152, 177.

Herrings, cod, and haddock stocks influenced by same factors, 16 .

Hérubel, A., 64, 109, 124, 144.

Hind, Mr., 184.

Hjort, J., 7, 13, 15, 18, 21, 22, 24, 31, $66,73,78,79,83,84-6,90,181$, $186-8,203,206$.

on Canadian herrings, 178.

coalfish, 100, 102.

cod, 90, 94-8.

haddock, 84-6.

hake, $112,124,126$.

halibut, 104.

herring races, 163.

herring scales, 163, 164, 165-9, 173-5.

lemon soles, 144.

ling, 135 .

North Sea currents, 191.

skates, 129, 130.

'Small Game', 189.

whiting, 139, 140, 141, 142.

Hjort's classification of fishes, 202-6.

Holt, E. W. L., 59, 66, 68, 78, 123, 126 , $145,147$.

Hull, 32, 53, 70, 76, 88, 99, 103, 109, $128,134,138,144,152$.

Ice, polar, effect on tisheries, 1.4, 90. 
Iceland, maps of, 42, 101 .

fishing-grounds: sce Fishinggrounds.

Immature plaice :

result of catcling, 44,45 .

where caught, 53.

International Council, 21, 41, 44, 58, $59,60,61,67,126,143,163,178$, 179. See Council.

International Fishery Congress (1908), 67.

Infant Mortality: heavy, the rule among fishes, $21,22,39,43,64$; cod, $95,96,97$; haddock, 85,86 ; herrings, 165.

Irekend : laboratory needed on north or west coast, 133 .

mackerel fishery, 180, 181.

Jackson, R., S.

Japanese on spawning herring, 157 .

Jenkins, J. T., 7, 54, 80, 157, \&..

Johansen, A. C., 58, 59, 64.

Johnstone, James, 7, 35, 54, 130, 131. 161, \&c.

Joubin, Professor, 59

Kyle, H. M., 143.

'Large-mouthed' flat fish : soles, brill, dabs, megrims, plaice, and turbot, 68

Larvae: see Baby fish.

Larval fish : see Baby tish.

Lea, Einar :

on herring scales, 164-8.

on infant mortality among herrings, 178.

on predominance of 1904 and 1912 broods of herrings, 178.

Lebour, M. V.. 7, 68, 69, 74, 75, 125, $136.140,141,159,160,182,192-7$. food of baby tish, 192-7.

brill, 68 .

dabs, 68.

liake, 125 .

herring, 159,160 .

lemon soles. 146.

ling, 136.

mackerel, 182.

plaice, 68 .

soles, $68,74,75$.

turbot, 68,69 .

whiting, $140,141$.

Le Danois, Dr., on hake, 108, 112-15, 122-7.

Lemon soles (Pleuronectes microcephalus), 14, 36, 143-50, 199, 205. catch of, 143,144 .

decline in catch (post-war), 19, 204.
Lemon soles (continued) :

eggs, 145, 206.

fluctuations, 147, 148, 204.

life-history, 144-6.

surface life prolonged, 147.

Life-history :

coalfish, 100-2.

cod, 89-92.

copepods, 193.

haddock, 84-6.

hake, 122-7.

halibut, 104-6.

herring, 156-77.

lemon soles, 144-6.

ling, 136, 137 .

mackerel, 181, 182 .

plaice, 3t-9.

soles, 73-5.

turbot, 66-9.

whiting, 139-41.

Life, marine, interdependence of all forms, $185,196$.

Ling, 14, 118, 120, 134-7, 198, 204.

catch of, 134,135 .

decline in catch, 135 .

fluctuations, 134, 205.

life-history, $136,137$.

and mackerel, 184, 185.

Ling (blue) (Molva byrkelange), 135.

Ling, Southern (Molva elongatr,) 118 , 135.

Liverpool, 88.

London, fish landed direct in (chiefly from Hull trawlers), 32, 65, 76, 88. $138,114$.

Lowestoft, $32,65,71,76,88,128,138$, $144,152,180$.

Mackerel, 14, 114, 124, 132, 180-5, 198.

'caprices' of, 182-4.

catch of, 180-1.

egos of, 181, 206 .

fluctuations in cateh, $152-t$

larvae, 181.

life-history, 181, 182.

and sunshine, 196, 197.

Mackie, R., 104.

MeIntosh, IV. C., 7, 40, 70, 73, 74, 80, $102,104,136,139,145,146, \& c$.

McNaughton, J. L., 29.

Macrurus (abyssal fish), 112.

Malard, A. E., 67.

Man, Isle of, herring landings, 152.

Marine Biological Association, 34, 48, $49,50,66,68,73,74,75,136,140$, $141,144,146,147,159,160,181$, $182,184,192,197$.

Marine engines, rescarch on, necessary, 201. 
Marking experiments, 42.

Marston, R. B., 8.

Masterman, A. T., 7, 58, 73, 80, \&c. See also MeIntosh for British Marine Food Fishes.

Matthews, Mr., 162.

Moad, A. D., 69.

'Medium Water' fishes, 204.

Neek, A., 7, 37, 74, 78, 79, 125, 132, $136,137,144,146,147,168,171$, 184.

Mlegrims (Zengopterus megastoma), 14, 36, 120, 199, 206.

Meyer, F. (herring experiments), 165.

Michae! Sars, S.S., 15, 130, 181, 188, 191.

I. and S. Miles, S.T., 64.

Milford Haven, 71, 77, 88, 109, 127, $128,134,180$.

Millport Laboratory (Buteshire), utility of, 133.

Minchin, C. O., 129, J30.

Jitchell, J. M., on herring eggs (1864), 157.

Mlonks (Lophius piscatorius), 14, 120 , 199, 206.

Montrose, 32, 77.

Moody, G. J., 7, 29.

Mora (abyssal fish), 112.

Morley, C. C., 11.6, 117, 159, 177.

Nansen, F., 24.

Neale, H. H., 120, 121.

Neale, J. J., 118.

Newhaven, 152.

Newfoundland, Hjort's researches on cod, 94.

Newlyn, 180

Nicholas Dean, S.T., 188.

North Sea, 'areas' of, 41, 51, 52, 53. See under Fishing-grouncls

'Northern' fish and animals, 20, 186$92,198,203,204,205$.

southern boundary of their Atlantic territory, 186.

North Shields, 76, 88, 99, 103, 128, $134,138,144,152,180$.

harbour improvements needed, 153.

Norwegian research, $15,21,22,24,73$, $83,84-6,94,156,178,179$. See Hjort.

\section{Ucean Research :}

achievements, 24.

international partition of work, 21 . utility of, $25,70,86,93,98,158,203$. See also Forecasts.

Oithona, S.Y., 123, 192.

Orkney herring landings, 152.

Urtun, J. 11., 181, 185.
Otoliths (or earstones), 22.

Over-fishing, probably not the main factor influencing fluctuations, 14, 22, 178, 201, 202, 207.

cod, herring, and coalfish, 93.

cod, $89,93,94-8$.

haddock, 77, 78, 79, 80, sı, 8:2, 83, $85,86$.

hake, 109-14, 116.

herring, 154, 155, 156, 1601, 165.) 1666, $178,179$.

lemon soles, $147,150$.

ling, 135 .

mackerel, 181, 182, 183, 184, 196, 197.

plaice, $39,44,64 n$.

skates, 129, 132.

soles, 72.

turbot, 66,69 .

whiting, $139,142$.

Oxford University support to M. B.A., 70.

Padstow, 71.

Pan-Pacific C'onference on tishery statistics, 27.

Patterson, A. H., 132, $18:$.

Peridinians, 160.

Peterhead, 152.

Petersen, C. G. J., 39, 48, 86, 147.

Physico-chemistry, term not understood by laymen, 124 .

Piel Laboratory, (Lancs.) utility of, $70,133$.

Pilchard, 14, 198.

Plaice, 14, 31-64, 199, 205.

eatch, $31,32$.

decline in eateh of large fish (prewar), $42,43$.

eggs, 34,35 .

fluctuations, 40, 205.

grounds, 33 ; closure of, 53 ; com. parative productivity of, 51, 5:.

immature, result of catching, 44,45 ; where caught, 53.

life-history : eggs, 39; fecdinggrounds, 39 ; fry, 36 : larvae, 34 , 36 ; maturity, 38 ; migrations, early, 37 ; movements of adults, 39 ; nurseries, 37 ; spawning, 34. ports, 32 .

size limits, 56-8.

small plaice, 41 , \&c

stock of, $40-5$.

transplantation, $46,47,48,49,50$.

war, alleged effect on stock, 62-4.

Plymouth Laboratory, limitations of,

195. See Marine Biological Association

Plymouth, port of, 77, 109, 15:.

Podon, 152, 194. Sce Water Fleas. 
Polar ice, 14, 85.

Pollock, 120.

P'opular lectures and publications, need for, $13,16,22,24,25,45,61$, $70,75,83,96,97,106,107,121$, $122,124,126,127,132,133,142$, $167,171,177,183,192,195,197$, 203.

Population of sea, immense variations in, from year to year, $21,22,39$, $40,43,64 n ., 80,85,86,94-7,165$.

Portuguese researches, 116, 126.

Post-war statistics, 198-206.

Potter, J., 48.

'Practical' research-a heresy recanted, 195.

Preservatives for fish, researeh needed to discover, 202.

Prince, E. E., 70.

Productivity, comparative, of fishinggrounds, 19, 200, 201.

Raffiaele, Dr., 122, 125.

Raiidae, 129; species of, 129, 130, 132. See Skates.

Ramsgate, 32, 71 .

Rays : see Skates.

Redeke, H. C., 59.

'Regions', fishing, 16, 17, 18, 19, 20, \&c. See Fishing-grounds.

Rees, H. E., 115, 118-20.

Research, industrial need for, 202.

Research, Ocean :

achievements of, 24 .

international appointment of work, 21.

not ' unpractical', 70 .

utility of, $25,70,86,93,98,203$.

Rhode Island Hatchery, 69.

Robertson, J. A., 8.

Royal Society, transactions, 77.

Russell, E. S., 59, 78, 80, 81.

Salmon, 132, 185.

Sand, whitings apparently eating, 142 .

Sandhoppers (amphipods), 15, 141, 142,196 (ill.).

fluctuations among, 142 .

Sar's, MI., 90, 95.

Scale-reading :

explained, 21, 22.

coalfish, 23, 101, 102.

cod, 92 .

haddock, 84-6.

herring, 153-77.

Scarborough, 77, 88; 144.

Schmidt, J., 2t, 79, 91, 104, 122, 125, $126,136,137$.

Science and business: see 'Business' and 'Science', und l'opular lectures.
Scott, Andrew, 74, 156, 182, 192, 194, 196.

Scruff : see under Coral.

Sea-houses, 153.

Seine net better than trawls for re. search work, 165, 169.

'Shallow-water fishes', 203.

Shetland, herrings landed at, 1.52.

Shetland herring (race of), 16:2.

Shrimp trawling, 44, 54, 55 .

Sim, G., 130.

Size of fish no guide to age, 149,171 , 175.

limits for plaice, $56-8$.

Skates, 14, 128-33, 199, 206.

catch of, 128 .

eggs, 132.

fluctuations, 129,205 .

life-history, 130-3.

species of, 129, 130, 132.

'Small Game' of the Sea, 186-97.

fluctuations in abundance, 39, 61, 142.

Small plaice, 41,42 .

Small-plaice grounds, 51.

attempts to close, 52 .

effect of closure on, 53 .

map of, 57.

soles on, 57.

Sinails (gastropods), 15, 2.5, 160, 19.4.

Soles, 14, 36, 71-5, 118, 199, 206.

catch, 71, 205.

eggs, 73 .

fluctuations, 72, 206 .

life-history, 73 .

Soles, 'French' (Solea lascuris), 75.

'thick back' (Soleu vurieguta), 74, 75 .

Spawning, turbot prevented from, by over-feeding, 68.

Spawning years ('good' and 'bad '), $39,69,79,80,85,90,94-7,111$, $160,165-7,170,192,193$.

Sprats, 14, 199.

form whitebait in August (Menai Strait), 162.

form winter whitebait in Thames, 162.

Statistics :

business men on, 27-30.

must be compulsory, $27,28,29$.

must be uniform, 26,27 .

need for greater accuracy, 26.

post-war, 198-206.

Stornoway, herrings landed at, 152.

Storrow, B., 8.

on halibut, 105, 106.

herrings, 104 (ill.), 168-76.

lemon soles, $148,149$.

whiting, 140 . 


\section{Sunshine}

affects abundance of mackerel, 197. affects abundance of sea plants, 196, 197.

affects supply of copepods, 196.

Swansea, 77, 109, 127.

Swedish research, 21, 22, 24, \&c.

\section{Talisman, S.S., 124.}

Temora, $69,74,141,146$. See Cope pods.

Temperature :

affects hatching, $34,68,78,90,97$, $100,125,136,140,145,156,181$. effect of, $73,90,97,124,125,159$, 186-92.

uniform at 300 fathoms, 112 .

Temperature charts :

North Atlantic at 50 fathoms, 187.

North Atlantic Surface, 189.

North Sea, 190.

Tennant, H. J., his Fishery Committee (1908), 27, 28, 29, 43, 44, 48, 56, $116-18,158,185$.

Thor, S.S., 91, 104.

T'orsk, 14, 112, 199, 204, 205.

Transplantation of plaice, 46-50.

Travailleur, S.S., 124.

Trawler fleet :

catches bottom fish, 17 .

component 'squadrons' of, 17, 18, 19.

cost of trawling, 19.

Trawling below 300 fathoms (Hjort), 112.

for herrings, $117,177$.

Trondjhem, 39.

Turbot, 14, 36, 65-70, 1]8, 199, 206. eatch of, 65,66 .

eggs, 66, 207.

feeding newly-hatched larvae, the secret of rearing, 69.

hatching and rearing, 66-9.

life-history, 66-9.

spawners, over-feeding of, will prevent from breeding, 68 . spawning, 68.

Uniform statistics, need for, 26, 27.
United States Bureau of Fisheries, 67 , $78,79,89,95,97,105,119,165$, 181.

Unity of all fishing interests, $16,185$.

Vivian, J., 28, 56.

von Bayer, H., 89, 207.

Walker, Dr., work on herring eggs (1803), 157.

War:

alleged effect on fish stock, 86, 198207.

alleged effect on plaice stock, 62-4.

Ward, R. C., 118.

Water fleas (Cladocera), 15, 136, 182, 194. See Podon and Evadne.

Whales :

compared with herrings, 160 .

their method of feeding, 160 .

'finner', live on copepods, 193.

Whitebait, 162.

Whitchet, Mr., 184.

Whiting, 14, 138-42, 199, 205.

catch of, 138, 139.

eggs, 140.

fluctuations, 139, 205.

larvae (their food), 140, 141.

life-history, 139-42.

movements determined by foodsupply, 142.

Wick, herring landings at, 152.

Wickford hatchery (U.S.A.), 69.

Williamson, H. C., 147, 149.

Witches (Pleuronectes cynoglossus), 14, $36,199,205$.

Woodshole Fish Hatchery (U.S.A.), $89,97$.

Yarmouth :

defective harbour acerommodation at, 153.

herring landings, 15\%.

mackerel fishing, 180-3.

Yolk-sac, baby fish feed before absorp. tion of, $36,68,69,74,146,160$, $192,193,194,195$. 



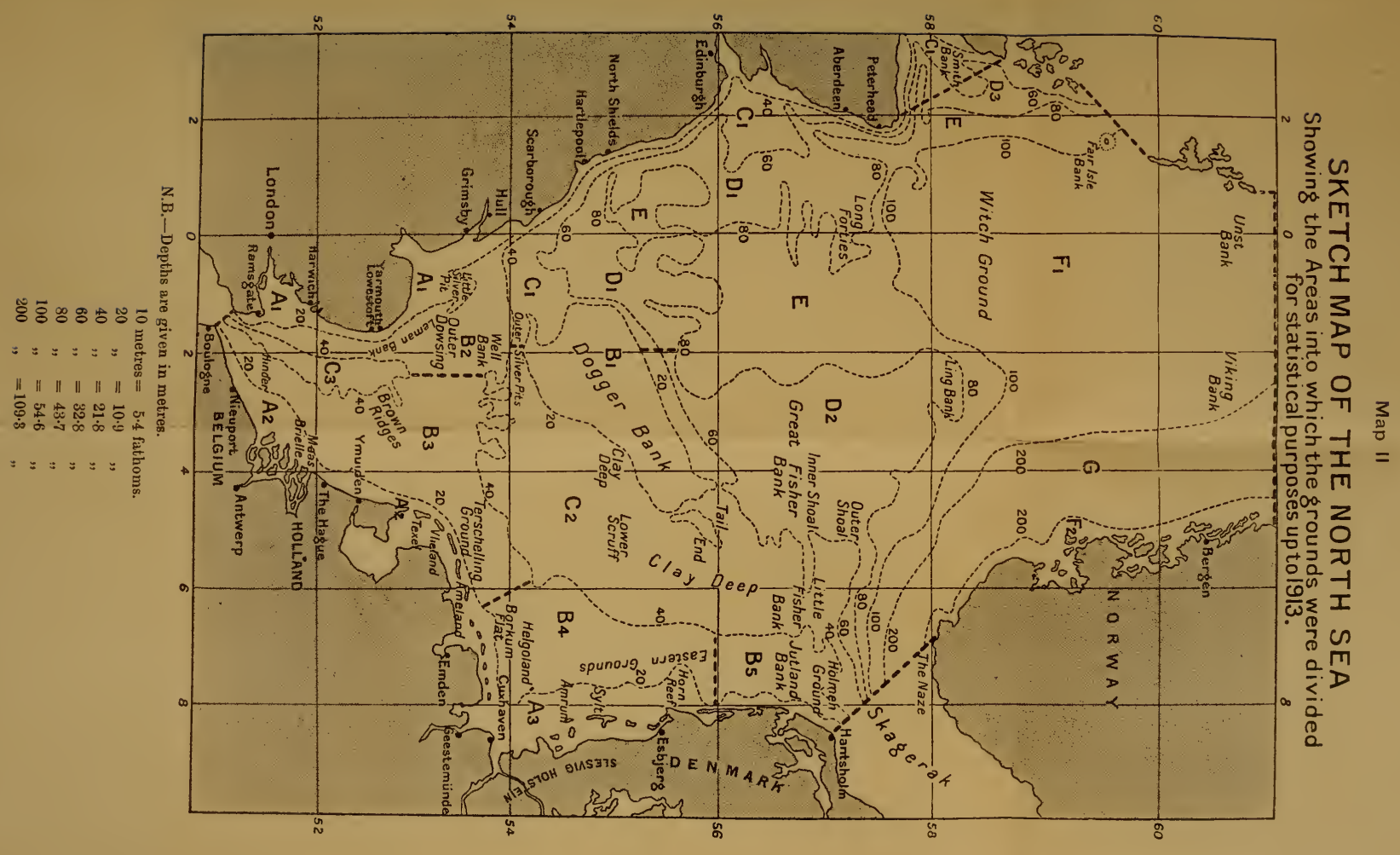



Map III

\section{SKE'TCH MAP OF THE NOR'THERN HERRING GROUNDS}

A. From Shiant Islands to Stoer Head. 'Matties' in June, July, and August; 'Spawning Herrings' in September ; 'Full Herrings' in winter.

B. From Rona Head to Loch Ewe. 'Matties' in August ; January and February, 'Full Herrings'; March, 'Spawning Herrings'.

C. From Rodel to Kebock Head. 'Matties' in July, August, and September.

D. From Tiumpan Head to Barvas. ' Matties' in June, July, August; Spawners in September; Full Herrings in January and February ; Spawners in March.

E. From Stoer Head to Strathy Point. Full Herrings in January and February ; Spawners in March.

F. West of Orkney Grounds. Large Matties in May, June, July.

G Fair Isle Grounds. Fulls and Matfulls in July and August; Spents at end of August ; very small tender fish in summer.

No ripe spawning fish. Small

Burra Half Ground. immature Herrings May and

J. From Ronas Voe to early June; bigger fish to midGloup Holme. dle of July, when herrings dis. appear.

K. From Romna Stacks to Flugga. 'Lafulls' and 'Matfulls' in February ; Spent Herrings during March and sometimes in April.

L. Unst and Fetlar Summer feeding shoals, joined by Grounds.

M. WhalseyGrounds. Herrings in June which do not keep

N. Bressay Grouns. well. The shoals contain many

young fish.

0. Copinshay Grounds. Small Matties in June ; Fulls and Matfulls in July and August ; generally 'tender' fish.

P. Auskcrry Grounds. Small Matties in June; Full Herrings in July and August: Spent Herrings end of August.

Q. East of Wick and Peterhead Grounds. Spawning Her-

R. rings in Autumn.

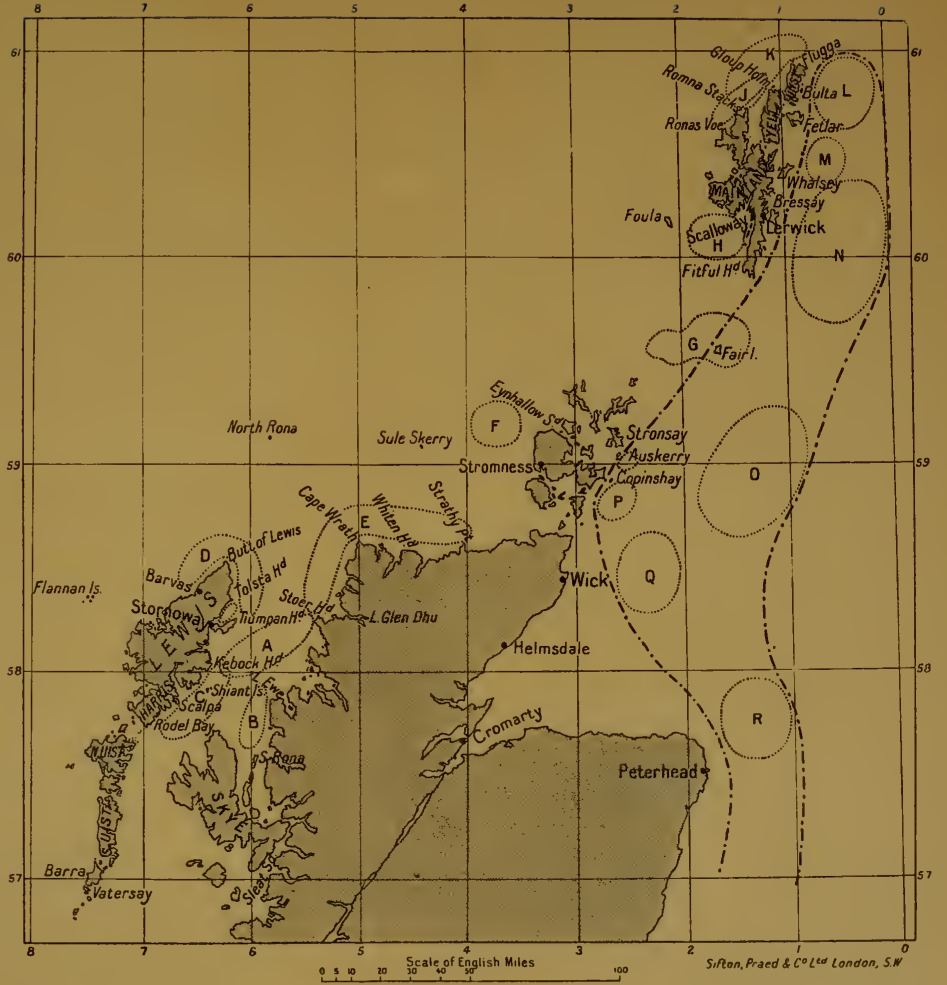

(After Storrow.) 




18

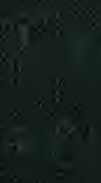

